Tese de Doutorado

QUÍMICA SUPRAMOLECULAR DE TETRAPIRIDILPORFIRINAS

ASSOCIADAS A COMPLEXOS DE PLATINA(II)

Autor: Jeferson André Naue

Orientador: Prof. Dr. Henrique Eisi Toma

maio de 2006 


\section{Química Supramolecular de Tetrapiridilporfirinas Associadas a Complexos de Platina(II)}

Tese apresentada ao Instituto de Química da

Universidade de São Paulo para obtenção do título de Doutor em Química.

Área de Concentração: Química Inorgânica Orientador: Prof. Dr. Henrique Eisi Toma

São Paulo

2006 
Ficha Catalográfica

Elaborada pela Divisão de Biblioteca e

Documentação do Conjunto das Químicas da USP.

Naue, Jeferson André

N295q Química supramolecular de tetrapiridilporfirinas associadas a complexos de platina(II) / Jeferson André Naue. -- São Paulo, 2006.

$150 \mathrm{p}$.

Tese (doutorado) - Instituto de Química da Universidade de São Paulo. Departamento de Química Fundamental.

Orientador: Toma, Henrique Eisi

1. Química supramolecular 2. Química de coordenação: Química inorgânica 3. Complexos de platina 4. Porfirina I. T. II. Toma, Henrique Eisi, orientador. 


\section{"Química supramolecular de tetrapiridilporfirinas associadas a complexos de platina(II)"}

\section{JEFERSON ANDRÉ NAUE}

Tese de Doutorado submetida ao Instituto de Química da Universidade de São Paulo como parte dos requisitos necessários à obtenção do grau de Doutor em Química - Área: Química Inorgânica.

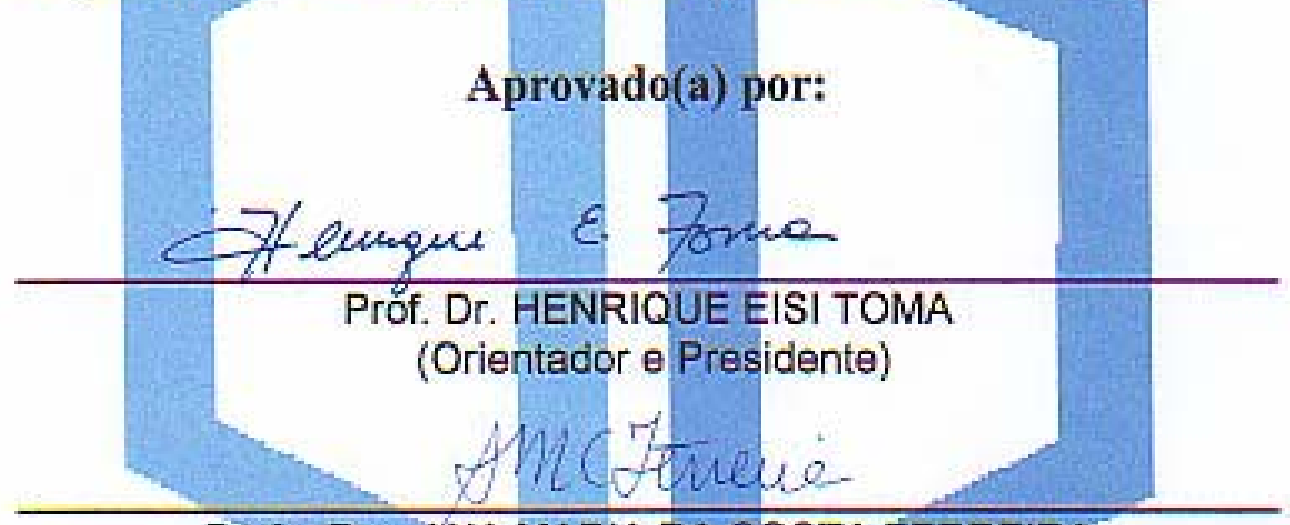

Profa, Dra. ANA MARIA DA COSTAFERREIRA

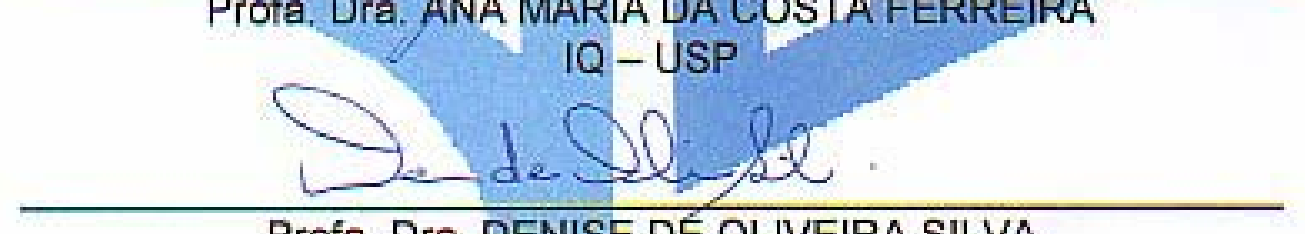

Profa. Dra. DENISE DE OLIVEIRA SILVA

IQ - USP

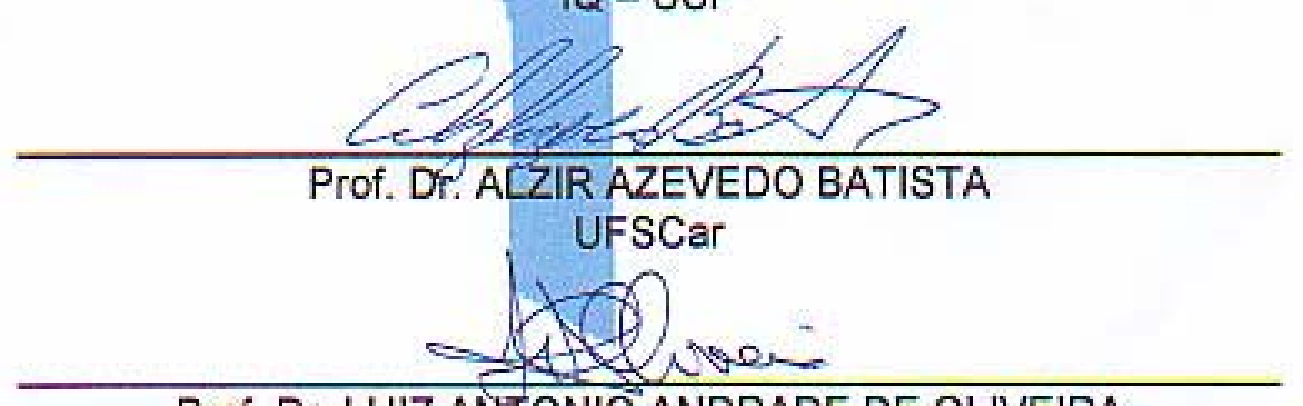

Prof. Dr. LUIZ ANTONIO ANDRADE DE OLIVEIRA

$I Q$ - UNESP - Araraquara

SÃO PAULO

18 DE MAIO 2006 
Se eu não tivesse o amor, eu nada seria....

Aos meus pais Elirio e Nilva e meus irmãos Gilmar e Maristela, pelo apoio incondicional, pelo incentivo permanente e por toda a confiança que sempre depositaram em mim.

À minha guria... Deise, pelo amor sincero que me dedica, estando ao meu lado em todos os momentos.

A uma família e esposa tão especiais como vocês dedico esta conquista. 
Ao Professor Henrique Toma meu agradecimento com a mais alta estima por ter me recebido no grupo e orientado este trabalho. Sua atitude inovadora aliada a incrível dedicação que tem pela ciência, são um verdadeiro exemplo para seus alunos. 
Antes do compromisso há hesitação, a oportunidade de recuar, uma ineficácia permanente.

Em todo o ato de iniciativa e de criação há uma verdade elementar, cujo desconhecimento destrói muitas idéias e planos esplêndidos. No momento em que nos comprometemos de fato, a Providência também age. Ocorre toda a espécie de coisa que de outro modo nunca ocorreria. Toda uma cadeia de eventos emana da decisão fazendo vir em nosso favor todo o tipo de encontros, de incidentes, de apoio material e de imprevistos, que ninguém poderia sonhar que surgiriam em seu caminho. Começa tudo que se possa fazer, ou que se sonha fazer. A ousadia traz em si o gênio, o poder e a magia. 


\section{Agradecimentos}

Ao CNPq, pela bolsa de doutorado.

Aos membros da banca por terem prestigiado este trabalho participando da defesa e pelas críticas enriquecedoras.

Ao Prof. Marcos Eberlin e a Dra. Daniela Tomazela, do Instituto de Química da Unicamp, pela medida dos espectros de massa.

À Miriam Uemi, da central analítica do IQ, pela colaboração com os espectros de RMN de platina.

Aos amigos Juliano e Sérgio pela grande força que me deram na reta final deste trabalho e pela colaboração com os dados de SPR.

Formiga e Marcelo pela colaboração com os dados de modelagem molecular e microscopia.

Ronaldo, pelas conversas sempre ricas em informação e pela revisão do texto.

Genebaldo pelo incentivo. A todos vocês agradeço principalmente pela grande amizade e companheirismo.

À Aninha pelo convívio nestes anos de laboratório e pelo suporte prestado no nosso dia-a-dia de experimentos.

Ao Prof. Koiti e a todos os colegas de diferentes gerações do LQSN como Herbert, Ildemar e Fauze, com quem tive o prazer de conviver e muito aprender nesses últimos anos.

Aos amigos de sempre Paulo Lima, Adriano Oliveira e tantos outros que eu poderia citar, mas que apenas me limito para não me estender demais, pela amizade e incentivo.

Finalmente, a todos aqueles que de alguma forma contribuíram para que esta tese se tornasse realidade, meu profundo agradecimento. 


\section{Resumo}

A preparação, caracterização e estudo de propriedades moleculares e supramoleculares de meso-tetrapiridilporfirinas modificadas com quatro complexos de cloro(bipiridina)platina(II) ligados às posições meta e para de ligantes piridínicos periféricos, foi objetivo desta tese. As supermoléculas isômeras foram isoladas no estado sólido e extensivamente caracterizados por meio de espectroscopia UV/VIS, FT-IR e RMN de 195Pt, assim como através de TGA e espectrometria de massa com ionização por spray de elétrons, ESI-MS, e técnicas de dissociação induzidas por colisão. Medidas de voltametria cíclica e de espectroeletroquímica foram realizadas para caracterizar os estados redox da porfirina central e dos complexos periféricos, mostrando uma semelhança entre as duas formas isômeras. A maior diferença, entretanto, foi observada nas suas propriedades estruturais, diagnosticadas por modelagem molecular, e refletidas na morfologia dos filmes obtida por meio de técnicas de microscopia de varredura por sonda, SPM, e através da associação com filmes de DNA, monitorada com o auxílio de técnicas de espectroscopia eletrônica e ressonância plasmônica de superfície, SPR. No último caso, o DNA foi imobilizado sobre a superfície do sensor de ouro, usando aminotióis adequados, sendo que a interação do isômero meta conduziu a uma resposta contrastante, relevando uma forte ligação com a cadeia do DNA, provavelmente nas proximidades das fendas estruturais menores desse biopolímero. A interação do isômero para com o DNA foi demasiadamente fraca para ser observada por meio de SPR. A associação molecular das porfirinas tetraplatinadas catiônicas com ftalocianinas aniônicas tetrassulfonadas conduziu à formação de pares iônicos em solução. O filme do isômero para imobilizado sobre eletrodo de carbono vítreo apresentou atividade na redução eletrocatalítica de nitrito. Os trabalhos realizados demonstraram que os novos sistemas supramoleculares derivados de porfirinas e complexos de platina proporcionam interessantes materiais híbridos inorgânico-biológicos contendo DNA e metais nobres, com potenciais aplicações em terapia fotodinâmica, sensoriamento e em dispositivos moleculares. 


\begin{abstract}
The synthesis, characterization and investigation of the molecular and supramolecular behaviour of meso-tetrapyridylporphyrins containing four chloro(bipyridine) platinum(II) complexes attached at the meta and para positions of the peripheral pyridine ligands is focused on this thesis. The isomeric supermolecules were isolated in the solid state, and extensively characterized by means of UV-visible, FT-IR and ${ }^{195} \mathrm{Pt}$ NMR spectroscopy, as well as, by TGA and electrospray spectrometry associated with collision induced techniques. Cyclic voltammetry and spectroelectrochemical measurements were performed to characterize the redox sites on the porphyrin and peripheral complexes, revealing a close similarity between the two isomeric supermolecules. Major differences were observed on their structural properties, as demonstrated by means of molecular simulations, and by the morphology of the molecular films probed by SPM techniques, and also by their association with DNA films, which was monitored by means of SPR techniques. In the last case, DNA was first immobilized onto the surface of the gold sensor, using suitable aminothiols and the interaction of the meta-isomer led to a contrasting response, exhibiting a strong binding to the DNA chain, presumably at the proximity of the minor grooves. The interaction of the para-isomer with DNA was too weak to be probed by means of the SPR technique. Molecular association of the tetraplatinum porphyrin species, with tetrasulphonated phtalocyanines, leading to ion pairs in solution, was also investigated. The molecular film of the para-isomer immobilized over glass carbon electrode has shown activity in the electrocatalytic reduction of nitrite. This work on the supramolecular porphyrin platinum species, provided new interesting approaches for generating hybrid biological-inorganic systems, containing DNA and noble metals, for sensing applications, and molecular devices.
\end{abstract}




\section{Lista de Abreviaturas, Acrônimos e Símbolos}

4-TPyP = meso-tetra(4-piridil)-21H,23H-porfirina (porfirina base-livre)

3-TPyP = meso-tetra(3-piridil)-21H,23H-porfirina (porfirina base-livre)

4-TPtTPyP = meso-tetra(4-piridil)-porfirina- tetrakis-(2,2'-bipiridina-cloro-platina(II)

3-TPtTPyP = meso-tetra(3-piridil)-porfirina- tetrakis-(2,2'-bipiridina-cloro-platina(II)

4-TPtTPyPZn= meso-tetra(4-piridil)-porfirinato de zinco(II)- tetrakis-(2,2'-bipiridina-

cloro-platina(II))

3-TPtTPyPZn= meso-tetra(3-piridil)-porfirinato de zinco(II)- tetrakis-(2,2'-bipiridinacloro-platina(II))

4- $\mathrm{TPt}($ terpy $) \mathrm{TPyP}=$ meso-tetra(4-piridil)-porfirina- tetrakis- $\left(2,2^{\prime}: 6^{\prime}, 2^{\prime \prime}{ }^{\prime}\right.$-terpiridinaplatina(II))

3-TPt(terpy) $\mathrm{TPyP}=$ meso-tetra(3-piridil)-porfirina- tetrakis- $\left(2,2^{\prime}: 6^{\prime}, 2^{\prime}{ }^{\prime \prime}\right.$-terpiridinaplatina(II))

3-TPt(dcbpy) $\mathrm{TPyP}=$ meso-tetra(4-piridil)-porfirina-tetrakis- $\left\{\left(4,4^{\prime}\right.\right.$ dicarboxil $)-2,2^{\prime}$-bipiridina-cloro-platina(II)\}

$\Phi_{e m}=$ rendimento quântico de emissão

$\tau_{\mu}=$ tempo de vida do estado excitado

$\epsilon=$ absortividade molar

$\lambda=$ comprimento de onda

$\nu_{s}=$ estiramento simétrico

$\nu_{a s}=$ estiramento assimétrico

$\delta=$ deformação no plano

$\mathrm{AFM}=$ microscopia de força atômica

$\mathrm{AT}=$ adenina-timina

bipy $=2,2^{\prime}$-bipiridina 
$\mathrm{bpm}=2,2^{\prime}$-bipirimidina

$\mathrm{CE}=$ energia de colisão

$\mathrm{COD}=1,5$-ciclooctadieno

$\mathrm{CT}=$ transferência de carga

CT-DNA $=$ calf-thymus DNA

D-C-A = doador-cromóforo-aceptor

$\mathrm{CuPcTS}=3,4^{\prime}, 4^{\prime \prime}, 4^{\prime \prime}{ }^{\prime}$ '-tetrassulfonatoftalocianinato de cobre(II)

dcbpy $=\left(4,4^{\prime}\right.$-dicarboxil $)-2,2^{\prime}$-bipiridina

$\mathrm{DCM}=$ diclorometano

$\mathrm{DFT}=$ teoria do funcional de densidade

$\mathrm{DMF}=\mathrm{N}, \mathrm{N}^{\prime}$-dimetilformamida

DMSO $=$ dimetilsulfóxido

$\operatorname{dpp}=2,3$-bis $(2$-piridil)pirazina

DPyDPhP $=$ meso-di(piridil)-di(fenil)porfirina base-livre

$\mathrm{dTG}=$ Primeira derivada da curva termogravimétrica

ESI-MS = espectrometria de massa com ionização por spray de elétrons

$\mathrm{GC}=$ guanina-citosina

$\mathrm{HOMO}=$ orbital molecular ocupado de maior energia

IPCE $=$ eficiência de conversão de fotocorrente incidente

$\mathrm{IV}=$ infravermelho

LDL = lipoproteínas de baixa densidade

LUMO = orbital molecular não-ocupado de menor energia

$\mathrm{MeCN}=$ acetonitrila

$\mathrm{MeOH}=$ metanol

MLCT $=$ transferência de carga metal-ligante

MTPyP $=$ meso-tetra(4-piridil)metaloporfirina

ORTEP $=$ Oak Ridge Thermal Ellipsoid Plot - plotagem das elipsóides térmicas $\mathrm{PDT}=$ terapia fotodinâmica 
phen $=1,10$-fenantrolina

$\mathrm{PhIO}=$ iodosilbenzeno, $\mathrm{C}_{6} \mathrm{H}_{5} \mathrm{IO}$

$\mathrm{PSI}=$ fotossistema I

PSII $=$ fotossistema II

py $=$ piridina

RMN = ressonância magnética nuclear

$\mathrm{SPM}=$ microscopia de varredura por sonda

$\mathrm{SPR}=$ ressonância plasmônica de superfície

t.a. = temperatura ambiente

TCP $=$ tetrapiridilporfirina-tetracluster de rutênio

$\mathrm{TE}=$ transferência de energia

Tel $=$ transferência de elétrons

terpy ou tpy $=2,2^{\prime}: 6^{\prime}, 2^{\prime \prime}{ }^{\prime}$-terpiridina

$\mathrm{TFE}=2,2,2$-trifluoretanol

$\mathrm{TPyPz}=\operatorname{tetra}(4$-piridil)porfirazina

tris $=$ tris[hidroximetil]aminometano

$\mathrm{TRP}=$ tetrapiridilporfirina-tetrarutenada

$\mathrm{UV} / \mathrm{VIS}=$ ultravioleta/visível

$\mathrm{VC}=$ voltametria cíclica

ZnTRu(bipy)P = tetrapiridilporfirinato de zinco(II) tetrarutenada

ZnTPPS $=$ meso-tetra(4-sulfonatofenil)porfirinato de zinco(II) 


\section{Sumário}

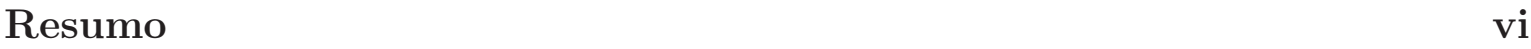

Abstract vii

Abreviaturas, Acrônimos e Símbolos viii

1 Introdução 1

1.1 Química Supramolecular e Nanotecnologia . . . . . . . . . . . . . 1

1.2 Compostos de Coordenação Supramoleculares . . . . . . . . . . . . . . 8

1.2.1 Fotossíntese Artificial . . . . . . . . . . . . . . . 8

1.2.2 Aspectos Conceituais e Sintéticos . . . . . . . . . . . . . . . . . 14

1.3 Sistemas Supramoleculares de Porfirinas . . . . . . . . . . . . . . . 16

1.3.1 Complexos com Rutênio . . . . . . . . . . . . . . . . . . 17

1.3.2 Pares Iônicos Supramoleculares . . . . . . . . . . . . . . . . . . 22

1.4 Complexos Diimínicos de Platina . . . . . . . . . . . . . . . 26

1.4.1 Interação com Biomoléculas . . . . . . . . . . . . . . . . 26

1.4.2 Propriedades Espectroscópicas e Fotofísicas . . . . . . . . . . . . 29

1.4.3 Sistemas Supramoleculares . . . . . . . . . . . . . . . . . 33

1.5 Complexos Porfirínicos de Platina . . . . . . . . . . . . . . . 35

1.5.1 Arranjos Quadrado Moleculares . . . . . . . . . . . . . . . 35

1.5.2 Atividade Biológica . . . . . . . . . . . . . . . . . . 39

1.6 Objetivos . . . . . . . . . . . . . . . . . . . . 42 
2 Parte Experimental $\quad 45$

2.1 Sínteses . . . . . . . . . . . . . . . . . . . . 45

2.1.1 Síntese do complexo dicloro-2,2'-bipiridina-platina(II) . . . . . . 45

2.1.2 Síntese da supermolécula tetracloreto meso-tetra(4-piridil)-porfirinatetrakis- $\left(2,2^{\prime}\right.$-bipiridina-cloro-platina(II) $\ldots \ldots . . \ldots 46$

2.1.3 Síntese da supermolécula tetracloreto meso-tetra(3-piridil)-porfirinatetrakis- $\left(2,2^{\prime}\right.$-bipiridina-cloro-platina(II) . . . . . . . . . . 46

2.2 Métodos . . . . . . . . . . . . . . . . . . . . . . . 49

2.2.1 Titulações espectrofotométricas dos pares iônicos . . . . . . . . 49

2.2.2 Estudos de interação com DNA . . . . . . . . . . . . . . . . . . 49

2.2 .3 Modelagem molecular . . . . . . . . . . . . . . . 50

2.3 Instrumentos . . . . . . . . . . . . . . . . . . . . . 50

2.3.1 Análise térmica . . . . . . . . . . . . . . . . . 50

2.3.2 Espectrometria de massa com ionização por spray de elétrons . 51

2.3.3 Espectroscopia eletrônica . . . . . . . . . . . . . . . . . 51

2.3.4 Espectroscopia vibracional . . . . . . . . . . . . . . . 51

2.3.5 Eletroquímica e espectroeletroquímica . . . . . . . . . . 51

2.3.6 Ressonância magnética nuclear de platina-195 . . . . . . . . . . 52

2.3.7 Microscopia de força atômica . . . . . . . . . . . . . . 52

2.3.8 Ressonância plasmônica de superfície . . . . . . . . . . . . . . 53

3 Resultados e Discussões $\quad 54$

3.1 Análise Térmica . . . . . . . . . . . . . . . . . . . . . 54

3.2 Espectrometria de Massa com Ionização por Spray de Elétrons . . . . . 58

3.3 Ressonância Magnética Nuclear de Platina-195 . . . . . . . . . . . . 65

3.4 Espectroscopia Vibracional . . . . . . . . . . . . . . . . . . . . 67

3.5 Modelagem Molecular . . . . . . . . . . . . . . . . . . . . . . . 69

3.6 Espectroscopia Eletrônica . . . . . . . . . . . . . . . . . . . . . . . 74

3.6.1 Espécies metaladas . . . . . . . . . . . . . . . . . . 78 
3.7 Eletroquímica . . . . . . . . . . . . . . . . . . . . . 81

3.7.1 Ensaio de eletrocatálise . . . . . . . . . . . . . . 85

3.8 Espectroeletroquímica . . . . . . . . . . . . . . . . . . . 88

3.9 Estudos de Interação com DNA . . . . . . . . . . . . . . . . . . . . . . 93

3.9.1 Titulações Espectrofotométricas . . . . . . . . . . . . . . . . 93

3.9.2 Ressonância Plasmônica de Superfície . . . . . . . . . . . . . . . 96

3.10 Complexos Associados por Pareamento Iônico . . . . . . . . . . . . . . 107

3.11 Microscopia de Varredura por Sonda . . . . . . . . . . . . . . . . . . 113

4 Considerações finais $\quad 120$

$\begin{array}{ll}\text { Referências Bibliográficas } & 123\end{array}$

$\begin{array}{ll}\text { A Supermoléculas com } \operatorname{Pt}(\mathrm{tpy})^{2+} \text { e } \mathrm{Pt}(\mathrm{dcbpy}) \mathrm{Cl}^{+} & \mathbf{1 4 0}\end{array}$

A.1 Síntese do complexo $[\mathrm{Pt}(\mathrm{tpy}) \mathrm{Cl}] \mathrm{Cl} \ldots \ldots$. . . . . . . . . . . 140

A.1.1 Primeira etapa . . . . . . . . . . . . . . . . . 140

A.1.2 Segunda etapa. . . . . . . . . . . . . . . . . . 141

A.2 Síntese do complexo $\left[\mathrm{Pt}(\mathrm{dcbpy}) \mathrm{Cl}_{2}\right] \ldots \ldots \ldots$

A.3 Síntese da supermolécula $\left\{4-\mathrm{TPyP}[\mathrm{Pt}(\mathrm{tpy}) \mathrm{Cl}]_{4}\right\}^{8+} \ldots \ldots$. . . . . . . 142

A.4 Síntese da supermolécula $\left\{3-\mathrm{TPyP}\left[\mathrm{Pt}(\mathrm{tpy}) \mathrm{Cl}_{4}\right\}^{8+} \ldots \ldots\right.$. . . . . . . 142

A.5 Síntese da supermolécula $\left\{4-\mathrm{TPyP}[\mathrm{Pt}(\mathrm{dcbpy}) \mathrm{Cl}]_{4}\right\}^{4+} \ldots \ldots \ldots \ldots$

$\begin{array}{ll}\text { B Curriculum Vitae do Autor } & 148\end{array}$ 


\section{Lista de Figuras}

1.1 Uma rota química para a nanotecnologia molecular [1]. . . . . . . . . . 4

1.2 Um esquema ilustrativo das dimensões em nanotecnologia [2]. . . . . . 5

1.3 Copa do mundo molecular: Analogia entre as formas da copa do mundo de futebol (esq.) e o modelo de um fulereno-calix[4]areno otimizado por PM3 (dir.) [3]. . . . . . . . . . . . . . . . . . 6

1.4 A química supramolecular como a ciência da matéria organizada na interface da química com a física e a biologia [4] . . . . . . . . . . . . . 6

1.5 Exemplo de auto-organização hierárquica, onde é formado inicialmente rosetas hexaméricas e num segundo nível de organização formam-se na-

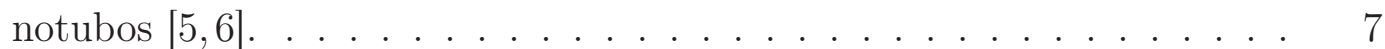

1.6 Exemplos de alguns ligantes comumente utilizados na síntese de complexos supermoleculares. . . . . . . . . . . . . . . . . . .

1.7 Diagrama simplificado dos elementos necessários para um aparato fotossintético artificial. Efeito antena e eventos que ocorrem após absorção de luz, levando a fotodecomposição da água em $\mathrm{H}_{2}$ e $\mathrm{O}_{2}$ [7]. . . . . . . 10

1.8 Arranjo dos cofatores e do par especial no PSII. Os números indicam a distância em $\AA$ [8]. . . . . . . . . . . . . . . . . . . . . . . . . . . . 11

1.9 Esquema da membrana fotossintética artificial onde é ilustrado o mecanismo de transporte foto-induzido de prótons $[9] . \ldots \ldots \ldots . . .$. 
1.10 (a) e (b) Complexos polinclueares de $\mathrm{Ru}(\mathrm{II}), \mathrm{Re}(\mathrm{I})$ e Os(III) coordenados a terpy e bipy e conectados por grupos ponte cianeto e fenileno. c) Complexo decanuclear de $\mathrm{Ru}(\mathrm{II})$ (esferas claras) e Os(III) (esferas escuras) coordenados a dpp e bipy e d) Supermolécula obtida pela coordenação de clusters de $\mathrm{Ru}(\mathrm{II}, \mathrm{III})$ a TPyP. . . . . . . . . . . . . . . .

1.11 Ilustração do critério fotoquímico e eletroquímico para classificar uma espécie química complexa como supramolecular ou molécula grande (o símbolo indica qualquer interação química que mantenha A e B ligados. 15

1.12 Estrutura das supermoléculas de tetrapiridilporfirinas tetracoordenadas a complexos de rutênio e ferro. . . . . . . . . . . . . . . . . . . 18

1.13 (a) Representação estrutural da TRu(bipy)TPyPZn e (b) TRu(phen)TPyPZn. (c) Curva IPCE para os dispositivos $\mathrm{TiO}_{2} / \mathrm{TRu}($ bipy)TPyPZn (-•-); $\mathrm{TiO}_{2} / \mathrm{TRu}\left(\right.$ phen)TPyPZn (-口-); base-livre TRu(bipy)TPyP (-ム-) e $\mathrm{TiO}_{2}$ sem sensibilizador(- $\square$-). A linha sólida corresponde ao espectro de absorção da TRu(bipy)TPyPZn em MeCN [10]. . . . . . . . . . . . . . . . 21

1.14 Formação de filmes de pares iônicos por dip coating onde é demonstrando o padrão de empilhamento adotado e modelo proposto para o processo de transferência de carga . . . . . . . . . . . . . . .

1.15 a) Estrutura da CoTCP e ZnTPPS b) Variação do espectro UV-VIS com o número de camadas e plotagem linear da absorvância a 439 nm em função do número de deposições sucessivas do filme (inserção). . . .

1.16 Estrutura da cis-platina (a) e carboplatina (b) . . . . . . . . . . . . 27

1.17 (a) Estrutura do aduto cis-[Pt( $\left.\left.\mathrm{NH}_{3}\right)_{2}\{\mathrm{~d}(\mathrm{pGpG})\}\right]$. (b) Projeção do aduto ao longo da cadeia. . . . . . . . . . . . . . . . . . . . .

1.18 (a) Modelo da intercalação de PtL ( $\mathrm{L}=$ terpy, bipy ou phen) e (b) efeito da intercalação sobre a distância entre os pares de base na dupla hélice. 
1.19 a) Diagrama ORTEP da estrutura molecular da $\left[\mathrm{Pt}\right.$ (bipy) $\left.\mathrm{Cl}_{2}\right]$ (nível de probabilidade de 50\% para os elipsóides térmicos dos átomos não hidrogenóides) e b) Projeção do conteúdo da cela cristalina a 294 K [11,12].

1.20 Diagrama ORTEP de a) $\left[\mathrm{Pt}(\right.$ terpy $) \mathrm{Cl} \mathrm{ClO}_{4}$ e os dois modos de interação cátion-cátion ao longo da cadeia (nível de probabilidade de 50\% para os elipsóides térmicos dos átomos não hidrogenóides). b) Pt. . Pt a 4,20 ^ (cristais laranja) e c) Pt...Pt a 3,27 ̊ (cristais vermelhos) [12] . . . .

1.21 Exemplos de quadrados moleculares obtidos por auto-montagem de complexos diimínicos de $\mathrm{Pt}(\mathrm{II})$ e $\mathrm{Pd}(\mathrm{II})$.

1.22 Complexos supermoleculares de platina(II)-polipiridinas. a) As setas e os números indicam as distâncias em A. b) Projeção do arranjo molecular na cela unitária. . . . . . . . . . . . . . . . .

1.23 Estruturas supermoleculares contendo até 12 centros de platina . . . . 34

1.24 Dímeros e tetrâmeros de Pt(II) e Pd(II) coordenados a 10,15,20-trifenil5-piridil-porfirinato de zinco(II) e 15,20-difenil-5,10-dipiridil-porfirinato de zinco(II) [13].

1.25 Nonâmero de multiporfirinas coordenadas a Pd(II). (1) Modelo teórico para $\mathrm{R}=\mathrm{CH}_{3}$, (2) Representação estrutural e (3) imagens AFM obtidas sobre vidro $(3 \mathrm{a})$, mica $(3 \mathrm{~b})$ e ouro $(3 \mathrm{~b}) \ldots \ldots . \ldots 37$

1.26 Fios moleculares de porfirinas coordenadas a cis- $\left[\mathrm{PtCl}_{2}\right]^{2+}$ e trans- $\left[\mathrm{PdCl}_{2}\right]^{2+} .38$

1.27 Quadrados moleculares de piridilporfirinas coordenadas a complexos bifosfínicos de $\mathrm{Pt}(\mathrm{II})$ e $\mathrm{Pd}(\mathrm{II})$.

1.28 Representação estrutural dos complexos (a) cis- $\left\{\mathrm{Pt}\left[(\mathrm{pyPP}) \mathrm{H}_{2}\right]_{2} \mathrm{Cl}_{2}\right\}$ e (b) $\left\{\mathrm{M}\left[(\mathrm{pyP}) \mathrm{H}_{2}\right]_{4} X_{2}\right\}\left(\mathrm{M}=\mathrm{Pt}^{2+}\right.$ e $\mathrm{Pd}^{2+} ; \mathrm{X}=\mathrm{BF}_{4}^{-}$e OTf- $) \ldots . .$.

1.29 Estrutura cristalina/molecular para $\left.\left\{[\mathrm{Pd}(\mathrm{DPPP})]\left[(\text { pyTP }) \mathrm{H}_{2}\right)_{2}(\mathrm{OTf})_{2}\right]\right\}$ (nível de probabilidade de 50\% para os elipsóides térmicos dos átomos não hidrogenóides). . . . . . . . . . . . . . . . . . . . . . . 40

1.30 Complexos de platina(II)-porfirina com potencial atividade biológica. 41 
1.31 Fragmentos precursores para a síntese de novas supermoléculas de platina(II)tetrapiridilporfirinas. . . . . . . . . . . . . . . . 43

2.1 Estrutura do complexo $\left[\mathrm{Pt}(\right.$ bipy $\left.) \mathrm{Cl}_{2}\right]$ com indicação das atribuições para ${ }^{1} \mathrm{H}$ RMN . . . . . . . . . . . . . . . . . . . . 46

2.2 Estrutura da nova supermolécula 4-TPtTPyP. . . . . . . . . . . . . . 47

2.3 Estrutura da nova supermolécula 3 -TPtTPyP . . . . . . . . . . . . . . 48

3.1 Curva termogravimétrica e dTG para $\left[\mathrm{Pt}(\right.$ bipy $\left.) \mathrm{Cl}_{2}\right] \ldots \ldots$. . . . . . 55

3.2 Curva termogravimétrica e dTG para 3-TPyP. . . . . . . . . . . . 55

3.3 Curvas termogravimétricas e dTG para a) 3-TPtTPyP e b) 4-TPtTPyP. 57

3.4 Padrão de fragmentação esperado para 4-TPtTPyP. . . . . . . . . . . 59

3.5 Padrão de fragmentação esperado para 3-TPtTPyP . . . . . . . . . . . 60

3.6 Espectros ESI-MS no modo íon positivo para 4-TPtTPyP (4) e 3-TPtTPyP

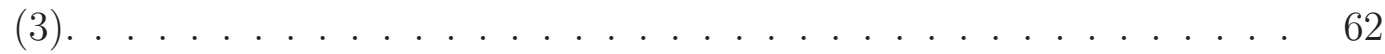

3.7 a) e b): ESI-MS/MS do íon de m/z $541(\mathrm{CE}=12)$. c) ESI-MS/MS do íon de $\mathrm{m} / \mathrm{z} 592(\mathrm{CE}=20) \ldots \ldots \ldots \ldots 63$

3.8 a) e b): ESI-MS/MS do íon de m/z $541(\mathrm{CE}=12)$. c) ESI-MS/MS do íon de $\mathrm{m} / \mathrm{z} 592(\mathrm{CE}=12) \ldots \ldots \ldots$. . . . . . . . . . 64

3.9 Espectros de ${ }^{195} \mathrm{Pt} \mathrm{RMN} 500 \mathrm{MHz}$ das espécies (a) [Pt(bipy) $\left.\mathrm{Cl}_{2}\right] \quad 0,4$ $\mathrm{mol} \cdot \mathrm{dm}^{-3}$ em DMF (b) 4-TPtTPyP $2 \times 10^{-2} \mathrm{~mol} \cdot \mathrm{dm}^{-3}$ em TFE e (c) 3TPtTPyP $2 \times 10^{-2} \mathrm{~mol} \cdot \mathrm{dm}^{-3}$ em TFE contendo $\left[\mathrm{Pt}(\right.$ bipy $\left.) \mathrm{Cl}_{2}\right]$ em excesso. 66

3.10 Espectros no infravermelho para os compostos [Pt(bipy) $\left.\mathrm{Cl}_{2}\right]$, 4-TPtTPyP, 3-TPtTPyP e 4-TPyP. . . . . . . . . . . . . . . 68

3.11 Otimização de geometria para a supermolécula 4-TPtTPyP. Projeção frontal (sup.) e lateral (inf.). Legenda dos átomos: amarelo - Pt, verde - Cl, azul - C, branco - H e laranja - N . . . . . . . . . . . . 
3.12 Otimização de geometria para a supermolécula 3-TPtTPyP. Projeção frontal (sup.) e lateral (inf.). Legenda dos átomos: amarelo - Pt, verde - Cl, azul - C, branco - H e laranja - N . . . . . . . . . . .

3.13 Representação dos orbitais moleculares HOMO (a) e LUMO (b) da 4TPtTPyP e HOMO (c) e LUMO (d) da 3-TPtTPyP.

3.14 Espectro UV/VIS do complexo $\left[\mathrm{Pt}(\right.$ bipy $\left.) \mathrm{Cl}_{2}\right] 3,8 \times 10^{-6} \mathrm{~mol} \cdot \mathrm{dm}^{-3} \mathrm{em}$

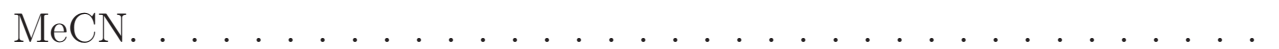

3.15 Espectro eletrônico da 4-TPtTPyP $4 \times 10^{-6} \mathrm{~mol} \cdot \mathrm{dm}^{-3}$ em TFE. Inserção: bandas Q, solução $6 \times 10^{-6} \mathrm{~mol} \cdot \mathrm{dm}^{-3} \ldots$. . . . . . . . . . . . 76

3.16 Espectro eletrônico da 3-TPtTPyP 4,5 x $10^{-6} \mathrm{~mol} \cdot \mathrm{dm}^{-3}$ em TFE. Inserção: bandas Q, solução 6 × $10^{-6} \mathrm{~mol} \cdot \mathrm{dm}^{-3}$

3.17 Espectro eletrônico da espécie 4-TPtTPyPZn (-) obtido da titulação de 4-TPtTPyP (- - ) com $\mathrm{Zn}\left(\mathrm{CH}_{3} \mathrm{COO}\right)_{2} 1 \times 10^{-3} \mathrm{~mol} \cdot \mathrm{dm}^{-3} \mathrm{em} \mathrm{MeOH}$.

3.18 Espectro eletrônico da espécie 3-TPtTPyPZn (-) obtido da titulação de 3-TPtTPyP (- - ) com $\mathrm{Zn}\left(\mathrm{CH}_{3} \mathrm{COO}\right)_{2} 1 \times 10^{-3} \mathrm{~mol} \cdot \mathrm{dm}^{-3} \mathrm{em} \mathrm{MeOH}$.

3.19 Voltamogramas cíclicos da 4-TPtTPyP medidos a 20, 50, 100 e 200 $\mathrm{mV} / \mathrm{s}$. (a) Varredura no sentido catódico e (b) Varredura no sentido anódico. Solução 0,5mM em DMF-TEAClO 4 0,1M. Eletrodo de platina

3.20 Voltamogramas cíclicos da 3-TPtTPyP medidos a 20, 50, 100 e 200 $\mathrm{mV} / \mathrm{s}$. (a) Varredura no sentido catódico e (b) Varredura no sentido anódico. Solução 0,5mM em DMF-TEAClO 4 0,1M. Eletrodo de platina.

3.21 Voltamogramas cíclicos a $50 \mathrm{mV} / \mathrm{s}$ com diferentes janelas de potencial de uma solução 0,5 mM de 4-TPtTPyP em DMF-TEAClO 4 0,1M, eletrodo de platina. Varredura no sentido catódico. . . . . . . . . . . .

3.22 Voltamogramas cíclicos de uma solução tampão acetato contendo 5,2×10 $10^{-3}$ $\mathrm{mmol} \cdot \mathrm{dm}^{-3}$ de $\mathrm{NO}_{2}^{-}$. Eletrodo de carbono vítreo modificado com filme de 4 -TPtTPyP $(-)$ e não modificado $(-\cdot--)$. . . . . . . . . . . . 
3.23 Eletrodo de carbono vítreo modificado com filme de 4-TPtTPyP. a) Voltamogramas cíclicos em solução tampão acetato, $\mathrm{pH}=4,7$, contendo 0 a $5,2 \times 10^{-3} \mathrm{mmol} \cdot \mathrm{dm}^{-3}$ de $\mathrm{NO}_{2}^{-}$. (b) Relação i x $\left[\mathrm{NO}_{2}^{-}\right]$para a região de redução e (c) Relação i x $\left[\mathrm{NO}_{2}^{-}\right]$para a região de oxidação. . . . . . 87

3.24 Espectroeletroquímica na região de oxidação das supermoléculas 4-TPtTPyP e 3-TPtTPyP. Soluções $1 \times 10^{-4} \mathrm{~mol} \cdot \mathrm{dm}^{-3}$ em DMF, TEAClO 4 . Potencial aplicado $=1$ V. . . . . . . . . . . . . . . . . . . . . 89

3.25 Espectroeletroquímica na região de redução da 4-TPtTPyP. Solução $1 \mathrm{x} 10^{-4} \mathrm{~mol} \cdot \mathrm{dm}^{-3} \mathrm{em} \mathrm{DMF}, \mathrm{TEAClO}_{4}$. Espectros sucessivos obtidos com potenciais de $-1,35,-1,45 \mathrm{~V},-1,75 \mathrm{~V} \ldots \ldots \ldots$

3.26 Espectroeletroquímica na região de redução da 3-TPtTPyP. Solução $1 \times 10^{-4} \mathrm{~mol} \cdot \mathrm{dm}^{-3}$ em DMF, TEAClO ${ }_{4}$. Espectros sucessivos obtidos com potenciais de $-1,30$ e $-1,70 \mathrm{~V} \ldots \ldots \ldots$

3.27 Titulação espectrofotométrica da 4-TPtTPyP $1,6 \times 10^{-5} \mathrm{~mol} \cdot \mathrm{dm}^{-3} \mathrm{em}$ tampão Tris-HCl com 10\% TFE. Adição de alíquotas de 10, 20, 30, 40, 60,120 e $200 \mu \mathrm{L}$ de DNA $2,2 \times 10^{-4} \mathrm{~mol} \cdot \mathrm{dm}^{-3} \ldots \ldots \ldots$. . . . . .

3.28 Solução de 4-TPtTPyP 8,2x10-6 $\mathrm{mol} \cdot \mathrm{dm}^{-3}$ preparada em: TFE, água, tampão tris- $\mathrm{HCl}(\mathrm{pH} 7,4)$ e tampão fosfato $(\mathrm{pH} 6,9)$. . . . . . . . . .

3.29 Titulação espectrofotométrica da 3 -TPtTPyP $1,6 \times 10^{-5} \mathrm{~mol} \cdot \mathrm{dm}^{-3} \mathrm{em}$ tampão Tris-HCl com 10\% TFE. Adição de alíquotas de 20, 40, 80, 120 e $280 \mu \mathrm{L}$ de DNA $8,7 \times 10^{-5} \mathrm{~mol} \cdot \mathrm{dm}^{-3} \ldots \ldots \ldots$. . . . . . . .

3.30 (a) Representação esquemática da configuração de Kretchmann para SPR. O dielétrico em contato com o metal possibilita a transferência ressonante de energia da onda incidente para a OPS; (b) Curvas de refletância na ausência $\left(\Theta_{S P R 1}\right)$ e presença $\left(\Theta_{S P R 2}\right)$ de espécies na superfície do filme metálico; (c) Sensorgrama esquemático representativo da relação entre o angulo SPR $\left(\Theta_{S P R}\right)$ e tempo durante a interação de espécies com a superfície do filme metálico [14]. 
3.31 Exemplo de um gráfico de interação SPR. . . . . . . . . . . . . . . . 97

3.32 Determinação dos valores de $\mathrm{k}_{s}$ pelo método de linearização. Curvas simuladas da fase de associação de uma interação bimolecular em cinco concentrações diferentes do analito. . . . . . . . . . . . . . . 100

3.33 Gráfico da interação SPR de a) Cisteamina-DNA-4-TPtTPyP. b) CisteaminaDNA-3-TPtTPyP. . . . . . . . . . . . . . . . 101

3.34 Variação do ângulo contra o tempo na interação de DNA com cisteamina, obtido a partir da figura $3.33($ a) . . . . . . . . . . . . . . . . . 102

3.35 Variação do ângulo contra o tempo na interação de DNA com cisteamina,

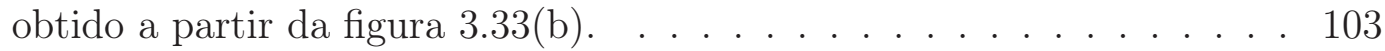

3.36 Variação do ângulo contra o tempo na interação de 3-TPtTPyP com DNA, obtido a partir da figura 3.33(b) . . . . . . . . . . . . . . . 104

3.37 Modelo proposto para o arranjo supramolecular hierárquico do sistema Au-cisteamina-DNA-3TPtTPyP . . . . . . . . . . . . . . 105

3.38 Modelo proposto para o arranjo supramolecular hierárquico do sistema Au-cisteamina-DNA-4TPtTPyP . . . . . . . . . . . . . . 106

3.39 Representação estrutural da CuPcTS. . . . . . . . . . . . . . . . . 107

3.40 Gráfico das titulações envolvendo as espécies 4-TPtTPyP e CuPcTS: a) Titulação da CuPcTS com 4-TPtTPyP. b) Titulação inversa. . . . . . . 109

3.41 Gráfico das titulações envolvendo as espécies 3-TPtTPyP e CuPcTS: a) Titulação da CuPcTS com 3-TPtTPyP. b) Titulação inversa. . . . . . . . 110

3.42 Diagrama de Job para o sistema a) 4-TPtTPyP ${ }^{4+} / \mathrm{CuPcTS}^{4-}, \lambda=420$

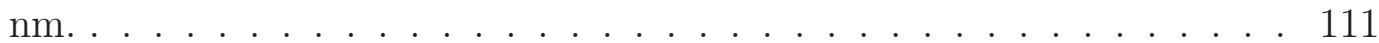

3.43 Diagrama de Job para o sistema 3-TPtTPyP ${ }^{4+} / \mathrm{CuPcTS}^{4-}, \lambda=672$ nm. 111

3.44 Modelo dos heterotrímeros formado pelas espécies 4-TPtTPyP ${ }^{4+} / \mathrm{CuPcTS}^{4-}$ e 3-TPtTPyP ${ }^{4+} / \mathrm{CuPcTS}^{4-} \ldots \ldots \ldots \ldots \ldots . \ldots \ldots 112$

3.45 Esquema geral dos componentes e de suas funções num microscópio de força atômica. . . . . . . . . . . . . . . . . . 113 
3.46 Curva de potencial das forças de van der Waals e os modos de operação na microscopia de varredura por sonda. . . . . . . . . . . . . . . . 114

3.47 Imagem SPM ( $5 \times 5 \mu \mathrm{m})$ no modo contato intermitente (MAC Mode) do filme de 4-TPtTPyP depositado sobre mica. . . . . . . . . . . . . . . 115

3.48 Imagem SPM $(5 \times 5 \mu \mathrm{m})$ no modo contato intermitente do filme de 3TPtTPyP depositado sobre mica. . . . . . . . . . . . . . 116

3.49 Modelo de organização proposta para a origem das estruturas colunares observadas nas imagens SPM da 4-TPtTPyP e 3-TPtTPyP. . . . . . . 117

3.50 Modelo de organização proposta para a origem das estruturas colunares tipo tubo observado nas imagens SPM da 4-TPtTPyP. . . . . . . . . 117

3.51 Imagem SPM $(5 \times 5 \mu \mathrm{m})$ no modo contato intermitente do filme de 4TPtTPyP/CuPcTS depositado sobre mica. . . . . . . . . . . . . . 118

3.52 Imagem SPM $(5 \times 5 \mu \mathrm{m})$ no modo contato intermitente do filme de 3TPtTPyP $/$ CuPcTS depositado sobre mica. . . . . . . . . . . . . . . 119

A.1 Estrutura do complexo $[\mathrm{Pt}(\mathrm{tpy}) \mathrm{Cl}] \mathrm{Cl}$ com indicação das atribuições de ${ }^{1} \mathrm{H}$ RMN . . . . . . . . . . . . . . . . . . . . 141

A.2 Representação estrutural da supermolécula 4-TPt(terpy)TPyP. . . . . . 143

A.3 Representação estrutural da supermolécula 3-TPt(terpy)TPyP. . . . . . 144

A.4 Espectro eletrônico da 4-TPt(terpy)TPyP 4x10 ${ }^{-6} \mathrm{~mol} \cdot \mathrm{dm}^{-3}$ em TFE. . 145

A.5 Espectro eletrônico da 3-TPt(terpy)TPyP 4x10 ${ }^{-6} \mathrm{~mol} \cdot \mathrm{dm}^{-3} \mathrm{em} \mathrm{MeOH.} 146$

A.6 Representação estrutural da supermolécula 4-TPt(dcbipy)TPyP . . . . 147

A.7 Espectro eletrônico da 3-TPt(dcbpy)TPyP $6 \times 10^{-6} \mathrm{~mol} \cdot \mathrm{dm}^{-3}$ em solução aquosa de $\mathrm{NaOH} 5 \mathrm{mM}$. 


\section{Lista de Tabelas}

3.1 Valores de $\mathrm{m} / \mathrm{z}$ e $\Delta(\mathrm{m} / \mathrm{z})$ obtido nos espectros ESI-MS das supermoléculas 4 -TPtTPyP (4) e 3 -TPtTPyP (3) . . . . . . . . . . . . . . 61

3.2 Dados de espectroscopia eletrônica para os compostos 4-TPyP, [Pt(bipy) $\left.\mathrm{Cl}_{2}\right]$, 4 -TPtTPyP e 3-TPtTPyP. . . . . . . . . . . . . . . . 80

3.3 Constantes de velocidade de associação e de equilíbrio na interação SPR de cisteamina-DNA-3TPtTPyP. . . . . . . . . . . . . . . . . . 104 


\section{Capítulo 1}

\section{Introdução}

\subsection{Química Supramolecular e Nanotecnologia}

Enquanto que o ano de 1892 representa o nascimento da Química de Coordenação, quando Alfred Werner concebeu sua teoria dos complexos metálicos [15], o ano de 1987, quando J.-M. Lehn, D.J. Cram e C.J. Pedersen foram laureados com o Prêmio Nobel em Química [16], serve como um marco para o surgimento e a consolidação da Química Supramolecular como uma nova área de pesquisa dentro da química e ciências afins. O termo supramolecular data de 1978 e alguns autores tomam como referência o ano de 1967 para o nascimento da área, quando C.J. Pedersen descobriu os éteres de coroa. Mas é somente após 1987 que o número de grupos envolvidos, o número de artigos, livros e conferências sobre o tema cresce enormemente [17-20].

Sendo por excelência uma área multidisciplinar, a Química Supramolecular representa um dos aspectos mais inovadores e revolucionários da química nas últimas décadas. Com o impacto destas idéias, abriu-se um amplo horizonte para esse novo campo, cuja evolução natural das pesquisas levou a um contínuo crescimento da área, que ainda é observado nos dias atuais. Inicialmente a química supramolecular foi conceituada como a química dos sistemas obtidos pela auto-montagem (self assembly) de várias espécies moleculares através de interações intermoleculares não-covalentes, levando a 
estruturas complexas altamente organizadas.

Entretanto, um conceito restrito à natureza das ligações formadas entre as espécies logo mostrou-se limitado para se definir inequivocamente um sistema supramolecular. Em um nível mais abrangente, pode-se definir como supramolecular todo sistema inspirado em auto-montagem e que preserve a identidade das unidades precursoras (building blocks), atribuindo propriedades novas, inerentes ao conjunto. Ou seja, os sistemas supramoleculares não representam necessariamente a soma direta das propriedades das moléculas integrantes, mas tendem a adquirir propriedades sinérgicas, típicas do sistema como um todo. Daí a origem do termo supramolecular e a definição universal adotada por Lehn de que "a química supramolecular é a química além da molécula".

Nesse âmbito, entram em jogo processos de associação molecular através de ligações de hidrogênio, ligações coordenativas metal-ligante, interações eletrostáticas entre espécies de cargas opostas, interações eletrônicas $\pi$ - $\pi$, ligações covalentes em dendrímeros, etc. Essa organização molecular associada à formação de unidades mais complexas pode levar a sistemas químicos inteligentes, dotados de capacidade de comunicação, reconhecimento molecular, transporte de energia e de elétrons $[1,4,20-22]$. Ou seja, ao invés do enfoque estar centrado nas propriedades e ações isoladas das moléculas individuais, como ocorre na química tradicional, os sistemas supramoleculares podem desenvolver funções específicas, executando tarefas de forma análoga à máquinas macroscópicas [4,22-24].

Exemplos característicos de estruturas supramoleculares são encontrados em abundância nos sistemas biológicos. Neles as transformações ocorrem de forma seqüencial, através do encadeamento das biomoléculas, geralmente dispostas em membranas ou grandes estruturas protéicas, as quais proporcionam o arranjo supramolecular necessário para a ocorrência das transformações com alta especificidade e eficiência. Um exemplo típico é o mecanismo da fotossíntese, onde a energia solar é transformada em energia química através de uma seqüência complexa de transformações nos centros reacionais. 
A referência feita a Werner em paralelo com o surgimento da química supramolecular no início deste capítulo, está baseada no fato que, inserida no contexto da química de coordenação, a química supramolecular representa um passo a frente e um grande desafio para a química inorgânica moderna [1]. Em vista de sua ampla versatilidade ela abre a possibilidade de se planejar as supermoléculas a partir de princípios básicos de química de coordenação, aproveitando as características eletrônicas, estruturais e redox associadas aos íons metálicos e aos ligantes.

O processo de auto-montagem geralmente se dá através de níveis de organização pré-programados. Nesse caso, a formação de espécies supramoleculares por interação direta via metal-ligante funciona como um meio de se direcionar essa pré-organização. Emprega-se para isso os processos seletivos de coordenação, com os complexos metálicos atuando como building blocks. De uma forma geral, pode-se dizer que a química supramolecular ampliou o escopo da química de coordenação para a ligação de qualquer tipo de substrato [25].

Em termos de aplicações, os sistemas supramoleculares vêm sendo concebidos como potenciais substitutos, em escala nanométrica, dos dispositivos eletrônicos e como elementos precursores de novos dispositivos fotônicos, eletrônicos e opto-eletrônicos. Espera-se assim que eles sejam capazes de armazenar e processar informações e de efetuar a foto-conversão de energia, realizando a fotossíntese artificial. Isso sem mencionar potenciais aplicações na medicina como fármacos de ação específica e seletiva $[4,21,22,26,27]$. Nessa abordagem é estabelecida uma aproximação entre a química supramolecular e a nanotecnologia. A figura 1.1, adaptada da referência [1], apresenta uma estratégia possível para se chegar à dispositivos nanotecnológicos a partir da química.

Em Nanociência, ou Nanotecnologia, as estruturas possuem dimensões usualmente na faixa de 1 a 100 nm (veja ilustração na figura 1.2 [2]) e suas propriedades são de grande relevância não só pelo tamanho, mas também porque tendem a exibir características únicas, diferentes daquelas observadas para moléculas ou para compostos 


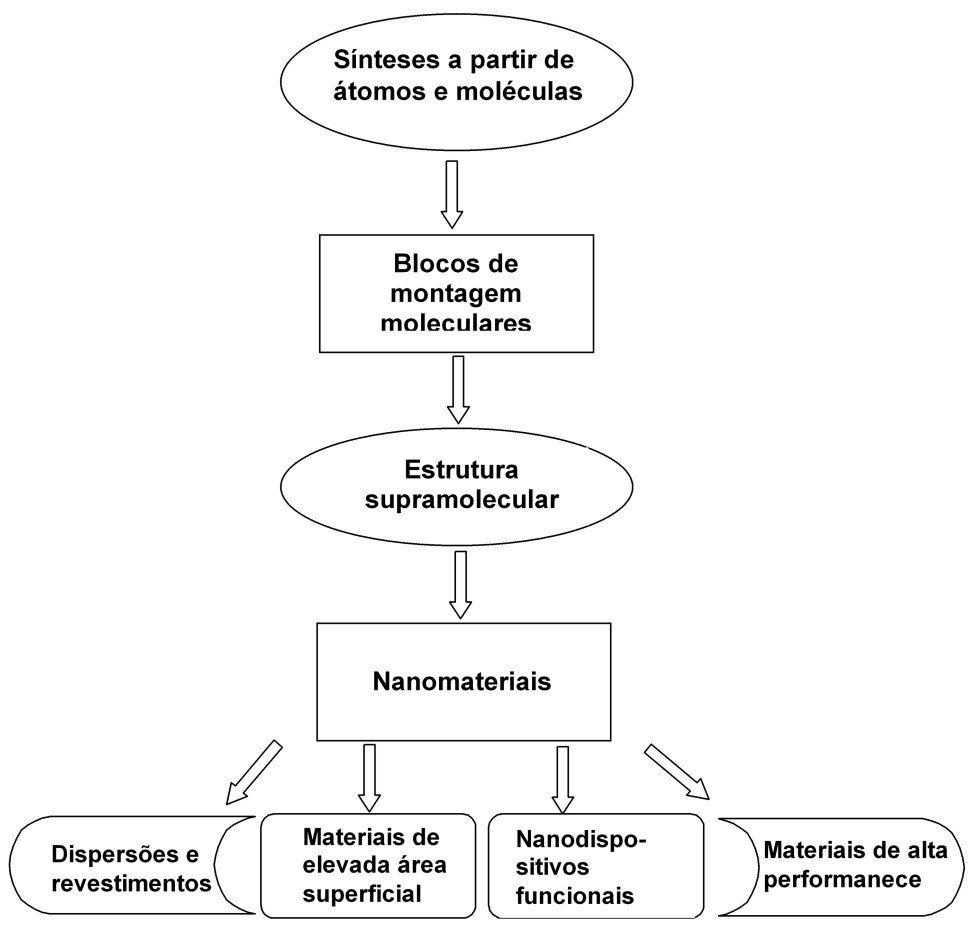

Figura 1.1: Uma rota química para a nanotecnologia molecular [1].

macroscópicos. Uma ilustração interessante desse caráter é o comportamento espectroscópico das nanopartículas de ouro, as quais apresentam cor vermelha em solução, enquanto que o metal e a solução do sal com cianeto são amarelos [28].

Tendo em vista as dimensões almejadas pela nanotecnologia, o problema crucial consiste em como alcançá-las. Neste sentido, a tecnologia dominante e aplicada com grande êxito nas últimas décadas foi o uso da miniaturização, especialmente a litografia. Esta abordagem, conhecida como top down foi amplamente empregada na fabricação de microprocessadores para a microeletrônica e permitiu que até recentemente a Lei de Moore $^{1}$ fosse seguida. No entanto, seus limites físicos de aplicação vêm sendo alcançados.

Uma nova abordagem que vem sendo desenvolvida para substituir e superar a miniaturização, é a nanofabricação, conhecida pelo termo bottom up. É nesse conceito que se encaixa a química supramolecular, uma vez que esta é uma das estratégias mais

\footnotetext{
${ }^{1}$ Relação empírica baseada na afirmação de Gordon Moore que em 1965 previu que o número de transistores num chip dobraria a cada 18 meses [29].
} 

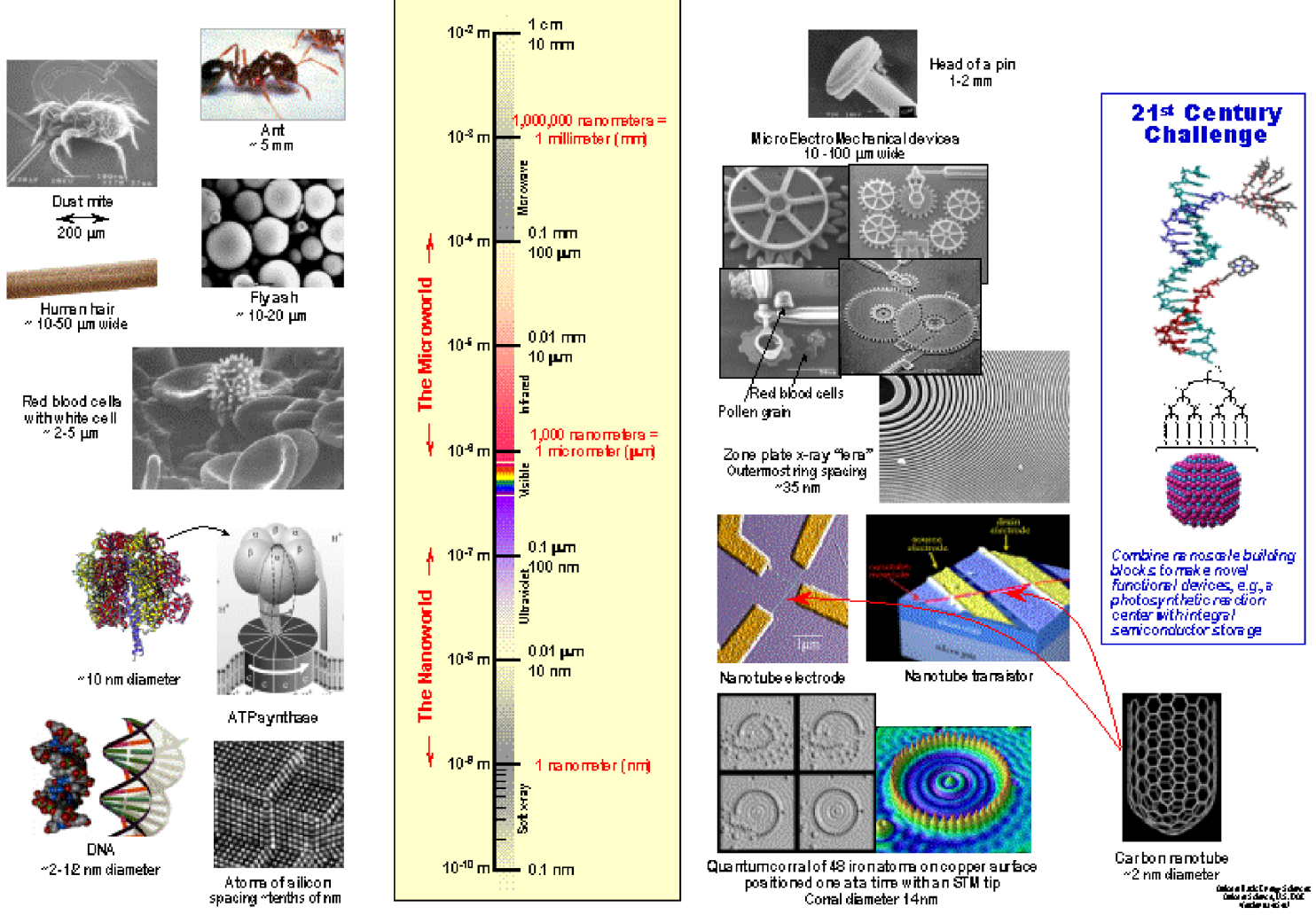

Figura 1.2: Um esquema ilustrativo das dimensões em nanotecnologia [2].

promissoras para a construção de arquiteturas moleculares em escala nanométrica que venham a atuar como nanomáquinas [23,24,30-38]. A figura 1.3 apresenta um exemplo curioso que ilustra a idéia de se transportar propriedades e funções análogas de máquinas ou dispositivos macroscópicos para estruturas nanoscópicas [3].

Claro que esses objetivos, em sua maior parte, permanecem ainda como um grande desafio para a ciência atual ${ }^{2}$ e sua visão está bem retratada nos comentários de J.M.Lehn [4] e de R.J.M. Nolte, um dos idealizadores da química supramolecular hierárquica (figura 1.5) [6]:

"Inspirados pela complexidade e beleza das arquiteturas moleculares encontradas na natureza, encaramos o problema de como manipular moléculas para desenvolver estruturas de similar perfeição e magnificência."

Roeland J. M. Nolte, J. Mater. Chem., 2003

\footnotetext{
${ }^{2} \mathrm{Na}$ edição comemorativa ao $125^{\circ}$ aniversário, "O que nós não sabemos - 125 questões não respondidas pela ciência", a revista Science levanta a questão: Quão longe poderemos levar a automontagem? [39].
} 

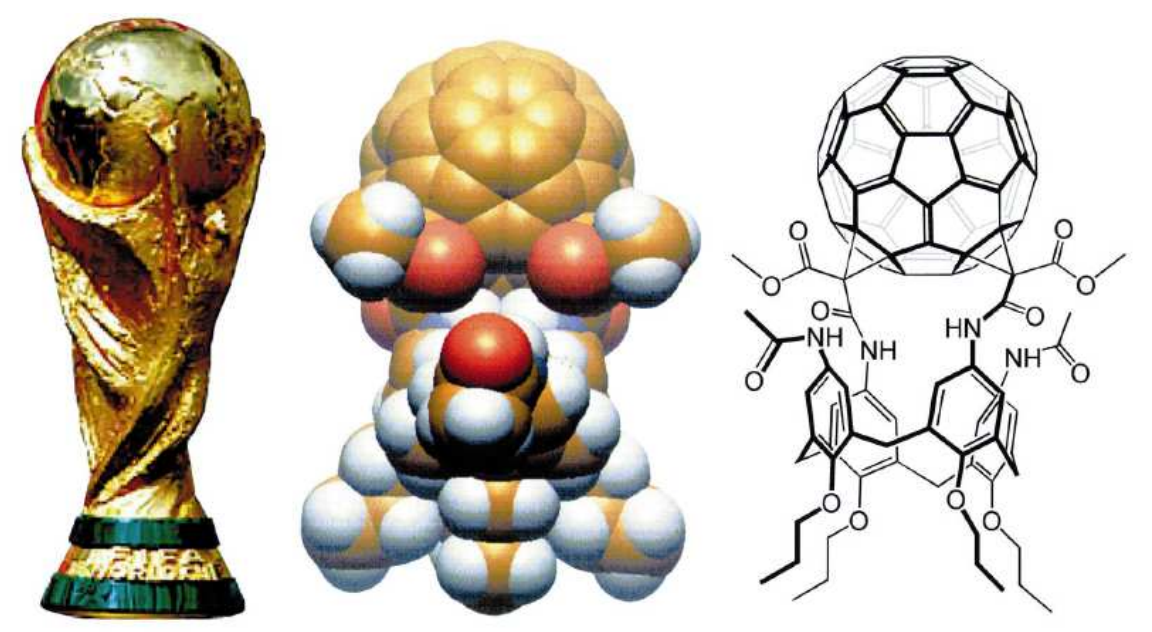

Figura 1.3: Copa do mundo molecular: Analogia entre as formas da copa do mundo de futebol (esq.) e o modelo de um fulereno-calix[4]areno otimizado por PM3 (dir.) [3].

"Através do descobrimento progressivo, da compreensão e implementação das regras que governam a evolução da matéria inanimada até a matéria animada (organismos vivos), atingiremos a capacidade de criar novas formas complexas de matéria (figura 1.4)."

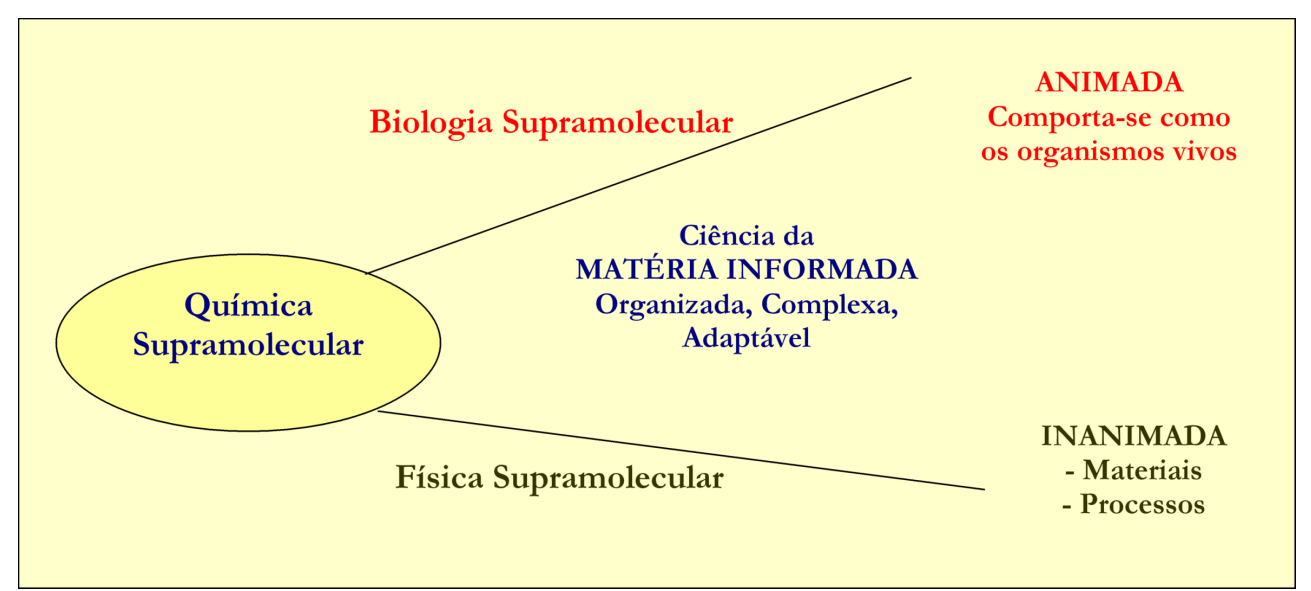

Figura 1.4: A química supramolecular como a ciência da matéria organizada na interface da química com a física e a biologia [4]. 

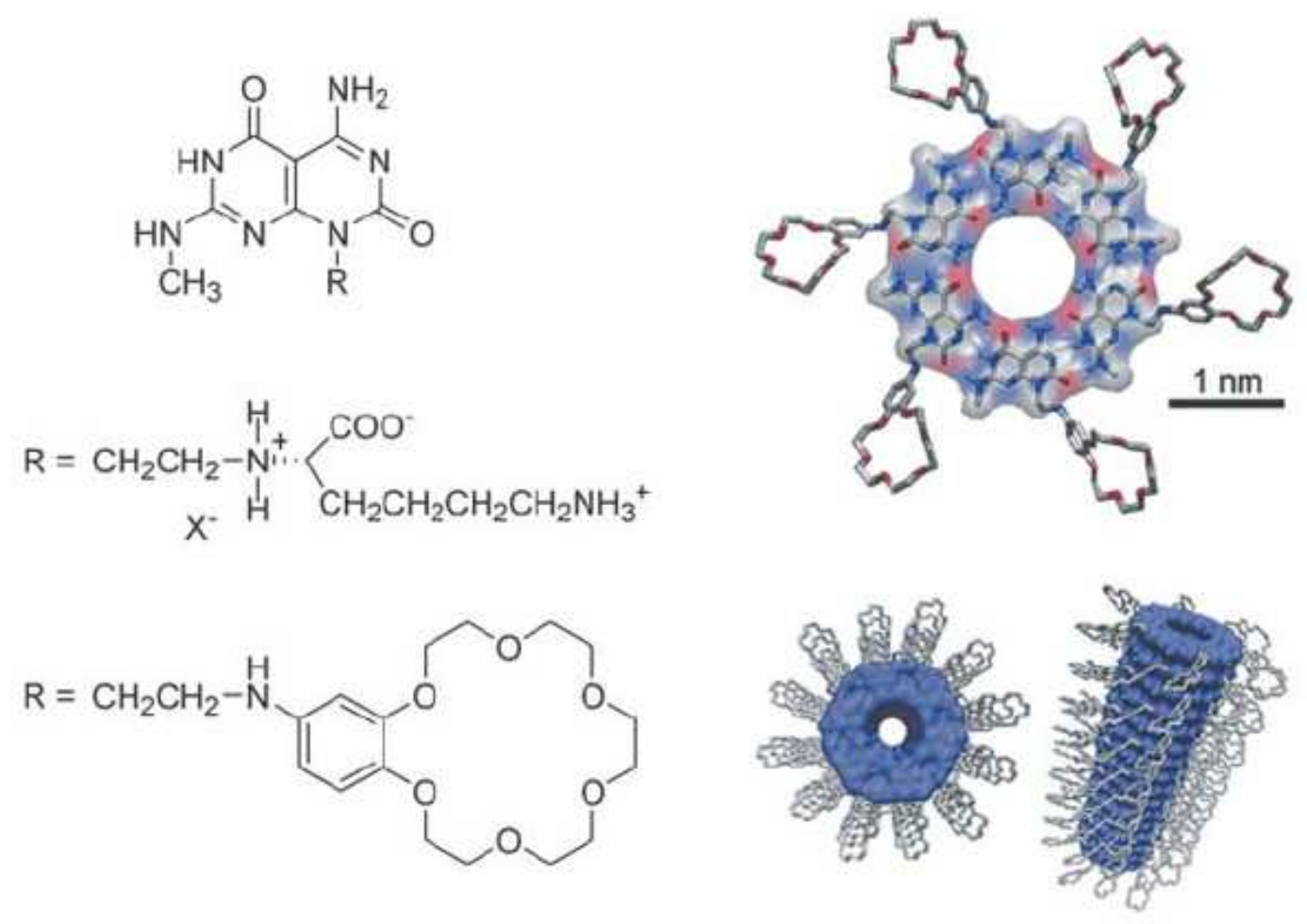

Figura 1.5: Exemplo de auto-organização hierárquica, onde é formado inicialmente rosetas hexaméricas e num segundo nível de organização formam-se nanotubos $[5,6]$. 


\subsection{Compostos de Coordenação Supramoleculares}

Conforme exposto na seção anterior, uma das principais vertentes da química supramolecular está voltada à síntese de complexos de metais de transição polinucleares contendo múltiplas unidades cromóforas e ao estudo de suas propriedades fotoquímicas, fotofísicas e eletroquímicas. Esses sistemas multicomponentes, os quais denominamos aqui Complexos Supermoleculares, são muito interessantes do ponto de vista químico, uma vez que tendem a exibir propriedades centradas nas unidades cromóforas e na estrutura global, tal como se espera de uma entidade supramolecular. Os principais objetivos vinculados ao estudo destes complexos estão focados na obtenção de sistemas que exibam, entre outras propriedades, transferência de energia ou de elétrons fotoinduzidas e/ou redox-induzidas, por sua potencial aplicação como dispositivos fotônicos ou eletrônicos [40,41].

A figura 1.6 apresenta alguns exemplos de ligantes comumente empregados na preparação de complexos supermoleculares. Veja que a predominância é de ligantes quelatos e macrocíclicos, os quais promovem maior estabilidade e rigidez aos sistemas, facilitando assim o controle da geometria e o tamanho da estrutura final obtida. A escolha apropriada dos ligantes e dos íons metálicos permite acessar e pré-programar os diferentes níveis organizacionais. Desse modo, na preparação de espécies supramoleculares, esses ligantes atuam como ligantes do tipo ponte, como no caso da 4,4-bipy, terminais, como 2,2-bipy e centrais, como a 4-TPyP.

Em termos das potenciais aplicações destas supermoléculas na preparação de dispositivos moleculares, um caso de estudo muito ilustrativo que pode-se tomar como modelo é a fotossíntese artificial.

\subsubsection{Fotossíntese Artificial}

Atualmente é indiscutível o valor de sistemas biomiméticos capazes de realizar a fotossíntese artificial para a conversão e armazenagem da energia solar. Em sistemas 


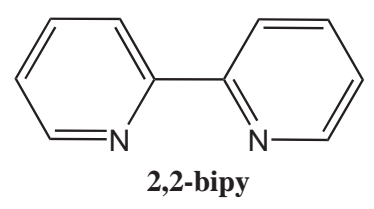<smiles>Oc1cccc(-c2cccc(-c3ccccn3)n2)n1</smiles>

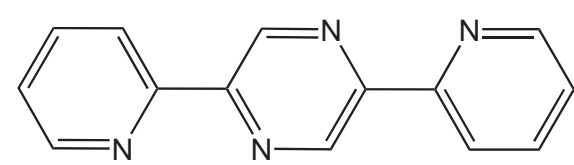

2,5-dpp

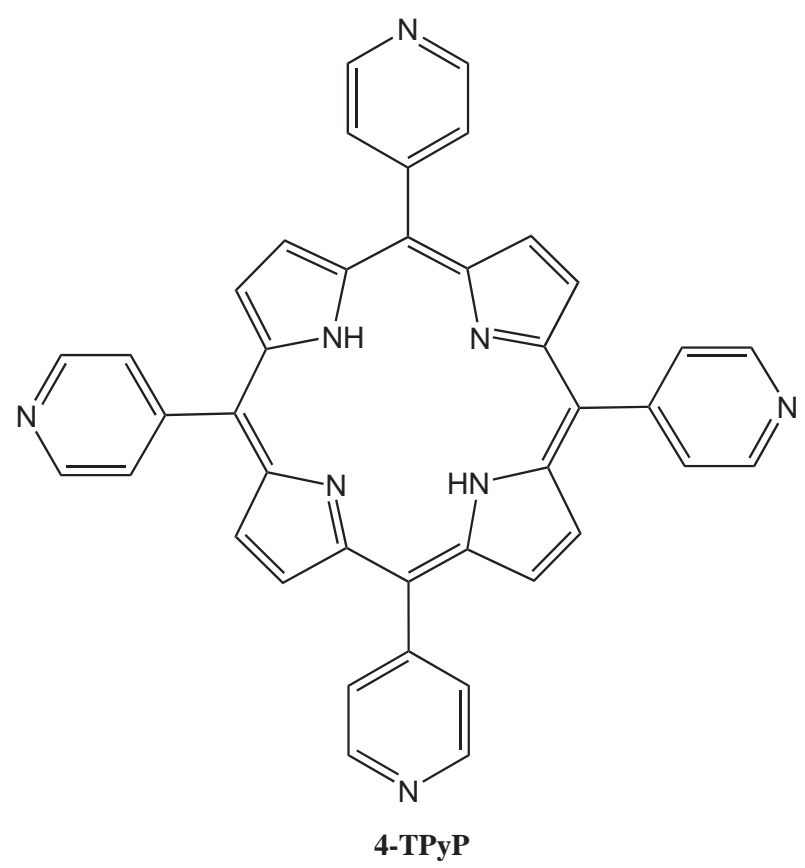

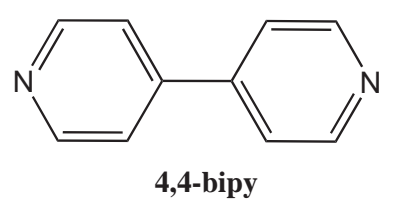
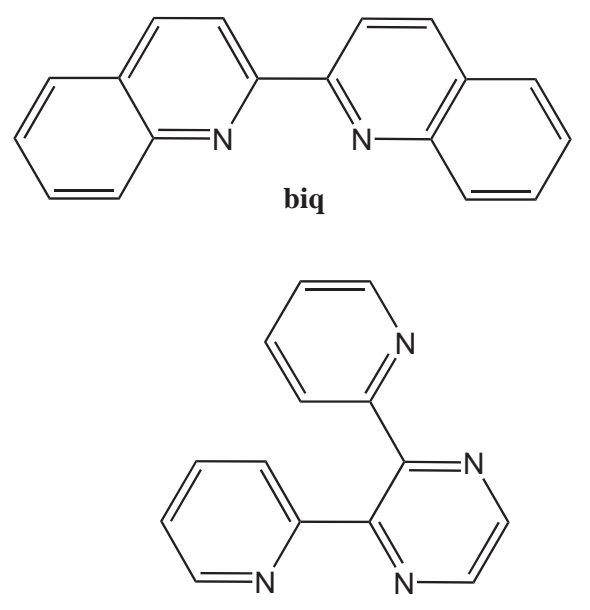

2,3-dpp

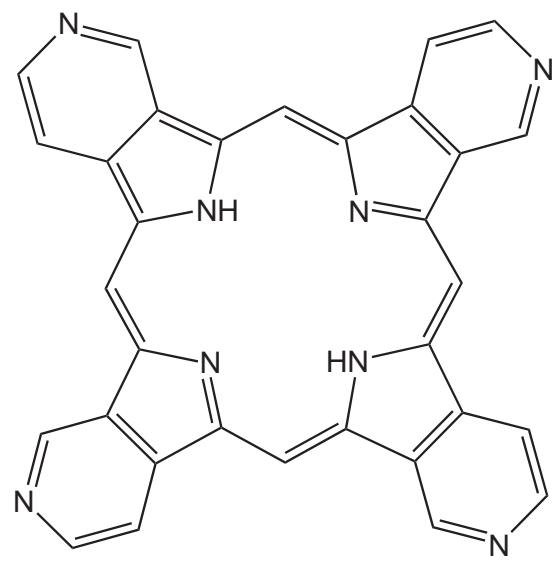

4-TPyPz

Figura 1.6: Exemplos de alguns ligantes comumente utilizados na síntese de complexos supermoleculares. 


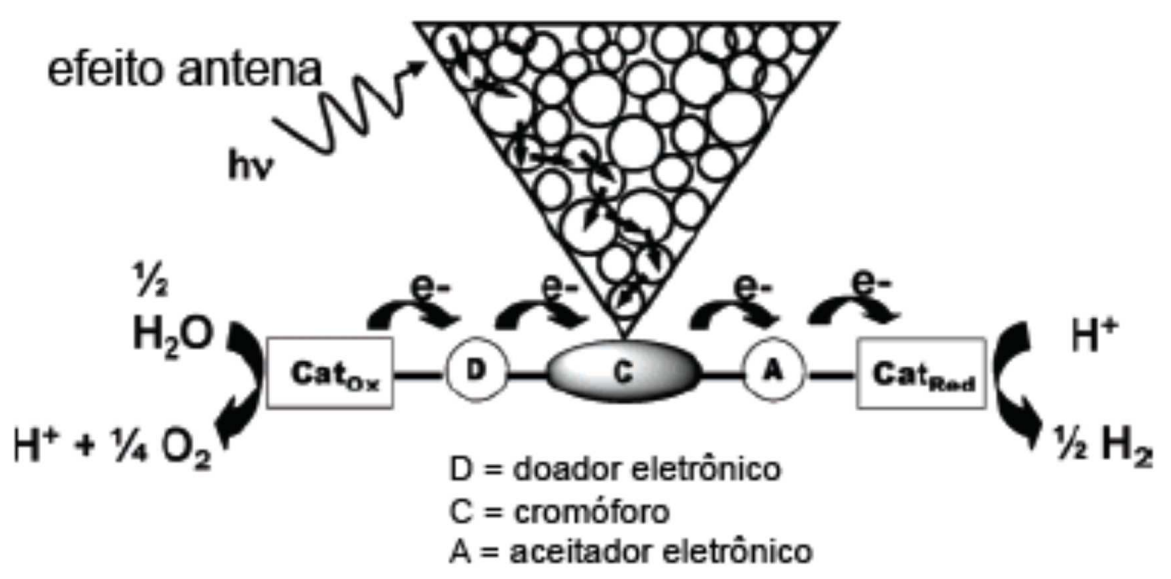

Figura 1.7: Diagrama simplificado dos elementos necessários para um aparato fotossintético artificial. Efeito antena e eventos que ocorrem após absorção de luz, levando a fotodecomposição da água em $\mathrm{H}_{2}$ e $\mathrm{O}_{2}$ [7].

que se proponham a realizar a fotossíntese artificial, são necessários pelo menos três componentes miméticos, capazes de: a) imitar a captação da luz (efeito antena) realizada pela clorofila, carotenos e outros pigmentos; b) promover a separação de cargas e c) realizar os processos redox, de forma análoga ao executado pelos fotossistemas I e II [24, pp.96-167] [42-44]. A figura 1.7, adaptada de Meyer et al. [7], apresenta um esquema destas etapas.

No fotossistema II, por exemplo, a água é oxidada por meio de eventos contínuos de excitação eletrônica e separação de cargas, de modo que a fotoexcitação das biomoléculas é acoplada a oxidação tetraeletrônica da água. Apesar do processo ocorrer num sentido termodinamicamente desfavorável, o arranjo adotado pelo aparato fotossintético leva as reações reversas (recombinações) a caírem na região invertida de Marcus [44,45], favorecendo assim os processos de separação de carga em contraposição aos processos de recombinação.

Outra característica importante responsável pela grande eficiência da fotossíntese é o processo de transferência de energia vetorial dos cromóforos vizinhos para o par especial, através do efeito antena (figura 1.7). 


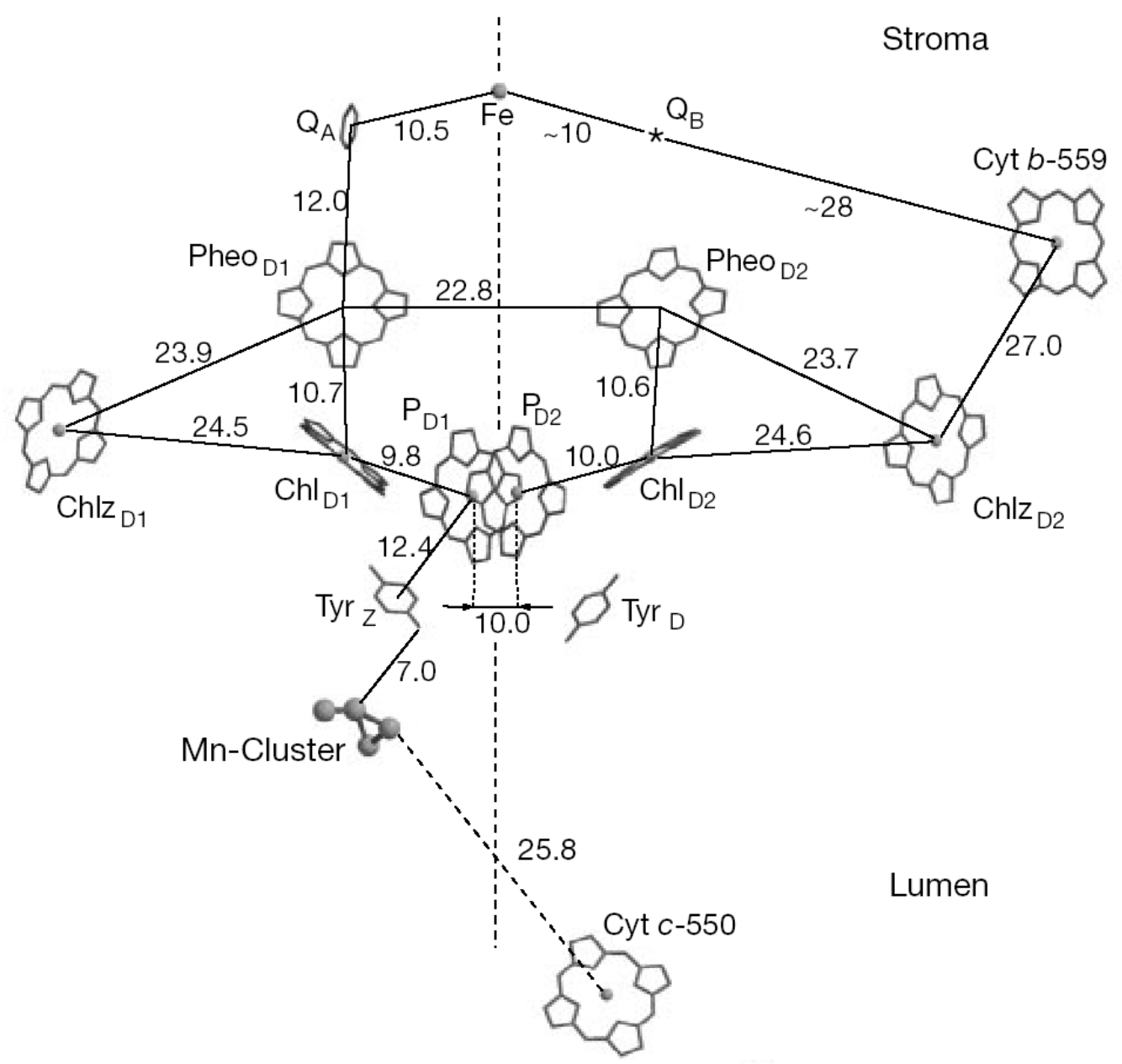

Figura 1.8: Arranjo dos cofatores e do par especial no PSII. Os números indicam a distância em $\AA[8]$.

Por causa dessas duas funções chave, um sistema mimético apto a realizar o transporte de elétrons deve possuir estados excitados de longa vida e permitir um controle adequado da estabilidade relativa dos estados espectroscópicos fundamentais e excitados. A separação e a orientação espacial dos componentes são também fatores cruciais para que ocorra a separação de cargas e a acumulação química de energia via processos redox. Veja por exemplo a estrutura do PSII resolvida a 3,8 $\AA$ por difração de raios-X no artigo de P. Orth et al. [8] e reproduzido em parte na figura 1.8.

O tempo de vida do estado excitado é normalmente controlado pela escolha do íon metálico e os ajustes finos são dados pela escolha dos ligantes. Nesses sistemas os ligantes atuam como conectores para controlar a orientação e a distância entre as 
subunidades, colocando os centros metálicos em posições designadas e a distâncias fixas, o que viabiliza a obtenção da arquitetura molecular desejada.

Os progressos nesta área ainda permanecem em grande parte limitados pelas dificuldades sintéticas, uma vez que quando o número e tipos de componentes crescem, o nível de complexidade também aumenta. Mas os esforços coletivos de vários grupos de pesquisa e os métodos da química supramolecular têm levado a vários modelos engenhosos de centros reacionais, além disso, a sofisticação das espécies sintéticas multicomponentes que imitam os eventos primários da fotossíntese vem crescendo gradualmente $[7,24,42,46-56]$.

Além dos requisitos sintéticos e espectroscópicos, um segundo problema fundamental na conversão fotoquímica da energia solar consiste em alcançar-se os potenciais requeridos com luz visível e reproduzir os eventos de excitação eletrônica acoplados a separação de cargas. Isto porque a transferência de elétrons fotoinduzida é um processo de um elétron, enquanto que todas as reações químicas que se espera envolver na conversão artificial da energia solar são processos multieletrônicos. Isto significa que os componentes capazes de sofrer transferência eletrônica fotoinduzida devem ser acoplados a componentes capazes de armazenar elétrons e usá-los em processos redox multieletrônicos.

Um exemplo biomimético capaz de combinar algumas destas funções foi relatado em um dos trabalhos desenvolvido por Gust, Moore et al. sobre fotossíntese artificial [9], o qual está ilustrado na figura 1.9.

Neste exemplo, a supermolécula formada pela tríade caroteno-porfirina-naftoquinona atua como um sistema doador-espaçador-aceptor, formando a espécie $\mathrm{C}^{+}-\mathrm{P}-\mathrm{Q}^{-}$ quando excitada pela luz visível. A tríade $\mathrm{C}^{+}-\mathrm{P}-\mathrm{Q}^{-}$por sua vez promove transferência de elétrons fotoinduzida, gerando a força motriz de prótons (pmf) necessária para alimentar a enzima $\mathrm{CF}_{0} \mathrm{~F}_{1}$ ATP sintase, responsável pela síntese de ATP. Segundo os autores, o rendimento quântico final é superior a $7 \%$. 


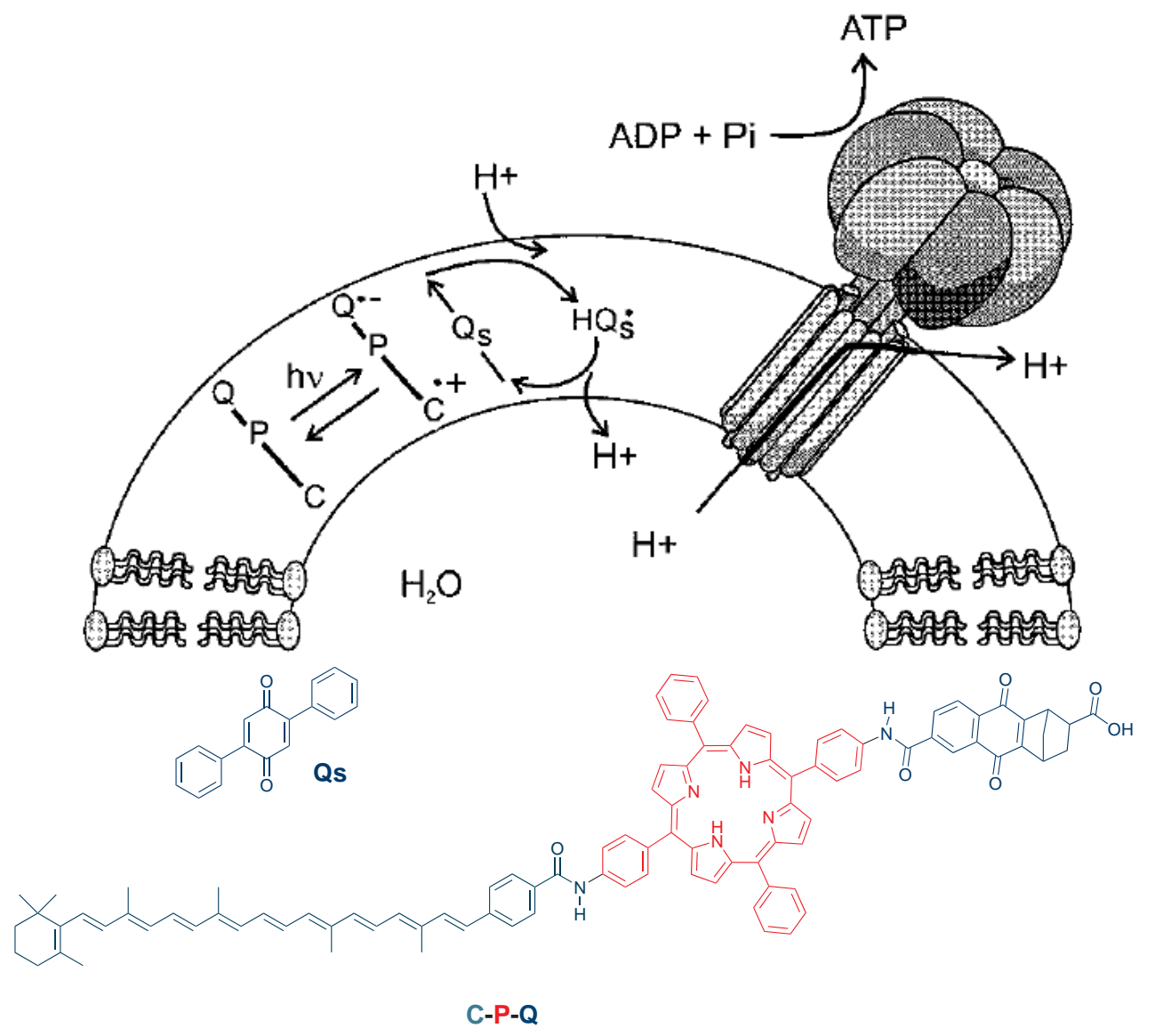

Figura 1.9: Esquema da membrana fotossintética artificial onde é ilustrado o mecanismo de transporte foto-induzido de prótons [9]. 


\subsubsection{Aspectos Conceituais e Sintéticos}

Com o advento da química supramolecular um grande esforço foi e está sendo direcionado ao desenvolvimento de estratégias sintéticas versáteis e seletivas para a preparação de espécies supramoleculares.

Um dos métodos mais utilizados nestas sínteses emprega a estratégia complexos como metais/complexos como ligantes [40,57].

Nesse método, parte-se da síntese de compostos de coordenação mononucleares pela combinação do íon metálico com os ligantes livres, e a seguir combina-se esses novos complexos com outros ligantes ou complexos que contenham sítios de coordenação livres em sua estrutura. Nesse segundo nível de organização, os ligantes podem ser do tipo ponte, dando origem a estruturas oligoméricas, serem de caráter central, dando origem a estruturas polinucleares como as obtidas com os complexos supermoleculares de porfirinas [58] ou serem ainda de caráter terminal, fechando os sítios de coordenação remanescentes.

Aplicando a equação 1.1 para o exemplo (c) da figura 1.10 podemos dizer que os clusters de $\mathrm{Ru}(\mathrm{II})$ se comportaram como $\mathrm{M}$ e a tetrapiridilporfirina se comportou como L. Vemos também nos exemplos da figura 1.10 que através dessa estratégia simples pode-se chegar a estruturas polinucleares oligoméricas que contenham mais de uma dezena de centros metálicos [59-62].

$$
M+n L \rightarrow M(L) n
$$

Quanto ao conceito, uma certa ambigüidade ainda reside em definir uma dada espécie como sendo uma estrutura supramolecular ou uma molécula grande. Neste sentido, Balzani e colaboradores [40] propuseram uma conceito simples e objetivo, apresentado na figura $1.11[63,64]$.

Segundo este critério fotoquímico e eletroquímico, uma espécie supramolecular é definida como um sistema complexo constituído de componentes moleculares com pro- 


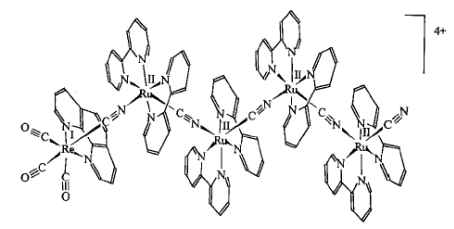

(a)

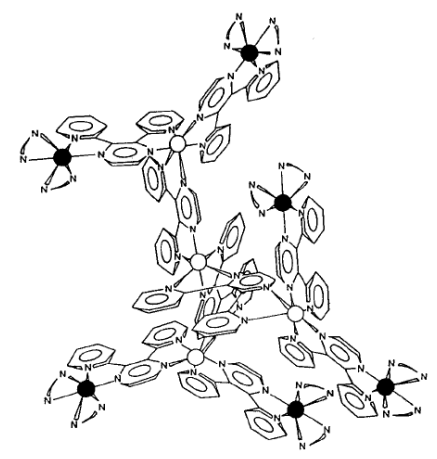

(c)

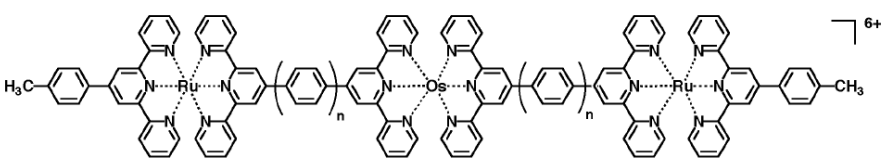

(b)

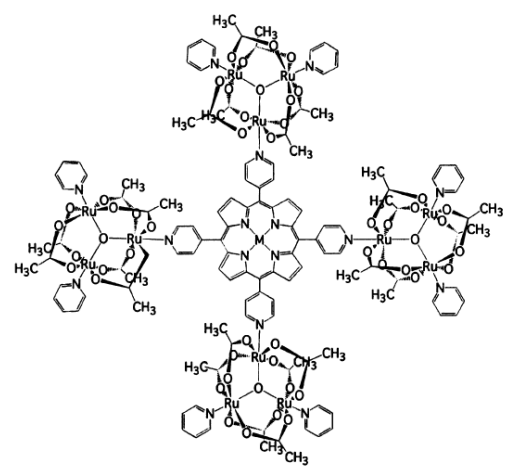

(d)

Figura 1.10: (a) e (b) Complexos polinclueares de $\mathrm{Ru}(\mathrm{II}), \mathrm{Re}(\mathrm{I})$ e $\mathrm{Os}(\mathrm{III})$ coordenados a terpy e bipy e conectados por grupos ponte cianeto e fenileno. c) Complexo decanuclear de Ru(II) (esferas claras) e Os(III) (esferas escuras) coordenados a dpp e bipy e d) Supermolécula obtida pela coordenação de clusters de Ru(II,III) a TPyP.

\begin{tabular}{|c|c|c|}
\hline $\begin{array}{l}\text { espécie } \\
\text { supramolecular }\end{array}$ & composto & molécula grande \\
\hline $\left.\begin{array}{c}{ }^{*} A \sim B \\
A \sim{ }^{*} B\end{array}\right)$ & & \\
\hline $\left.\begin{array}{l}A^{+} \sim B^{-} \\
A^{-} \sim B^{+}\end{array}\right\}$ & $A \sim B$ & ${ }^{*}(A \sim B)$ \\
\hline $\begin{array}{l}A \sim B^{-1} \\
A \sim B^{-}\end{array}$ & $A \sim B$ & $(A \sim B)^{-}$ \\
\hline $\begin{array}{l}A^{+} \sim B \\
A \sim B^{+}\end{array}$ & $A \sim B$ & $(A \sim B)^{+}$ \\
\hline
\end{tabular}

Figura 1.11: Ilustração do critério fotoquímico e eletroquímico para classificar uma espécie química complexa como supramolecular ou molécula grande (o símbolo indica qualquer interação química que mantenha A e B ligados. 
priedades individuais definidas [63,64]. Como demonstrado no esquema da figura 1.11, a excitação fotônica da espécie supramolecular $\mathrm{A}^{\sim} \mathrm{B}$ leva a estados excitados que estão substancialmente concentrados sobre o componente A ou B. Quando o estado excitado está substancialmente deslocalizado sobre A e B a espécie é melhor tratada como uma molécula grande.

Transferindo essa definição para um caso prático, onde tomamos os complexos de valência mista como exemplo, observa-se que somente serão considerados como supramoleculares os complexos do tipo I e II [65], pois apresentam baixo acoplamento eletrônico entre os constituintes; enquanto que os complexos do tipo III são melhor tratados como moléculas grandes (os fatores que determinam a natureza localizada ou deslocalizada do estado excitado podem ser avaliados pelo formalismo de Hush [66]).

De acordo com este conceito as espécies polimetaladas de porfirina que serão discutidas a seguir se comportam como espécies supramoleculares. Porém, para fins de clareza, preferiu-se adotar neste trabalho o termo supermolecular para os complexos polinucleares de porfirina e supramolecular para os arranjos obtidos a partir destas espécies.

\subsection{Sistemas Supramoleculares de Porfirinas}

Existe na literatura uma série extensa de sistemas supramoleculares constituídos por compostos porfirínicos, ftalocianinas, clusters, calixarenos e complexos poliimínicos $[1,22,41,58]$. Nosso interesse está voltado aos sistemas supramoleculares de porfirinas, mais especificamente, tetrapiridilporfirinas. Isto porque sistemas sintéticos baseados nesses macrociclos são largamente empregados como modelos de organização molecular e processos de transferência de energia e de elétrons, sendo que seus complexos podem dar origem a materiais eletroquímica, fotoeletroquímica e eletrocatalicamente ativos.

As porfirinas são grupos prostéticos importantes num vasto número de metaloproteínas e metaloenzimas e são proximamente relacionadas aos pigmentos tetrapirrólicos 
macrocíclicos que ocorrem nos centros reacionais naturais $[43,44,67]$. Suas ricas propriedades fotofísicas, fotoquímicas e eletroquímicas aliadas a uma grande versatilidade sintética impulsionaram um grande número de pesquisas envolvendo esses compostos como unidades precursoras na preparação de sistemas supramoleculares ou estudadas isoladamente na forma metalada ou base-livre.

Um dos principais apelos nestas pesquisas é a possibilidade de se modular - "sintonizaras propriedades das porfirinas por metalação ou coordenação aos ligantes exocíclicos, pois as propriedades do anel são sensíveis a essas interações. Imagine por exemplo o efeito que teria sobre a atividade da hemoglobina a substituição de Fe(II) pelo íon Zn(II) no centro metálico do grupo heme desta biomolécula, levando a mesma a perder a capacidade de transporte de oxigênio.

\subsubsection{Complexos com Rutênio}

Tetrapiridilporfirinas tetracoordenadas a grupos como $\left[\mathrm{Ru}(\text { bipy })_{2} \mathrm{Cl}_{2}\right]^{2+},[\mathrm{Ru}(\text { edta })]^{-}$, $\left[\mathrm{Ru}\left(\mathrm{NH}_{3}\right)_{5}\right]^{2+},\left[\mu-\mathrm{O}-\mathrm{Ru}_{3}\left(\mathrm{CH}_{3} \mathrm{COO}\right)_{6}(\mathrm{py})_{2}\right]^{+},\left[\mathrm{Fe}(\mathrm{CN})_{5}\right]^{3-}$, têm sido motivo de extensas investigações por parte do Laboratório de Química Supramolecular e Nanotecnologia. Especialmente nos últimos 15 anos esse grupo vem investigando a síntese, caracterização e aplicação de sistemas supramoleculares obtidos a partir dessas espécies $[10,41,60,62,68-99]$. A figura 1.12 apresenta alguns exemplos para esta classe de supermoléculas, que foram desenvolvidos no grupo de pesquisa.

Os principais objetivos destas pesquisas consistem em conjugar as propriedades fotoquímicas, catalíticas e a versatilidade sintética das porfirinas e metaloporfirinas com as propriedades fotoquímicas e eletroquímicas dos complexos metálicos coordenados na periferia do anel. Complexos moleculares e supramoleculares dessa classe já demonstraram a capacidade de atuarem como sensores eletroquímicos [75, 83, 93, 100-104], filmes condutores e fotocondutores $[86,87,104]$, sensibilizadores para células solares fotoeletroquímicas e sistemas miméticos da fotossíntese [10, 105], em eletrocatálise [60, 72, 89, 97, 106-110] e de interagiram com DNA, com potencial aplicação em te- 


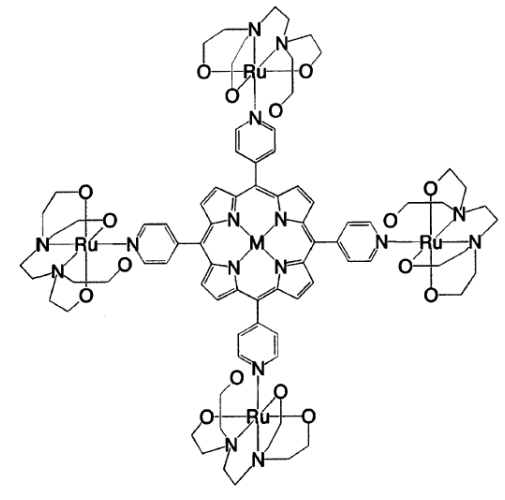

(a)

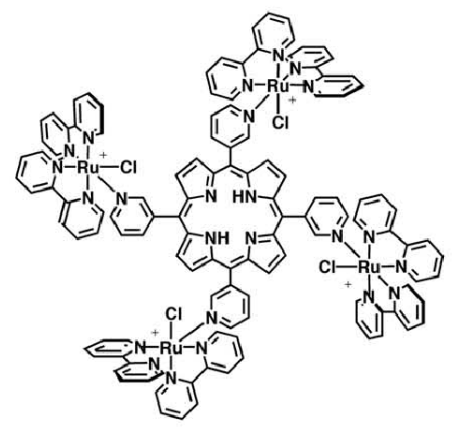

(c)

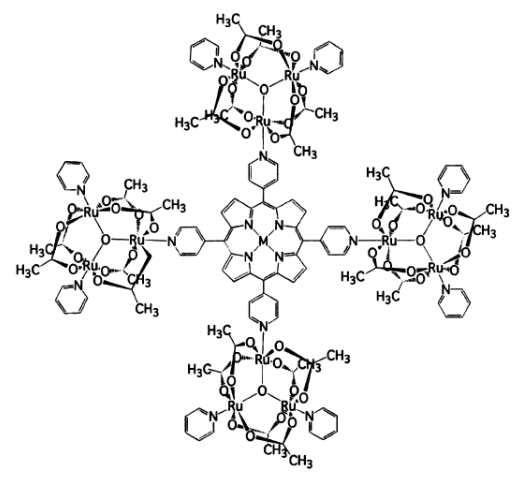

(e)

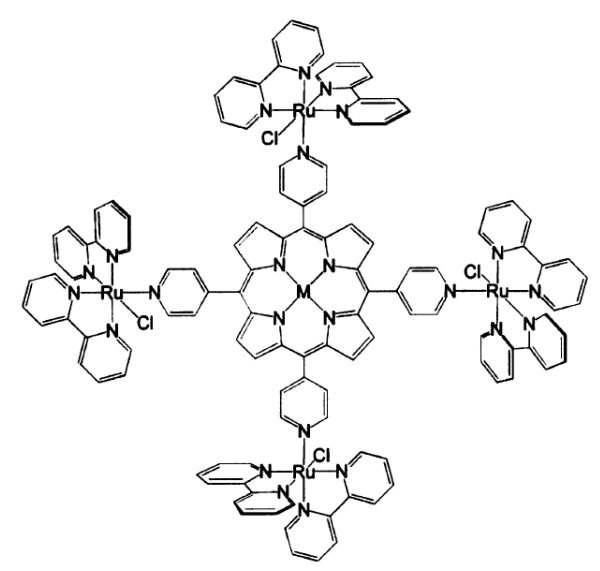

(b)

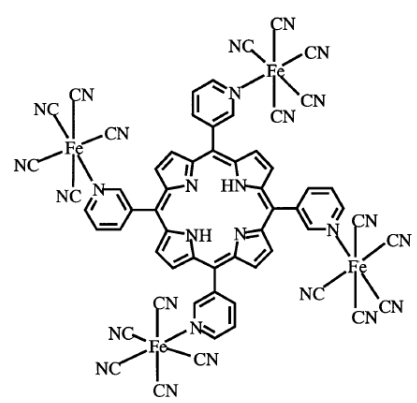

(d)

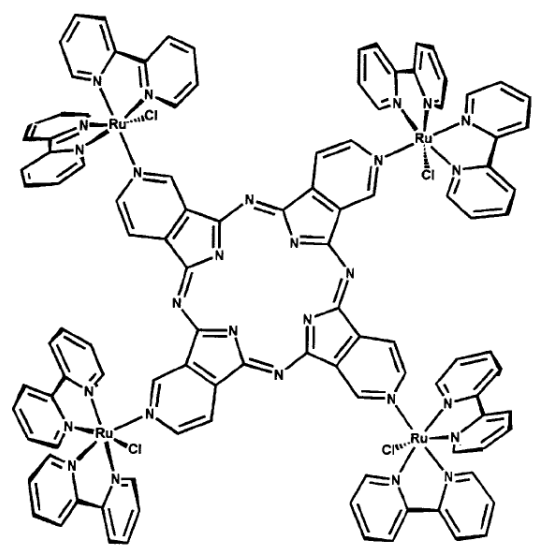

(f)

Figura 1.12: Estrutura das supermoléculas de tetrapiridilporfirinas tetracoordenadas a complexos de rutênio e ferro. 
rapia fotodinâmica $[77,85]$.

Em termos de modulação de propriedades, o que se observa nessas supermoléculas é que os complexos auxiliares coordenados exociclicamente podem tanto modificar o ambiente local ao redor da porfirina, alterando as propriedades de solvatação e solubilidade, ou se comportarem como cofatores nos processos redox, provisionando sítios doadores-aceitadores de elétrons $[60,95,108,111]$. Os complexos auxiliares podem ainda modificar a atividade intrínseca do centro metaloporfirínico por meio de interações eletrônicas e contribuir com sítios adicionais para interações intermoleculares e intramoleculares, permitindo a montagem de espécies supramoleculares nanoscópicas.

Porfirinas de ferro e manganês por exemplo têm sido extensivamente estudadas como modelos biomiméticos do citocromo P-450 [112,113] porque atuam como catalisadores de transferência de átomos de oxigênio de iodosilarenos e óxidos de aminas terciárias para hidrocarbonetos, produzindo epóxidos a partir de alcenos e álcoois a partir de alcanos. A espécie ativa nesses casos consiste de metaloporfirinas com oxometais de alta valência, usualmente manganês(III). Nesses casos, a atividade catalítica de oxo-manganês porfirinas aumenta com a ligação de complexos poliimínicos e clusters de rutênio nos grupos meso-piridil [60, 95, 97].

Por outro lado porfirinas de zinco(II) são particularmente apropriadas para explorarse a energia contida nos fótons, sendo aptas a mimetizarem o efeito antena da fotossínteses. Na supermolécula ZnTRP (figura 1.13a), o estado singlete $\mathrm{S}_{1}$ da parte TPyPZn é energeticamente próximo ao ${ }^{3} \mathrm{MLCT}$ dos complexos de $\mathrm{Ru}(\mathrm{II})$. Desse modo, uma pequena perturbação nos níveis de energia desses orbitais torna possível o processo de transferência de elétrons entre essas duas partes. Segundo os autores, esse efeito é alcançado pela coordenação axial de imidazol ao íon central Zn(II), o que promove um pequeno decréscimo neste gradiente de energia, habilitando a transferência eletrônica $\mathrm{Ru} \rightarrow \mathrm{TPyPZn}$.

Complexos supermoleculares de porfirinas são muito úteis também na preparação de filmes moleculares, os quais são aplicados principalmente na modificação química de 
eletrodos. O processo de modificação se dá pela imobilização dos filmes na superfície do eletrodo, os quais podem ser gerados por métodos de dip-coating, auto-organização eletrostática ou eletropolimerização, conforme discutido na próxima seção (página 22). Obtêm-se assim filmes finos, aderentes e nanoestruturados, como revelam os estudos por SPM $[96,114]$.

Filmes de ZnTRu(bipy)P e ZnTRu(phen)P já foram ancorados na superfície de $\mathrm{TiO}_{2}$ nanocristalino para atuarem como sensibilizadores em células solares fotoeletroquímicas, alcançando um IPCE de até 13\% na região da banda Soret da supermolécula [10]. A estrutura dessas supermoléculas e o gráfico de IPCE para a espécie mais ativa são apresentadas na figura 1.13. Essas investigações indicam que o ancoramento na superfície do semicondutor se dá através do centro porfirínico da supermolécula, provavelmente por interações entre o íon $\mathrm{Zn}(\mathrm{II})$ com grupos hidroxílicos do $\mathrm{TiO}_{2}$. 


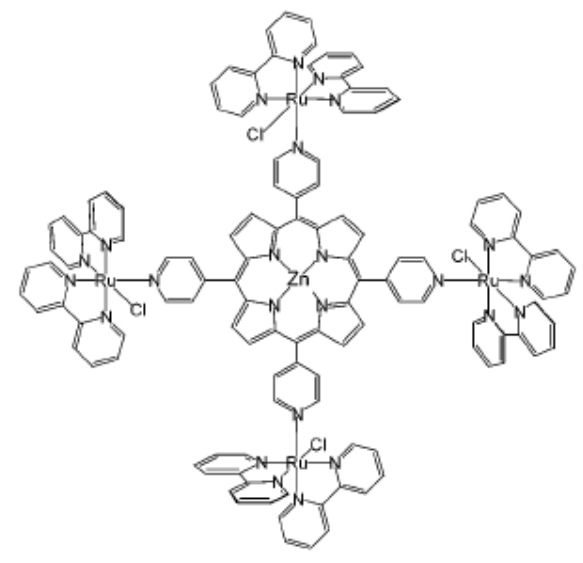

(a)

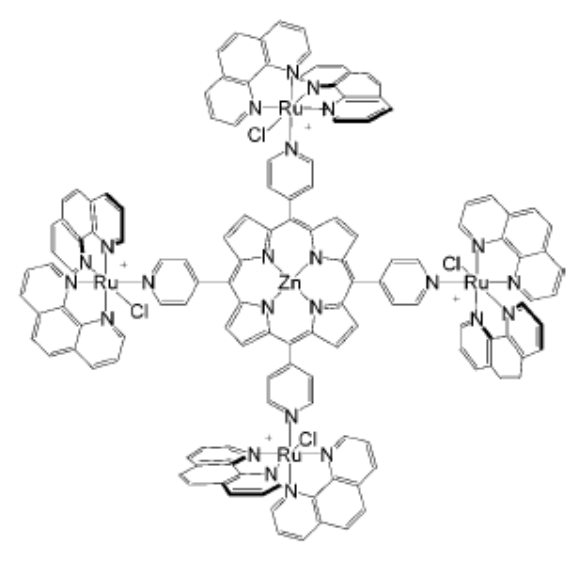

(b)

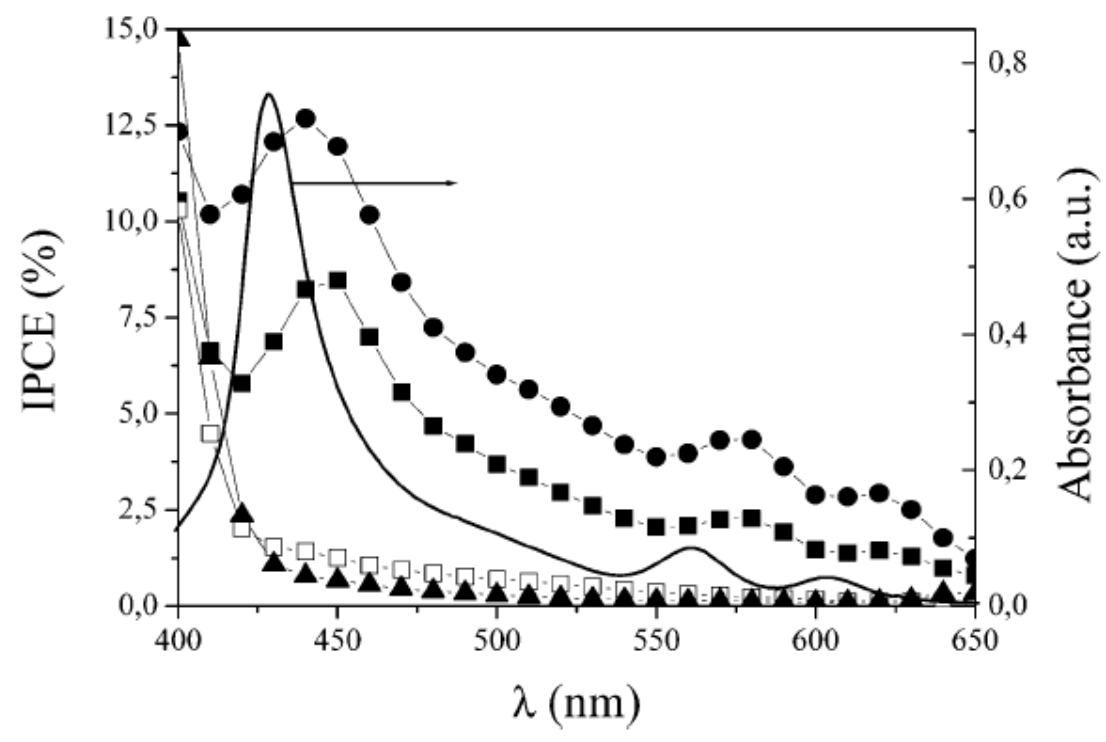

(c)

Figura 1.13: (a) Representação estrutural da TRu(bipy)TPyPZn e (b) $\mathrm{TRu}\left(\right.$ phen)TPyPZn. (c) Curva IPCE para os dispositivos $\mathrm{TiO}_{2} / \mathrm{TRu}$ (bipy)TPyPZn

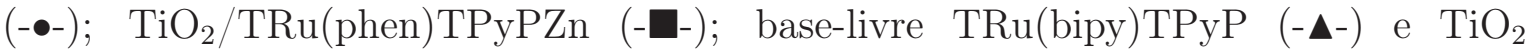
sem sensibilizador(- $\square-$ ). A linha sólida corresponde ao espectro de absorção da TRu(bipy)TPyPZn em MeCN [10]. 


\subsubsection{Pares Iônicos Supramoleculares}

Conforme estabelecem Drain et al. [115] e Araki et al. [76], alguns fatores críticos a serem considerados para materiais moleculares obtidos por auto-montagem são: 1) A grande maioria dos processos são conduzidos em solução, usando as vezes forças intermoleculares fracas. Neste caso, estes produtos manterão a estrutura e a função desejada se forem depositados em superfícies?; 2)Quão estável são esses sistemas moleculares eletroquimicamente, termicamente e sob exposição a oxigênio? e 3) Como pode-se preparar adequadamente estes sistemas em estado sólido com as propriedades físicas, químicas e fotofísicas desejadas?

Porfirinas, ftalocianinas e compostos macrocíclicos relacionados apresentam uma forte tendência em agregar-se em solução, formando dímeros, trímeros e oligômeros. Quando esta tendência natural é realçada por interações eletrostáticas [62,116,117], os sistemas obtidos tendem a ser bastante estáveis, mantendo as propriedades observadas em solução. Desse modo, esses sistemas respondem bem aos dois primeiros requisitos.

Em relação a terceira questão, várias técnicas foram desenvolvidas para a preparação de filmes finos e homogêneos de porfirinas $[87,118]$, onde o controle camada-por-camada da composição e da espessura constitui um dos maiores desafios.

A preparação de filmes moleculares é um aspecto importante também no desenvolvimento de dispositivos supramoleculares e as técnicas mais conhecidas para a preparação de filmes são: a) A termoevaporação [119,120], bastante apropriada para obtenção de filmes homogêneos, porém, limitada a materias voláteis e termicamente resistentes. b) O método de Langmuir-Blodgett (LB), uma técnica muito útil, mas geralmente restrita a sistemas anfifílicos capazes de formarem monocamadas estáveis em uma superfície líquida [121-123] e c) Filmes preparados por técnicas de dip-coating, spin-coating [124] e eletropolimerização $[125,126]$, este último caso restrito a espécies dotadas de grupos funcionais capazes de habilitar o processo de eletropolimerização, conforme observado no exemplo da referência [127].

Nesse âmbito, a formação de pares iônicos, onde os filmes são preparados pela 
deposição camada-por-camada das espécies opositamente carregadas [76], se mostra como uma estratégia alternativa e relativamente simples, a qual atende adequadamente ao terceiro requisito levantado anteriormente. A figura 1.14 ilustra essa estratégia [90].

As propriedades espectroscópicas das estruturas supramoleculares obtidas por pareamento eletrostático diferem substancialmente dos compostos de partida, onde se observa o surgimento de novas transições eletrônicas. Essas bandas são conhecidas como transferência de carga do par iônico (IPCT) ou transferência de carga de esfera externa (OSCT) $[128,129]$. Por esse motivo a formação de novas espécies associadas é facilmente acompanha por meio dos espectros UV/VIS.

Além da força de atração coulômbica que atua na formação desses sistemas, verificase que a planaridade dos anéis possibilita um contato próximo entre as unidades, levando a interações $\pi-\pi$ que auxiliam na estabilização das estruturas formadas [129]. Inclusive, o número de elétrons $\pi$ nos ligantes parece ser determinante para a energia livre de associação destas espécies [130].

Estudos da literatura indicam ainda que esses sistemas podem permitir transferência de elétron fotoinduzida unidirecional [131,132], atuando como modelos do par especial do centro reacional fotossintético.

Para os complexos tetracoordenados de porfirinas, verifica-se que pares iônicos supramoleculares envolvendo essas espécies tendem a absorver fortemente em determinadas superfícies. Daí o principal uso explorado até agora, que é a imobilização desses pares iônicos sobre eletrodos para obter-se filmes eletroquimicamente ativos e firmemente aderidos. Essa metodologia tem sido empregada com grande êxito na preparação de sensores eletroquímicos capazes de detectar $\mathrm{SO}_{2}$ em vinhos e nitrito em solução, entre outros analitos $[83,93,127]$.

Eletrodos quimicamente modificados por pares iônicos de Co(II)TPyP tetrametaladas com $\mathrm{Ru}(\mathrm{II})$-diimínas e clusters de acetato de $\mathrm{Ru}(\mathrm{II}, \mathrm{III})$ (figura 1.15), associadas a meso-(tetrasulfonatofenil)porfirinas foram aplicados com sucesso na redução tetraeletrônica de oxigênio [92] e na deteç̧ão amperométrica de nitrito e nitrato [93], onde a 

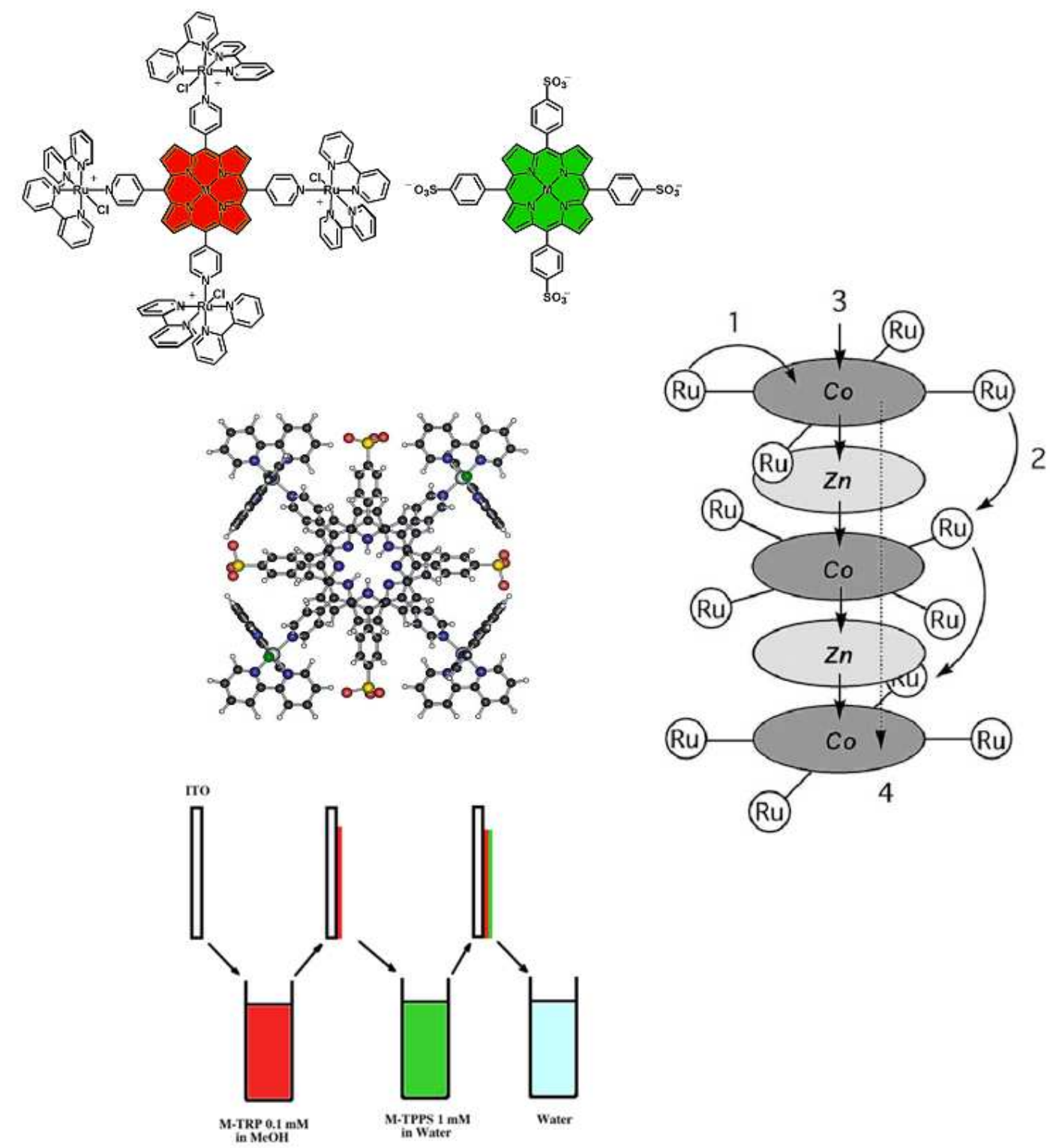

(Ru)

Figura 1.14: Formação de filmes de pares iônicos por dip coating onde é demonstrando o padrão de empilhamento adotado e modelo proposto para o processo de transferência de carga 
supermolécula constitui a espécie ativa e a porfirina aniônica auxilia no ancoramento sobre o eletrodo. Este é, inclusive, o padrão de comportamento observado até o momento para esses pares iônicos depositados sobre eletrodos [133].
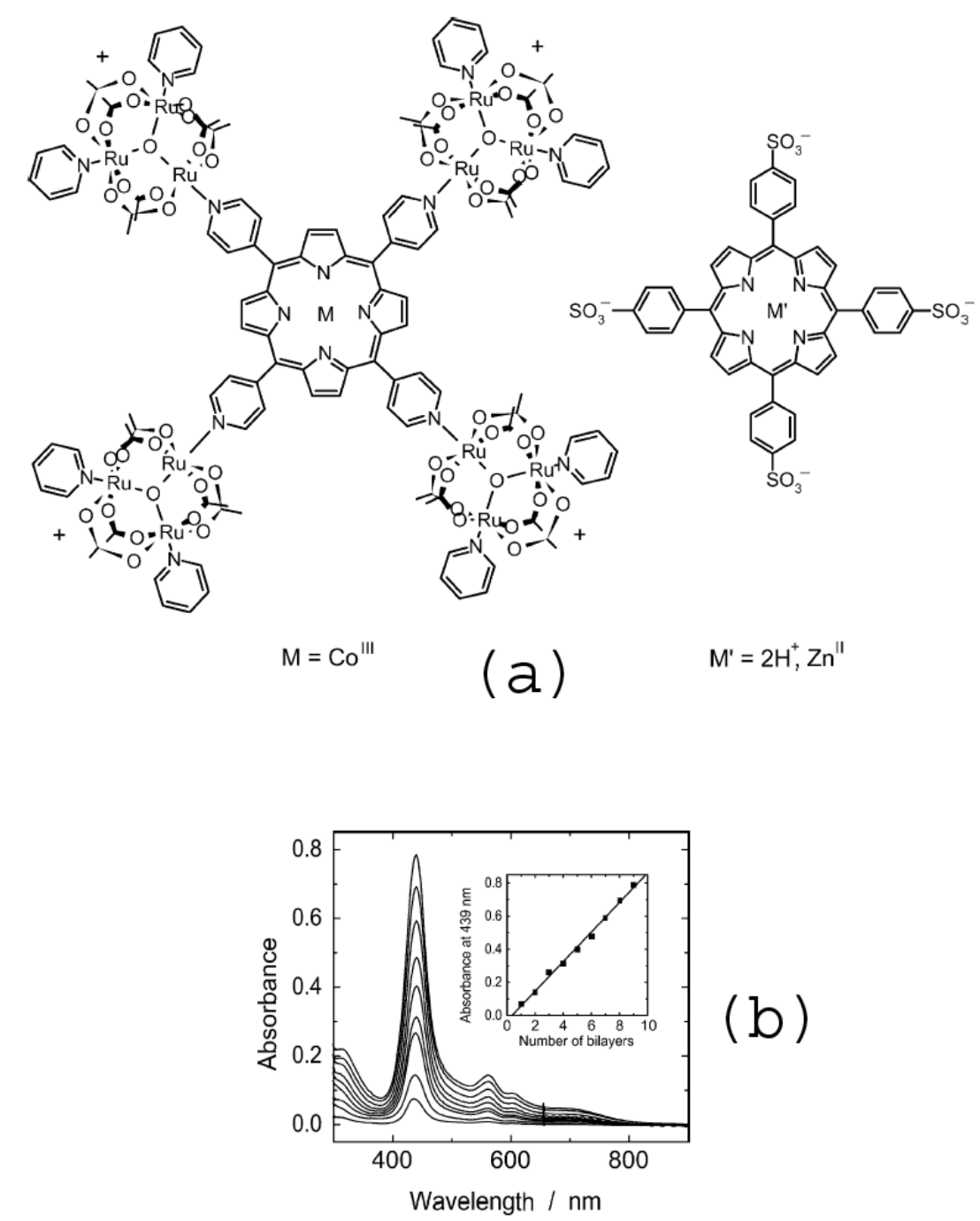

(b)

Figura 1.15: a) Estrutura da CoTCP e ZnTPPS b) Variação do espectro UV-VIS com o número de camadas e plotagem linear da absorvância a $439 \mathrm{~nm}$ em função do número de deposições sucessivas do filme (inserção). 


\subsection{Complexos Diimínicos de Platina}

A química dos complexos de platina(II), especialmente aqueles formados com ligantes diimínicos, é voltada em sua maior parte ao estudo da atividade biológica, ao modo de interação com biomoléculas e às suas peculiares propriedades espectroscópicas e fotofísicas. Estes serão os temas abordados nos tópicos a seguir.

\subsubsection{Interação com Biomoléculas}

Com a descoberta da atividade antitumoral da cisplatina (figura 1.16) por Rosenberg [134] em 1969, uma grande atenção foi dada ao estudo do comportamento dos complexos de platina(II) substituídos.

A cisplatina é ativa contra vários tipos de tumores, sendo empregada no tratamento de câncer de ovário, testicular, cabeça e pescoço [135]. Em função dessa atividade, as pesquisas que se sucederam após 1969 se dividiram em duas linhas temáticas principais [136]: a) uma grande gama de complexos de Pt(II) foi sintetizado e testada em relação a sua potencial atividade biológica no tratamento de outros tumores, o que levou a descoberta de outras espécies ativas como a carboplatina, figura 1.16 e b) investigações sistemáticas foram realizadas para determinar os fatores que controlam a reatividade (labilidade) dos complexos de Pt(II) [137-143].

Com isso percebeu-se que os compostos antitumorais de platina mais ativos são do tipo $\mathrm{L}_{2} \mathrm{PtX}_{2}$, onde $\mathrm{L}$ corresponde a grupos inertes (no leaving groups) e $\mathrm{X}$ corresponde a grupos lábeis (leaving groups). No interior da célula os ligantes tipo X são substituidos por água e depois por nucleófilos do DNA e os ligantes do tipo L permanecem coordenados a platina(II). Grupos L típicos são amônia e aminas e grupos X usuais são cloretos ou carboxilatos [144,145]. Ou seja, a atividade biológica desses compostos é devida à habilidade que os complexos de platina(II) tem de ligar-se com biomoléculas.

Além de ligarem-se coordenativamente a base nucléicas, preferencialmente a resíduos de guanina, os complexos de platina(II) também interagem por metalointer- 
<smiles>N[PH](N)(Cl)Cl</smiles>

(a)<smiles>N[Pb](N)(N)OC(=O)C1(C(=O)O)CCC1</smiles>

(b)

Figura 1.16: Estrutura da cis-platina (a) e carboplatina (b).

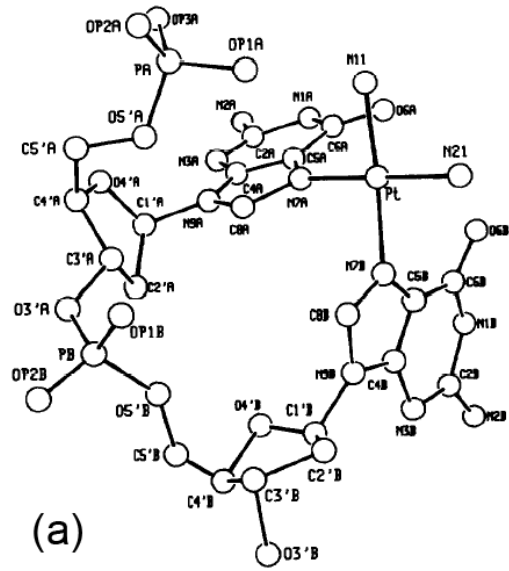

(b)

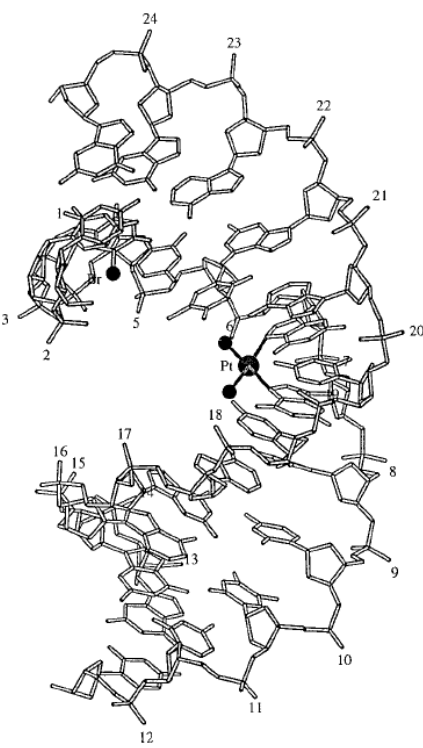

Figura 1.17: (a) Estrutura do aduto cis- $\left[\mathrm{Pt}\left(\mathrm{NH}_{3}\right)_{2}\{\mathrm{~d}(\mathrm{pGpG})\}\right]$. (b) Projeção do aduto ao longo da cadeia.

calação, especialmente os derivados diimínicos como [Pt(terpy)L]X [138]. Quando atuam como metalointercaladores estes se inserem entre as bases da dupla hélice do DNA [146, 147]. A figura 1.17 traz a estrutura cristalina do fragmento $\mathrm{Pt}\left(\mathrm{NH}_{3}\right)^{2+}$ coordenado ao DNA em dois sítios de guanina [148,149]. Na figura 1.18 tem-se o modelo de intercalação dos complexos polipiridínicos de platina(II) entre os pares de base da dupla hélice $[138,150,151]$ e o efeito que esta interação causa sobre o arranjo espacial da cadeia duplamente entrelaçada do DNA.

A exploração dessas propriedades tem valor não só no sentido de obter-se novos quimioterápicos, mas também no estudo de aspectos estruturais e funcionais de metaloproteínas e ácidos nucléicos $[137,138,152]$. Neste tipo de aplicação, os complexos metálicos podem atuar como modelos funcionais dos centros ativos de proteínas. Pela 


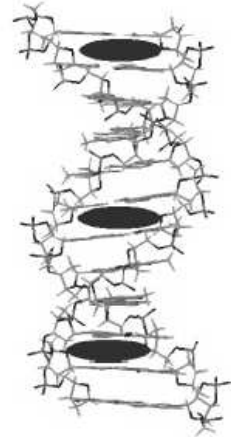

(a)
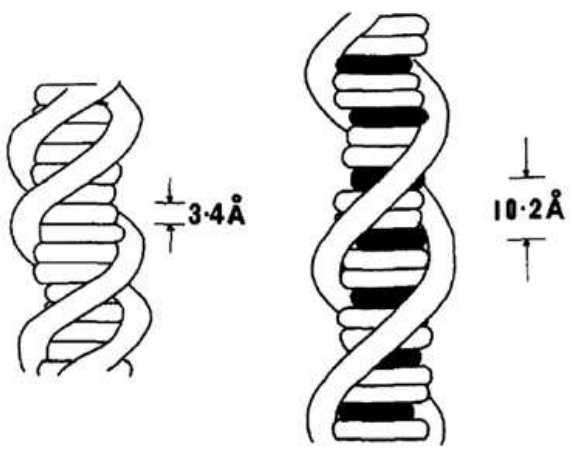

(b)

Figura 1.18: (a) Modelo da intercalação de PtL ( $\mathrm{L}=$ terpy, bipy ou phen) e (b) efeito da intercalação sobre a distância entre os pares de base na dupla hélice.

inserção de um centro metálico espectroscopicamente ativo numa biomolécula, pode-se obter informações sobre a dinâmica e a estrutura do meio. Desse modo, a compreensão dos mecanismos de interação como também a investigação do efeito desta interação sobre as propriedades espectroscópicas podem levar ao desenvolvimento de agentes de diagnósticos altamente sensíveis e seletivos [152].

Nessa direção, complexos metálicos fotoluminescentes podem ser planejados de forma a possuírem tempos de vida longo em solução fluida, excitação e emissão por luz visível e modos de ligação versáteis com biomoléculas [153]. Levando-se em conta que o rendimento quântico de luminescência e o tempo de vida do estado excitado é sensível ao meio, eles podem ser usados para sondar a estrutura e a dinâmica de uma biomolécula hospedeira como o DNA, conforme mencionado acima. O caráter luminescente pode ser empregado ainda para avaliar processos de transferência de energia e de elétrons envolvendo DNA e proteínas [153].

$\mathrm{O}$ complexo $[\mathrm{Pt}(\text { terpy }) \mathrm{OH}]^{+}$por exemplo, interage com ácidos nucléicos tanto por intercalação como por modo covalente $[146,147,154]$. Quando ele intercala no DNA ocorre um forte aumento na intensidade da fosforescência por transferência de carga metal-ligante ( $\left.{ }^{3} \mathrm{MLCT}\right)$, e esse efeito é atribuído a proteção dos sítios de coordenação axiais [153]. Já quando a interação se dá pela substituição do grupo $\mathrm{OH}^{-}$, com a 
Pt ligando-se próximo a um resíduo de guanina, a emissão ${ }^{3}$ MLCT é completamente suprimida, um efeito atribuído a transferência de elétrons fotoinduzida da guanina para o estado excitado do complexo [154].

\subsubsection{Propriedades Espectroscópicas e Fotofísicas}

De forma geral, complexos imínicos de Pt(II) em solução fluida a temperatura ambiente (t.a.) são não emissivos, mas apresentam emissão no estado sólido ou na forma de soluções vítreas a baixas temperaturas $[155,156]$. A [Pt(bipy) $\left.\mathrm{Cl}_{2}\right]$, por exemplo, não emite a temperatura ambiente em solução de MeCN, mas observa-se fotoluminescência no estado sólido e a solução vítrea exibe perfis de emissão dependentes da concentração [156]. Observa-se ainda que tão logo essas soluções alcancem a temperatura de transição vítrea, a emissão é suprimida [155].

Esse comportamento é atribuído à ocorrência de modos de decaimento não radiativo envolvendo interações do solvente com os sítios de coordenação axiais livres na geometria quadrado-planar d ${ }^{8}[156,157]$. Esses complexos também sofrem auto-supressão em solução e as interações metal-metal e $\pi-\pi$ parecem ser a base desse efeito. Acredita-se que a auto-supressão do estado emissivo ocorre pela associação entre o estado excitado e o estado fundamental de duas moléculas vizinhas na solução [158]. Essas duas características deixam claro que os sítios de coordenação abertos tem uma forte influência sobre o perfil fotofísico e fotoquímico dos complexos $\mathrm{d}^{8}$ de platina.

Investigações sobre a labilidade dos ligantes coordenados à platina demonstram também que a presença de impedimento estérico acima e abaixo do plano quadradoplanar diminui significativamente a taxa das reações de substituição. Já o aumento da população no plano do complexo resultam em aumento da reatividade [136, 159].

Estudos espectroscópicos somados a cálculos teóricos reportados na literatura indicam que os estados excitados d-d e MLCT são muito próximos em energia, resultando em rápidas conversões internas entre esses dois estados. Ou seja, os estados excitados d-d de baixa energia provêem caminhos não-radiativos para o decaimento [160]. 
Segundo C.-H. Tung et al. [160], a principal estratégia para se construir complexos de Pt(II) com estados excitados de vida longa e emissivos em solução a t.a. consiste em utilizar-se ligantes imínicos com LUMO de baixa energia e/ou ligantes auxiliares com forte caráter doador de elétrons, de forma a elevar o nível energético do HOMO do centro metálico, o que resultaria na redução da energia do estado excitado MLCT. Como conseqüência, a diferença de energia entre MLCT e d-d aumentaria, diminuindo o decaimento não radiativo via estados d-d. Seguindo esta hipótese, eles sintetizaram complexos terpiridínicos de $\mathrm{Pt}(\mathrm{II})$ tipo $[\mathrm{Pt}(\mathrm{R}$-terpy $)(\mathrm{C} \equiv \mathrm{C}$-R $)]$ que apresentaram $\Phi_{e m}$ de até 0,30 e $\tau_{\mu}$ de até $14,6 \mu$ s em solução de $\mathrm{CH}_{2} \mathrm{Cl}_{2}$ a $298 \mathrm{~K}$.

Outros estudos conduzidas por McMillin et al. [161] e Che et al. [162] também comprovam esta abordagem, demonstrando que a escolha adequada dos ligantes aniônicos (espécies como $\mathrm{SCN}^{-}, \mathrm{OH}^{-}$e $\mathrm{MeO}^{-}$) levam a estruturas que luminescem em solução. Um segundo efeito promovido pelo aumento do caráter doador dos ligantes é deslocar a banda de emissão para comprimentos de onda maiores em função do aumento na energia do orbital HOMO, centrado no metal, já que a excitação envolve uma transição MLCT [163].

No que concerne às propriedades em estado sólido, sabe-se que os complexos quadradoplanares $\mathrm{d}^{8}$ mostram uma tendência pronunciada em agregar como oligômeros fracamente ligados por interações metal-metal e $\pi$ - $\pi$ entre os ligantes. Espécies mononucleares como $\left[\mathrm{Pt}(\right.$ bipy $\left.) \mathrm{Cl}_{2}\right]$ e $[\mathrm{Pt}($ terpy $) \mathrm{Cl}] \mathrm{ClO}_{4}$ tendem a cristalizar na forma de cadeias lineares, e o sólido, altamente luminescente, é também mais intensamente colorido que a solução dos monômeros [155,164-166]. A explicação para esse comportamento é dada pelos estudos cristalográficos.

As figuras 1.19 e 1.20 apresentam a estrutura cristalina/molecular dos complexos $\left[\mathrm{Pt}\right.$ (bipy) $\left.\mathrm{Cl}_{2}\right]$ e $\left[\mathrm{Pt}\right.$ (terpy) $\mathrm{Cl}_{\mathrm{ClO}} \mathrm{Cl}_{4}$ resolvidas por Textor et al. [11] e Gray et al. $[12,166]$. O que se observa nestes dois sistemas $\mathrm{d}^{8}$ é que eles cristalizam de duas formas diferentes, dando origem a cristais com coloração amarela e vermelha para $\left[\mathrm{Pt}(\right.$ bipy $\left.) \mathrm{Cl}_{2}\right]$ e laranja e vermelha para $[\mathrm{Pt}($ terpy $\left.) \mathrm{Cl}] \mathrm{ClO}_{4}\right)$. 


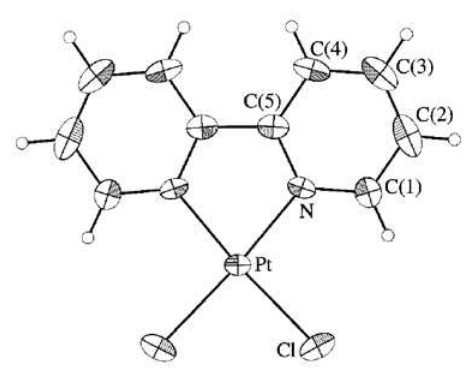

a

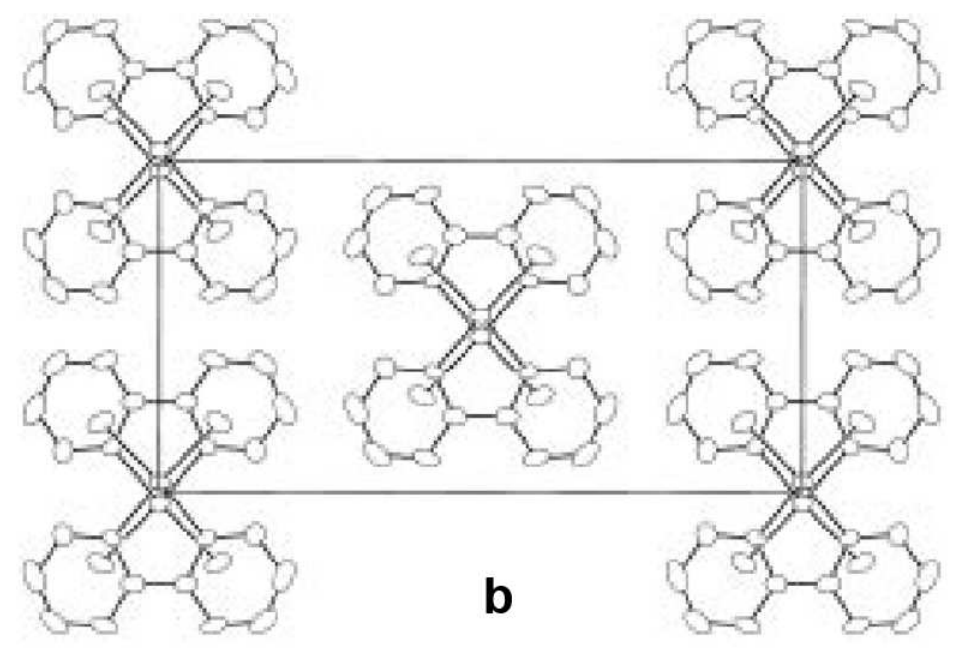

Figura 1.19: a) Diagrama ORTEP da estrutura molecular da $\left[\mathrm{Pt}(\right.$ bipy $\left.) \mathrm{Cl}_{2}\right]$ (nível de probabilidade de $50 \%$ para os elipsóides térmicos dos átomos não hidrogenóides) e b) Projeção do conteúdo da cela cristalina a $294 \mathrm{~K}[11,12]$.

Tomando-se o caso da $\left[\mathrm{Pt}(\right.$ bipy $\left.) \mathrm{Cl}_{2}\right]$ por exemplo, as investigações por difração de raios-X demonstram que ambas as formas pertencem ao mesmo sistema espacial, ortorrômbico, sendo que a única diferença está no modo de empacotamento adotado pelas unidades moleculares na cela espacial. Os cristais vermelhos possuem um padrão de empilhamento com sobreposição das unidades moleculares, formando uma cadeia linear que permite maior aproximação entre os centros metálicos, de modo que as distâncias Pt...Pt são da ordem de 3,4 Å(estrutura da figura 1.19. Já a forma amarela consiste de unidades moleculares isoladas, sem interações significativas entre os centros metálicos, uma vez que a distância Pt... Pt nesse caso é de 4,5 A [11]. O mesmo padrão de empacotamento espacial é observado para os cristais alaranjados e vermelhos da $[\mathrm{Pt}($ terpy $\left.) \mathrm{Cl}] \mathrm{ClO}_{4}\right)$, respectivamente.

Outro fenômeno interessante é que enquanto a forma amarela da $\left[\mathrm{Pt}(\mathrm{bipy}) \mathrm{Cl}_{2}\right]$ é 


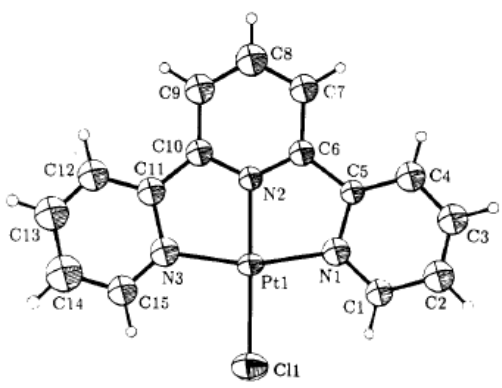

a
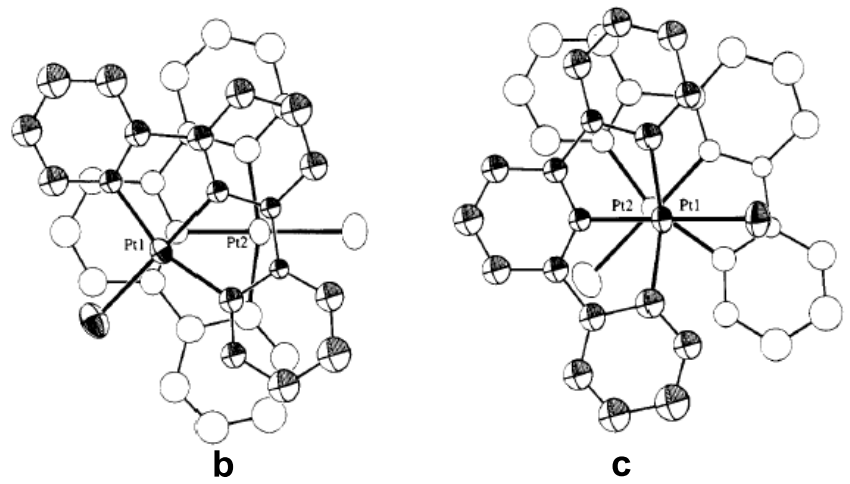

Figura 1.20: Diagrama ORTEP de a) $[\mathrm{Pt}$ (terpy) $\mathrm{Cl}] \mathrm{ClO}_{4}$ e os dois modos de interação cátion-cátion ao longo da cadeia (nível de probabilidade de 50\% para os elipsóides térmicos dos átomos não hidrogenóides). b) Pt...Pt a 4,20 $\AA$ (cristais laranja) e c) Pt...Pt a 3,27 A (cristais vermelhos) [12]

praticamente não-emissiva, a forma vermelha é intensamente luminescente. E o mesmo ocorre para o complexo com terpy nas formas alaranjada e vermelha.

Gray et al. [12] realizaram investigações envolvendo a medida da estrutura cristalina da forma vermelha da $\left[\mathrm{Pt}(\right.$ bipy $\left.) \mathrm{Cl}_{2}\right]$ em diferentes temperaturas (298 e 20K). Eles verificaram assim que a distância interplanar Pt...Pt reduz de 3,40 § a $298 \mathrm{~K}$ para 3,37 Å a 20K. Ou seja, a cela cristalina sofre contração anisotrópica com a diminuição da temperatura, principalmente na direção do eixo $c$. Paralelamente, a banda de emissão no estado sólido sofre um deslocamento batocrômico de 613 nm a $298 \mathrm{~K}$ para $651 \mathrm{~nm}$ a $20 \mathrm{~K}$.

Segundo os autores, o estado emissivo desta espécie é ${ }^{3} \mathrm{MLCT}\left[\mathrm{d} \sigma^{*} \rightarrow \pi^{*}\right.$ (bipy)] onde o HOMO $\left(\mathrm{d} \sigma^{*}\right)$ deriva do orbital $\mathrm{d}_{z}{ }^{2}(\mathrm{Pt})$ e o LUMO $\left(\pi^{*}\right)$ é centrado na bipy. Por causa dessa configuração do estado excitado, a aproximação entre os centros metálicos promove um aumento no acoplamento eletrônico entre as unidades moleculares, já que o intervalo de energia $\mathrm{d} \sigma^{*}-\pi^{*}$ diminui. Essa variação por sua vez desloca a banda de emissão para regiões de maior comprimento de onda. 


\subsubsection{Sistemas Supramoleculares}

Os metais $d^{8}$ são materiais precursores bem conhecidos na preparação de uma grande variedade de espécies supramoleculares nanoscópicas de simetria, forma e geometria bem definidas [167]. Veja por exemplo a figura 1.21 onde são apresentados dois exemplos de quadrados moleculares de Pt(II) e Pd(II) obtidos a partir da coordenação com 4,4'-bipy (figura 1.21a) e da titulação do complexo de 1,1-bis(fosfino)ferroceno com 2,7-diazapireno [168, 169].

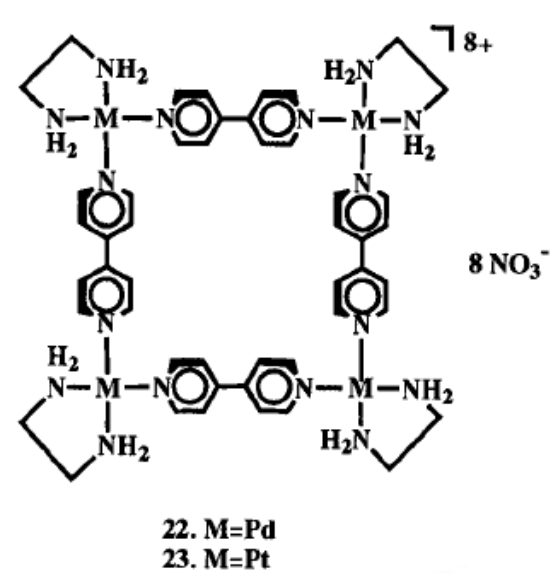

(a)

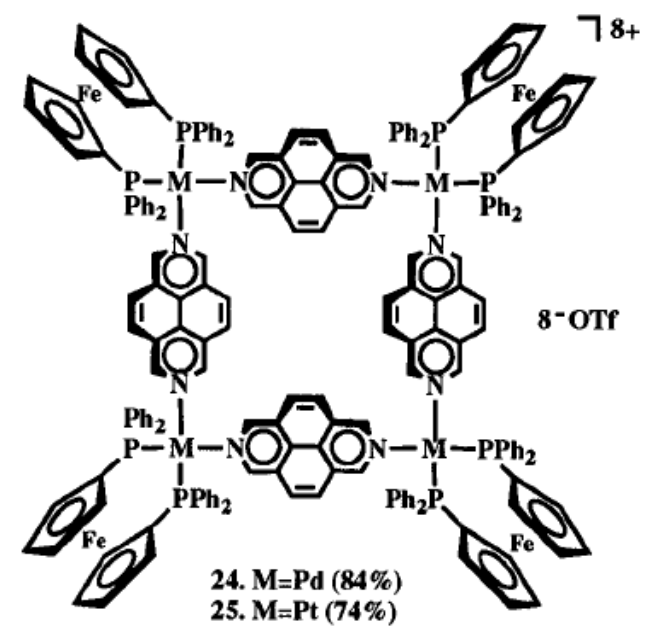

(b)

Figura 1.21: Exemplos de quadrados moleculares obtidos por auto-montagem de complexos diimínicos de $\mathrm{Pt}(\mathrm{II})$ e $\mathrm{Pd}(\mathrm{II})$.

Devido a carga elevada, essas espécies geralmente são solúveis em água e, de forma similar ao observado para complexos mononucleares de platina(II), essas redes de quadrados moleculares tendem a cristalizar na forma de pilhas moleculares, conforme ilustrado na figura 1.22 .

Por fim, pela combinação de complexos diimínicos com unidades organometálicas de platina(II), pode-se chegar a estruturas supramoleculares contendo até 12 centros metálicos, conforme apresentado na figura 1.23 [170]. Segundo Stang et al., a modelagem molecular indica que esse hexâmero supermolecular possui um diâmetro interno de $3 \mathrm{~nm}$, podendo encapsular por exemplo até 3 moléculas de fulereno. [167]. 

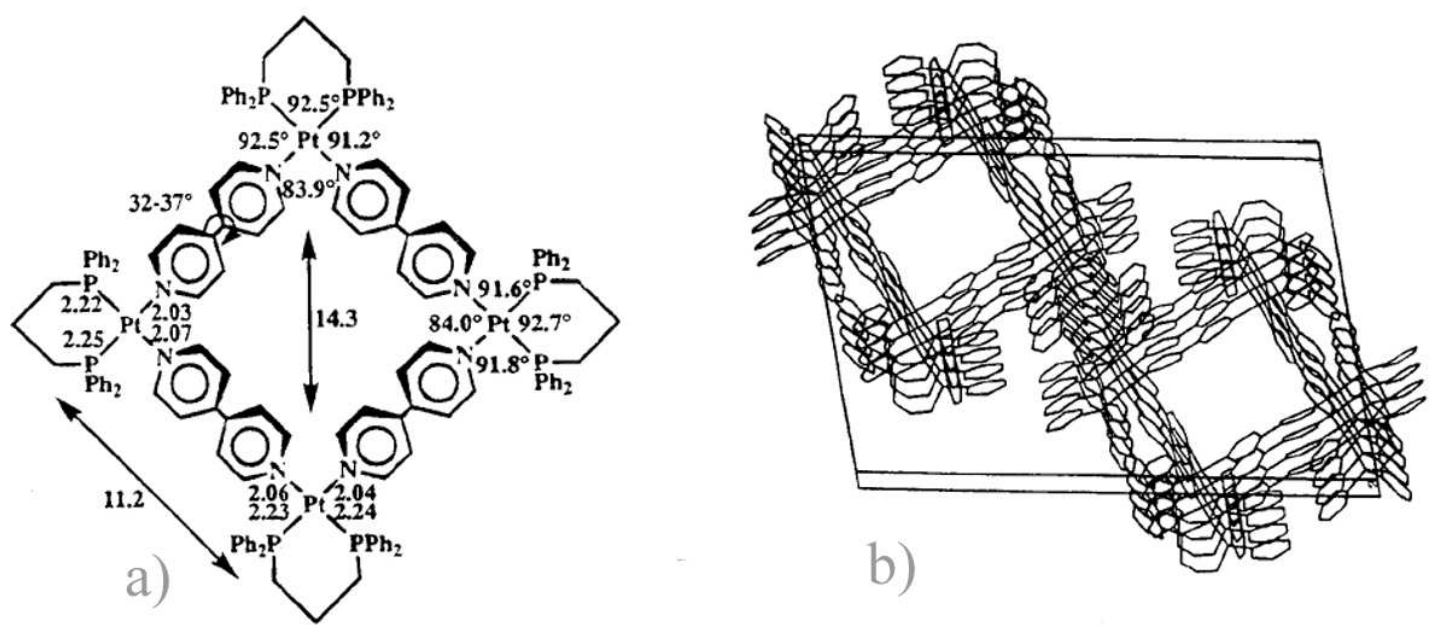

Figura 1.22: Complexos supermoleculares de platina(II)-polipiridinas. a) As setas e os números indicam as distâncias em A. b) Projeção do arranjo molecular na cela unitária.
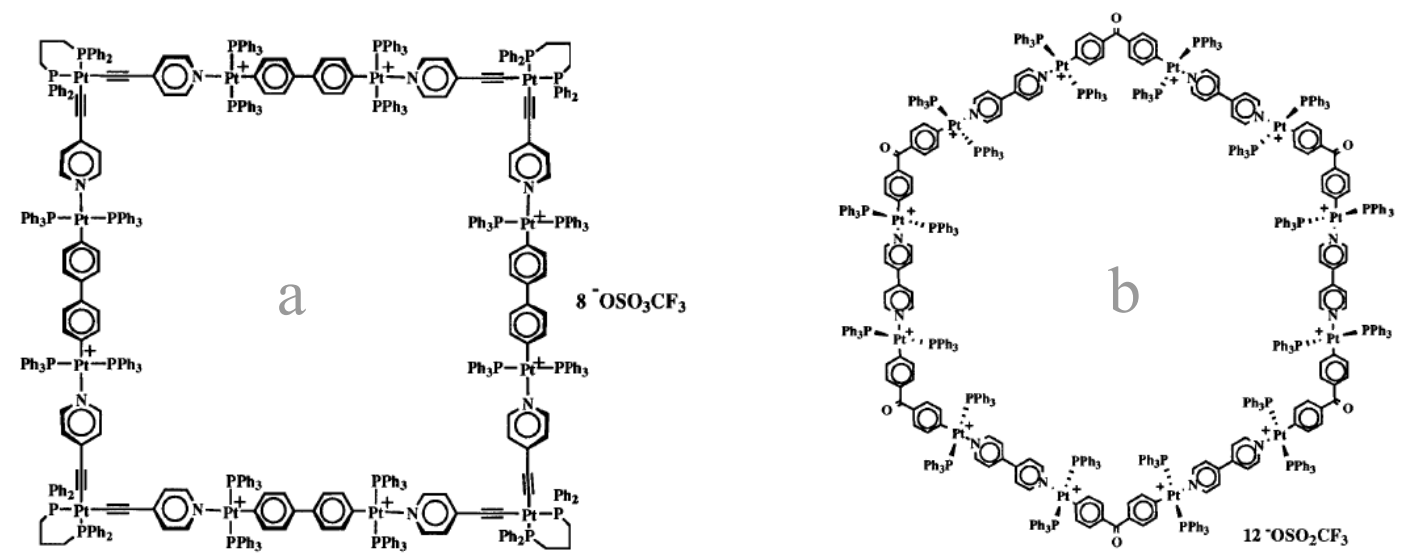

Figura 1.23: Estruturas supermoleculares contendo até 12 centros de platina

Em termos de aplicações, complexos poliimínicos de platina (II) já foram testados como sensibilizadores em células solares fotoeletroquímicas [171,172], na preparação de tríades moleculares tipo D-C-A com o propósito de construir-se dispositivos moleculares fotoquímicos para conversão de energia luminosa em energia química [56,163], na síntese de sensores químicos luminescentes (sistemas do tipo cromóforo-espaçador-receptor) capazes de reconhecer íons seletivamente [173] e na preparação de filmes LangmuirBlodget [174]. Isto sem mencionar os vastos estudos abordando atividade biológica [137-143]. 


\subsection{Complexos Porfirínicos de Platina}

\subsubsection{Arranjos Quadrado Moleculares}

Uma estratégia similar àquela usada para os complexos de platina(II)-diiminas, tem sido aplicada para a obtenção de espécies supramoleculares envolvendo piridilporfirinas coordenadas perifericamente a platina(II) e paládio(II). Assim, as estruturas publicadas na literatura até o momento reportam a preparação de quadrados planares de multiporfirinas auto-organizados por coordenação aos íons metálicos Pt(II) e Pd(II).

O primeiro trabalho envolvendo essa classe de compostos foi reportado por Lehn \& Drain [13] (figura 1.24). Segundo esses autores, essas espécies são interessantes do ponto de vista supramolecular, pois a preparação de novos arranjos aprimoram o controle dos processos de auto-montagem; os quais são realizados através de interações governadas por efeitos de reconhecimento molecular.

De acordo com esses autores, as espécies representadas na figura 1.24 são obtidas através da titulação de soluções diluídas das respectivas porfirinas com cis ou trans $\left[\mathrm{M}(\mathrm{PhCN})_{2} \mathrm{Cl}_{2}\right](\mathrm{M}=\mathrm{Pt}$ ou $\mathrm{Pd})$. A formação dos produtos é acompanhada por deslocamento batocrômico e alargamento da banda Soret da porfirina. Eles observaram ainda uma redução de $50 \%$ a $80 \%$ no coeficiente de absortividade molar desta banda e uma redução de $\approx 60 \%$ na fluorescência da porfirina, demonstrando um grau significativo de acoplamento eletrônico entre as porfirinas e os centros metálicos.

Trabalhos posteriores desenvolvidos por Drain et al. [115, 175-177] abordam a preparação de outros sistemas oligoméricos obtidos pela auto-montagem coordenativa de Pt(II) e Pd(II) a mesofenilpiridilporfirinas. Segundo os autores, espera-se que esses sistemas proporcionem um aumento do entendimento da comunicação fotônica entre cromóforos mediada por interações metal-ligante e que sirvam como um guia para a formação de canais ou receptores moleculares. Além disso, espera-se também que funcionem no desenvolvimento de materiais moleculares fotônicos aplicáveis em ótica não-linear. 


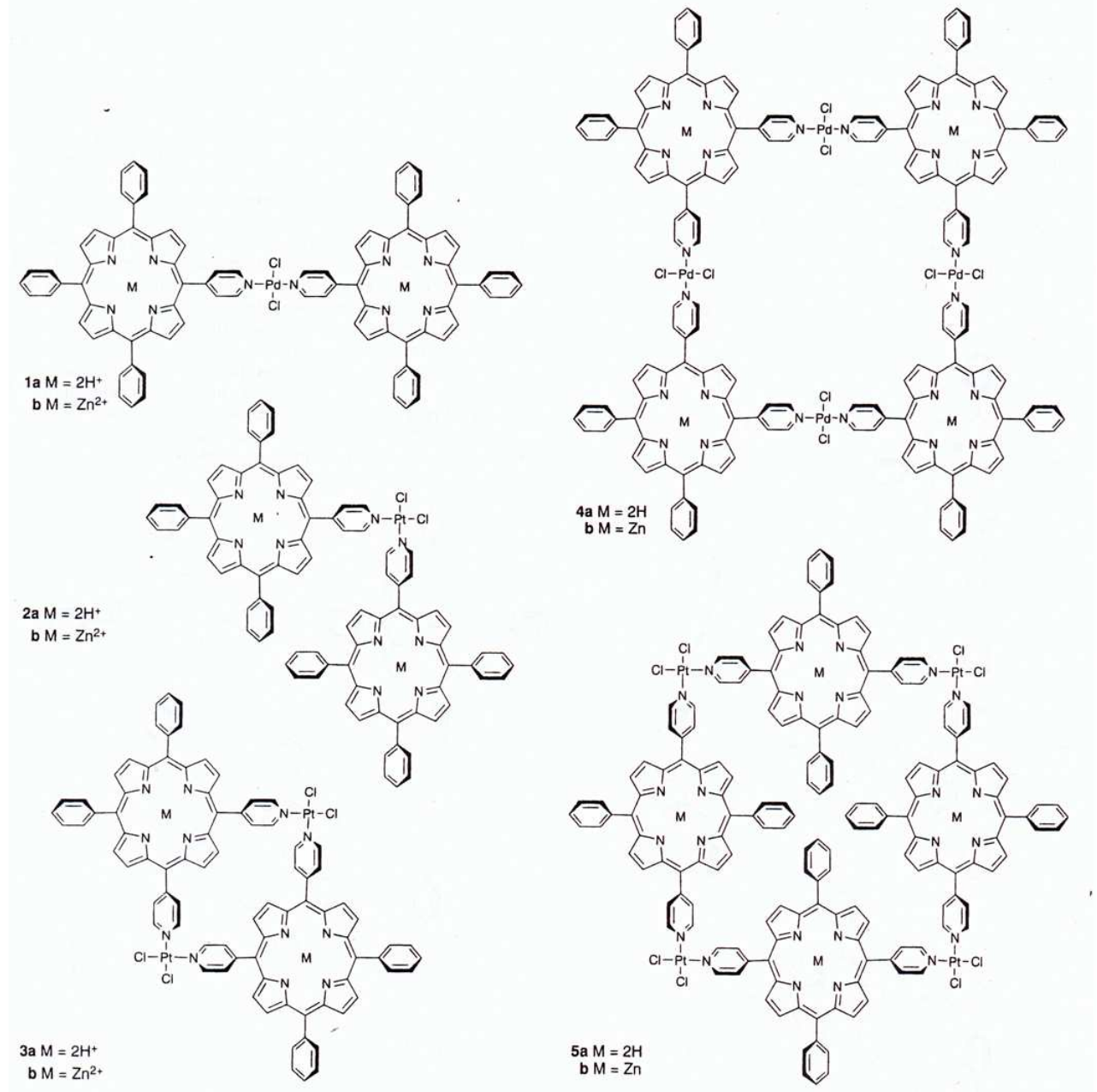

Figura 1.24: Dímeros e tetrâmeros de Pt(II) e Pd(II) coordenados a 10,15,20-trifenil5-piridil-porfirinato de zinco(II) e 15,20-difenil-5,10-dipiridil-porfirinato de zinco(II) [13]. 

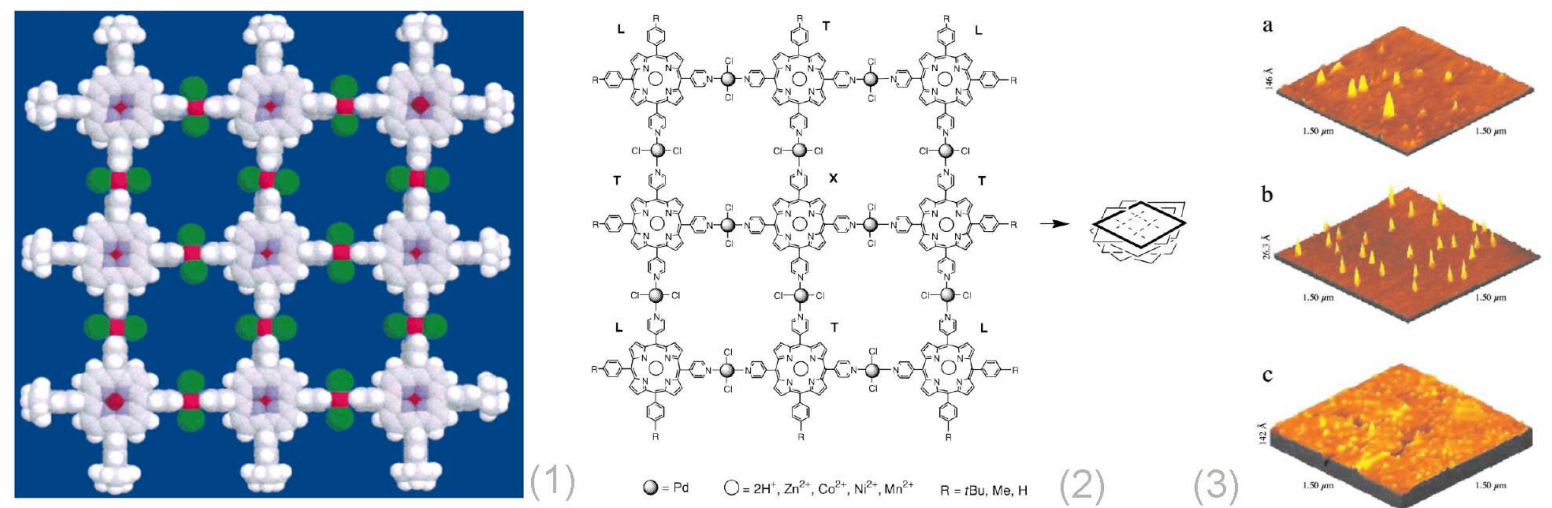

(3)

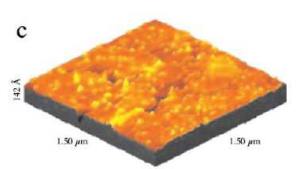

Figura 1.25: Nonâmero de multiporfirinas coordenadas a $\mathrm{Pd}(\mathrm{II})$. (1) Modelo teórico para $\mathrm{R}=\mathrm{CH}_{3}$, (2) Representação estrutural e (3) imagens AFM obtidas sobre vidro (3a), mica (3b) e ouro (3b).

Pela auto-organização de quatro cis-DPyDPhP (porfirinas do tipo L) e quatro 5fenil-10,15,20-tripiridilporfirina (porfirinas do tipo T) conectadas a 4-TPyP (porfirina do tipo $\mathrm{X}$ ) através de 12 grupos $\mathrm{PdCl}_{2}$ eles obtiveram nanoestruturas com largura de até $25 \mathrm{~nm}$, conforme ilustrado na figura 1.25.

Norteados por esses objetivos eles sintetizaram ainda sistemas planares e lineares, tipo fios moleculares, pela coordenação de grupos $\mathrm{PtCl}_{2}$ e $\mathrm{PdCl}_{2}$ a trifenilpiridil e difenildipiridilporfirinas, os quais estão reproduzidas na figura 1.26.

Com o intuito de avaliar a potencial aplicação desses nanofios moleculares como dispositivos fotônicos eles testaram a inserção dos mesmos em uma membrana lipídica de dupla camada, chegando a uma fotocorrente máxima de $85 \mathrm{nV}$ [176].

Um segundo grupo de sistemas supramoleculares análogos são relatados por Stang et al. $[178,179]$. Nesses trabalhos, é reportado a síntese de redes de duas a quatro piridilporfirinas coordenadas a complexos bifosfínicos de $\mathrm{Pd}(\mathrm{II})$ e $\mathrm{Pt}(\mathrm{II})$. O esquema genérico destas sínteses segue a mesma estratégia aplicada por Drain, empregando as piridilporfirnas como componentes lineares ou angulares para pré-determinar a simetria e a topologia do sistema. Observe que os complexos metálicos de Pt e Pd também atuam como conectores lineares (complexos trans), ou angulares (complexos cis) nestes sistemas. A figura 1.27 apresenta algumas estruturas de exemplo. 

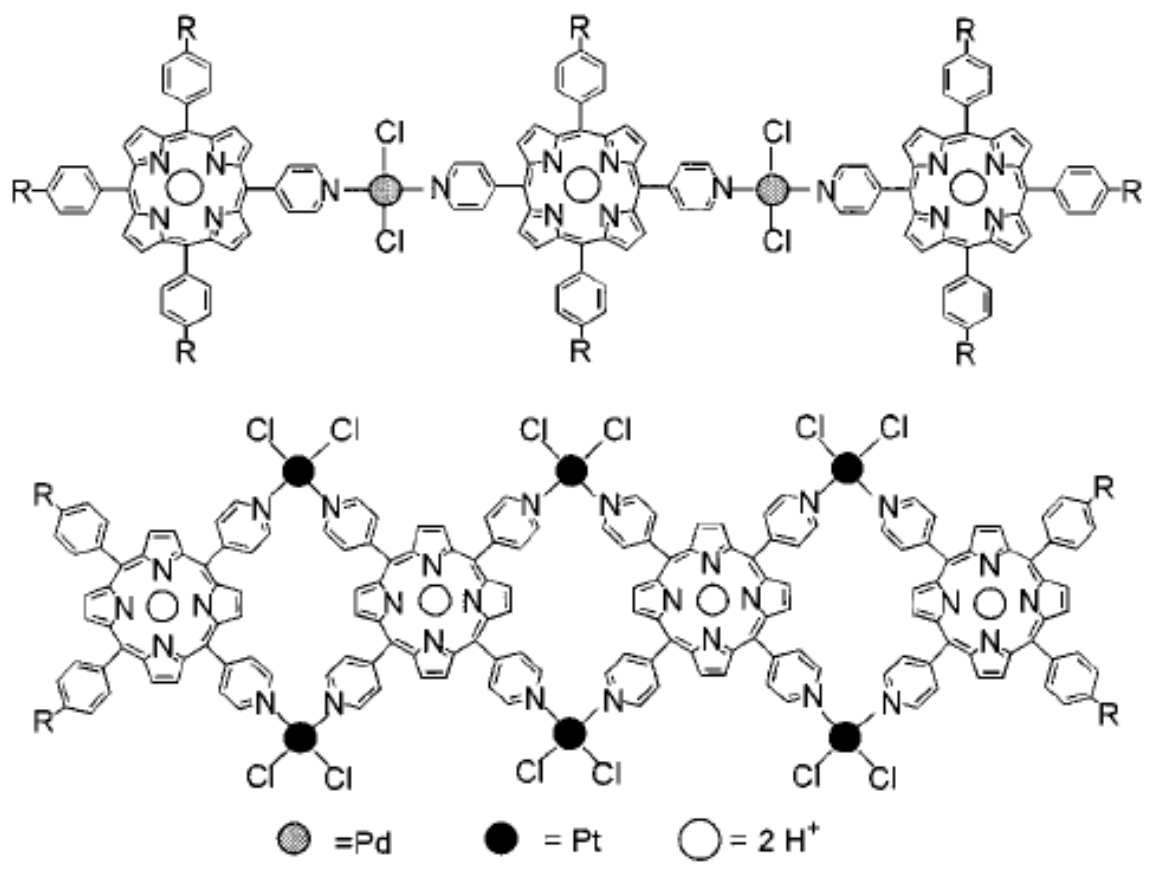

Figura 1.26: Fios moleculares de porfirinas coordenadas a cis- $\left[\mathrm{PtCl}_{2}\right]^{2+}$ e trans$\left[\mathrm{PdCl}_{2}\right]^{2+}$.

Em relação à preparação desses sistemas, enquanto que os trabalhos prévios de Drain reportam que a obtenção das espécies supramoleculares se dá através de titulação direta entre os reagentes, Stang descreve que as sínteses são realizadas sob agitação e aquecimento em $\mathrm{DCM}$ ou $\mathrm{CHCl}_{3}$ por várias horas.

Por fim, o trabalho de Woo et al. [180] relata a síntese e caracterização de mono- bise tetrakis-(piridiltriaril)porfirinas ligadas a esses dois metais $\mathrm{d}^{8}$. O complexo mostrado na figura 1.28 se destaca por apresentar uma estrutura pouco comum. Isto porque o impedimento estérico conferido por ligantes macrocíclicos organizados de tal forma ao redor do centro metálico tende a tornar essa geometria instável. Já na figura 1.29 temos a estrutura cristalina do dímero obtido com paládio, onde verifica-se que o metal possui geometria pseudo-quadrado planar. 

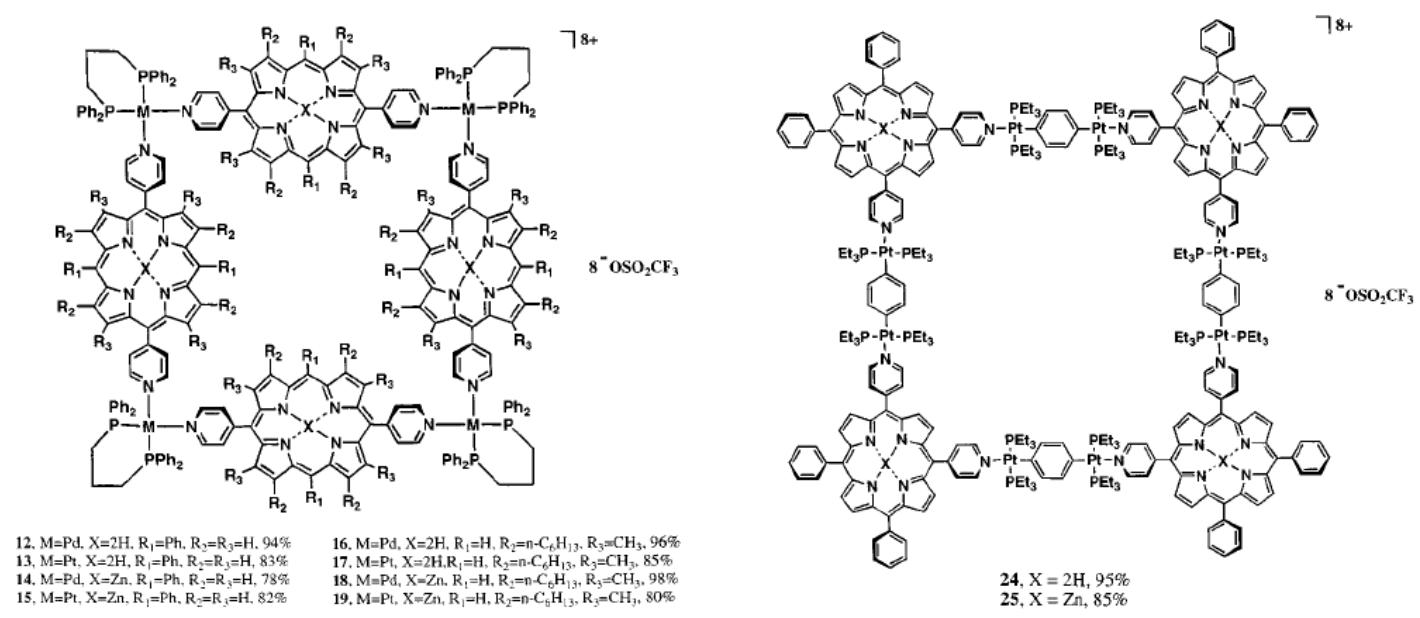

Figura 1.27: Quadrados moleculares de piridilporfirinas coordenadas a complexos bifosfínicos de $\mathrm{Pt}(\mathrm{II})$ e $\mathrm{Pd}(\mathrm{II})$.
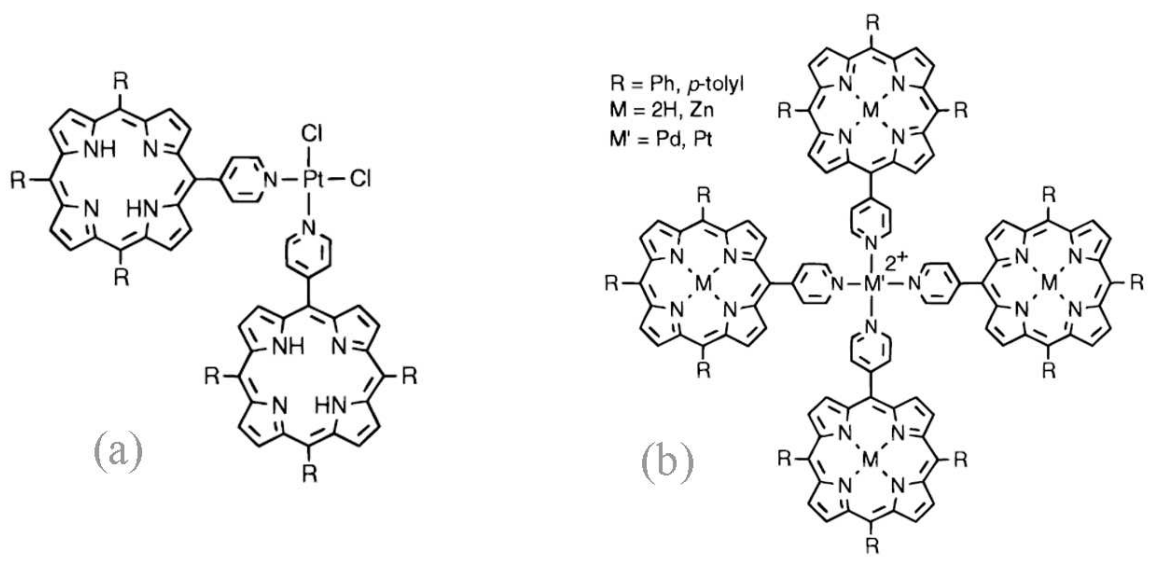

Figura 1.28: Representação estrutural dos complexos (a) cis- $\left\{\mathrm{Pt}\left[(\operatorname{pyPP}) \mathrm{H}_{2}\right]_{2} \mathrm{Cl}_{2}\right\}$ e (b) $\left\{\mathrm{M}\left[(\mathrm{pyP}) \mathrm{H}_{2}\right]_{4} X_{2}\right\}\left(\mathrm{M}=\mathrm{Pt}^{2+}\right.$ e $\mathrm{Pd}^{2+} ; \mathrm{X}=\mathrm{BF}_{4}^{-}$e OTf- $)$.

\subsubsection{Atividade Biológica}

De forma similar ao observado para complexos imínicos de platina(II), as porfirinas também interagem com DNA tanto por intercalação como por ligação externa [181$183]$.

Essa interação de porfirinas com DNA é especialmente forte para espécies catiônicas [84,182-184]. Complexos catiônicos supermoleculares como a porfirina tetrarutenada de zinco(II) (figura 1.13, pág. 21) exibem grupos ativos redox e fotoquimicamente, capazes de interagir via mecanismos de TE e TEl com esse biopolímero [77,84]. 


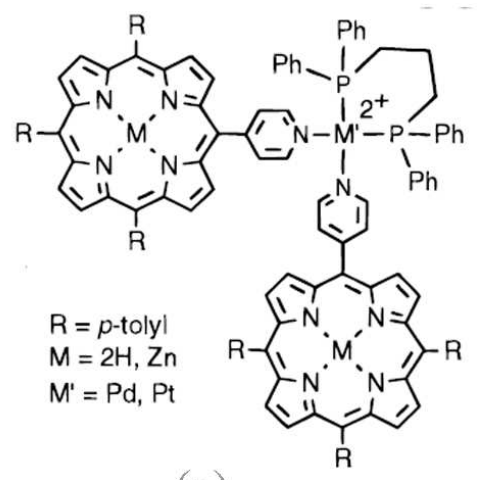

(a)

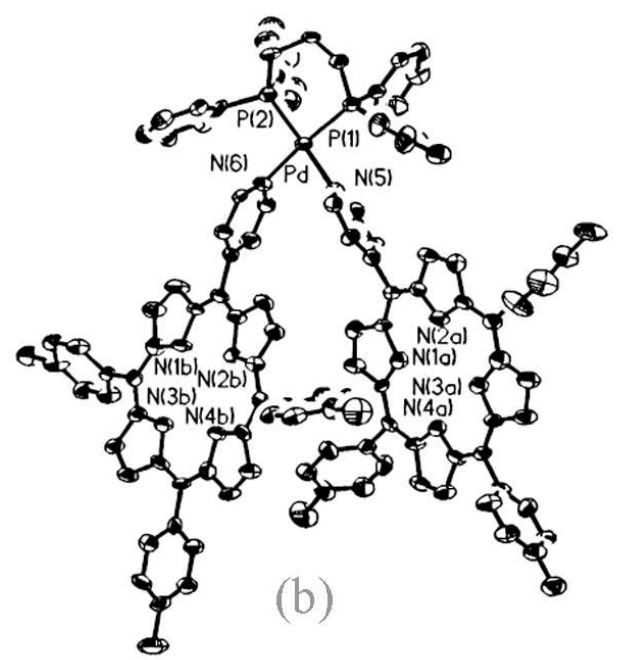

Figura 1.29: Estrutura cristalina/molecular para $\left.\left\{[\mathrm{Pd}(\mathrm{DPPP})]\left[(\text { pyTP }) \mathrm{H}_{2}\right)_{2}(\mathrm{OTf})_{2}\right]\right\}$ (nível de probabilidade de $50 \%$ para os elipsóides térmicos dos átomos não hidrogenóides).

Trabalhos reportados na literatura indicam que quando as porfirinas intercalam com DNA a interação se dá preferencialmente entre as seqüências GC. Já quando essa aproximação acontece numa seqüência rica em AT, ocorre modo de ligação externo [181]. Essas investigações relatam ainda que um fator determinante para a intercalação de porfirinas é a ausência de impedimento estérico nas posições axiais do anel, de modo que espécies base-livre ou coordenadas a $\mathrm{Cu}(\mathrm{II})$ e $\mathrm{Ni}(\mathrm{II})$ intercalam mais facilmente $[152,181]$.

Como as porfirinas são ativas em terapia fotodinâmica, PDT [185] $]^{3}$ e os complexos de platina tem atividade antitumoral, espera-se que a conjugação destas unidades num único complexo resulte num efeito sinérgico ou aditivo dessas duas propriedades, levando a compostos com atividade citostática e fotodinâmica [145, 188-191].

Além do mais, uma variedade de estratégias e sistemas tem sido investigados no sentido de alcançar uma distribuição seletiva dos fármacos no tecido tumoral para diminuir os efeitos colaterais da cis-platina e carboplatina. Nesse sentido, sabe-se que as porfirinas são seletivas na interação com biomoléculas [192,193]. Sugere-se que elas

\footnotetext{
${ }^{3} \mathrm{~A}$ PDT é um tratamento médico baseado no uso de um sensibilizador para promover danos fotoinduzidos em moléculas biológicas incluindo lipídios, proteínas e ácidos nucléicos. Ela pode ser usada para erradicar tumores localizados ou como paliativo em doenças mais avançadas onde formou-se metastase [185-187]
} 
acumulem preferencialmente em lipoproteínas de baixa densidade, uma vez que células tumorais apresentam elevados níveis de LDL [194].

Devido a esses aspectos, complexos porfirínicos de platina(II) podem dar acesso a modos de interação diferentes com DNA; aumentar a seletividade da porção antitumoral de $\mathrm{Pt}(\mathrm{II})$ e ter a atividade biológica realçada na presença de luz.

A figura 1.30 traz exemplos de alguns complexos substituídos de porfirinas com platina estudados frente a esses objetivos $[145,189]$.
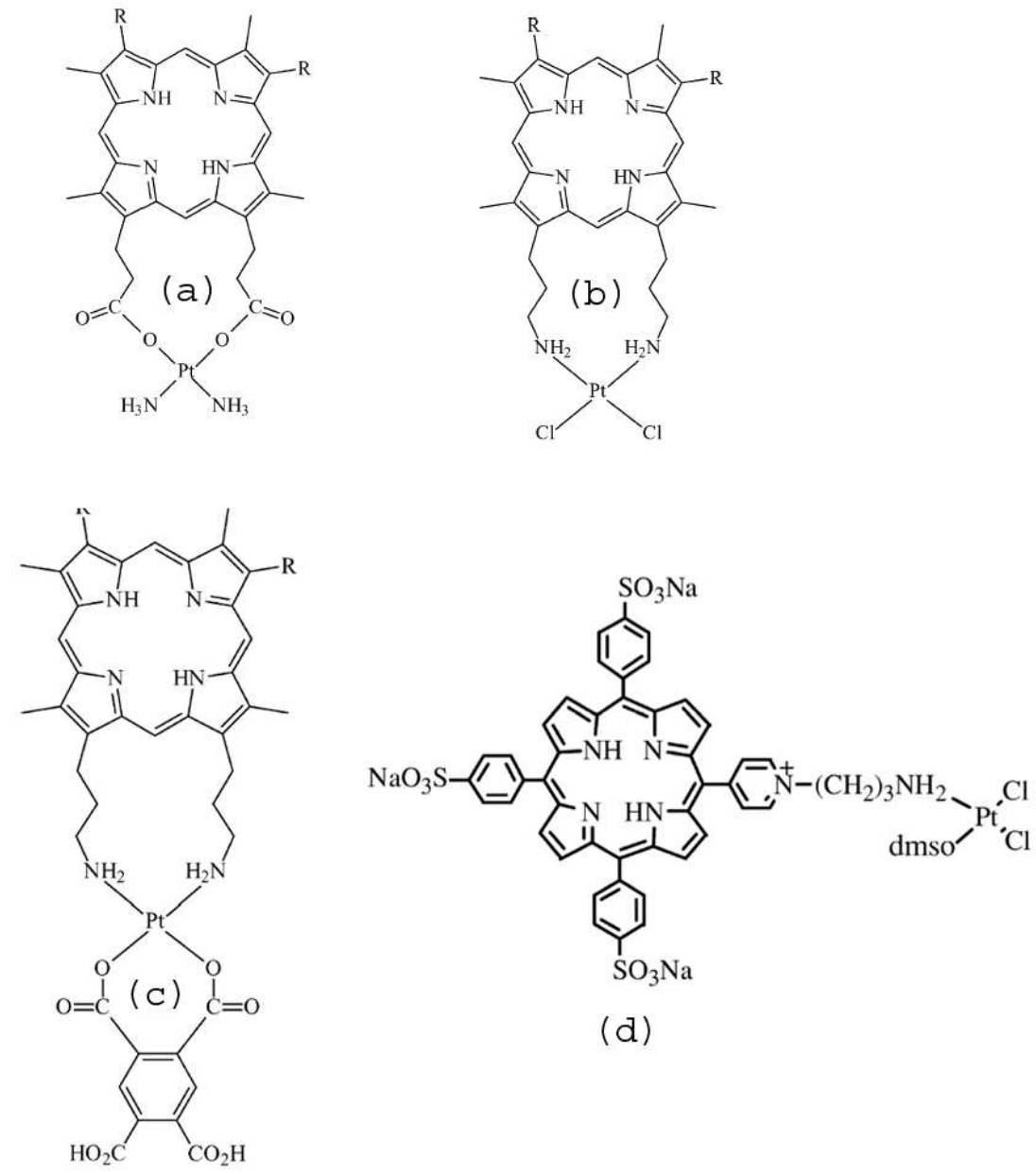

(d)

Figura 1.30: Complexos de platina(II)-porfirina com potencial atividade biológica.

Song et al. [188] investigaram uma série catiônica de complexos solúveis em água de meso-mono(fenil)-tris(N-metilpiridinio)porfirina coordenados a platinato complexos diimínicos e dicarboxílicos. Essas espécies foram testadas in vivo e in vitro em relação 
a sua atividade antitumoral contra linhas de células de leucemia L1210. Segundo os autores, algumas espécies desses sistemas apresentaram atividade antitumoral in vitro superior a cisplatina. Trabalhos adicionais envolvendo o estudo de atividade biológica e interação com biomoléculas de complexos porfirínicos de platina podem ser encontrados nos trabalhos de Brunner et. al. [195-197].

\subsection{Objetivos}

Nos dedicamos neste projeto ao preparo, caracterização e estudo de propriedades de novos complexos supermoleculares de tetrapiridilporfirinas tetracoordenadas com complexos diimínicos de platina(II). Investigou-se desse modo a síntese de novas supermoléculas a partir das porfirinas 3-TPyP e 4-TPyP associadas aos grupos coordenantes ilustrados na figura 1.31 .

Em relação aos estudos conduzidos, buscou-se a caracterização dos novos sistemas por análise elementar, análise térmica, espectroscopia UV/VIS, FT-IR, espectrometria de massa por spray de elétrons e RMN de ${ }^{1} \mathrm{H}$ e ${ }^{195} \mathrm{Pt}$. Em relação as propriedades e aplicações das supermoléculas, procurou-se avaliar o perfil eletroquímico por voltametria cíclica e espectroeletroquímica, a preparação de arranjos supramoleculares por associação eletrostática, a investigação do perfil de interação com DNA por SPR e a preparação de filmes moleculares caracterizados por SPM. Procurou-se por fim correlacionar os dados experimentais com cálculos de química teórica. A escolha por duas estruturas isoméricas foi feita com o objetivo de avaliar-se o efeito da geometria sobre as propriedades das supermoléculas e dos respectivos sistemas supramoleculares.

Quanto a química supramolecular dos sistemas de platina(II)-porfirina previmente reportados na literatura, propõe-se aqui uma abordagem diferente. Ao invés de prepararse estruturas supramoleculares por meio da síntese direta entre os centros metálicos e as porfirinas, realizou-se primeiramente a síntese das supermoléculas para após empregálas como unidades precursoras na preparação de diferentes arranjos supramoleculares. 

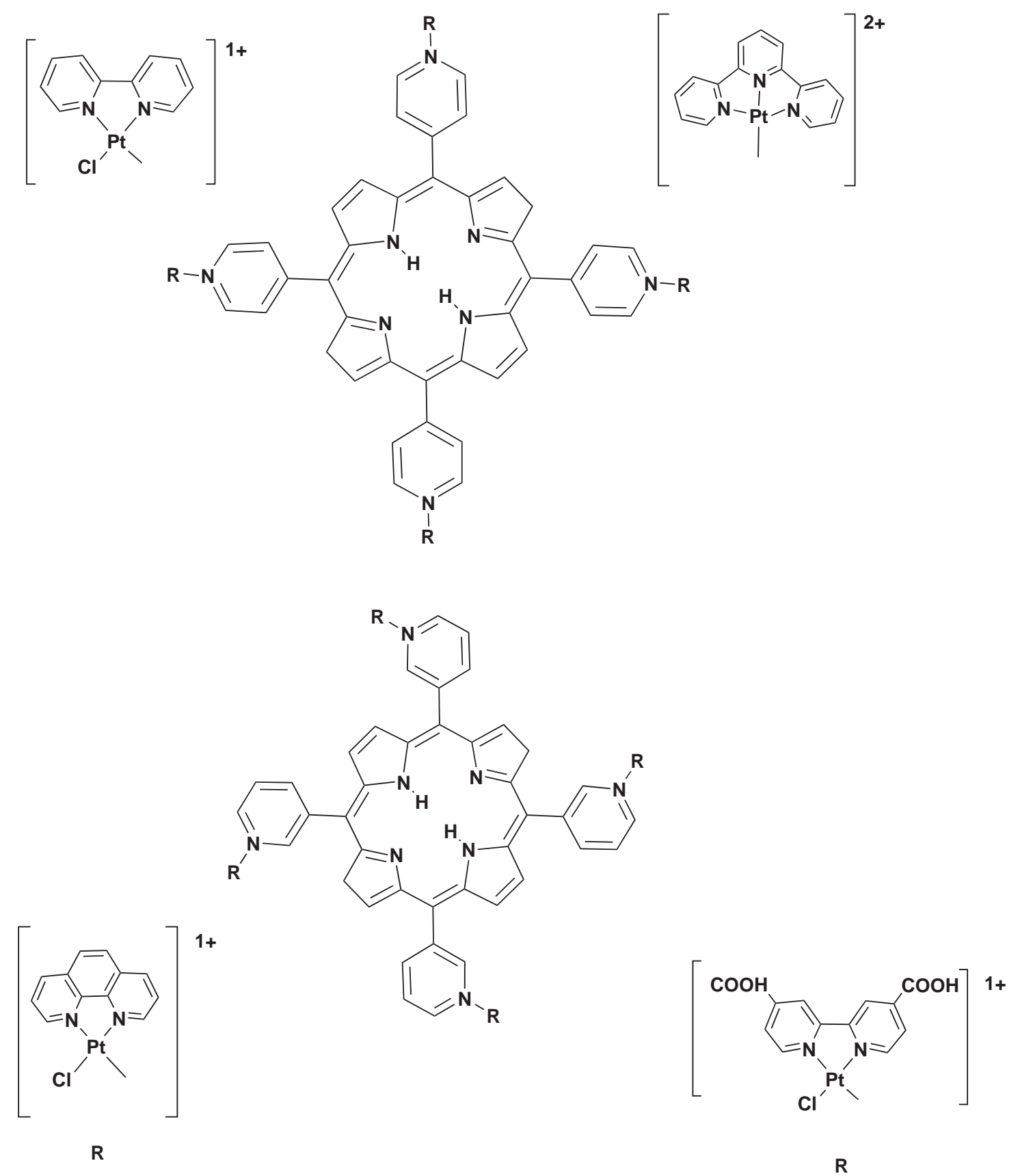

Figura 1.31: Fragmentos precursores para a síntese de novas supermoléculas de platina(II)-tetrapiridilporfirinas. 
Uma das principais vantagens dessa estratégia é que podemos obter diversos arranjos com um maior controle da composição e da estrutura final. Em alguns sistemas quadrado planares como o nonâmero de paládio(II) reportado por Drain et al. [175, 177], outras possibilidades de auto-organização da estrutura são pouco ou nada discutidas. Neste caso por exemplo, além da coordenação periférica com $\mathrm{Pd}(\mathrm{II})$, os grupos piridínicos da porfirina podem coordenar-se axialmente ao íon $\mathrm{Zn}(\mathrm{II})$, originando estruturas substancialmente diferentes daquela proposta.

Temos um interesse particular em estudar os complexos polipiridínicos de platina(II) pela capacidade de interagirem com biomoléculas, onde vislumbramos as áreas de sensores de materiais híbridos inorgânico-biológicos e terapia fotodinâmica, pela geometria planar que os sistemas $\mathrm{d}^{8}$ apresentam, devendo favorecer a formação de filmes finos nanoestruturados altamente homogêneos, e pelas propriedades espectroscópicas e fotofísicas desses complexos, podendo dar origem a materiais interessantes em dispositivos fotônicos. Além do mais, complexos contendo ligantes bipiridínicos com substituintes carboxilatos nas posições 4,4' têm recebido especial atenção por adsorverem quimicamente sobre $\mathrm{TiO} 2$ nanocristalino, de forma que uma nova espécie supramolecular de platina(II)-dicarboxibipiridina pode vir a atuar como corante fotosensibilizador em células solares de Gratzel [171,172,198].

Neste trabalho são apresentados os resultados concernentes a síntese, caracterização, preparação de arranjos supramoleculares e estudo de propriedades das espécies [4-TPyPPt(bipy) $\left.\mathrm{Cl}_{4}\right] \mathrm{Cl}_{4}$ e [3-TPyPPt(bipy) $\left.\mathrm{Cl}_{4}\right] \mathrm{Cl}_{4}$. Resultados preliminares para outras supermoléculas de tetrapiridilporfirinas associadas aos complexos $[\mathrm{Pt}(\mathrm{tpy}) \mathrm{Cl}] \mathrm{Cl}$ e $\left[\mathrm{Pt}(\mathrm{dcbpy}) \mathrm{Cl}_{2}\right]$ são brevemente reportados nos apêndices. 


\section{Capítulo 2}

\section{Parte Experimental}

\subsection{Sínteses}

Os solventes e reagentes empregados eram todos de grau analítico e foram usados como recebidos, exceto quando especificado. A base-livre meso-4-tetrapiridilporfirina, 4-TPyP, e a ftalocianinatetrassulfonada de cobre(II), CuPcTS, foram adquiridas da Aldrich. A síntese do complexo $\left[\mathrm{Pt}\left(\right.\right.$ bipy $\left.\mathrm{Cl}_{2}\right]$ e da porfirina base-livre meso-3-tetrapiridilporfirina, 3-TPyP, foi realizada segundo metodologia da literatura [199-201] e estão descritas abaixo. A água empregada nas lavagens e preparação de soluções foi destilada e purificada através de um aparato Millipore Milli-Q.

\subsubsection{Síntese do complexo dicloro-2,2'-bipiridina-platina(II)}

$200 \mathrm{mg}$ de $\mathrm{K}_{2} \mathrm{PtCl}_{4}(0,48 \mathrm{mmol})$ são dissolvidos em $25 \mathrm{~mL}$ de água. Sobre esta solução adiciona-se $77 \mathrm{mg}$ de 2,2’-bipiridina (0,49 mmol) previamente dissolvida em $1 \mathrm{~mL}$ de $\mathrm{HCl} 2 \mathrm{~mol} \cdot \mathrm{dm}^{-3}$. A solução é aquecida sob agitação até próximo do ponto de ebulição d'água e mantida assim até a formação de um precipitado amarelo, o qual é filtrado, lavado com água e etanol e seco sob vácuo. Rendimento: 95\%. Análise elementar: $\mathrm{PtC}_{10} \mathrm{H}_{8} \mathrm{~N}_{2} \mathrm{Cl}_{2}$ (Exp.) Calc.: \%C (28,5) 28,4; \% $\mathrm{H}(1,7)$ 1,9; \% $\mathrm{N}(6,3) 6,6$. RMN ${ }^{1} \mathrm{H}: \mathrm{H} 1 \mathrm{~d}=8,5 \mathrm{ppm}(\mathrm{d}), \mathrm{H} 2 \mathrm{~d}=8,4 \mathrm{ppm}(\mathrm{t}), \mathrm{H} 2^{\prime} \mathrm{d}=7,8 \mathrm{ppm}(\mathrm{t})$ e $\mathrm{H} 3 \mathrm{~d}=9,4$ 


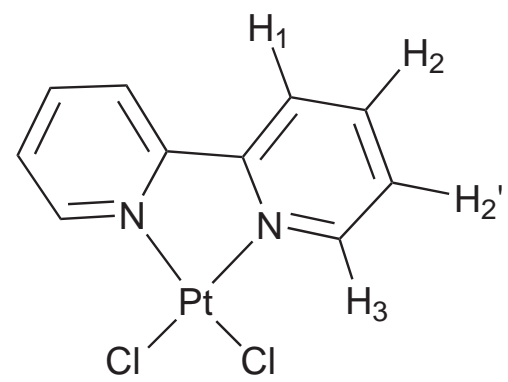

Figura 2.1: Estrutura do complexo $\left[\mathrm{Pt}(\right.$ bipy $\left.) \mathrm{Cl}_{2}\right]$ com indicação das atribuições para ${ }^{1} \mathrm{H}$ RMN

ppm (d) (figura 2.1).

\subsubsection{Síntese da supermolécula tetracloreto meso-tetra(4-piridil)- porfirina- tetrakis-(2,2`-bipiridina-cloro-platina(II)}

$62 \mathrm{mg}$ de 4- $\mathrm{H}_{2} \mathrm{TPyP}(0,1 \mathrm{mmol})$ são dissolvidos em $10 \mathrm{~mL}$ de 2,2,2-trifluoretanol (TFE) e sobre esta solução adiciona-se $170 \mathrm{mg}$ de $\mathrm{Pt}($ bipy $) \mathrm{Cl}_{2}(0,41 \mathrm{mmol})$. Esta mistura é aquecida a $50-55^{\circ} \mathrm{C}$ e mantida nesta temperatura sob agitação por 24 horas. Logo após desliga-se o aquecimento e deixa-se reagir por mais 24 horas. O progresso da reação é acompanhado pelos espectros UV-VIS e pelo consumo do precipitado de $\mathrm{Pt}$ (bipy) $\mathrm{Cl}_{2}$, formando uma solução homogênea vermelho-violeta intenso. Ao final o solvente é rota-evaporado sob baixa pressão e o produto obtido é lavado com água e acetonitrila, filtrado e seco sob vácuo. O complexo tem cor azul marinho e apresenta brilho. Rendimento: $72 \%$. Análise elementar: $\left[\left(\mathrm{C}_{40} \mathrm{H}_{26} \mathrm{~N}_{8}\right)\left(\mathrm{PtC}_{10} \mathrm{H}_{8} \mathrm{~N}_{2} \mathrm{Cl}\right)_{4}\right] \mathrm{Cl}_{4} \cdot 8 \mathrm{H}_{2} \mathrm{O}$ (Exp.) Calc.: $\% \mathrm{C}=(38,2) 39,2 ; \% \mathrm{H}(2.8) 3,0 ; \% \mathrm{~N}(8,6) ; 9,1$ (figura 2.2).

\subsubsection{Síntese da supermolécula tetracloreto meso-tetra(3-piridil)- porfirina- tetrakis- $\left(2,2^{\circ}\right.$-bipiridina-cloro-platina(II)}

$62 \mathrm{mg}$ de $3-\mathrm{H}_{2} \mathrm{TPyP}(0,1 \mathrm{mmol})$ são dissolvidos em $10 \mathrm{~mL}$ de TFE e sobre esta solução adiciona-se $170 \mathrm{mg}$ de $\mathrm{Pt}($ bipy $) \mathrm{Cl}_{2}(0,41 \mathrm{mmol})$. Esta mistura é aquecida a $50-55^{\circ} \mathrm{C}$ e mantida nesta temperatura sob agitação por 24 horas. Logo após desliga-se 


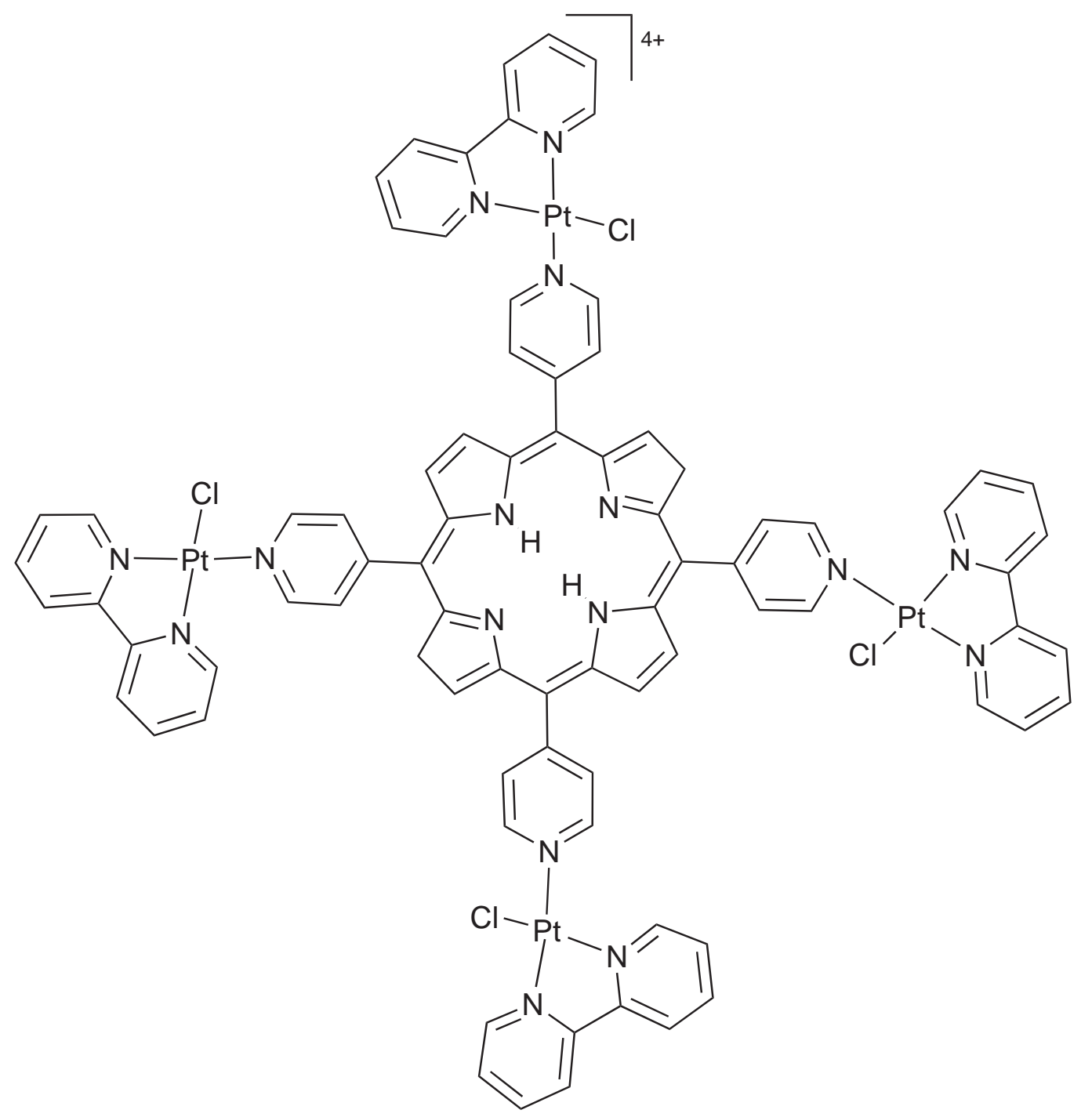

Figura 2.2: Estrutura da nova supermolécula 4-TPtTPyP. 


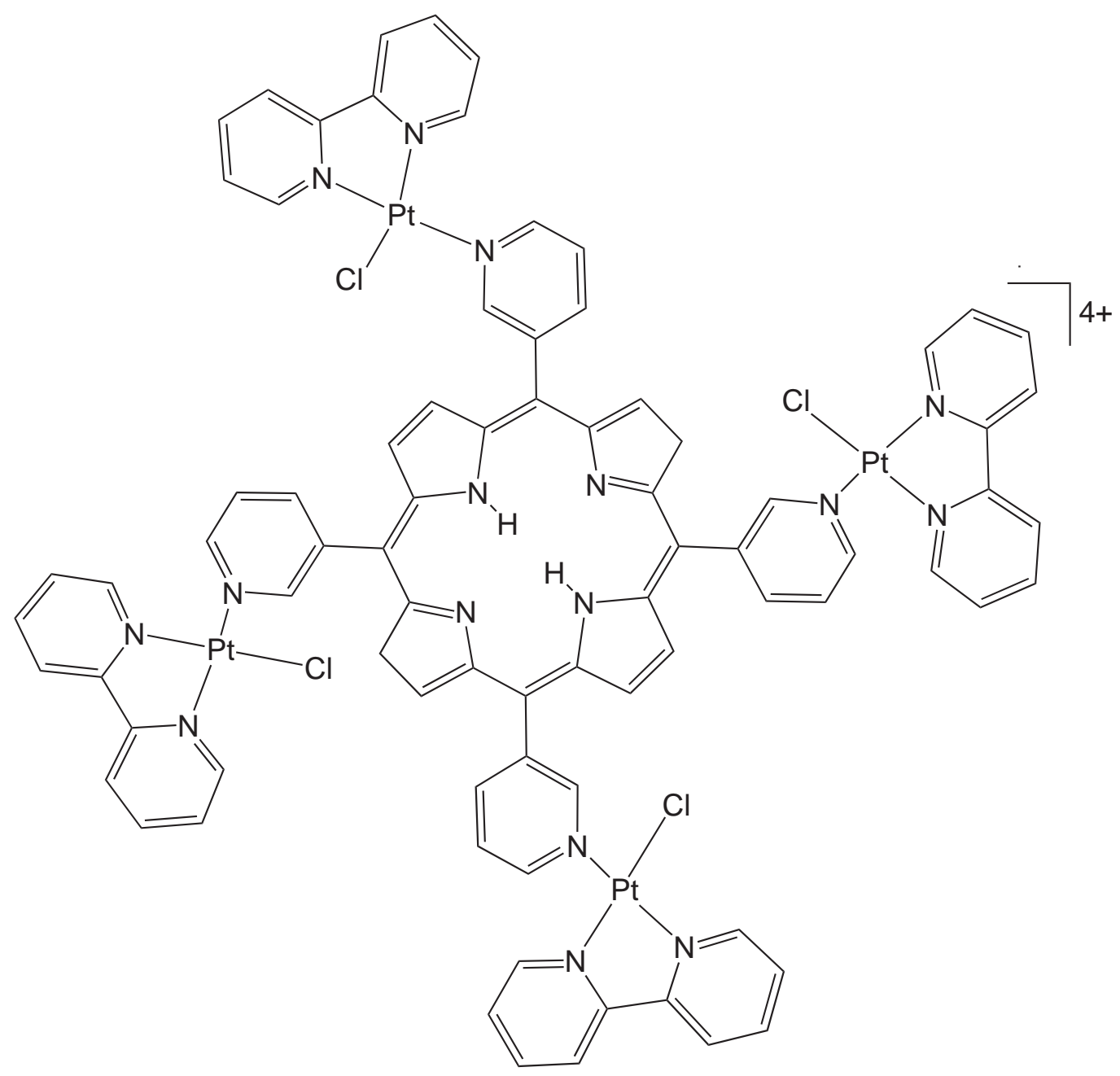

Figura 2.3: Estrutura da nova supermolécula 3-TPtTPyP

o aquecimento e deixa-se reagir por mais 24 horas. O progresso da reação é acompanhado pelos espectros UV-VIS e pelo desaparecimento do precipitado de $\mathrm{Pt}\left(\right.$ bipy) $\mathrm{Cl}_{2}$, formando uma solução homogênea vermelho-violeta intenso. Ao final o solvente é rotaevaporado sob baixa pressão e o produto obtido é lavado com água e acetonitrila, filtrado e seco sob vácuo. O complexo tem cor azul marinho e apresenta brilho. Rendimento: 52\%. Análise elementar: $\left[\left(\mathrm{C}_{40} \mathrm{H}_{26} \mathrm{~N}_{8}\right)\left(\mathrm{PtC}_{10} \mathrm{H}_{8} \mathrm{~N}_{2} \mathrm{Cl}\right)_{4}\right] \mathrm{Cl}_{4 \cdot 8} \mathrm{H}_{2} \mathrm{O}$ (Exp.) Calc.: $\% \mathrm{C}=(41,2) 39,2 ; \% \mathrm{H}(3,0) 3,0 ; \% \mathrm{~N}(9,4) ; 9,1$ (figura 2.3$)$.

A preparação das espécies metaladas com zinco(II) foi realizada em pequena escala pela titulação de soluções de 3-TPtTPyP e 4-TPtTPyP 3,5 x $10^{-6} \mathrm{~mol} \cdot \mathrm{dm}^{-3} \mathrm{em} \mathrm{MeOH}$ com acetato de zinco(II) $3,5 \times 10^{-3} \mathrm{~mol} \cdot \mathrm{dm}^{-3}$, também em MeOH. 


\subsection{Métodos}

\subsubsection{Titulações espectrofotométricas dos pares iônicos}

As titulações foram realizadas a temperatura ambiente e a cela de vidro foi previamente lavada com ácido clorídrico concentrado e água desionizada. Devido a baixa solubilidade das supermoléculas em água, as soluções foram preparadas numa mistura $\mathrm{H}_{2} \mathrm{O} / \mathrm{TFE}$ 8:2. As titulações foram conduzidas pela adição de alíquotas de $10 \mu \mathrm{L}$ de soluções $10^{-4} \mathrm{~mol} \cdot \mathrm{dm}^{-3}$ das respectivas supermoléculas 4-TPtTPyP e 3-TPtTPyP sobre $3 \mathrm{~mL}$ de uma solução $10^{-6} \mathrm{~mol} \cdot \mathrm{dm}^{-3}$ da CuPcTS. Os volumes foram adicionados através de micropipetas e apenas inverteu-se a relação das concentrações quando da titulação das supermoléculas com a CuPcTS.

Os dados obtidos pela titulação foram tratados através do método de Job [202, 203]. Os fatores de diluição foram considerados na construção dos diagramas e filmes homogêneos dos complexos associados por pareamento iônico foram obtidos sobre vidro e mica pela lenta evaporação de soluções $10^{-4}$ mol.dm ${ }^{-3}$ em $\mathrm{H}_{2} \mathrm{O} / \mathrm{TFE}$ 8:2.

\subsubsection{Estudos de interação com DNA}

A solução de Calf Thymus-DNA (CT-DNA) foi preparada em tampão tris-HCl, $\mathrm{pH}=7.4$, contendo $10 \%$ de TFE e $50 \mathrm{mM}$ de NaCl. A concentração de DNA, expressa em pares de bases nucleicas, foi determinada pela absortividade molar da banda a $260 \mathrm{~nm}\left(\epsilon=6.600 \mathrm{~mol}^{-1} \mathrm{~cm}^{-1}\right)$. As soluções das supermoléculas foram preparadas nas mesmas condições.

As titulações foram conduzidas em temperatura ambiente pela adição de pequenas alíquotas da solução de DNA sobre a solução das supermoléculas, obedecendo uma diferença de concentração de pelo menos 1 ordem de grandeza, para minimizar o efeito da diluição. 


\subsubsection{Modelagem molecular}

A otimização de geometria foi realizada através dos campos de força MM+ e MM2 modificado [204,205], empregando o programa HYPERCHEM [206]. Um gradiente de $10^{-3} \mathrm{Kcal} \cdot \mathrm{mol}^{-1} \cdot \AA^{-1}$ foi usado como critério de convergência num método de gradiente conjugado. Os orbitais moleculares foram calculados por DFT utilizando o conjunto de bases ECP LANL2DZ para resolver as equações de Kohn-Sham. Neste último caso, a metodologia empregou a correção por gradiente, utilizando o híbrido B3LYP. Empregou-se neste caso o software GAMESS (R4) [207].

\subsection{Instrumentos}

As medidas de análise elementar e RMN foram realizadas na central analítica do Instituto de Química da USP. As medidas de ESI-MS foram realizadas no Laboratório Thomson de Espectrometria de Massa no IQ da Unicamp. As medidas de análise térmica foram realizadas em equipamento disponível no Departamento de Química Fundamental do IQ/USP. Todas as demais medidas foram realizadas em equipamentos disponíveis na infraestrutura do LQSN.

\subsubsection{Análise térmica}

As análises termogravimétricas foram realizadas em uma termobalança Shimadzu modelo TGA 50 na faixa de $20-900^{\circ} \mathrm{C}$ com taxa de aquecimento de $10^{\circ} \mathrm{C} . \mathrm{min}^{-1}$ sob atmosfera de nitrogênio com fluxo de $50 \mathrm{~cm}^{3} \cdot \mathrm{min}^{-1}$. Empregou-se nas medidas cadinho de platina contendo de 4 a $6 \mathrm{mg}$ de amostra. Para a análise do complexo [Pt(bipy) $\mathrm{Cl}_{2}$ ] empregou-se um tempo de espera (hold time) de 20 minutos no final da rampa de aquecimento. 


\subsubsection{Espectrometria de massa com ionização por spray de elé- trons}

Os espectros de massa foram coletados no modo íon positivo (faixa m/z de 50-3000) num espectrômetro modelo Q-ToF (Waters Micromass, UK) configurado com quadrupolo (Qq) e alta resolução (7000) do tempo-de-vôo ortogonal (o-TOF). A introdução da amostra foi realizada através de uma bomba de seringa (Harvard Apparatus, Pump 11) calibrada para $10 \mu \mathrm{L} /$ min., bombeada através de um capilar de sílica fundida. Todas as amostras foram dissolvidas em metanol puro com faixas de concentração variando de $10^{-6}$ a $10^{-7} \mathrm{~mol} \cdot \mathrm{dm}^{-3}$. A medida do espectro foi realizada aplicando-se uma voltagem capilar ESI de 3kV e uma voltagem de cone de 10V. Essa aceleração relativamente baixa da voltagem de cone foi usada para minizar a dissociação induzida por colisão (CID). Os padrões isotópicos foram calculados empregando-se o programa MassLynx.

\subsubsection{Espectroscopia eletrônica}

Os espectros UV-VIS foram obtidos num espectrofotômetro Hewlett-Packart 8453A com rede de diodo.

\subsubsection{Espectroscopia vibracional}

Os espectros de infravermelho foram obtidos num espectrômetro Shimadzu modelo FTIR-8300 em pastilhas de KBr.

\subsubsection{Eletroquímica e espectroeletroquímica}

Os voltamogramas cíclicos foram medidos num potenciostato/galvanostato Autolab modelo pgstat30, empregando-se um arranjo convencional de cela com três eletrodos, o qual consiste de um eletrodo de trabalho de platina, um eletrodo auxiliar de fio de platina em espiral e um eletrodo de referência de $\mathrm{Ag} / \mathrm{AgNO}_{3}\left(0,010\right.$ mol.dm ${ }^{-3}$ em acetonitrila). 
Os experimentos de espectroeletroquímica foram realizados em uma cela de fina camada $[62,73]$ constituida de um mini-grid de ouro como eletrodo de trabalho, um eletrodo auxiliar de fio de platina e um eletrodo de referência de $\mathrm{Ag} / \mathrm{AgNO}_{3}(0,010$ $\mathrm{mol} \cdot \mathrm{dm}^{-3}$ em acetonitrila). Os potenciais foram aplicados através de um potenciostato/galvanostato EG\&G modelo 173.

Para os estudos de voltametria cíclica as medidas foram realizadas empregando-se soluções $5 \times 10^{-4} \mathrm{~mol} \cdot \mathrm{dm}^{-3}$ das supermoléculas 4-TPtTPyP e 3-TPtTPyP em DMF, contendo $\mathrm{TEAClO}_{4} 0.1 \mathrm{~mol} \cdot \mathrm{dm}^{-3}$ como eletrólito de suporte. Para os estudos de espectroeletroquímica empregou-se soluções $1 \times 10^{-4} \mathrm{~mol} \cdot \mathrm{dm}^{-3}$ das supermoléculas 4TPtTPyP e 3-TPtTPyP em DMF, TEAClO $40.1 \mathrm{~mol} \cdot \mathrm{dm}^{-3}$.

A modificação do eletrodo de carbono vítreo foi realizado pela deposição e lenta evaporação de três camadas de $5 \mu \mathrm{L}$ de 4 -TPtTPyP $5 \times 10^{-4}$ mol.dm ${ }^{-3}$. As soluções de nitrito foram preparadas em tampão acetato com concentrações variando de 1 a $5,2 \times 10^{-3} \mathrm{mmol} \cdot \mathrm{dm}^{-3}$.

\subsubsection{Ressonância magnética nuclear de platina-195}

Os espectros de RMN foram coletados num espectrômetro Bruker $500 \mathrm{MHz}$ empregando-se soluções $10^{-2} \mathrm{~mol} \cdot \mathrm{dm}^{-3}$ das supermoléculas 4-TPtTPyP e 3-TPtTPyP em TFE e uma solução $10^{-2} \mathrm{~mol} \cdot \mathrm{dm}-3$ de $\left[\mathrm{Pt}(\right.$ bipy $\left.) \mathrm{Cl}_{2}\right]$ em DMF. A calibração do sinal foi feita utilizando-se como referência $\mathrm{K}_{2}\left[\mathrm{PtCl}_{4}\right]$ 0,4 mol $\cdot \mathrm{dm}^{-3}$ em $\mathrm{D}_{2} \mathrm{O}$. Os tempos de coleta foram de aproximadamente $10 \mathrm{~h}$ para cada experimento.

\subsubsection{Microscopia de força atômica}

As imagens AFM das espécies foram obtidas usando-se um equipamento PicoSPM Molecular Imaging no modo MACMode com MAClevers tipo II $\left(\mathrm{k}^{\sim} 2,8 \mathrm{~N} / \mathrm{m} ;\left.\right|^{\sim} 60 \mathrm{~Hz}\right)$ também da Molecular Imaging, com uma amplitude de setpoint variando entre 4 e $6 \mathrm{~V}$ sob condições ambiente. A velocidade de varredura foi de 0,3 Hz (para áreas maiores que $5 \mathrm{~mm}^{2}$ ) a $2 \mathrm{~Hz}$ (para áreas menores que $5 \mathrm{~mm}^{2}$ ). As amostras foram preparadas 
depositando-se $5 \mu \mathrm{L}$ de soluções $10^{-4} \mathrm{~mol} \cdot \mathrm{dm}^{-3}$ das supermoléculas em TFE sobre mica high-grade e evaporação ao ar a temperatura ambiente. Esse procedimento foi realizado dentro de uma câmara laminar de fluxo limpo. A mesma metodologia foi empregada para as amostras dos pares iônicos em soluções $10^{-4} \mathrm{~mol} \cdot \mathrm{dm}^{-3}$ em TFE/ $\mathrm{H}_{2} \mathrm{O}$ 2:8.

\subsubsection{Ressonância plasmônica de superfície}

Os dados de SPR foram obtidos em um equipamento Autolab modelo Springle. Empregou-se nesses estudos soluções das supermoléculas e de DNA com concentrações $1,6 \times 10^{-6} \mathrm{~mol} \cdot \mathrm{dm}^{-3}$ e $9,3 \times 10^{-5} \mathrm{~mol} \cdot \mathrm{dm}^{-3}$, respectivamente. Essas soluções foram preparadas em tampão Tris- $\mathrm{HCl}, \mathrm{pH}=7,4$, a $10 \%$ de TFE e com força iônica constante, determinada pela presença de $50 \mathrm{mM}$ de $\mathrm{NaCl}$.

A imobilização das espécies foi realizada segundo metodologia descrita a seguir: Inicialmente a superfície de ouro foi modificada por imersão em uma solução aquosa 10 $\mathrm{mmol} \cdot \mathrm{dm}^{-3}$ de cloreto de cisteamina por $24 \mathrm{~h}$. Após adicionou-se $200 \mu \mathrm{L}$ da solução de DNA e acompanhou-se o processo de interação por SPR. Verificado o fim do processo de adsorção de DNA sobre a superfície de Au previamente modificada com cisteamina, drenou-se a solução de DNA da cela e verteu-se $200 \mu \mathrm{L}$ da solução dos complexos. 


\section{Capítulo 3}

\section{Resultados e Discussões}

\subsection{Análise Térmica}

As supermoléculas, por serem espécies de tamanho e carga elevada, tendem a precipitar com um teor elevado de águas de hidratação. Por esse motivo, a análise térmica foi empregada com o objetivo principal de confirmar o número de moléculas de águas verificado na análise elementar dos complexos.

A figura 3.1 apresenta a curva termogravimétrica para a $\left[\mathrm{Pt}(\right.$ bipy $\left.) \mathrm{Cl}_{2}\right]$. A decomposição desse complexo tem início em $350^{\circ} \mathrm{C}$ e vai até $900^{\circ} \mathrm{C}$, temperatura limite da técnica. Cálculos estequiométricos tomados ao longo da curva, correlacionando-se o percentual de perda de massa à massa molar dos complexos, indicam que se obtém platina elementar ao final do experimento, de modo que as diferentes regiões do termograma referem-se a decomposição do ligante bipiridina e perda dos cloretos. Vale salientar que esse comportamento é típico para complexos de metais nobres.

A termodegradação da 3-TPyP tem início em $426^{\circ} \mathrm{C}$ e a dTG revela um processo de perda massa que ocorre a $495^{\circ} \mathrm{C}$, seguido de uma região de decomposição contínua até $900^{\circ} \mathrm{C}$. Esses resultados estão ilustrados na figura 3.2 .

Como o termograma da 3-TPyP não possui regiões de estabilização referente a formação de produtos intermediários de decomposição, não foi possível fazer uma atri- 


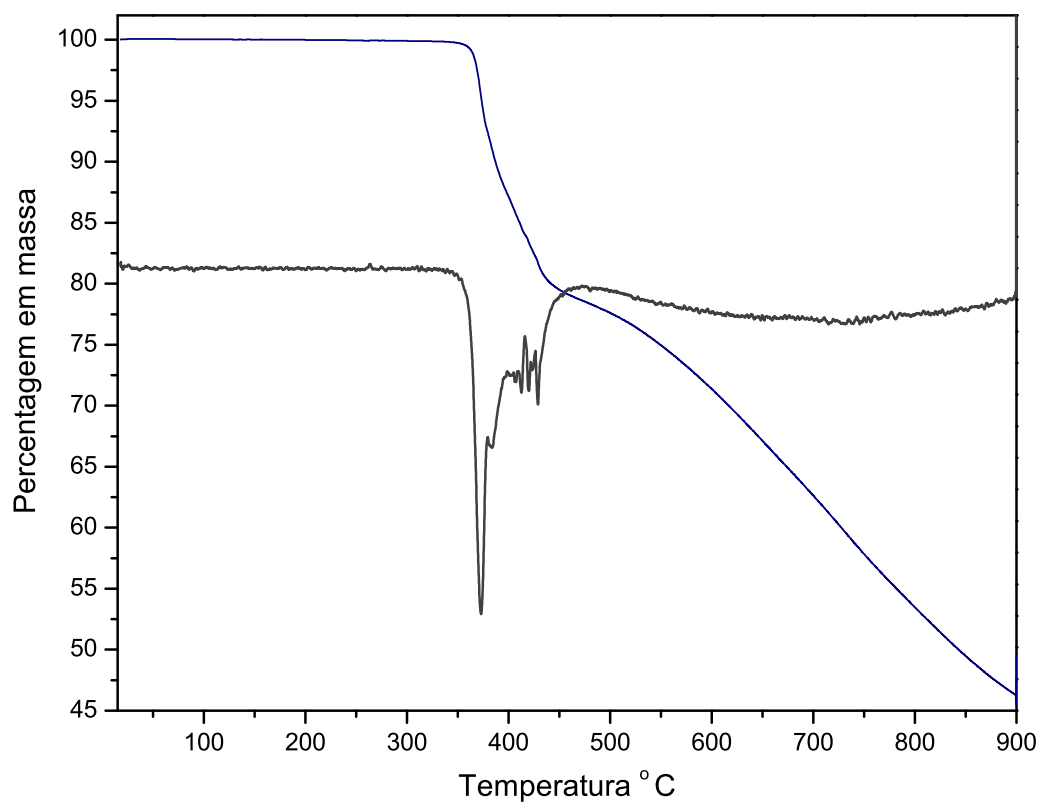

Figura 3.1: Curva termogravimétrica e dTG para [Pt(bipy) $\left.\mathrm{Cl}_{2}\right]$.

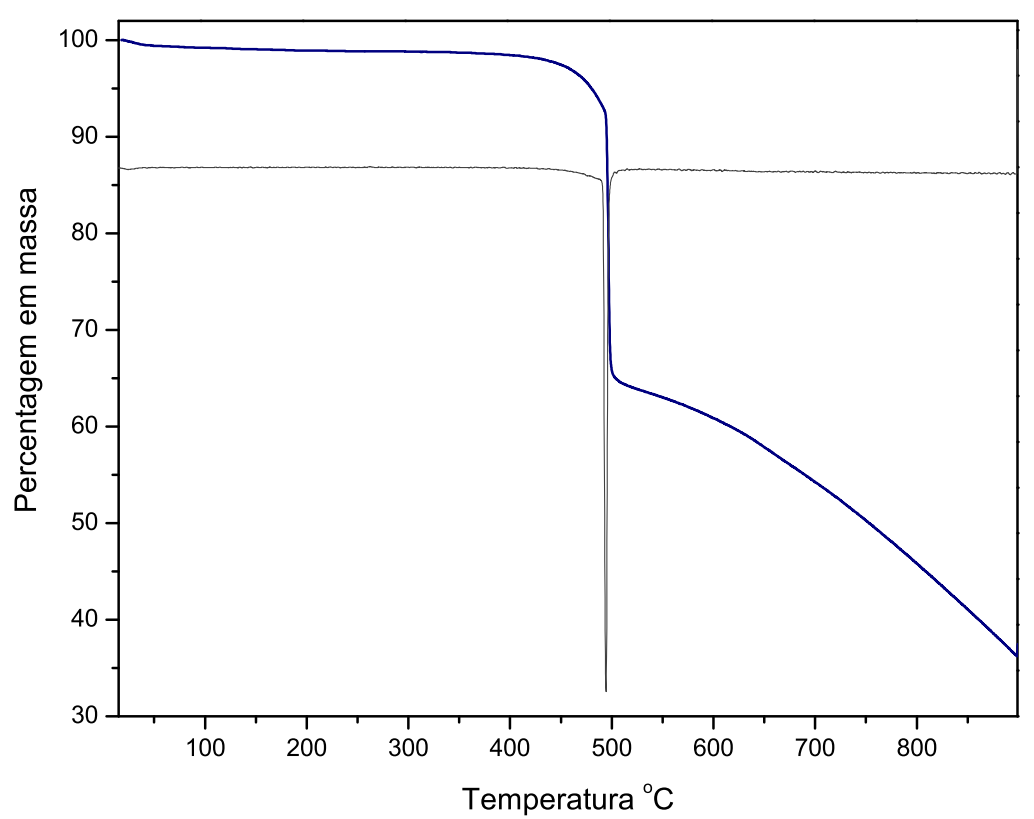

Figura 3.2: Curva termogravimétrica e dTG para 3-TPyP. 
buição adequada da perda de massa em toda a faixa do experimento. Cálculos estequiométricos preliminares sugerem que a perda de massa vinculada ao pico da primeira derivada corresponde a decomposição de três meso-piridinas do anel porfirínico.

Na figura 3.3 tem-se as curvas termogravimétricas para as duas novas supermoléculas. Neste caso a dTG das curvas revela dois processos principais de perda de massa, sendo que o primeiro corresponde a perda de água. De modo similar ao observado para a 3-TPyP, há uma região contínua de decomposição nas temperaturas mais elevadas, tornando ainda mais difícil uma atribuição tentativa das perdas de massa. Os processos de decomposição tem início em regiões próximas para os dois isômeros, ocorrendo a $326^{\circ} \mathrm{C}$ para a 4 -TPtTPyP e a $320^{\circ} \mathrm{C}$ para a 3 -TPtTPyP.

$\mathrm{Na}$ faixa de temperatura correspondente a perda de água observa-se uma variação de $-6 \%$ na massa da amostra. Baseado na correlação entre a massa molar das supermoléculas e esse percentual de perda, chega-se a uma razão de 8 moléculas de água por supermolécula, tal como proposto nos resultados da análise elementar. 


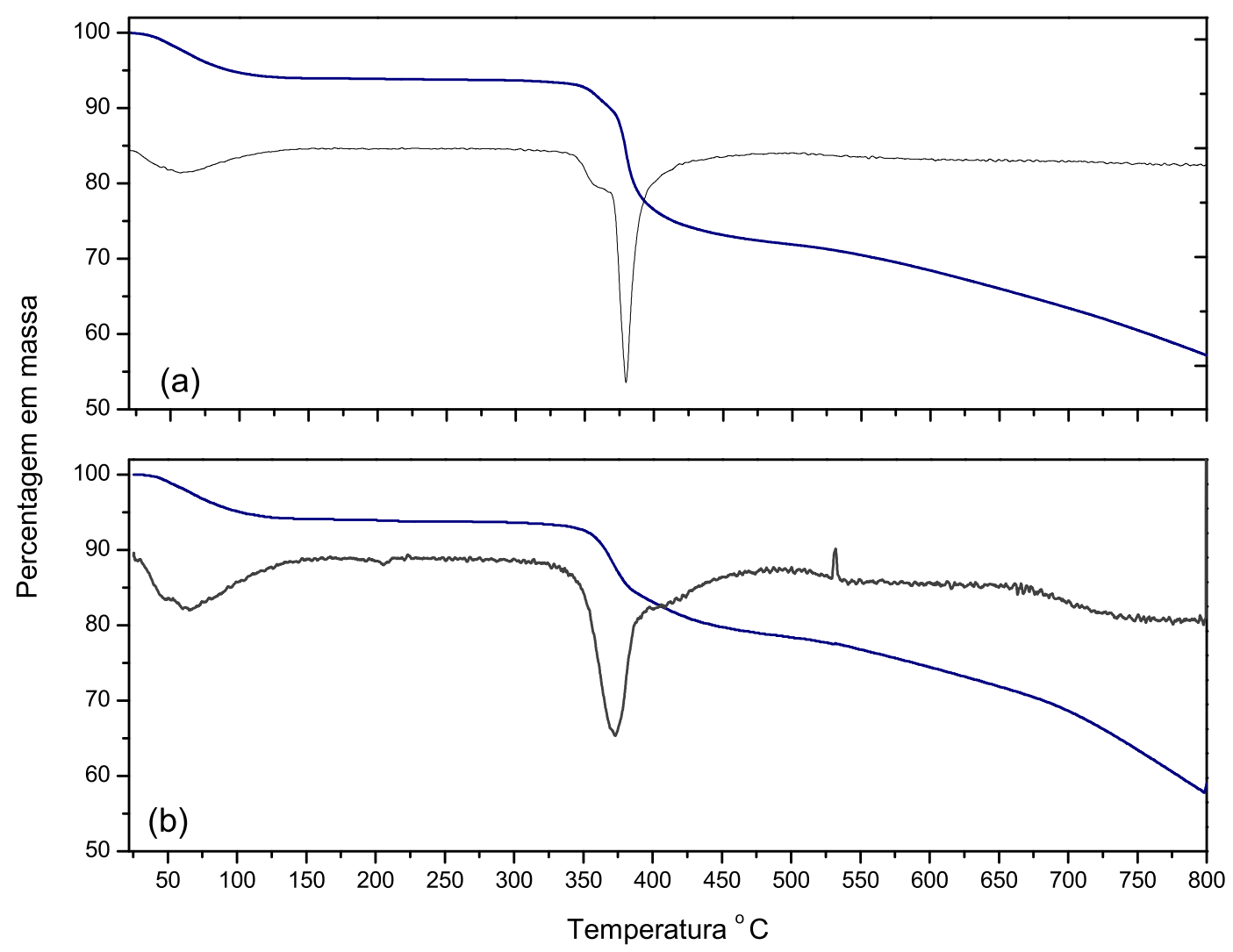

Figura 3.3: Curvas termogravimétricas e dTG para a) 3-TPtTPyP e b) 4-TPtTPyP. 


\subsection{Espectrometria de Massa com Ionização por Spray de Elétrons}

Com o advento da técnica de ionização por spray de elétrons, a espectrometria de massa vem se firmando como uma método de análise instrumental extremamente útil na caracterização de sistemas super e supramoleculares [208]. Propriedades típicas desses sistemas como carga, massa e tamanho elevados, aliada a baixa solubilidade em solventes deuterados comuns tornam estes compostos de difícil caracterização via técnicas tradicionais como $\mathrm{RMN}^{1} \mathrm{H}$ e espectrometria de massa por impacto de elétrons.

Uma das principais vantagens desta técnica é que ela proporciona um método de ionização brando capaz de transferir de modo efetivo da solução para a fase gasosa espécies catiônicas e aniônicas não voláteis. Essa característica somada a capacidade de selecionar-se íons moleculares específicos (ESI-MS/MS), tem permitido a elucidação estrutural de várias espécies carregadas [208-210].

Os dados de ESI-MS obtidos para as novas supermoléculas de tetrapiridilporfirinas associadas a complexos bipiridínicos de platina(II) são consistentes com as estruturas propostas. Esses resultados foram próximos para os dois isômeros e são discutidos a seguir.

Nas figuras 3.4 e 3.5 é apresentado o padrão de fragmentação esperado e os valores teóricos de $\mathrm{m} / \mathrm{z}$ para os dois isômeros, demonstrando a formação de íons moleculares com carga variando de +4 a +1 . Como será demonstrado a seguir, todos esses íons puderam ser detectados por ESI-MS no modo íon positivo com o auxílio de técnicas de dissociação induzida por colisão.

A figura 3.6, página 62, traz os espectros de massa adquiridos no modo íon positivo após o processo de elétron spray de soluções de 4-TPtTPyP e 3-TPtTPyP em metanol. Para a 4-TPtTPyP observa-se que o fragmento $4 \mathrm{a}(4+)$ (figura 3.4) é eficientemente transferido para a fase gasosa e detectado como o íon mais abundante, seguido de perto pelo íon $4 \mathrm{~b}(3+)$. A mesma situação não é verificada para a 3-TPtTPyP, onde o 


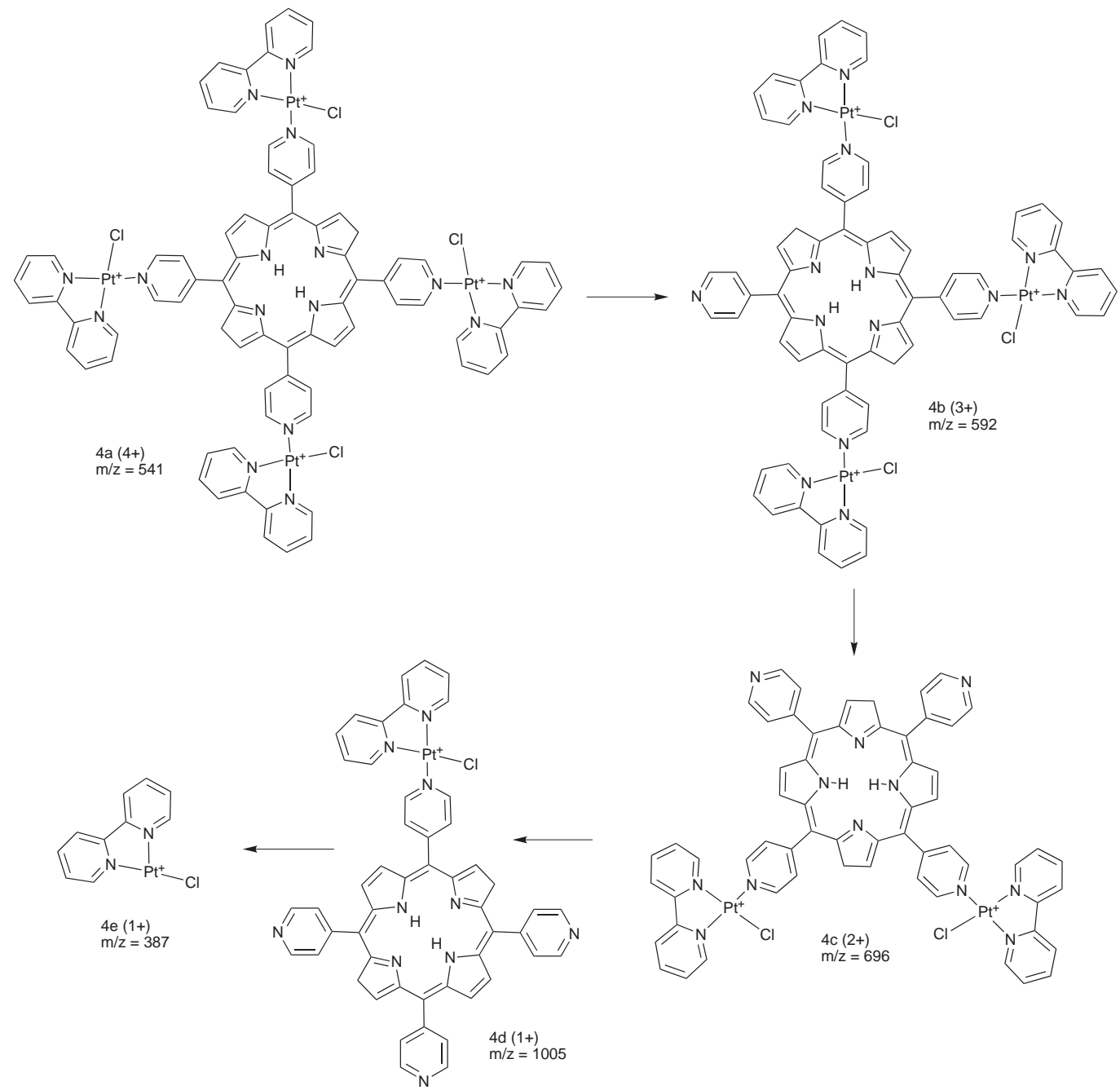

Figura 3.4: Padrão de fragmentação esperado para 4-TPtTPyP. 

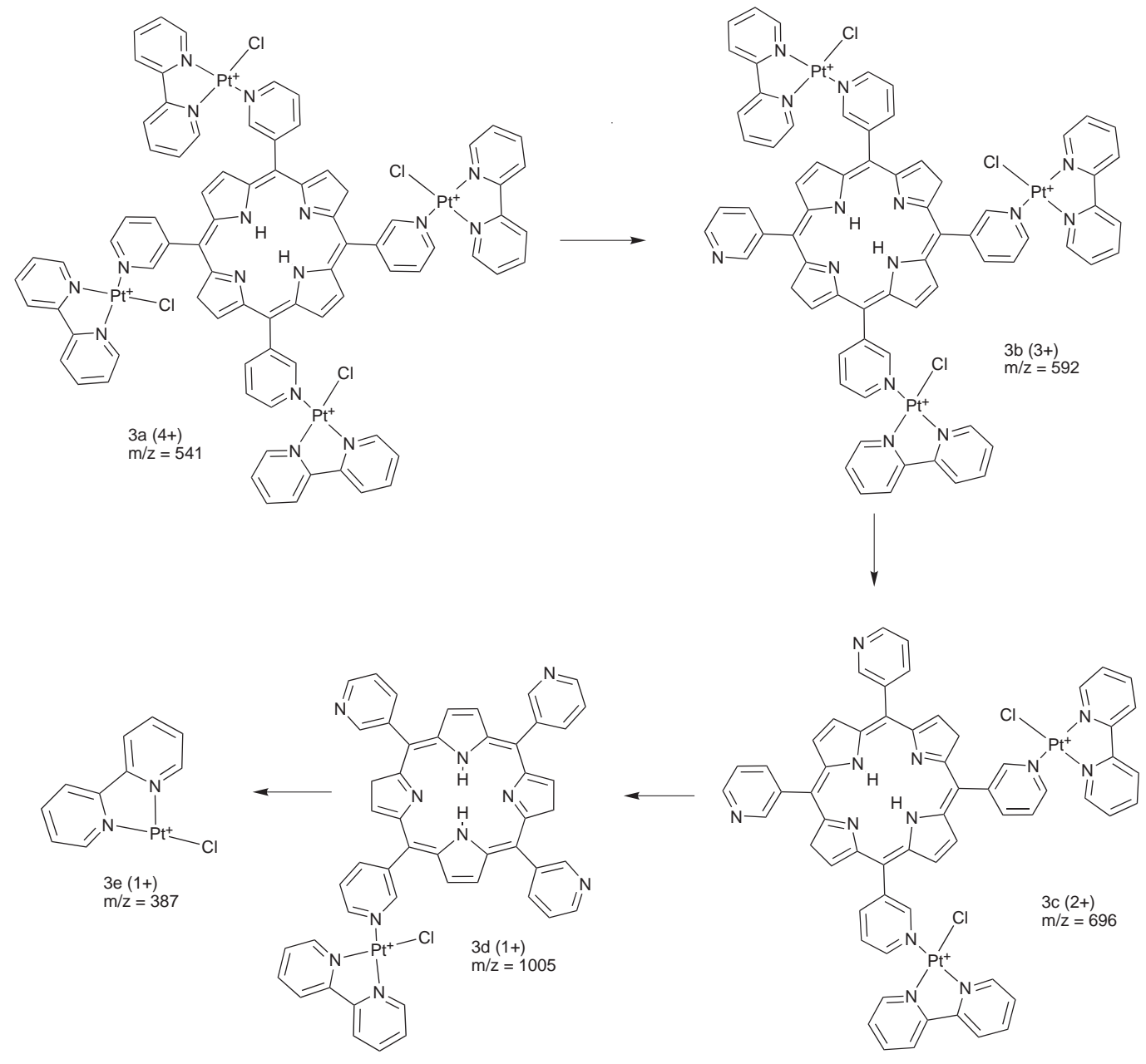

Figura 3.5: Padrão de fragmentação esperado para 3-TPtTPyP. 
pico m/z 100\% corresponde ao íon 3c(2+) (figura 3.5), seguido pelo pico do íon $3 \mathrm{~b}(3+)$. Nesta espécie, o pico m/z referente ao íon $3 \mathrm{a}(4+)$ aparece com uma abundância relativa de apenas $10 \%$.

Os íons $4 \mathrm{a}(4+), 4 \mathrm{~b}(3+), 3 \mathrm{a}(4+)$ e $3 \mathrm{~b}(3+)$ foram isolados via seleção de massas para elucidação estrutural por ESI-MS/MS e os resultados estão apresentados nas figuras 3.7 e 3.8. Nessas figuras é claramente demonstrada a presença de íons moleculares com valores de $\mathrm{m} / \mathrm{z}$ consistentes com as estruturas dos fragmentos iônicos das supermoléculas mostrados nas figuras 3.4 e 3.5. Tanto para a 4-TPtTPyP como para a 3-TPtTPyP observou-se uma separação de picos m/z $(\Delta \mathrm{m} / \mathrm{z})$ idêntica.

Alguns picos $\mathrm{m} / \mathrm{z}$ não vinculados às espécies mono, di, tri e tetra-coordenadas observados nos espectros de massa da figura 3.6 estão associados à formação de espécies intermediárias de fragmentação, podendo ser originados pela combinação entre íons moleculares das supermoléculas com os ânions cloreto. O pico m/z 733,99 por exemplo, o qual aparece nos espectros dos dois isômeros, quando isolado para estudo por ESI-MS/MS apresenta como principal produto de fragmentação a espécie de razão carga/massa 592, a qual corresponde aos íons moleculares $4 \mathrm{~b}(3+)$ e $3 \mathrm{~b}(3+)$.

A tabela 3.1 resume os principais resultados de ESI-MS discutidos acima.

Tabela 3.1: Valores de $\mathrm{m} / \mathrm{z}$ e $\Delta(\mathrm{m} / \mathrm{z})$ obtido nos espectros ESI-MS das supermoléculas 4-TPtTPyP (4) e 3-TPtTPyP (3).

\begin{tabular}{l|r|c|r}
\hline Ion molecular & $\mathrm{MM}\left(\mathrm{g} . \mathrm{mol}^{-1}\right)$ & $\mathrm{m} / \mathrm{z}$ & $\Delta(\mathrm{m} / \mathrm{z})$ \\
\hline \hline$(4)\left[C_{40} H_{26} N_{8}\left\{P t C_{10} H_{8} N_{2} C l\right\}_{4}\right]^{4+}$ & 2165,58 & 541,75 & 0,25 \\
(4) $\left[C_{40} H_{26} N_{8}\left\{P t C_{10} H_{8} N_{2} C l\right\}_{3}\right]^{3+}$ & 1778,86 & 592,91 & 0,33 \\
$(4)\left[C_{40} H_{26} N_{8}\left\{P t C_{10} H_{8} N_{2} C l\right\}_{2}\right]^{2+}$ & 1392,10 & 696,34 & 0,55 \\
$(4)\left[C_{40} H_{26} N_{8}\left\{P t C_{10} H_{8} N_{2} C l\right\}_{1}\right]^{1+}$ & 1005,42 & 1005,51 & 1,00 \\
$(3)\left[C_{40} H_{26} N_{8}\left\{P t C_{10} H_{8} N_{2} C l\right\}_{4}\right]^{4+}$ & 2165,58 & 541,18 & 0,25 \\
$(3)\left[C_{40} H_{26} N_{8}\left\{P t C_{10} H_{8} N_{2} C l\right\}_{3}\right]^{3+}$ & 1778,86 & 592,87 & 0,33 \\
$(3)\left[C_{40} H_{26} N_{8}\left\{P t C_{10} H_{8} N_{2} C l\right\}_{2}\right]^{2+}$ & 1392,10 & 695,80 & 0,55 \\
$(3)\left[C_{40} H_{26} N_{8}\left\{P t C_{10} H_{8} N_{2} C l\right\}_{1}\right]^{1+}$ & 1005,42 & 1005,51 & 1,00 \\
{$\left[P t C_{10} H_{8} N_{2} C l\right]^{+}$} & 386,72 & 387,11 & 1,00 \\
\hline
\end{tabular}



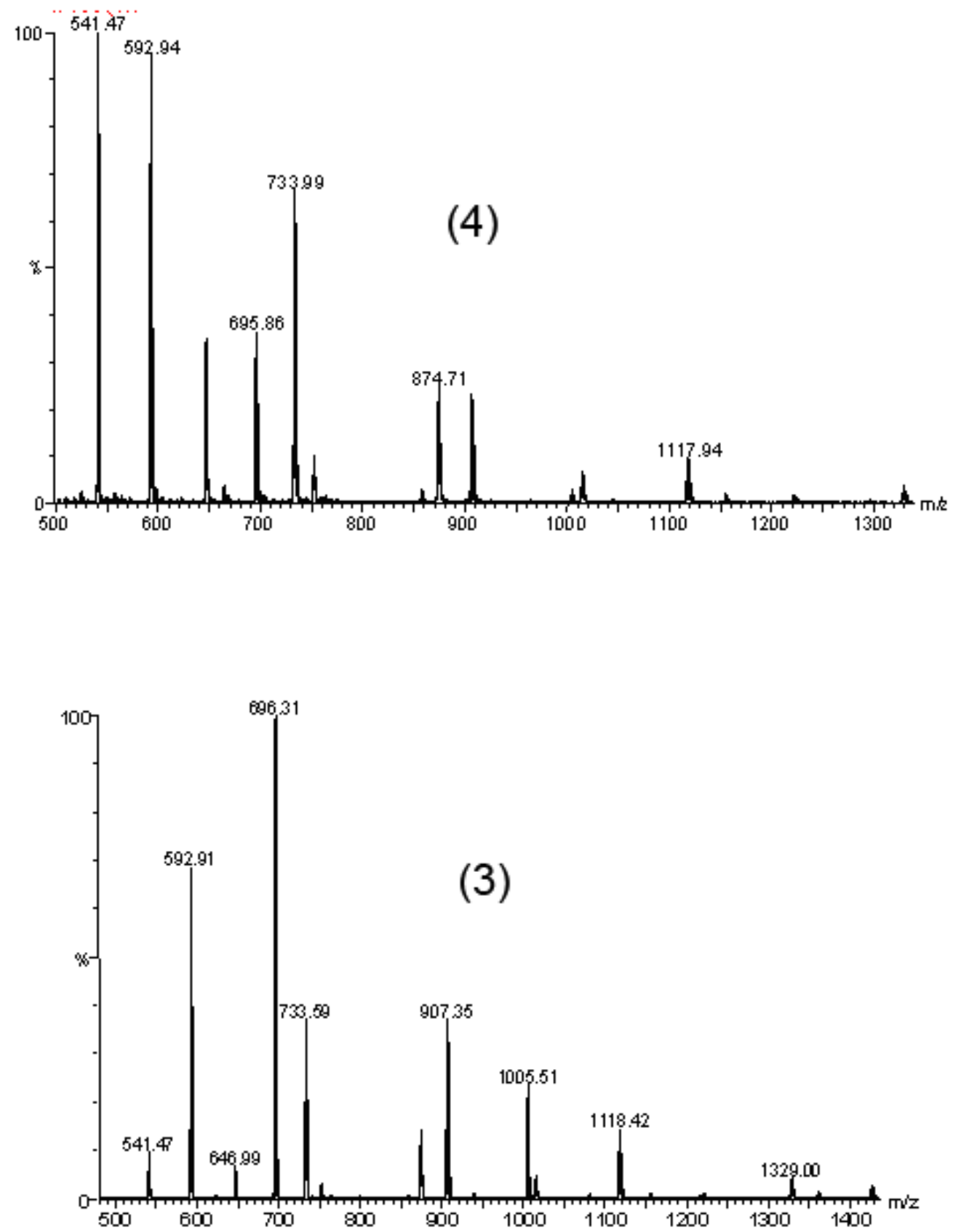

Figura 3.6: Espectros ESI-MS no modo íon positivo para 4-TPtTPyP (4) e 3TPtTPyP (3). 

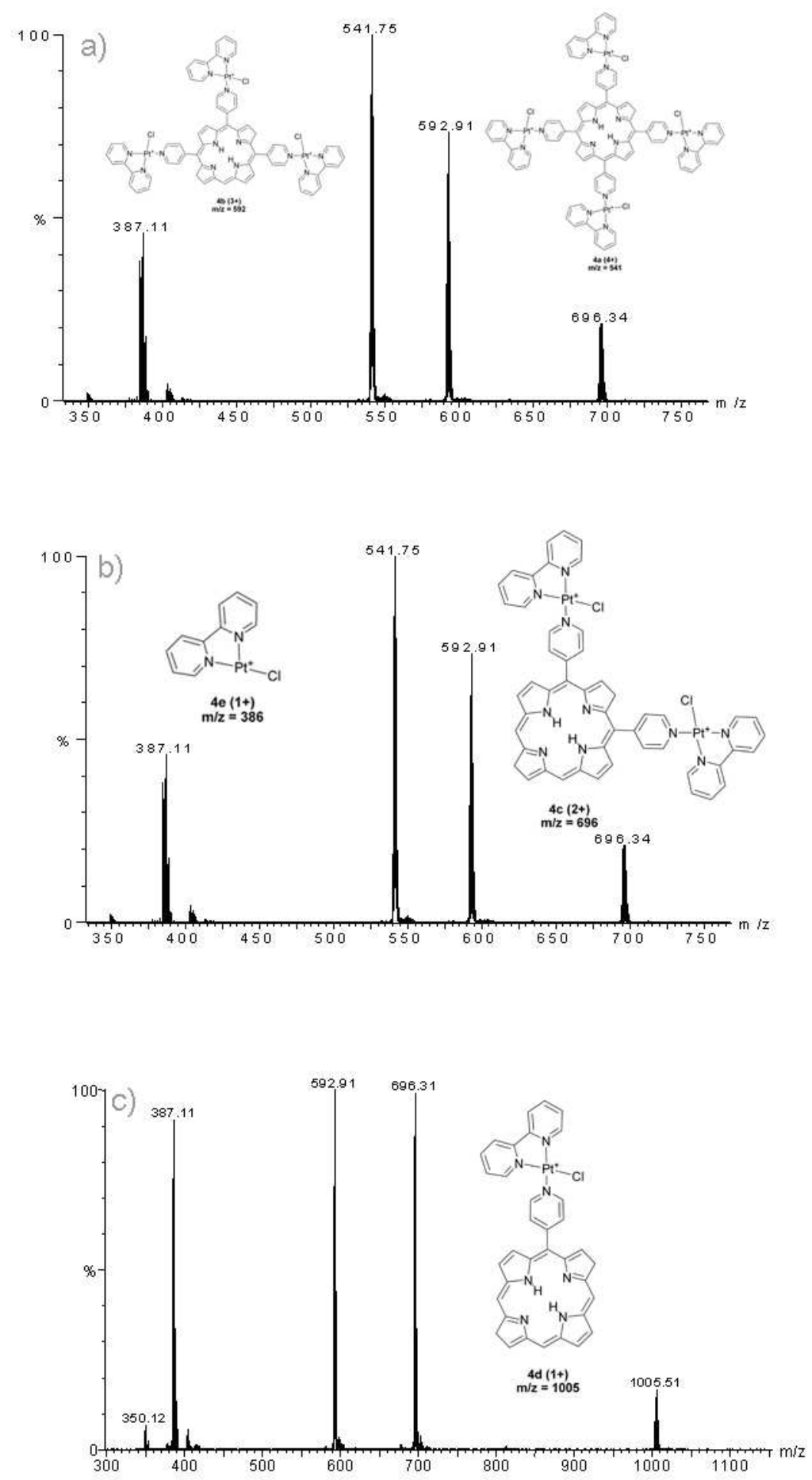

Figura 3.7: a) e b): ESI-MS/MS do íon de $\mathrm{m} / \mathrm{z} 541(\mathrm{CE}=12)$. c) ESI-MS/MS do íon de $\mathrm{m} / \mathrm{z} 592(\mathrm{CE}=20)$. 

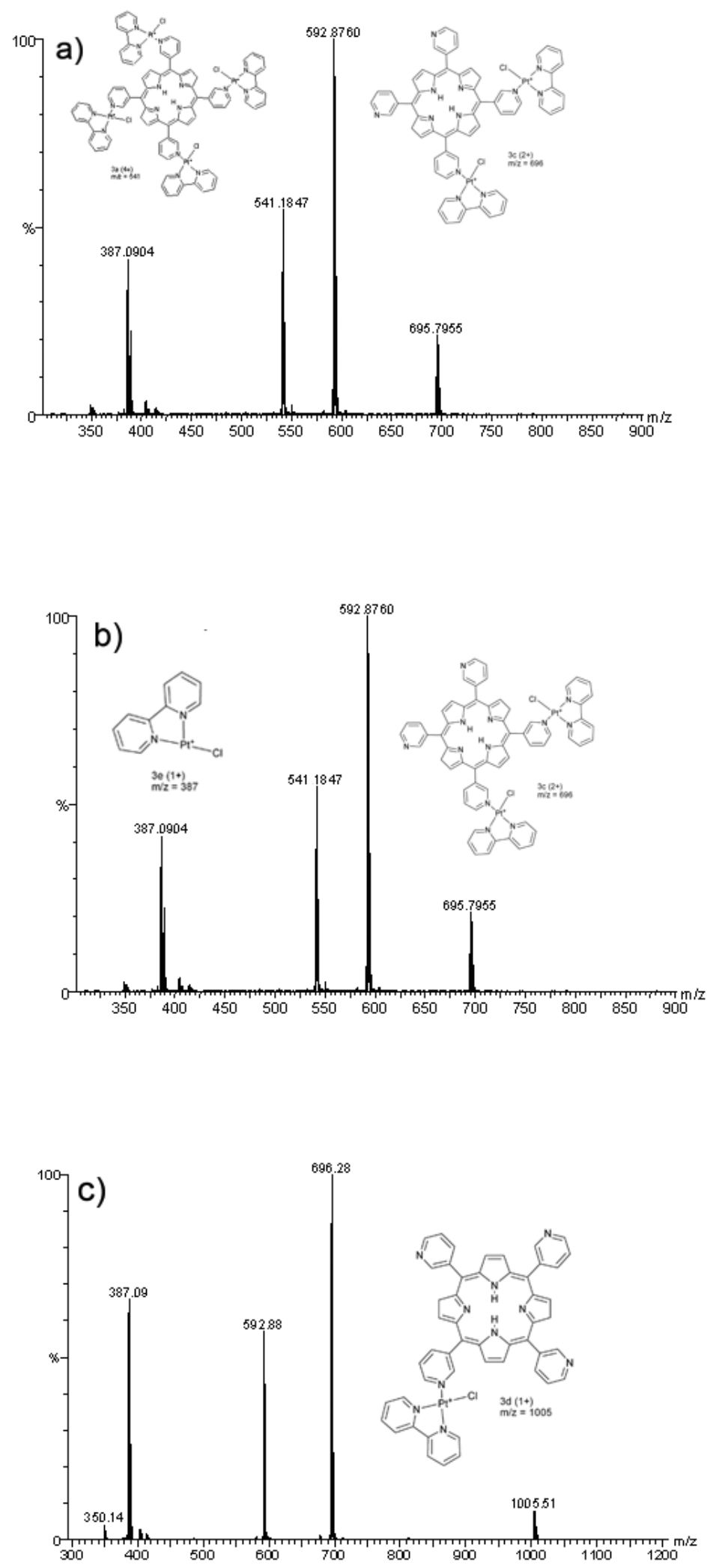

Figura 3.8: a) e b): ESI-MS/MS do íon de $\mathrm{m} / \mathrm{z} 541(\mathrm{CE}=12)$. c) ESI-MS/MS do íon de $\mathrm{m} / \mathrm{z} 592(\mathrm{CE}=12)$. 


\subsection{Ressonância Magnética Nuclear de Platina-195}

A ${ }^{195} \mathrm{Pt}$ é o núcleo mais estudado por ressonância magnética nuclear na família do níquel [211]. Corrobora para isso o fato de ser um isótopo relativamente abundante quando comparado aos outros centros metálicos, sendo um núcleo moderadamente sensível. Esse núcleo possui spin 1/2 e abundância natural igual a 33,7\% [211].

A sensibilidade desse núcleo para a estrutura molecular é suficiente para assegurar que há baixa sobreposição de sinais, permitindo a separação de isômeros geométricos e estéreo-isômeros, especialmente para complexos de platina com configuração cis, trans [211]. Por isso, as medidas de RMN de ${ }^{195} \mathrm{Pt}$ podem ser empregadas na determinação do número de ambientes químicos diferentes que cercam o núcleo ${ }^{195} \mathrm{Pt}$, na verificação dos tipos de ligantes coordenados através do deslocamento químico observado e na determinação da simetria local do centro metálico [211].

Para calibração do sinal não há um composto ideal que sirva como padrão, isto é, que seja de fácil acesso em termos de custo e disponibilidade, inerte e facilmente mensurável. Geralmente emprega-se $\mathrm{K}_{2} \mathrm{PtCl}_{6}$ em $\mathrm{D}_{2} \mathrm{O}$ como referência [211]. Em nosso caso, entretanto, a calibração do sinal foi feita contra $\mathrm{K}_{2} \mathrm{PtCl}_{4}$ em $\mathrm{D}_{2} \mathrm{O}$.

As primeiras observações por RMN do núcleo platina-195 datam do final da década de 60 [212,213], mas este nos parece ser um dos primeiros exemplos reportando a medida do espectro de ${ }^{195} \mathrm{Pt}$ para complexos de platina(II)-porfirina de caráter supramolecular.

Dados da literatura reportam a ocorrência do sinal para o complexo $\left[\mathrm{Pt}(\right.$ bipy $\left.) \mathrm{Cl}_{2}\right]$ a -2315 ppm. O espectro deste complexo obtido em DMF é apresentado na figura 3.9, onde observa-se um pico singlete a -2319 ppm. Pela adição de um pequeno excesso de [Pt(bipy) $\left.\mathrm{Cl}_{2}\right]$ na solução da supermolécula 3-TPtTPyP em TFE percebe-se que este sinal é ocorre a -2322 ppm neste solvente.

As supermoléculas também apresentam um sinal singlete, só que a -2401 ppm em ambos os casos, conforme pode ser verificado na figura 3.9. Ou seja, todos os centros metálicos estão num ambiente de coordenação equivalente e prevalecem espécies tetracoordenadas no meio. Como os tipos de ligantes coordenados à platina(II) e a 
simetria local do centro metálico são idênticos em ambos os casos, não ocorre deslocamento de sinal nos dois isômeros. O deslocamento de -79 ppm observado em relação ao complexo precursor denota que a coordenação do fragmento $\mathrm{Pt}($ bipy $) \mathrm{Cl}^{+}$à porfirina aumenta a nuvem eletrônica sobre o núcleo metálico, aumentando assim a blindagem sobre o mesmo.
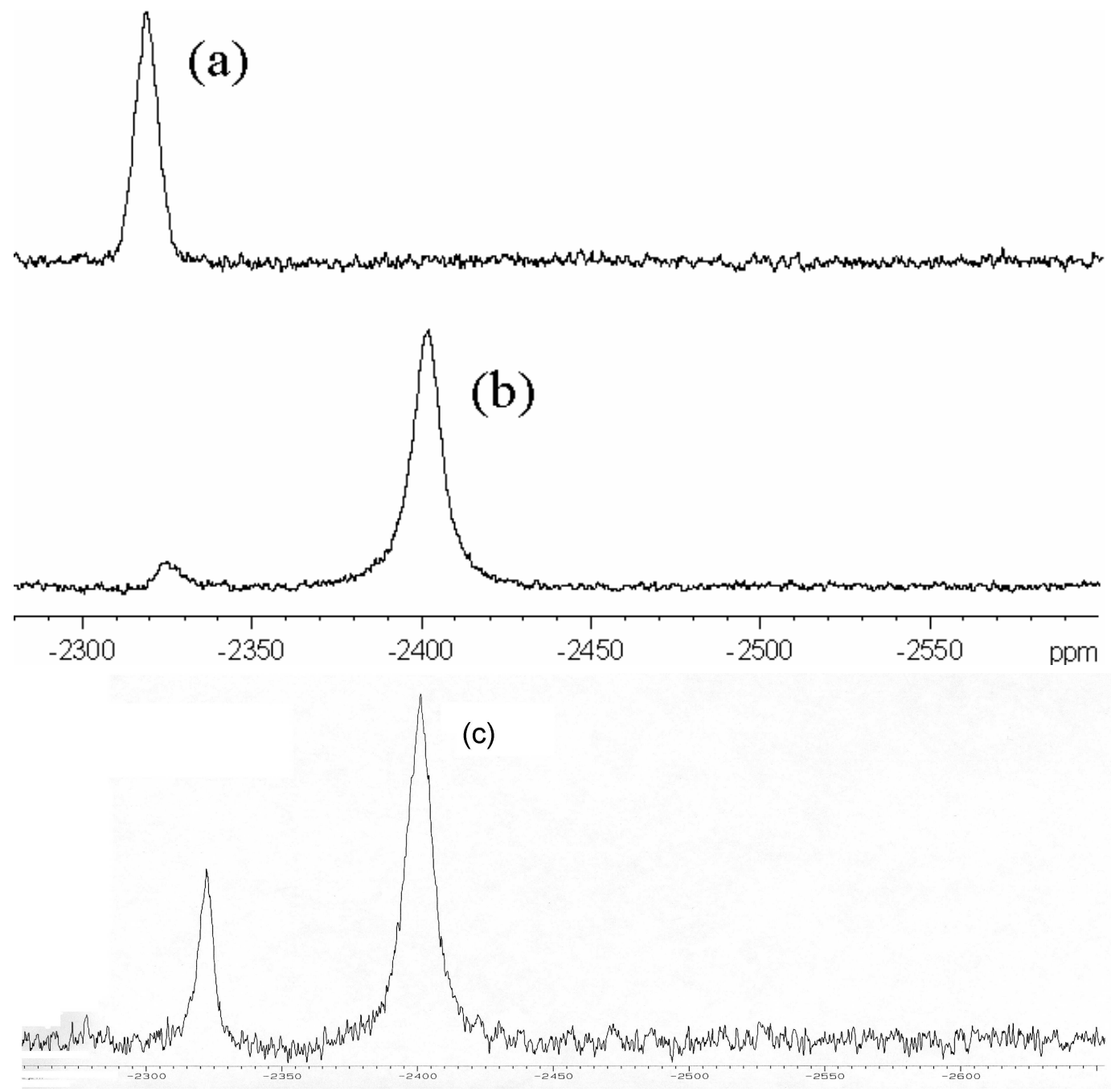

Figura 3.9: Espectros de ${ }^{195} \mathrm{Pt} \mathrm{RMN} 500 \mathrm{MHz}$ das espécies (a) $\left[\mathrm{Pt}\right.$ (bipy) $\left.\mathrm{Cl}_{2}\right] \quad 0,4$ $\mathrm{mol} \cdot \mathrm{dm}^{-3}$ em DMF (b) 4-TPtTPyP $2 \times 10^{-2} \mathrm{~mol} \cdot \mathrm{dm}^{-3}$ em TFE e (c) 3-TPtTPyP $2 \mathrm{x}$ $10^{-2} \mathrm{~mol} \cdot \mathrm{dm}^{-3}$ em TFE contendo $\left[\mathrm{Pt}(\right.$ bipy $\left.) \mathrm{Cl}_{2}\right]$ em excesso. 


\subsection{Espectroscopia Vibracional}

Na figura 3.10 são apresentados os espectros no infravermelho das supermoléculas 4-TPtTPyP, 3-TPtTPyP, da porfirina base-livre 4-TPyP e do complexo diimínico de platina(II). O espectro da 3-TPyP é idêntico ao seu isômero e por isso foi omitido.

As bandas da bipiridina na região do infravermelho médio (4000 a $400 \mathrm{~cm}^{-1}$ ) são pouco sensíveis a coordenação. Desse modo, o espectro do complexo $\left[\mathrm{Pt}(\right.$ bipy $\left.) \mathrm{Cl}_{2}\right]$ é dominado pelas vibrações fundamentais do ligante. Assim, na região de $3060 \mathrm{~cm}^{-1}$ são observados os estiramentos $\nu_{C-H}$ sim e $\nu_{C-H}$ assim aromáticos. Entre 1606 e $1448 \mathrm{~cm}^{-1}$ tem-se as bandas de deformação axial atribuídas a $\nu_{C=C}, \nu_{C=N}$ e deformação do anel. A $757 \mathrm{~cm}^{-1}$ observa-se a banda de deformação angular fora do plano $\delta_{C-H}$ [214-216].

As porfirinas possuem um padrão de absorção bastante complexo no infravermelho, e mesmo uma porfirina simples não substituída como a porfina (equivale ao anel central da TPyP), possui 105 modos de vibração fundamental [214]. O espectro IV desses anéias são marcados por bandas fortemente acopladas entre si e por bandas de respiração do anel na região de 600 a $2000 \mathrm{~cm}^{-1}$ do espectro.

As bandas observadas entre 1660 e $650 \mathrm{~cm}^{-1}$ para a 4-TPyP na figura 3.10 são devidas a $\nu_{C-C}, \nu_{C=C}, \nu_{C-N}, \nu_{C=N}, \nu_{C=C}, \delta_{C-H}$ e $\delta_{C-C-N}$. Apesar de não estar mostrado na figura, verifica-se ainda uma banda forte e alargada a $3420 \mathrm{~cm}^{-1}$ devido a $\nu_{N-H}$.

Os espectros no infravermelho dos compostos 4-TPtTPyP e 3-TPtTPyP possuem um perfil equivalente a somatória dos espectros da $\left[\mathrm{Pt}\left(\right.\right.$ bipy $\left.\mathrm{Cl}_{2}\right]$ e das respectivas porfirinas 4-TPyP e 3-TPyP, promovendo apenas pequenos deslocamentos e variação na intensidade relativa das bandas. Esses espectros apresentam ainda uma banda intensa e larga a $3410 \mathrm{~cm}^{-1}$ referente aos estiramentos $\nu_{O-H}$, uma vez que estes complexos apresentam águas de hidratação na esfera de coordenação. 


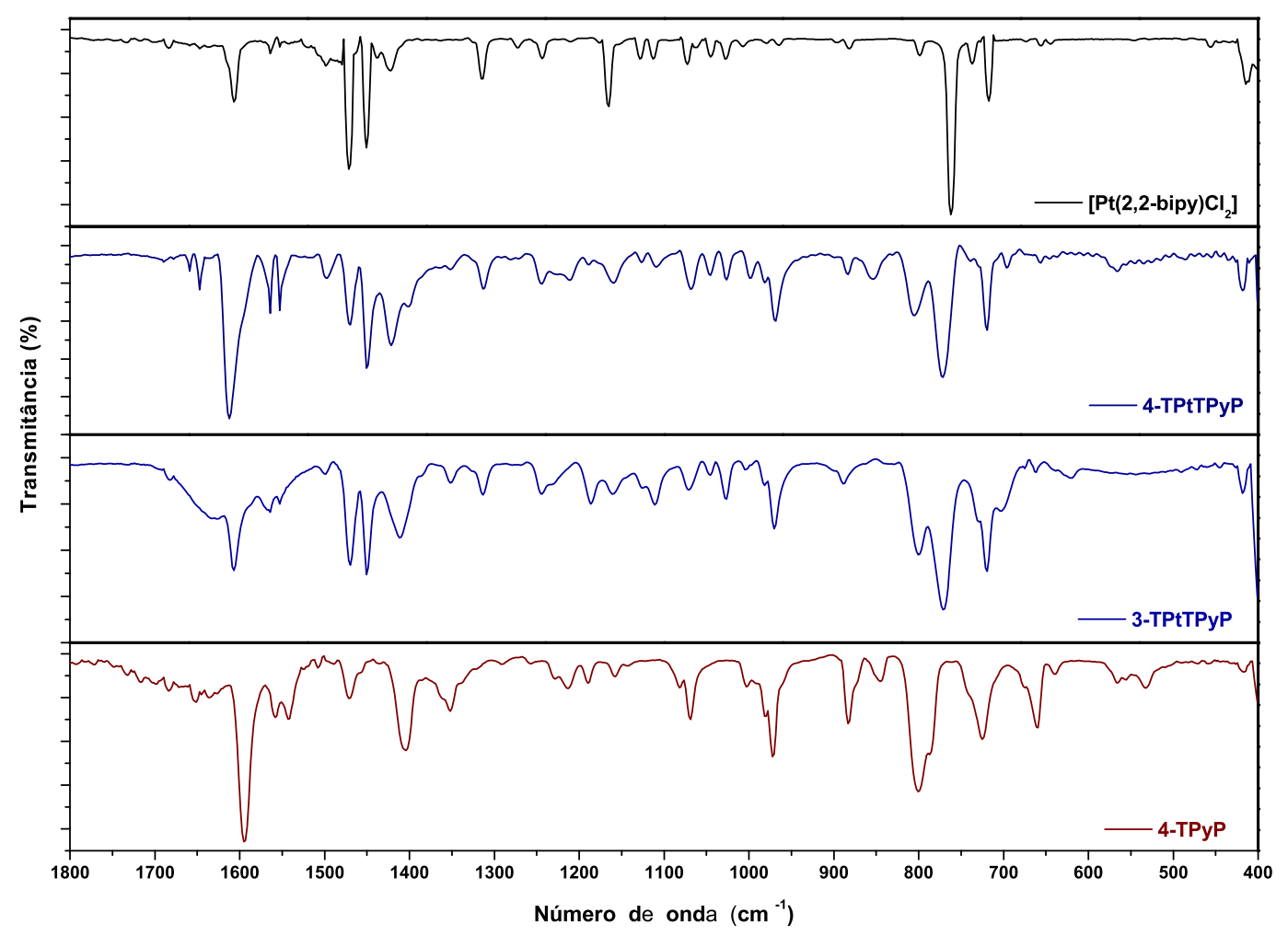

Figura 3.10: Espectros no infravermelho para os compostos $\left[\mathrm{Pt}\left(\right.\right.$ bipy) $\left.\mathrm{Cl}_{2}\right]$, 4TPtTPyP, 3-TPtTPyP e 4-TPyP. 


\subsection{Modelagem Molecular}

No início deste trabalho um dos objetivos propostos era obter-se monocristais das novas supermoléculas para análise por difração de raios-X. Porém, a tendência que estas espécies tem em formar filmes moleculares acaba atuando como um fator limitante no crescimento de cristais. Apesar da nucleação de um cristal ser favorecida pela presença de cargas localizadas e espacialmente distribuídas, tal como ocorre nestas supermoléculas, acreditamos que o tamanho das mesmas acaba atuando como um aspecto restritivo, tornando o arranjo cristalino entropicamente desfavorável. Assim, a obtenção de monocristais para análise por difração de raios-X tem se revelado extremamente difícil.

Dados da literatura confirmam esta observação, uma vez que publicações reportando a obtenção de estruturas cristalinas de piridilporfirinas polimetaladas exociclicamente são raras. No caso das tetrapiridilporfirinas tetrarutenadas e tetraplatinadas, a cristalização permanece como um desafio a ser superado.

Entretanto, as informações estruturais das supermoléculas são de fundamental importância para a compreensão de suas propriedades e avaliação de potenciais aplicações. Ainda mais quando se considera o caso de estruturas isoméricas, já que a geometria é a única característica que as difere.

Para contornar essa dificuldade e chegar-se a dados do arranjo espacial das estruturas, fez-se uso de cálculos teóricos para prever a geometria adotada pelas supermoléculas, empregando métodos de mecânica molecular e DFT, conforme descrito na parte experimental. Vale salientar que o estágio em que se encontra a química computacional atualmente já nos permite a obtenção de resultados bastante confiáveis e passíveis de teste pela comparação dos modelos teóricos com a estrutura cristalina de complexos platinados e porfirínicos mononucleares. Inclusive, este foi o método empregado para validar a geometria obtida por mecânica molecular para as supermoléculas, onde se comparou a estrutura obtida com a estrutura cristalina/molecular de complexos diimínicos de platina(II) disponíveis na literatura. Uso-se como fonte principal dados 
estruturais disponíveis na base eletrônica dos periódicos Acta Crystallographica Section C and Acta Crystallographica Section E [217]. Para maiores detalhes consulte a referência [205].

As figuras 3.11 e 3.12 apresentam as geometrias otimizadas para os dois novos compostos. Na geometria da 4-TPtTPyP observamos uma conformação essencialmente planar, com os grupos Pt(II)-bipy coplanares ao plano da porfirina e os aneís piridínicos a um ângulo de aproximadamente $90^{\circ}$ em relação ao anel porfirínico. Já na 3-TPtTPyP os grupos Pt(II)-bipy encontram-se numa conformação fora do plano, localizados acima e abaixo do plano do anel porfirínico, numa geometria do tipo cela.

Enquanto a 4-TPtTPyP deve possuir uma relativa liberdade rotacional em torno do eixo da ligação Pt-N, o impedimento estérico na 3-TPtTPyP deve manter esta conformação fixa, com os anéis piridínicos a um ângulo estável de $90^{\circ}$ em relação ao plano do anel porfirínico.

O cálculo dos orbitais moleculares mostra que o HOMO e o LUMO das duas supermoléculas estão centrados no anel porfirínico e o diagrama de orbitais corresponde ao modelo de quatro orbitais de fronteira envolvidos nas transições eletrônicas Soret e Q, o que será discutido mais detalhadamente nos resultados de espectroscopia eletrônica. A figura 3.13 mostra a representação destes orbitais para as supermoléculas 4-TPtTPyP e 3-TPtTPyP. Conforme será visto posteriormente, estes resultados estão de acordo com dados obtidos experimentalmente para as medidas espectroscópicas e eletroquímicas. Eles também coincidem com os modelos de orbitais moleculares obtidos para complexos porfirínicos polinucleares de rutênio(II) [205]. 

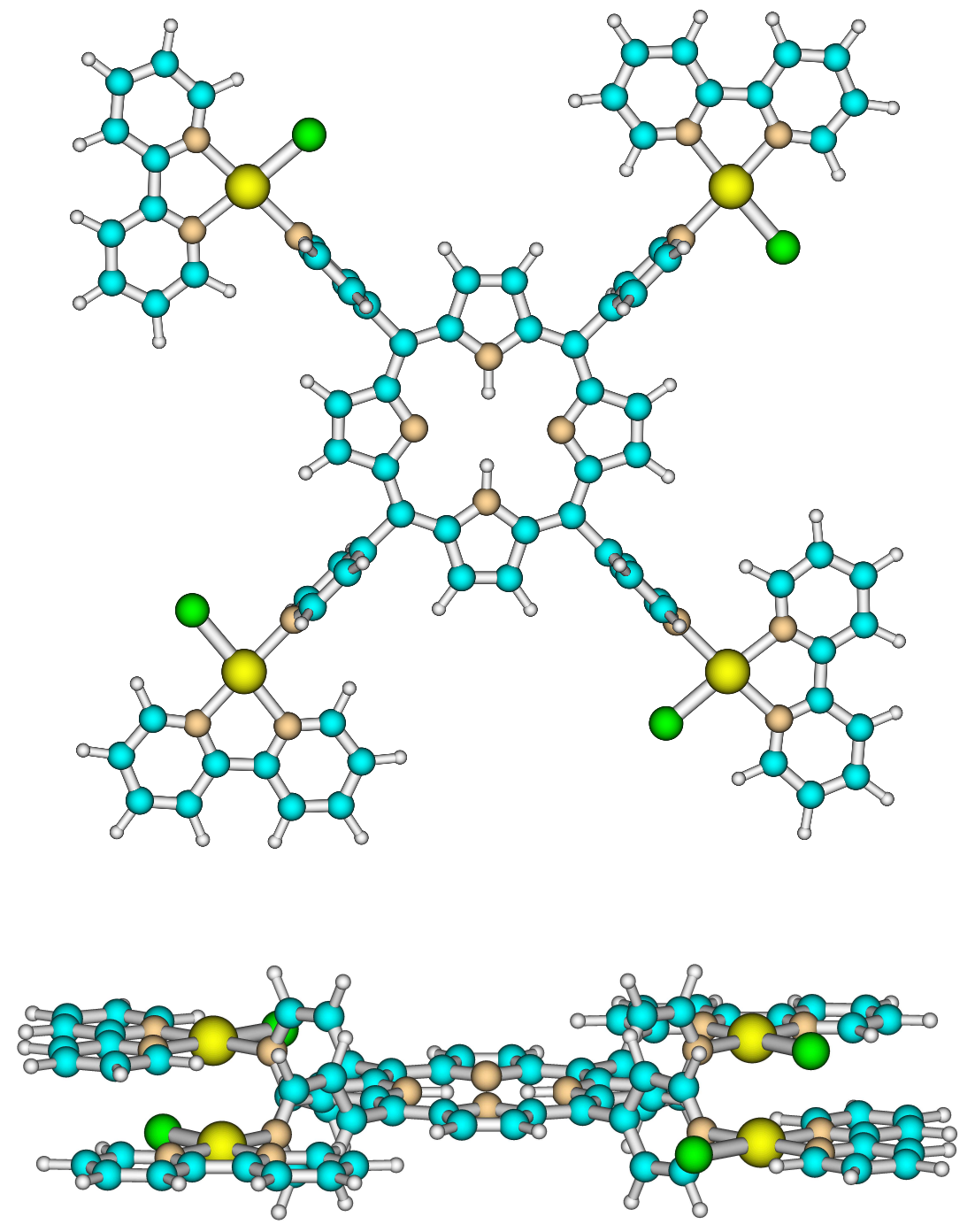

Figura 3.11: Otimização de geometria para a supermolécula 4-TPtTPyP. Projeção frontal (sup.) e lateral (inf.). Legenda dos átomos: amarelo - Pt, verde - Cl, azul - C, branco - H e laranja - N 

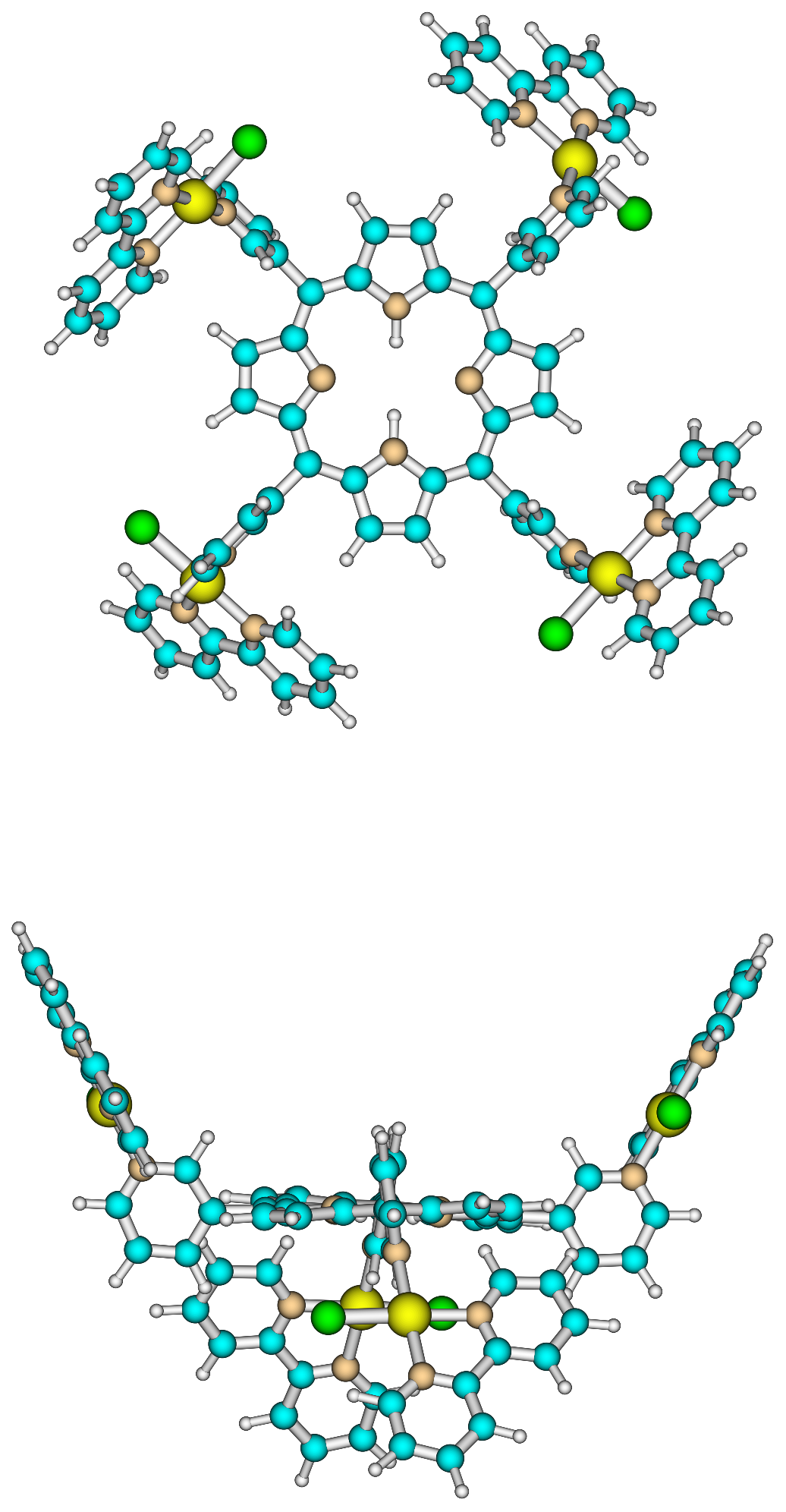

Figura 3.12: Otimização de geometria para a supermolécula 3-TPtTPyP. Projeção frontal (sup.) e lateral (inf.). Legenda dos átomos: amarelo - Pt, verde - Cl, azul - C, branco - H e laranja - N 

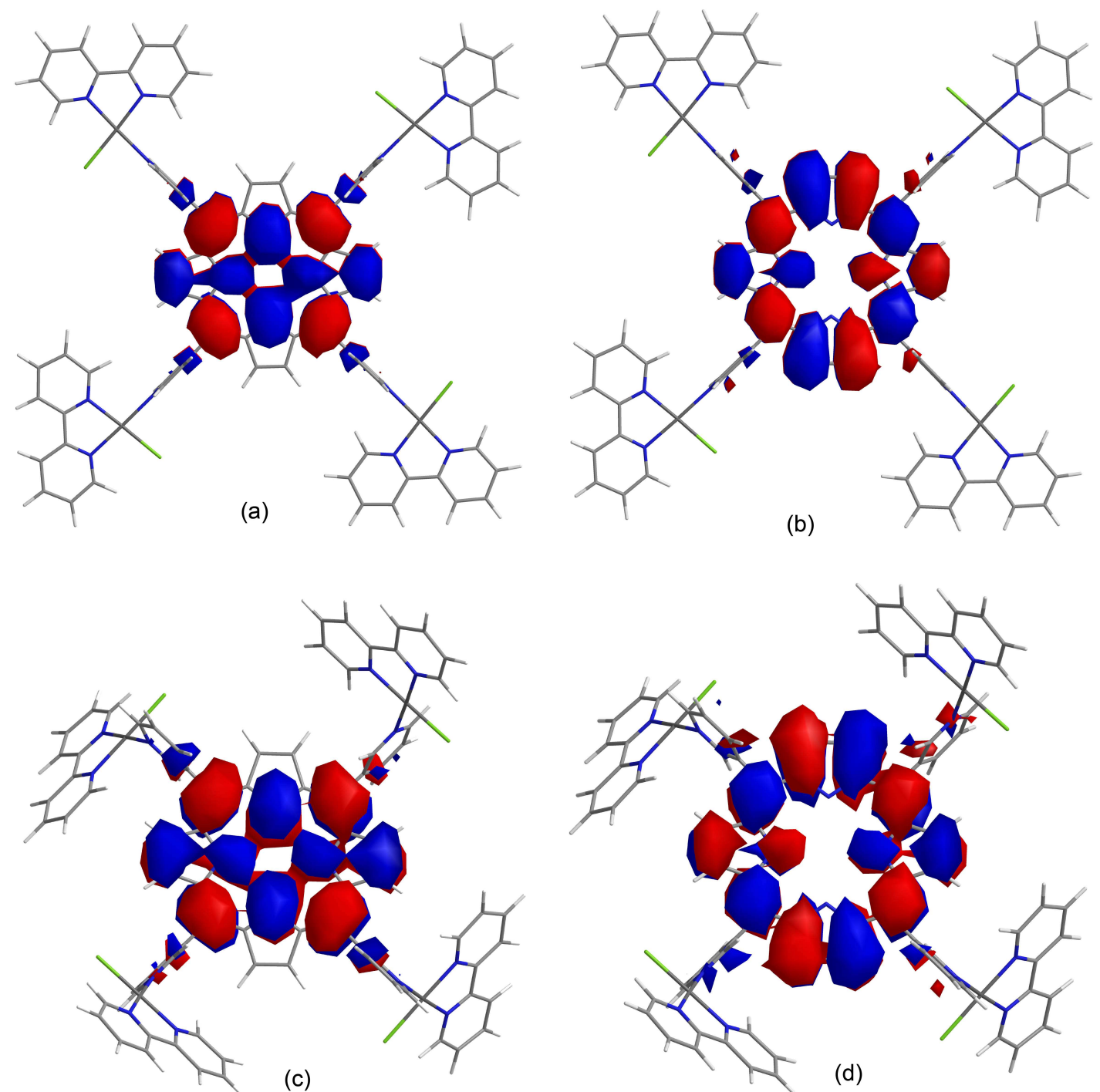

Figura 3.13: Representação dos orbitais moleculares HOMO (a) e LUMO (b) da 4-TPtTPyP e HOMO (c) e LUMO (d) da 3-TPtTPyP. 


\subsection{Espectroscopia Eletrônica}

Os processos de transição eletrônica observados nos espectros UV/VIS de porfirinas e metaloporfirinas são classicamente interpretados com base no modelo qualitativo de quatro orbitais moleculares de Gouterman et al. [67, 218,219], uma vez que todas as revisões do modelo realizadas até o momento confirmaram essas atribuições. Inclusive os cálculos moleculares realizados neste trabalho para as espécies de piridilporfirinas associadas a complexos diimínicos de platina(II) estão de acordo e corroboram esse modelo.

A espectroscopia eletrônica das porfirinas é dominada pelo sistema $\pi$ deslocalizado envolvendo 16 átomos e 18 elétrons. Todas as bandas observadas nos espectros envolvem transições $\pi-\pi^{*}$ internas do anel [67] e mesmo porfirinas substituídas como as meso-piridilporfirinas seguem o mesmo perfil eletrônico.

Nas porfirinas metaladas, os espectros se caracterizam pela presença de duas bandas entre 500 e $600 \mathrm{~nm}$, com uma separação média de $1250 \mathrm{~cm}^{-1}$ entre elas, denominadas bandas $\mathrm{Q}$. A banda $\mathrm{Q}_{(0-0)}$, de menor energia, tem origem eletrônica e a banda $Q_{(1-0)}$, de maior energia, possui um modo de excitação vibrônico acoplado a transição eletrônica. Na região de 380 a $420 \mathrm{~nm}$ observa-se a banda de maior energia do espectro, denominada banda Soret. Enquanto a banda Soret corresponde a uma transição fortemente permitida, a banda Q se refere a uma transição quasi-permitida [218,219].

Nas porfirinas base-livre, a banda $\mathrm{Q}_{(0-0)}$ se desdobra em $\mathrm{Q}_{x(0-0)}$ e $\mathrm{Q}_{y(0-0)}$ e cada uma dessas bandas tem um sobreton vibrônico $\mathrm{Q}_{x(1-0)}$ e $\mathrm{Q}_{y(1-0)}$. Considerando-se uma simetria $\mathrm{D}_{4 h}$ para o anel porfirínico, os estados excitados de menor energia são obtidos por meio da promoção de um elétron de um dos orbitais ocupados para o orbital $\mathrm{e}_{g}$, gerando dois estados de simetria $\mathrm{E}_{u}$ degenerados. A troca de um metal por dois hidrogênios no centro do anel, provoca a redução da simetria $\mathrm{D}_{4 h}$ para $\mathrm{D}_{2 d}$, quebrando a degenerescência do estado $\mathrm{E}_{u}$. Isso faz com que esse estado se desdobre em suas componentes $\mathrm{x}-\mathrm{y}$, provocando o surgimento das duas novas bandas Q explicadas acima. Esse comportamento pode ser confirmado nos espectros das supermoléculas 
4-TPtTPyP e 3-TPtTPyP base-livre e metaladas com Zn(II) discutidos nas páginas a seguir.

Segundo o modelo de quatro orbitais de fronteira de Gouterman, os orbitais HOMO possuem simetria $\mathrm{a}_{1 u}(\pi)$ e $\mathrm{a}_{2 u}(\pi)$. Já os dois orbitais LUMO são de simetria $\mathrm{e}_{g}(\pi)$. A localização desses orbitais pode ser verificada na figura 3.13 (pág. 73).

Em relação ao comportamento espectroscópico do complexo $\left[\mathrm{Pt}(\right.$ bipy $\left.) \mathrm{Cl}_{2}\right]$, verificase que ele apresenta coloração levemente amarela em DMF, MeCN e TFE. Seu espectro é dominado pela presença de duas bandas na região de 270 e 380 nm, atribuídas a transições de transferência de carga metal-ligante, MLCT, e duas bandas na região de 310 a $340 \mathrm{~nm}$, atribuídas a transições $\pi-\pi^{*}$ das bipiridinas [220-222]. Segundo dados da literatura, o orbital molecular HOMO deste complexo está centrado nos ligantes cloreto e no metal, enquanto que o orbital LUMO localiza-se predominantemente nas bipiridinas [12,221]. Apenas a título de ilustração, a figura 3.14 traz o espectro UV-VIS deste complexo em MeCN.

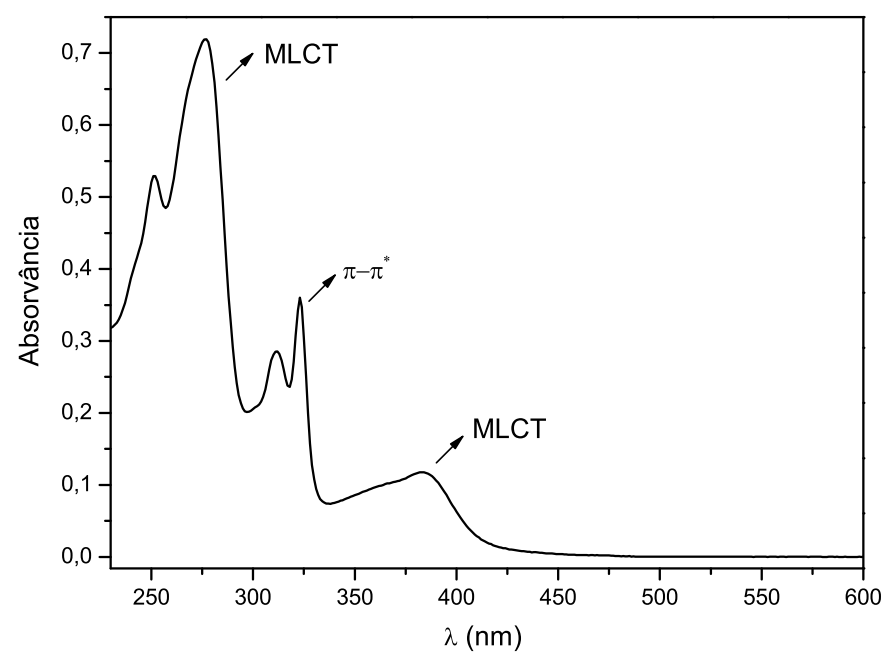

Figura 3.14: Espectro UV/VIS do complexo $\left[\mathrm{Pt}(\right.$ bipy $\left.) \mathrm{Cl}_{2}\right] 3,8 \times 10^{-6} \mathrm{~mol} \cdot \mathrm{dm}^{-3} \mathrm{em}$ $\mathrm{MeCN}$.

As supermoléculas originadas da associação deste complexo com as porfirinas 4TPyP e 3-TPyP são solúveis em TFE, DMSO, DMF e levemente em MeOH e água, 


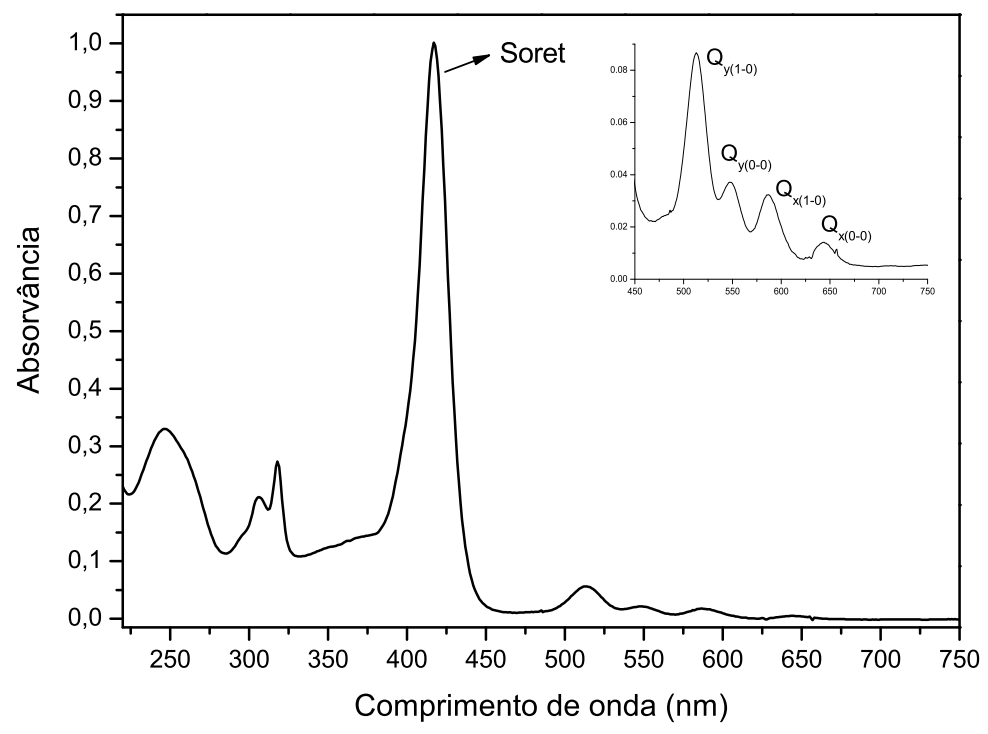

Figura 3.15: Espectro eletrônico da 4-TPtTPyP 4 x $10^{-6} \mathrm{~mol} \cdot \mathrm{dm}^{-3}$ em TFE. Inserção: bandas Q, solução 6 × $10^{-6} \mathrm{~mol} \cdot \mathrm{dm}^{-3}$.

dando origem a soluções de coloração vermelha. Entretanto, em DMSO estas espécies sofrem decomposição, com a porfirina sendo substituída pelo solvente na esfera de coordenação da platina. Este comportamento foi confirmado quando tentou-se realizar medidas de ${ }^{1} \mathrm{H}$ RMN em DMSO-D6. Através dos estudos eletroquímicos realizados em DMF (e discutidos na próximo seção), verificou-se que as supermoléculas também decompõe nesse solvente, só que mais lentamente. Já em trifluoretanol e metanol as soluções das supermoléculas preservam suas características originais por meses.

O espectro eletrônico da espécie 4-TPtTPyP, mostrado na figura 3.15, é caracterizado pela presença de bandas em 247, 307, 318, 417, 513, 548, 587 e $644 \mathrm{~nm}$. Para a 3-TPtTPyP estas bandas ocorrem a 249, 306, 318, 415, 512, 545, 585 e $640 \mathrm{~nm}$, figura 3.16. Esses espectros denotam assim a presença de dois grupos cromóforos nas supermoléculas, centrados nas porfirinas e nos grupos diimínicos de platina.

Quando comparados aos espectros das porfirinas base-livre, observa-se que a coordenação periférica dos fragmentos $[\mathrm{Pt}(\mathrm{bpy}) \mathrm{Cl}]^{+}$aos grupamentos meso-piridínicos das porfirinas promove um deslocamento para o vermelho da banda Soret, indicando 


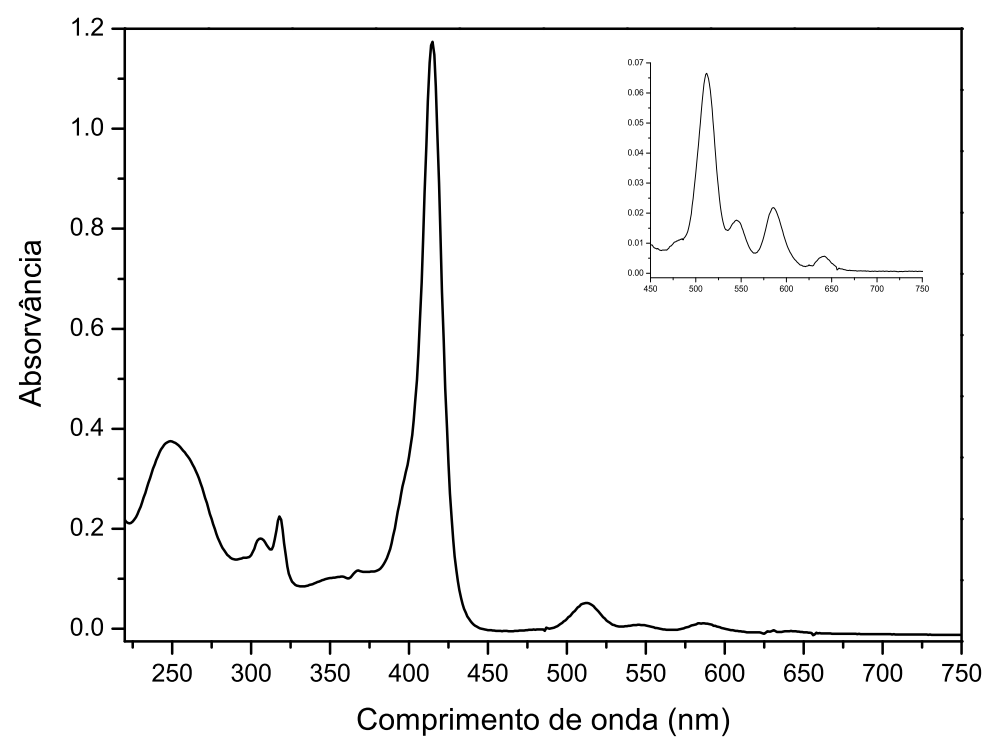

Figura 3.16: Espectro eletrônico da 3-TPtTPyP $4,5 \times 10^{-6} \mathrm{~mol} \cdot \mathrm{dm}^{-3}$ em TFE. Inserção: bandas Q, solução $6 \times 10^{-6} \mathrm{~mol} \cdot \mathrm{dm}^{-3}$.

acoplamento eletrônico entre as espécies. Pelos estudos anteriores com complexos de rutênio(II) sabe-se que esta banda é normalmente pouco afetada por coordenação exocíclica ao anel porfirínico [133,205,223], o que denota que a constante de acoplamento eletrônico para os sistemas platínicos é maior comparativamente aos sistemas com rutênio. Este perfil de deslocamento da banda Soret também foi observado para outras espécies supramoleculares envolvendo piridilporfirinas e platina(II) previamente publicadas [13].

Por outro lado, diferente do que foi verificado para os sistemas tipo quadrado moleculares de platina(II)-porfirina [13], os complexos tetracoordenados ora reportados não mostram alargamento considerável da banda Soret nem variações substanciais no valor da absortividade molar desta banda.

Em relação ao deslocamento batocrômico da banda Soret da porfirina, observase que ele é ligeiramente maior para a espécie 4-TPtTPyP, com uma variação de 8 $\mathrm{nm}$ em relação a $6 \mathrm{~nm}$ para a 3-TPtTPyP. Ou seja, a geometria espacial adota pelo isômero para prevista na modelagem molecular (figura 3.11, 71) deve favorecer uma 
maior sobreposição das funções de onda dos grupos doadores piridina e aceitadores platina, elevando a constante de acoplamento. Esses dados são tomados usando-se como referência as soluções em TFE, mas a mesma variação é observada em $\mathrm{MeOH}$, com pequenas variações na posição das bandas devido ao efeito solvatocrômico. Também em TFE e MeOH verifica-se que a espécie para é mais intensamente colorida que o isômero meta (os valores de $\log \epsilon$ para a banda $\mathrm{Q}_{y(1-0)}$ em TFE são de 4,17 para a 4-TPtTPyP e 4,07 para a 3-TPtTPyP).

Comparando-se os espectros eletrônicos das supermoléculas com o complexo precursor $\left[\mathrm{Pt}(\right.$ bipy $\left.) \mathrm{Cl}_{2}\right]$ observa-se um deslocamento para o azul de $18 \mathrm{~nm}$ da banda MLCT, situada originalmente a $265 \mathrm{~nm}$, quando este complexo é associado à porfirina 4-TPyP. Para o isômero meta essa variação é mais uma vez levemente menor, concordando com o discutido previamente. Esse comportamento é devido a substituição do ligante cloreto por uma piridina do anel porfirínico. Como o orbital HOMO do complexo $\left[\mathrm{Pt}\left(\right.\right.$ bipy $\mathrm{Cl}_{2}$ ] está centrado nos ligantes cloreto e na platina(II), a substituição de um cloreto pela meso-piridina promove um aumento na separação energética HOMO-LUMO.

\subsubsection{Espécies metaladas}

Quando soluções metanólicas de 4-TPtTPyP e 3-TPtTPyP foram tituladas com acetado de zinco(II) obteve-se as respectivas espécies metaladas 4-TPtTPyPZn e 3TPtTPyPZn. Essas novas espécies apresentam bandas a 4-TPtTPyP: 248, 310, 321, 429, 559 e $600 \mathrm{~nm}$; e 3-TPtTPyP: 249, 310, 321, 427, 558 e 598 nm, conforme apresentado nas figuras 3.17 e 3.18. As mesmas variações observadas na posição relativa das bandas entre os dois isômeros base-livre são observadas para as supermoléculas metaladas. Conforme explicado pelo modelo de Gouterman [67, 218, 219], ocorre o desaparecimento de duas bandas Q, uma vez que a elevação da simetria torna os componentes x e y indistinguíveis no estado $\mathrm{E}_{u}$ degenerado. Também conforme explicado por este modelo, a banda resultante $\mathrm{Q}_{0-0}$ é de intensidade menor que a $\mathrm{Q}_{1-0}$.

Um aspecto intrigante nestes resultados é que enquanto a intensidade da banda So- 


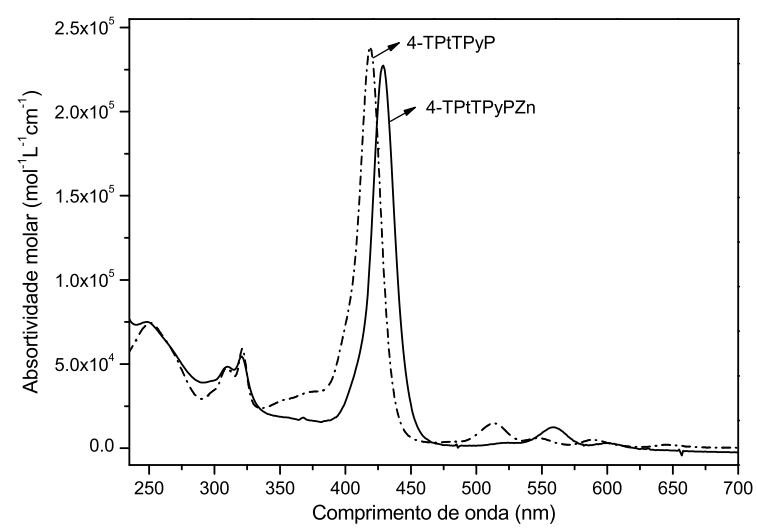

Figura 3.17: Espectro eletrônico da espécie 4-TPtTPyPZn (-) obtido da titulação de 4-TPtTPyP (- - ) com $\mathrm{Zn}\left(\mathrm{CH}_{3} \mathrm{COO}\right)_{2} 1 \times 10^{-3} \mathrm{~mol} \cdot \mathrm{dm}^{-3} \mathrm{em} \mathrm{MeOH}$.

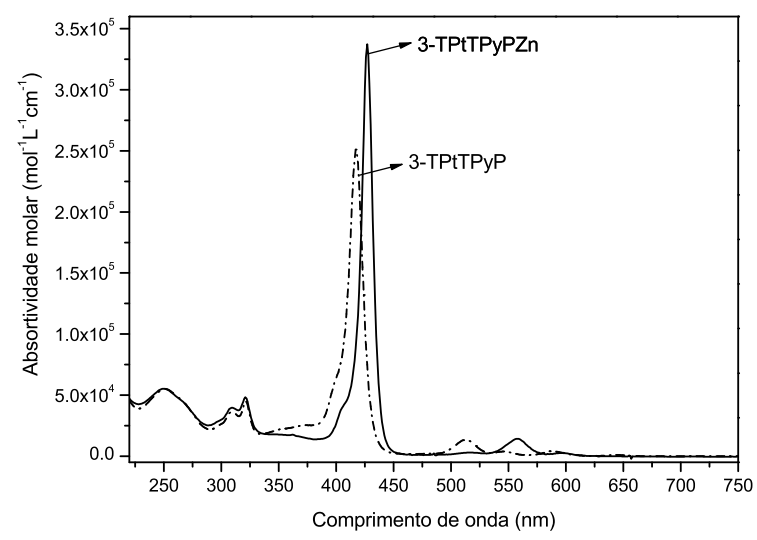

Figura 3.18: Espectro eletrônico da espécie 3-TPtTPyPZn (-) obtido da titulação de 3-TPtTPyP (- - ) com $\mathrm{Zn}\left(\mathrm{CH}_{3} \mathrm{COO}\right)_{2} 1 \times 10^{-3} \mathrm{~mol} \cdot \mathrm{dm}^{-3} \mathrm{em} \mathrm{MeOH}$.

ret do isômero para permanece praticamente inalterada na espécie metalada, o isômero meta sofre um aumento considerável na absortividade molar desta banda quando ocorre a metalação por zinco(II). A tabela 3.2 resume os dados de espectroscopia eletrônica obtidos para todas as espécies relatadas neste capítulo. 
Tabela 3.2: Dados de espectroscopia eletrônica para os compostos 4-TPyP, [Pt(bipy) $\left.\mathrm{Cl}_{2}\right]$, 4-TPtTPyP e 3-TPtTPyP.

\begin{tabular}{|c|c|c|c|c|}
\hline Composto & $\lambda(\mathrm{nm})$ & $\log \epsilon$ & Atribuição & Solvente \\
\hline 4-TPyP & 510 & 3,79 & $\mathrm{Q}_{y(1-0)}$ & TFE \\
\hline 4-ТРyP & 409 & 5,14 & Soret & TFE \\
\hline 4-ТРyP & 509 & 3,93 & $\mathrm{Q}_{y(1-0)}$ & $\mathrm{MeOH}$ \\
\hline 4-ТРyP & 412 & 5,15 & Soret & $\mathrm{MeOH}$ \\
\hline$\left[\mathrm{Pt}(\right.$ bipy $\left.) \mathrm{Cl}_{2}\right]$ & 312 & 3,87 & bpy-bpy* & $\mathrm{MeCN}$ \\
\hline$\left[\mathrm{Pt}(\right.$ bipy $\left.) \mathrm{Cl}_{2}\right]$ & 323 & 3,97 & bpy-bpy* & $\mathrm{MeCN}$ \\
\hline$\left[\mathrm{Pt}(\right.$ bipy $\left.) \mathrm{Cl}_{2}\right]$ & 382 & 3,48 & MLCT & $\mathrm{MeCN}$ \\
\hline$\left[\mathrm{Pt}(\right.$ bipy $\left.) \mathrm{Cl}_{2}\right]$ & 276 & 4,27 & MLCT & $\mathrm{MeCN}$ \\
\hline 4-TPtTPyP & 513 & 4,17 & $\mathrm{Q}_{y(1-0)}$ & TFE \\
\hline 4-TPtTPyP & 417 & 5,41 & Soret & TFE \\
\hline 4-TPtTPyP & 514 & 4,21 & $\mathrm{Q}_{y(1-0)}$ & $\mathrm{MeOH}$ \\
\hline 4-TPtTPyP & 419 & 4,39 & Soret & $\mathrm{MeOH}$ \\
\hline 4-TPtTPyPZn & 559 & 4,09 & $\mathrm{Q}_{y 1-0}$ & $\mathrm{MeOH}$ \\
\hline 4-TPtTPyPZn & 429 & 5,36 & Soret & $\mathrm{MeOH}$ \\
\hline 4-TPtTPyP & 318 & 4,85 & bpy-bpy* & TFE \\
\hline 4-TPtTPyP & 306 & 4,74 & bpy-bpy* & TFE \\
\hline 4-TPtTPyP & 247 & 4,93 & MLCT & TFE \\
\hline 3-TPtTPyP & 512 & 4,07 & $\mathrm{Q}_{y(1-0)}$ & TFE \\
\hline 3-TPtTPyP & 415 & 5,42 & Soret & TFE \\
\hline 3-TPtTPyP & 513 & 4,09 & $\mathrm{Q}_{y(1-0)}$ & $\mathrm{MeOH}$ \\
\hline 3-TPtTPyP & 417 & 5,41 & Soret & $\mathrm{MeOH}$ \\
\hline 3-TPtTPyPZn & 558 & 4,15 & $\mathrm{Q}_{y 1-0}$ & $\mathrm{MeOH}$ \\
\hline 3-TPtTPyPZn & 427 & 5,52 & Soret & $\mathrm{MeOH}$ \\
\hline 3-TPtTPyP & 318 & 4,70 & bpy-bpy* & TFE \\
\hline 3-TPtTPyP & 308 & 4,60 & bpy-bpy* & TFE \\
\hline 3-TPtTPyP & 249 & 4,92 & MLCT & TFE \\
\hline
\end{tabular}




\subsection{Eletroquímica}

Os estudos eletroquímicos foram realizados com as espécies 4-TPtTPyP e 3-TPtTPyP dissolvidas em DMF, lembrando que estes produtos foram isolados e trabalhados sempre na forma de sal tetracloreto. Todos os potenciais estão expressos vs. $\mathrm{Ag} / \mathrm{AgNO}_{3}$ $(+0,503 \mathrm{~V}$ vs. EPH $)$.

As figuras 3.19 e 3.20 mostram os voltamogramas cíclicos destas espécies na faixa de 1,0 a -2,0 V, medidos com diferentes velocidades de varredura nos sentidos anódico e catódico.

Como se pode ver por estas figuras ambas as supermoléculas demonstram um comportamento similar na região de oxidação. Observa-se nos dois casos uma onda de oxidação a $\mathrm{E}_{p a}=0,76 \mathrm{~V}$ para 4-TPtTPyP e 0,86 V para 3-TPtTPyP. Atribui-se essa onda a um processo de oxidação irreversível e monoeletrônico do anel porfirínico.

O perfil da 4-TPtTPyP na região catódica é marcada pela presença de três ondas de redução a $\mathrm{E}_{p c}=-1,24$ e $-1,38 \mathrm{~V}$ e $\mathrm{E}_{1 / 2}=-1,55 \mathrm{~V}$, sendo que a relação de corrente entre estas ondas é de aproximadamente 1:1:4, respectivamente. A primeira onda catódica com Epc $=-1,24 \mathrm{~V}$ é atribuída a redução da porfirina para espécie ânion radical $\pi \mathrm{e}$ a segunda onda com $\mathrm{E}_{p c}=-1,38 \mathrm{~V}$ é atribuída a redução da porfirina até a espécie diânionica.

Segundo a literatura o complexo $\left[\mathrm{Pt}(\right.$ bipy $\left.) \mathrm{Cl}_{2}\right]$ exibe uma onda de redução reversível a $-1,06 \mathrm{~V}$ vs $\mathrm{Ag} / \mathrm{AgCl}$ em $\mathrm{DMF}, \mathrm{NBu}_{4} \mathrm{BF}_{4}$ [221]. Assim, a onda catódica com $\mathrm{E}_{1 / 2}$ $=-1,55 \mathrm{~V}$ é atribuída a redução monoeletrônica quasi-reversível de cada uma das unidades bipy dos complexos periféricos. O perfil das reduções não sofre alteração com a velocidade ou o sentido de varredura, conforme ilustrado na figura 3.19.

Em $\mathrm{E}_{p c}=-0,41 \mathrm{~V}$ aparece uma onda de redução desconhecida, a qual pode estar acoplada a algum processo de redução ou resultar de processos vinculados a impurezas do solvente. Isto porque quando se diminui a janela de potencial para 0,6 a -1,2 V essa onda desaparece, conforme ilustrado na figura 3.21.

Por outro lado, quando a janela de potencial é expandida para regiões mais negati- 

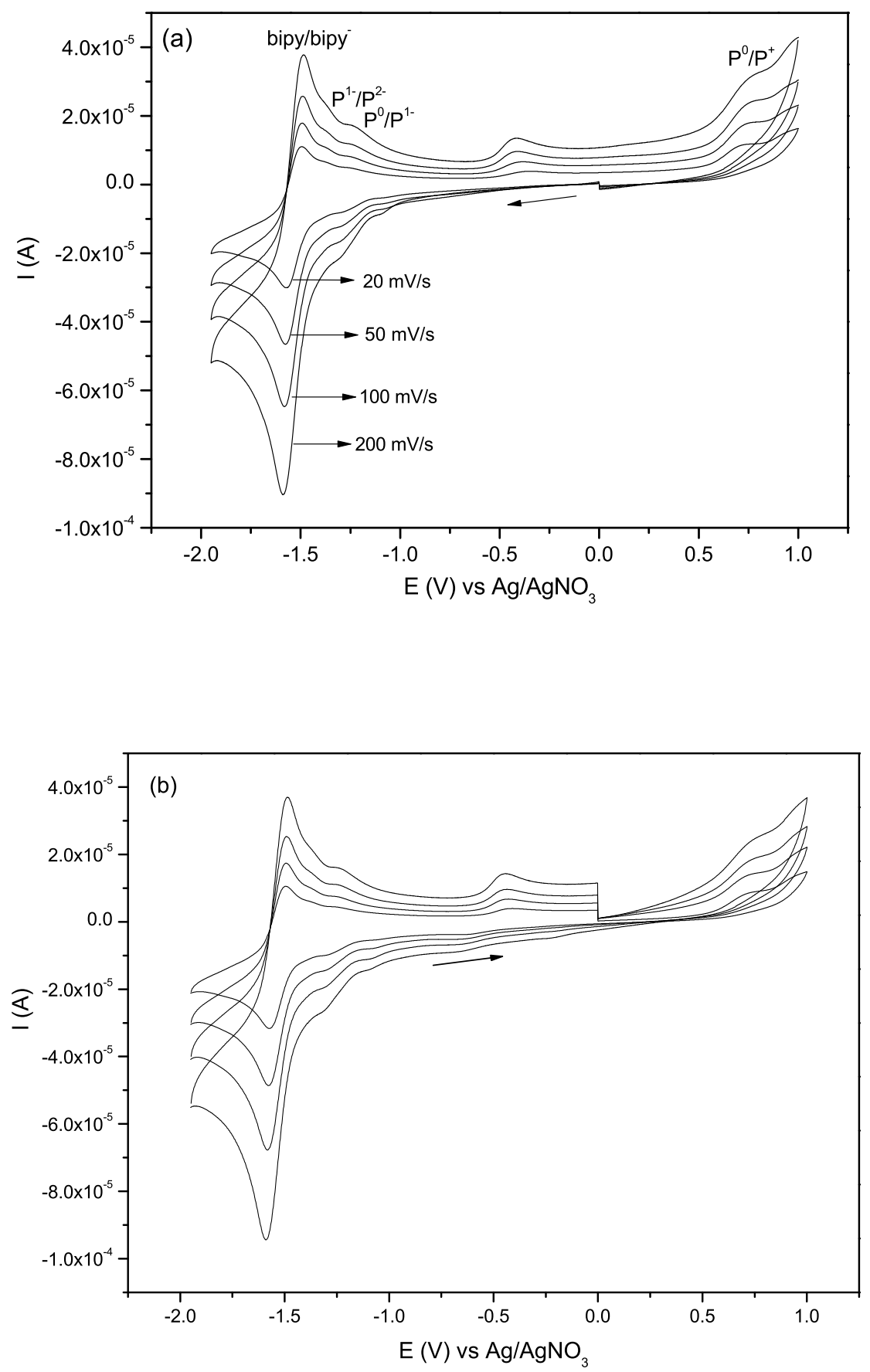

Figura 3.19: Voltamogramas cíclicos da 4-TPtTPyP medidos a 20, 50, 100 e 200 $\mathrm{mV} / \mathrm{s}$. (a) Varredura no sentido catódico e (b) Varredura no sentido anódico. Solução 0,5mM em DMF-TEAClO ${ }_{4}$ 0,1M. Eletrodo de platina 

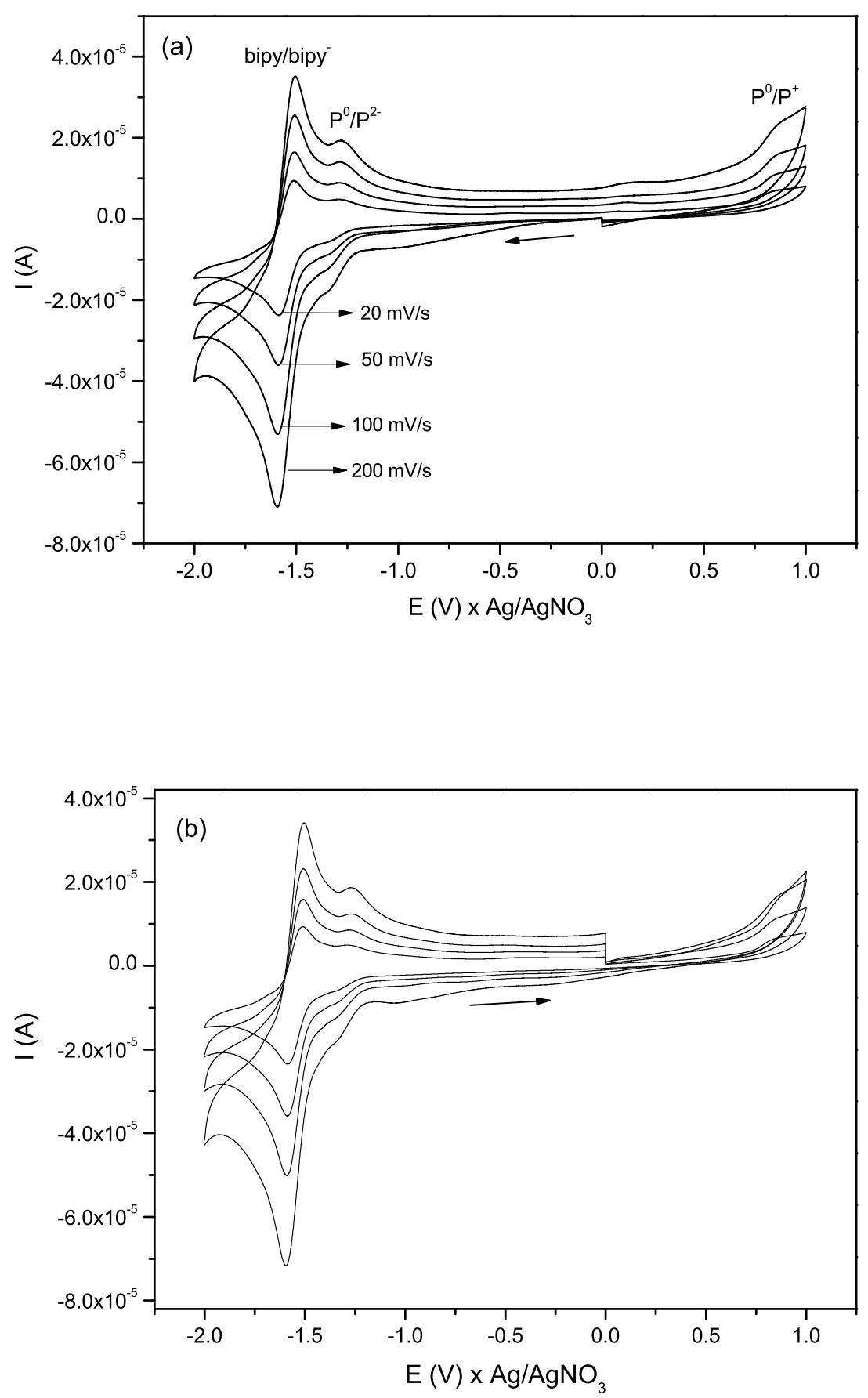

Figura 3.20: Voltamogramas cíclicos da 3-TPtTPyP medidos a 20, 50, 100 e 200 $\mathrm{mV} / \mathrm{s}$. (a) Varredura no sentido catódico e (b) Varredura no sentido anódico. Solução 0,5mM em DMF-TEAClO 4 0,1M. Eletrodo de platina. 

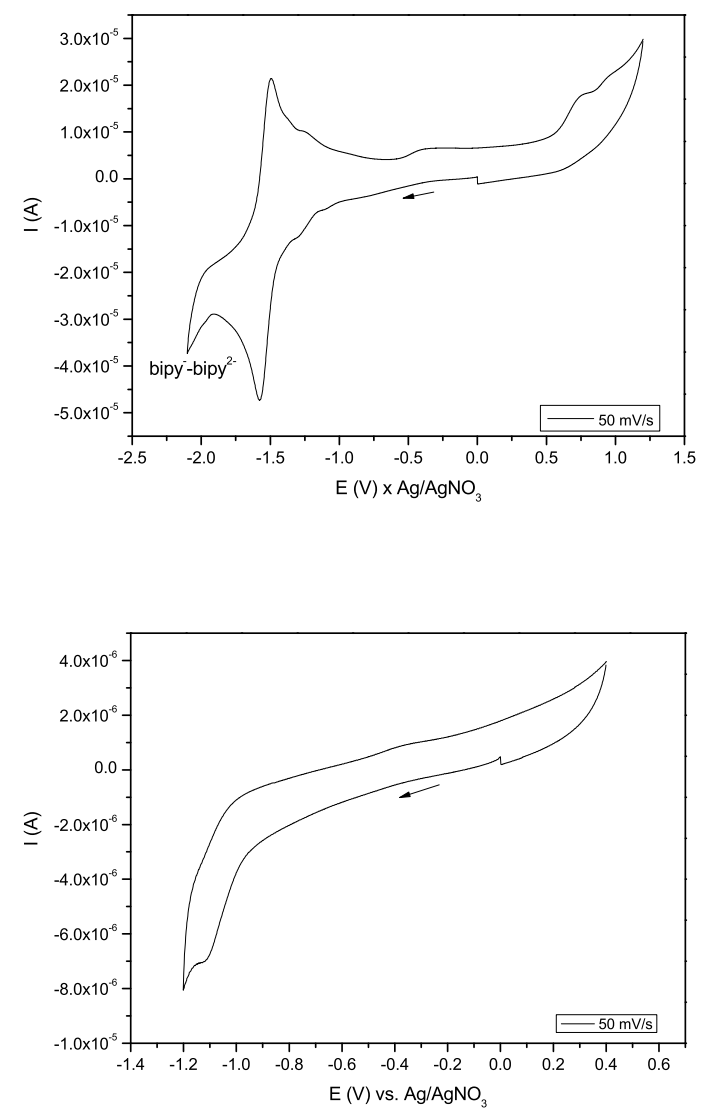

Figura 3.21: Voltamogramas cíclicos a $50 \mathrm{mV} / \mathrm{s}$ com diferentes janelas de potencial de uma solução 0,5 mM de 4-TPtTPyP em DMF-TEAClO 4 0,1M, eletrodo de platina. Varredura no sentido catódico.

vas, cruzando-se a faixa de -2,0 V , tem-se acesso a segunda onda de redução das bipiridinas, a qual corresponde a um processo irreversível com $\mathrm{E}_{p c}=-2,1 \mathrm{~V}$, figura 3.21. Essa segunda redução também é observada para complexos tipo Pt(bipy)L $\mathrm{L}_{2}[220,222,224]$.

Diferente da 4-TPtTPyP, os voltamogramas cíclicos da 3-TPtTPyPsão dominados pela presença de apenas duas ondas de redução a $\mathrm{E}_{p c}=-1,30 \mathrm{~V}$ e $\mathrm{E}_{1 / 2}=-1,54 \mathrm{~V}$. Como a relação de corrente entre essas duas ondas é de aproximadamente 1:2, acredita-se que a onda a -1,30 V esteja vinculada a um processo de redução de dois elétrons da porfirina, formando a espécie diânionica. Mesmo a velocidades de varredura mais baixas não se verifica a separação desta redução em duas ondas independentes como acontece no isômero para. De maneira análoga a 4-TPtTPyP, a onda com $\mathrm{E}_{1 / 2}=-1,54 \mathrm{~V}$ é 
atribuída a redução quase-reversível e monoeletrônica das bipiridinas. Em ambos os casos nenhum processo centrado no metal é observado. Devido a baixa solubilidade das porfirinas 3-TPyP e 4-TPyP em solventes de uso comum na voltametria cíclica não foi possível realizar estudos comparativos com as supermoléculas.

Como conclusão, o que se observa nos estudos eletroquímicos desta classe de complexos supermoleculares de platina(II), é que, em geral, os processos redox realizado pelos componentes moleculares isolados são mantidos na estrutura supramolecular, com a ocorrência de apenas pequenas variações no potencial. Ou seja, essas espécies costumam exibir respostas de corrente intensificada, mas com o mesmo perfil obtido para os componentes livres. Esse perfil coincide com o verificado para complexos porfirínicos supermoleculares de rutênio(II, III) [133, 223, 225, 226] e outros sistemas de natureza supramolecular reportados na literatura [40].

\subsubsection{Ensaio de eletrocatálise}

Em função da conhecida atividade eletrocatalítica dos complexos de rutênio(II)tetrapiridilporfirinas previamente estudados, e da importância desta atividade para fins de aplicação destes sistemas como sensores eletroquímicos, realizamos um teste empregando eletrodo de carbono vítreo modificado com o filme da espécie 4-TPtTPyP. Como já é sabido que os melhores resultados são obtidos em meio ácido [99, 133], empregamos solução tampão acetato com pH 4,7.

O que de certa forma era esperado, verificou-se que essa porfirina tetraplatinada não apresenta atividade eletrocatalítica de oxidação de nitrito. Em todo caso, este resultado prova que a atividade das espécies tetrarutenadas está centrada nos processos redox dos complexos de rutênio associados à porfirina. Como neste caso tem-se um centro metálico redox inerte, a variação da corrente do processo anódico apresenta dependência linear com a concentração de nitrito. Ou seja, a presença do filme não provoca intensificação da resposta.

Porém, é verificada uma curiosa onda de redução eletrocatalítica quando o eletrodo 
de carbono vítreo é recoberto com o filme de 4-TPtTPyP. Veja para isto a figura 3.22 onde é mostrado o voltamograma cíclico obtido antes e após a modificação do eletrodo. Os voltamogramas cíclicos varridos com diferentes concentrações de nitrito no meio e a relação corrente x potencial observada para as regiões de oxidação e redução são mostradas na figura 3.23. Esses resultados mostram que a redução da supermolécula gera um sítio cataliticamente ativo para a redução do íon nitrito, provavelmente centrado no anel porfirínico.

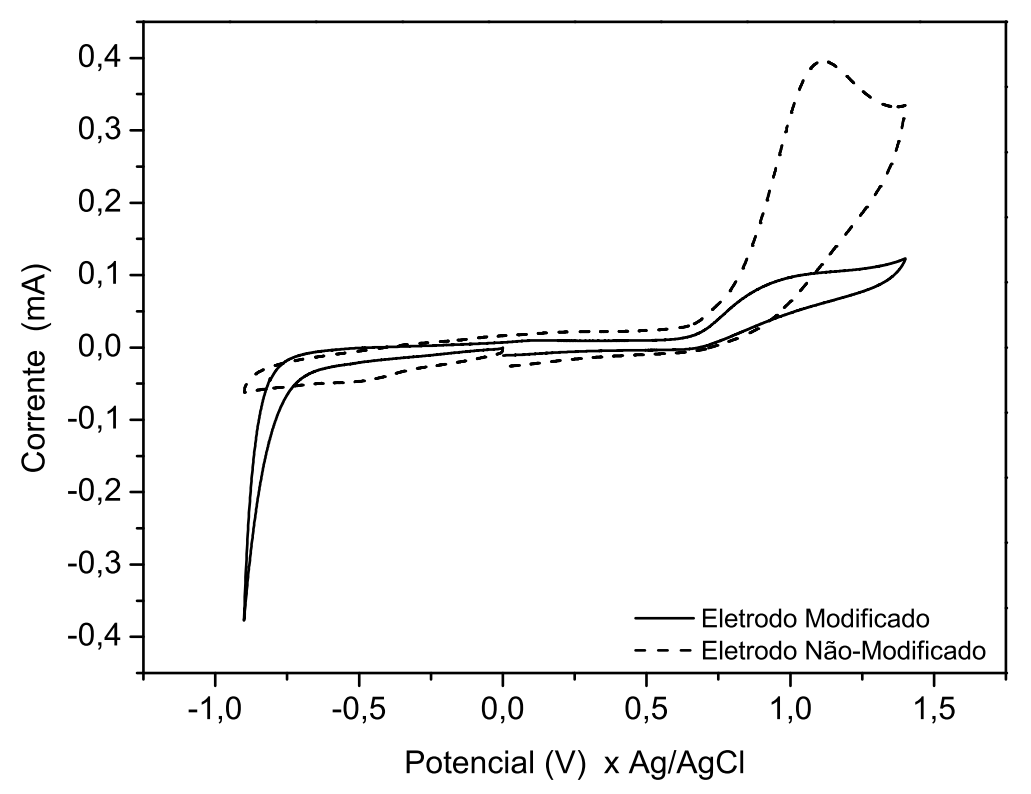

Figura 3.22: Voltamogramas cíclicos de uma solução tampão acetato contendo $5,2 \times 10^{-3} \mathrm{mmol} \cdot \mathrm{dm}^{-3}$ de $\mathrm{NO}_{2}^{-}$. Eletrodo de carbono vítreo modificado com filme de 4-TPtTPyP (-) e não modificado (---·). 

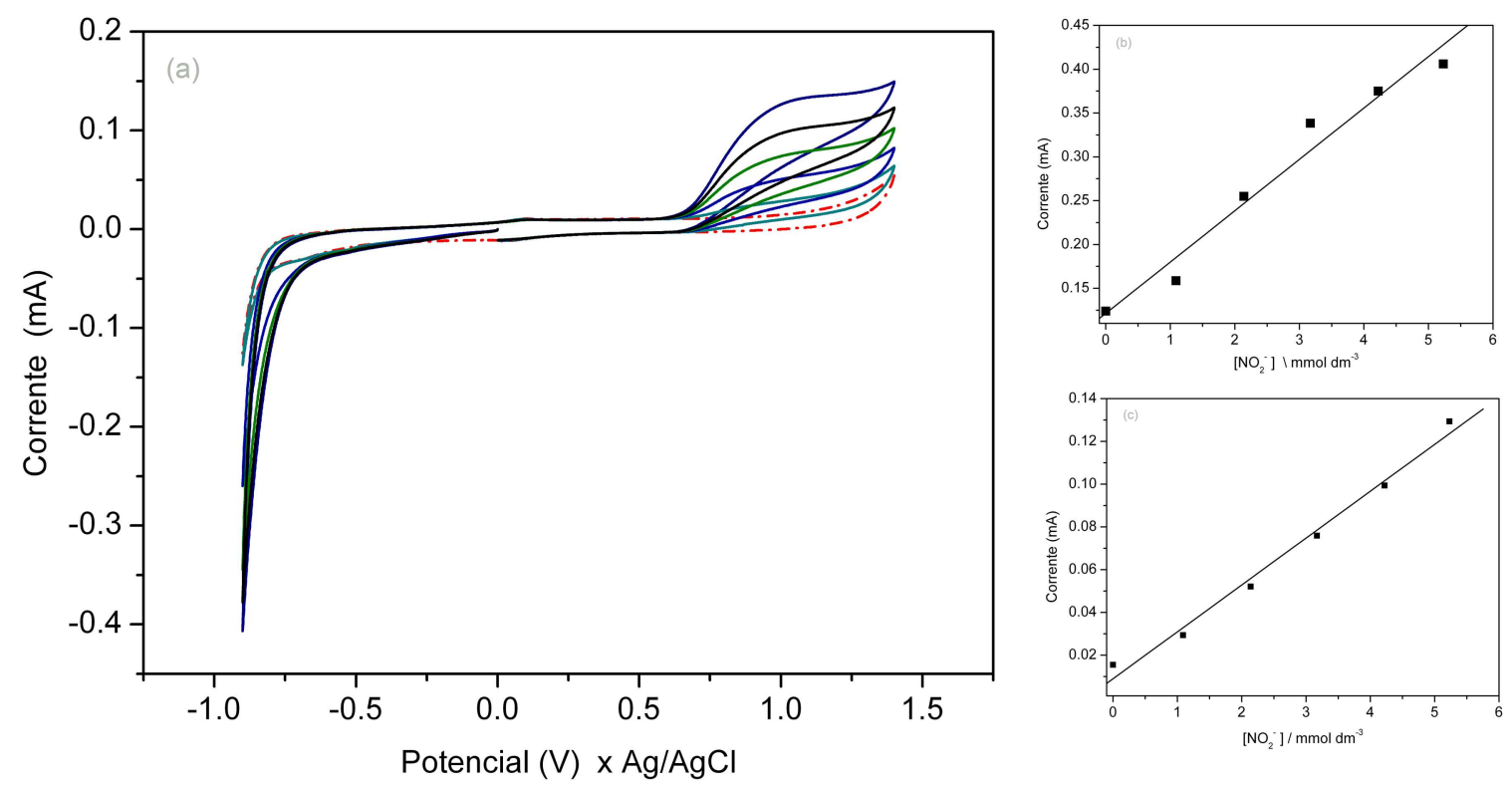

Figura 3.23: Eletrodo de carbono vítreo modificado com filme de 4-TPtTPyP. a) Voltamogramas cíclicos em solução tampão acetato, $\mathrm{pH}=4,7$, contendo 0 a $5,2 \times 10^{-3}$ $\mathrm{mmol} \cdot \mathrm{dm}^{-3}$ de $\mathrm{NO}_{2}^{-}$. (b) Relação i x $\left[\mathrm{NO}_{2}^{-}\right]$para a região de redução e (c) Relação i x $\left[\mathrm{NO}_{2}^{-}\right]$para a região de oxidação. 


\subsection{Espectroeletroquímica}

A espectroeletroquímica é uma técnica extremamente útil para atribuição dos processos observados por voltametria cíclica. Por esse motivo ela tem sido largamente empregada no estudo de complexos polinucleares de porfirinas [58, 133, 223, 225, 226].

Neste trabalho as investigações espectroeletroquímicas foram realizados na faixa de $-2,0$ a 1,0 V em DMF em ambos os casos. Como parte dos processos observados pela voltametria cíclica são não reversíveis tanto para a 4-TPtTPyPcomo para a 3TPtTPyP, optou-se pelo método de se acompanhar a variação do espectro eletrônico a um dado potencial fixo.

Vale lembrar que os espectros eletrônicos destas novas estruturas são caracterizados pela presença de bandas em 247, 307, 318, 417, 513, 548, 587 e 644 nm para a 4TPtTPyP e em valores próximos para a 3-TPtTPyP. Essas bandas correspondem por sua vez a transições internas $\pi-\pi^{*}$ dos ligantes bipiridina (307 e $\left.318 \mathrm{~nm}\right)$, transição MLCT do cromóforo $[\mathrm{Pt}(\text { bipy }) \mathrm{Cl}]^{+}(247 \mathrm{~nm})$, a banda Soret da porfirina $(417 \mathrm{~nm})$ e as quatro bandas $\mathrm{Q}_{y(1-0)}(513 \mathrm{~nm}), \mathrm{Q}_{y(0-0)}(548 \mathrm{~nm}), \mathrm{Q}_{x(1-0)}(587 \mathrm{~nm})$ e $\mathrm{Q}_{x(0-0)}(644$ $\mathrm{nm})$.

Nos voltamogramas cíclicos da 4-TPtTPyP são observadas três ondas de redução e uma onda de oxidação. Já nos VCs da 3-TPtTPyP obteve-se duas ondas de redução e uma onda de oxidação.

Conforme ilustrado na figura 3.24, na região de oxidação observou-se diminuição na intensidade da banda Soret da porfirina quando aplicou-se um potencial de 1,0 V. Uma diminuição menos perceptível é verificada também na banda $\mathrm{Q}_{y(1-0)}$. Os resultados foram similares para os dois isômeros e ratificam a proposta feita na voltametria cíclica de que a onda de oxidação observada é um processo centrado na porfirina.

Para a 4-TPtTPyP verifica-se o desaparecimento gradual da banda Soret acompanhada pelo surgimento de uma nova banda a $\approx 448 \mathrm{~nm}$ quando aplica-se um potencial de -1,35 V. Essa variação espectral pode ser visualizada na figura 3.25. Nessa mesma figura observa-se que quando é aplicado um potencial de -1,45 V ocorre intensificação 

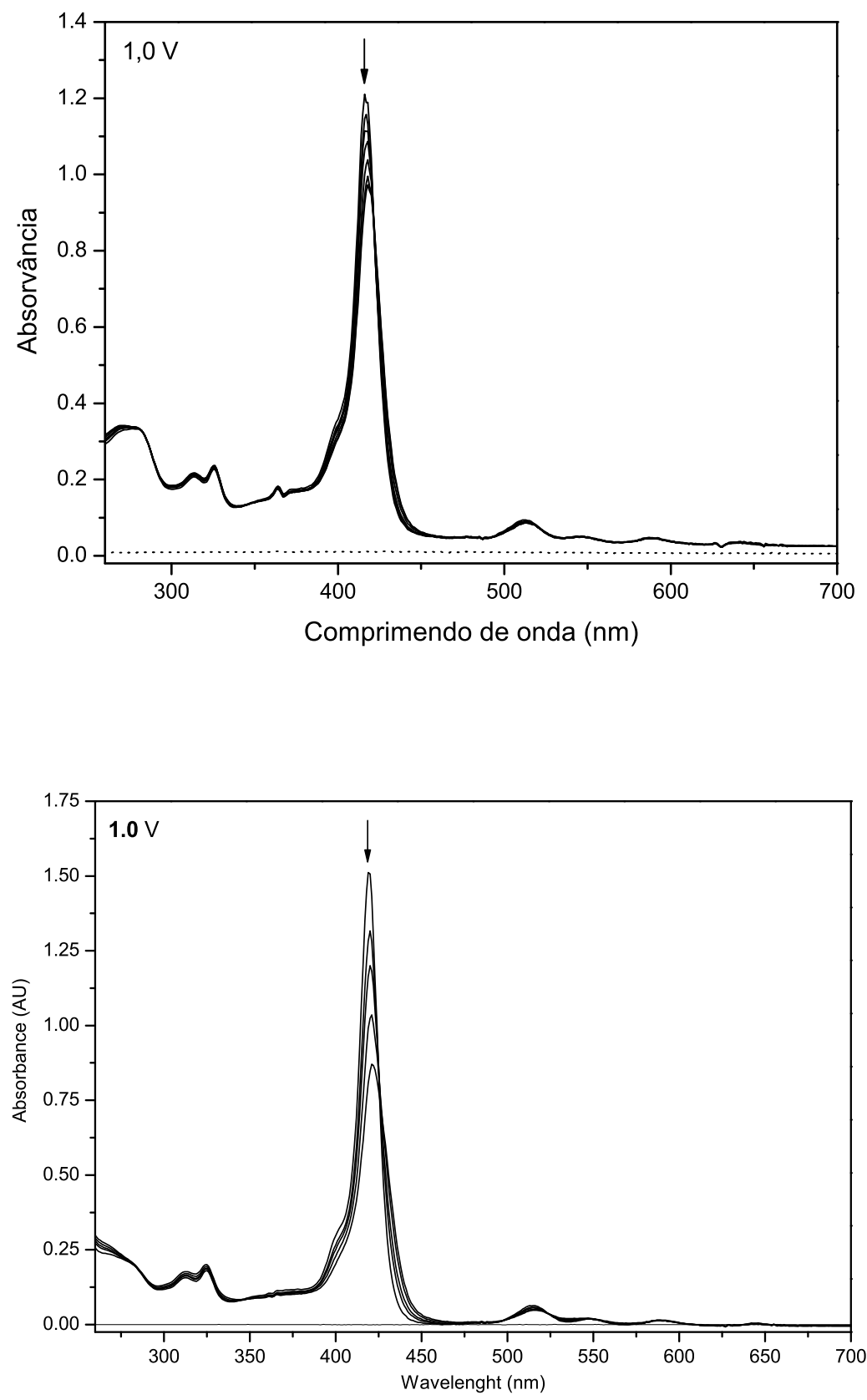

Figura 3.24: Espectroeletroquímica na região de oxidação das supermoléculas 4TPtTPyP e 3-TPtTPyP. Soluções $1 \times 10^{-4} \mathrm{~mol} \cdot \mathrm{dm}^{-3}$ em DMF, TEAClO . Potencial aplicado $=1 \mathrm{~V}$. 
da banda a $\approx 448 \mathrm{~nm}$. Essa nova banda está vinculada a formação da porfirina diânionica e nenhuma alteração é provocada nas bandas associadas aos complexos periféricos de platina nessas duas faixas de potencial.

Porém, quando é empregado um potencial de $-1,75 \mathrm{~V}$ os processos de redução das bipiridinas tornam-se acessíveis, e além do completo desaparecimento da banda Soret original, observa-se eliminação das bandas bipy-bipy* a 307 e 318 nm, acompanhadas da formação de uma banda a $\approx 358 \mathrm{~nm}$, associada a formação da espécie bipy aniônica. Verifica-se ainda o surgimento de uma banda a $492 \mathrm{~nm}$ nesse potencial.

Apesar do isômero meta 3-TPtTPyP ter apresentado somente uma onda de redução vinculada ao anel porfirínico, na espectroeletroquímica é possível distinguir dois processos de redução vinculadas a porfirina. A figura 3.26 mostra a evolução dos espectros UV/VIS obtida com a aplicação de potencias de -1,30 e -1,70 V.

De maneira similar ao relatado para a 4-TPtTPyP observa-se uma eliminação gradual das bandas Soret, $\mathrm{Q}_{y(1-0)}$ e bipy-bipy* acompanhadas da formação de novas bandas a 440 e $\approx 491 \mathrm{~nm}$ nos espectros sucessivos obtidos nestes dois potenciais.

Quando são aplicados potenciais acima de -1,8 V ocorre decomposição da supermolécula e pela aplicação de potencias positivos novamente, observa-se uma regeneração apenas parcial do espectro original. Neste caso deve ocorrer processos de transferência de elétrons com o solvente, reação com impurezas ou até mesmo reações de substituição na esfera de coordenação da platina(II). Essas medidas foram realizadas em triplicata para ambos isômeros, usando-se sempre $\mathrm{DMF}$ e $\mathrm{TEAClO}_{4}$ como eletrólito de suporte, percebendo-se que o solvente tem um efeito considerável sobre a reversibilidade e a clara visualização dos processos. 

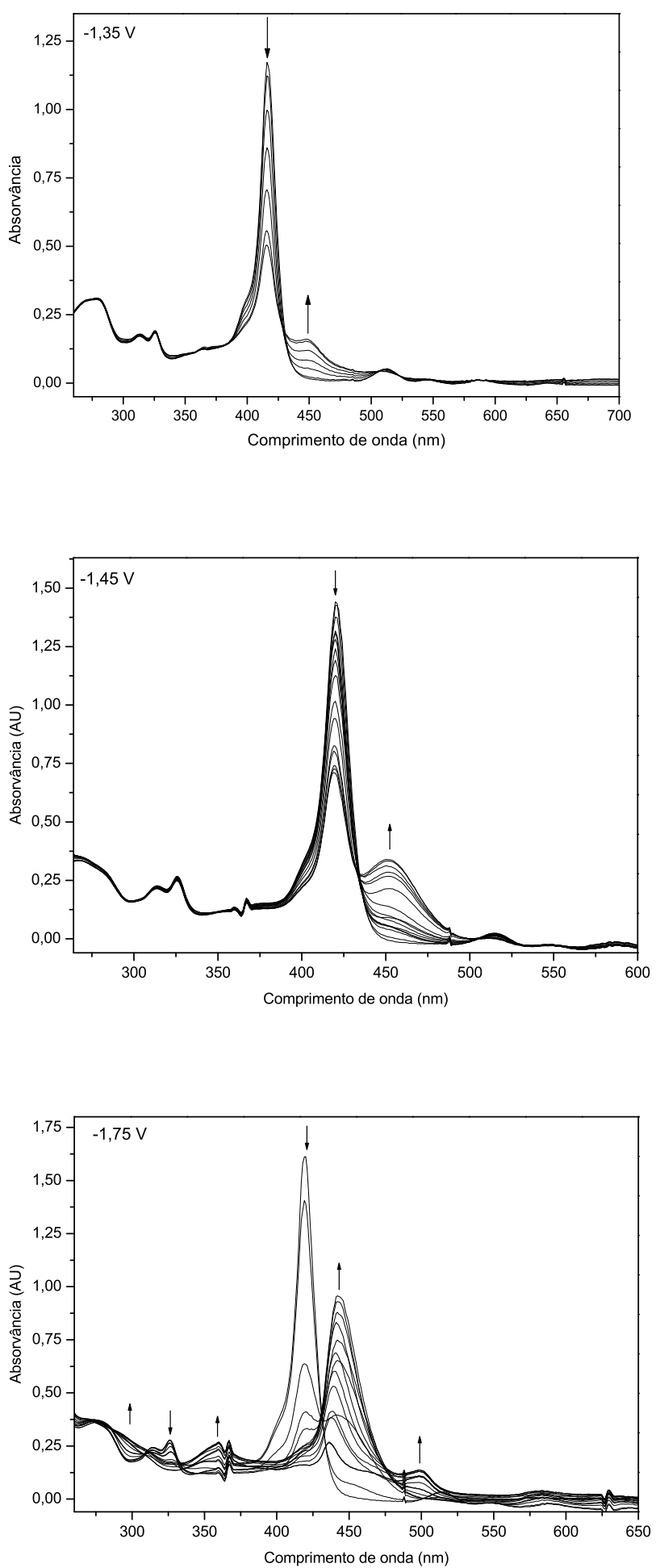

Figura 3.25: Espectroeletroquímica na região de redução da 4-TPtTPyP. Solução $1 \mathrm{x} 10^{-4} \mathrm{~mol} \cdot \mathrm{dm}^{-3} \mathrm{em} \mathrm{DMF}, \mathrm{TEAClO}_{4}$. Espectros sucessivos obtidos com potenciais de $-1,35,-1,45 \mathrm{~V},-1,75 \mathrm{~V}$. 

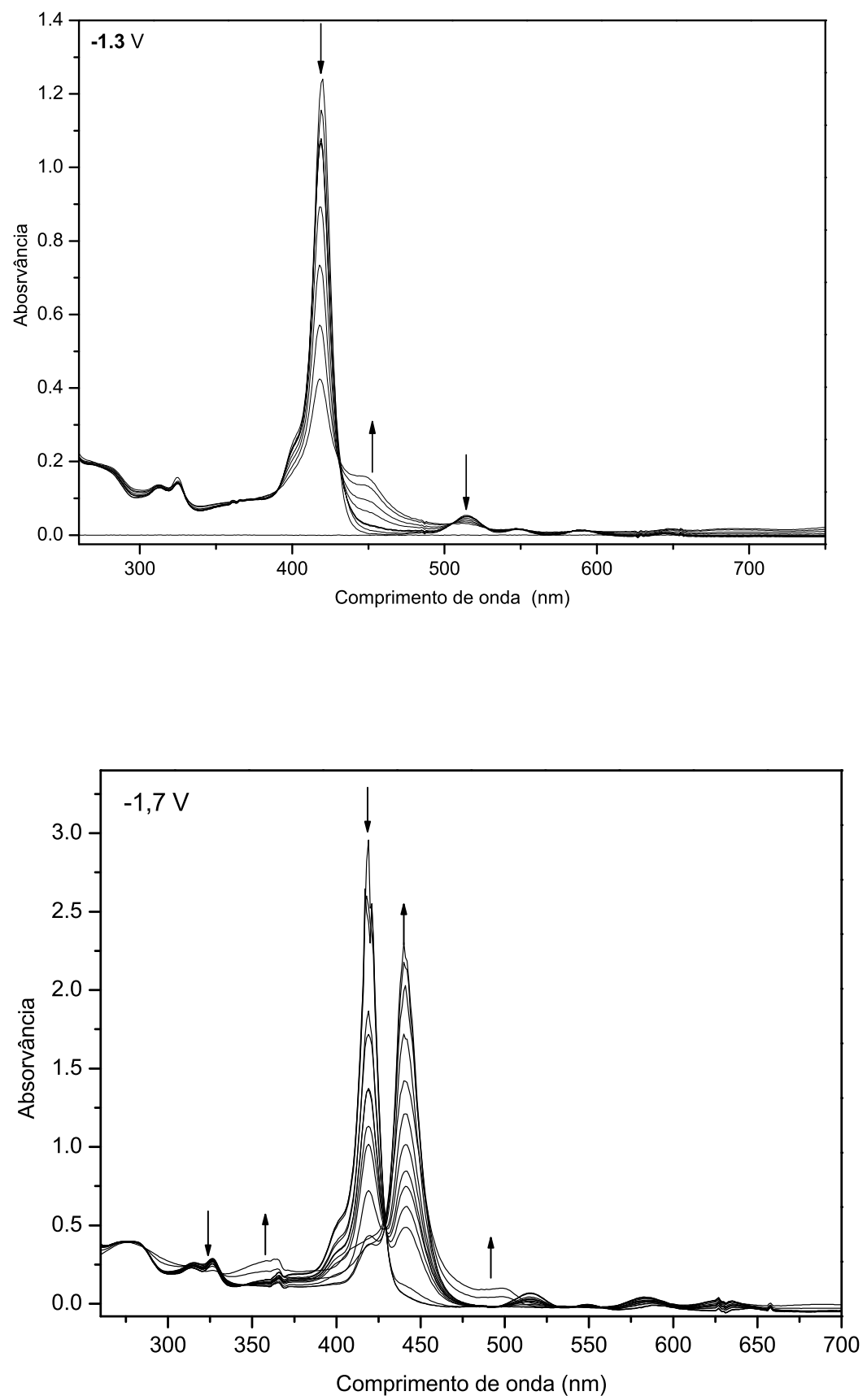

Figura 3.26: Espectroeletroquímica na região de redução da 3-TPtTPyP. Solução $1 \times 10^{-4} \mathrm{~mol} \cdot \mathrm{dm}^{-3}$ em DMF, TEAClO 4 . Espectros sucessivos obtidos com potenciais de $-1,30$ e $-1,70 \mathrm{~V}$. 


\subsection{Estudos de Interação com DNA}

\subsubsection{Titulações Espectrofotométricas}

Os estudos preliminares de interação com DNA foram realizados pela titulação espectrofotométrica de soluções das supermoléculas diluídas em meio tamponado, contendo uma pequena quantidade de TFE para melhorar a solubilidade dos complexos no meio. Como o TFE é um solvente polar compatível com membranas e biomoléculas, ele pôde ser usado sem causar interferência nos resultados. Todas as titulações foram realizadas pela adição da solução de DNA sobre as supermoléculas. A ocorrência ou não de interações é observada pela variação na absortividade molar das bandas das supermoléculas, levando-se em conta o efeito da diluição, o qual é minimizado pelo uso de soluções com pelo menos uma ordem de grandeza de diferença nas concentrações relativas das soluções.

É possível também se calcular a constante de interação a partir dos dados da titulação. Porém, como a ressonância plasmônica de superfície é uma técnica muito mais robusta para fornecer valores de constantes, as titulações espectrofotométricas foram empregadas como uma análise qualitativa.

Quando a 4-TPtTPyP foi titulada com CT-DNA observou-se a formação de um precipitado no meio e essa precipitação acontece mesmo quando emprega-se soluções tampão contendo 3, 10 e 20\% de TFE. Estes resultados estão ilustrados na figura 3.27.

A auto-agregação é um fenômeno típico de porfirinas e macrociclos correlatos como as ftalocianinas. Para averiguar-se se essa precipitação não era um efeito do meio aquoso tamponado, além de variar a quantidade de TFE na solução tampão, preparouse soluções desta supermolécula em diferentes meios. Como pode ser visto na figura 3.28, ocorre alargamento da banda Soret e um forte decréscimo na absortividade molar desta banda nas diferentes soluções, donde infere-se que ocorre uma forte agregação em meio aquoso e principalmente meio aquoso tamponado. Entretanto, nenhum precipitado é formado. 


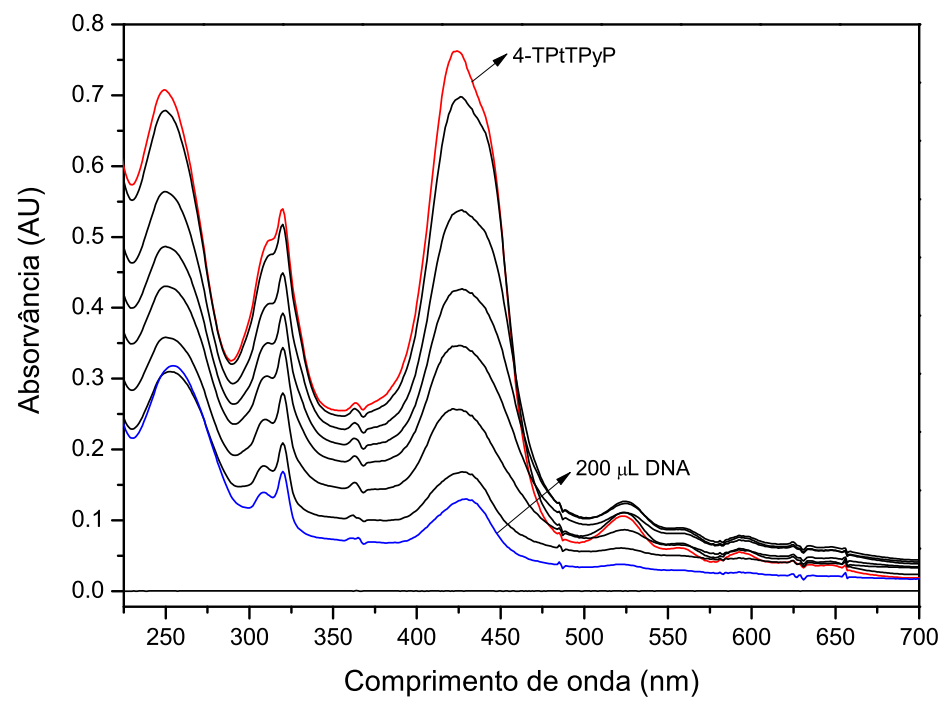

Figura 3.27: Titulação espectrofotométrica da 4-TPtTPyP $1,6 \times 10^{-5} \mathrm{~mol} \cdot \mathrm{dm}^{-3} \mathrm{em}$ tampão Tris-HCl com 10\% TFE. Adição de alíquotas de 10, 20, 30, 40, 60, 120 e $200 \mu \mathrm{L}$ de DNA $2,2 \times 10^{-4} \mathrm{~mol} \cdot \mathrm{dm}^{-3}$.

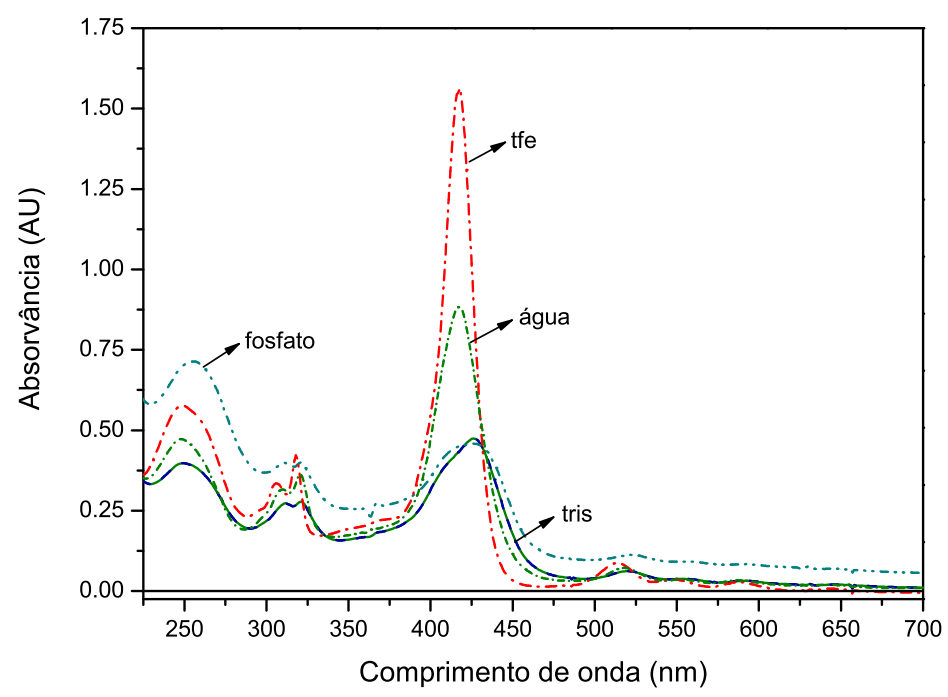

Figura 3.28: Solução de 4-TPtTPyP $8,2 \times 10-6 \mathrm{~mol} \cdot \mathrm{dm}^{-3}$ preparada em: TFE, água, tampão tris- $\mathrm{HCl}(\mathrm{pH} \mathrm{7,4)} \mathrm{e} \mathrm{tampão} \mathrm{fosfato}(\mathrm{pH} 6,9)$. 
Ao invés de ocorrer metalointecarcalção no DNA, acredita-se que a geometria planar desta espécie leve a um modo de ligação externa, com as unidades catiônicas distribuindo-se em torno dos filamentos duplamente entrelaçados da cadeia deste biopolímero. Ou seja, esta supermolécula deve possuir um padrão de interação essencialmente eletrostático, levando a formação de grandes agregados supramoleculares que precipitam em solução.

Os resultados da titulação do isômero meta com CT-DNA são mostrados na figura 3.29. As alíquotas de DNA foram adicionadas à solução de 3-TPtTPyP até que não observou-se maiores variações no espectro eletrônico da supermolécula e neste caso não se observou a formação de precipitado.

A adição de DNA à solução de 3-TPtTPyP promove diminuição na absortividade molar das bandas Soret da porfirina e $\pi-\pi^{*}$ das bipiridinas, seguidas de um leve aumento na intensidade da banda MLCT a $250 \mathrm{~nm}$. A variação nas propriedades eletrônicas das duas unidades cromóforas que constituem essa supermolécula, indicam que há uma interação considerável entre a 3-TPtTPyP e a cadeia de DNA.

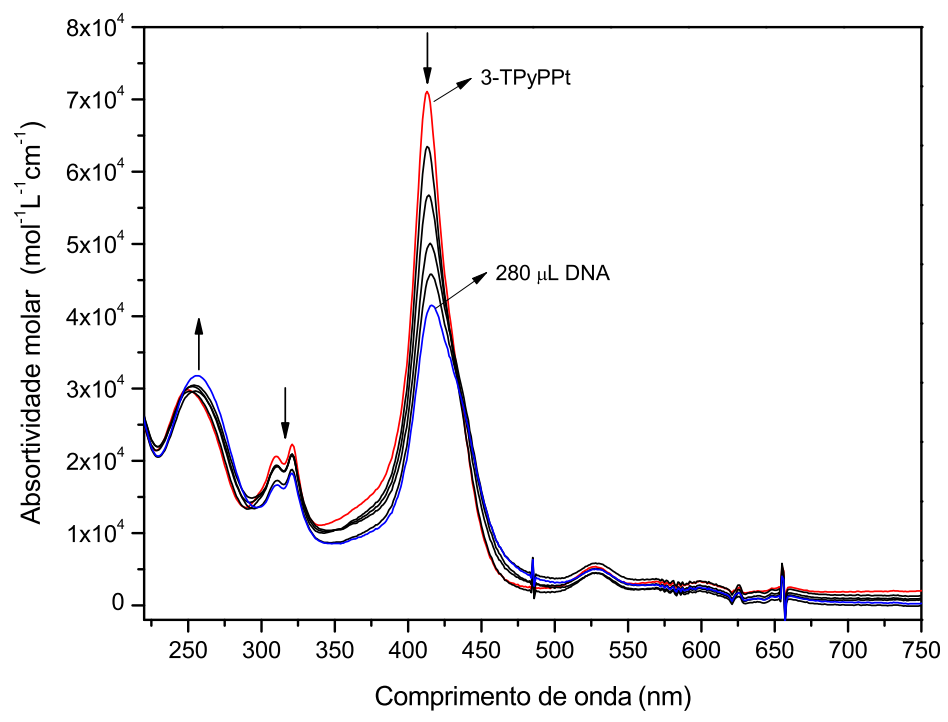

Figura 3.29: Titulação espectrofotométrica da 3-TPtTPyP $1,6 \times 10^{-5} \mathrm{~mol} \cdot \mathrm{dm}^{-3} \mathrm{em}$ tampão Tris- $\mathrm{HCl}$ com 10\% TFE. Adição de alíquotas de 20, 40, 80, 120 e $280 \mu \mathrm{L}$ de DNA $8,7 \times 10^{-5} \mathrm{~mol} \cdot \mathrm{dm}^{-3}$. 


\subsubsection{Ressonância Plasmônica de Superfície}

Basicamente, um sistema SPR é um dispositivo ótico não convencional, uma vez que não há contato direto entre a amostra e a luz incidente. Nessa técnica, a luz que incide sob um metal, geralmente uma fina camada de ouro, gera uma onda plasmônica de superfície. A onda plasmônica de superfície, por sua vez, é um campo eletromagnético longitudinal que se propaga na interface entre o metal e um dielétrico (ar, vidro, amostra). A propagação dessa onda através da interface gera um campo elétrico evanescente. Essa fração de energia oscilante entra em ressonância com os elétrons livres do metal, de forma que alterações na interface metal/ambiente promovem uma variação nas condições de ressonância do sistema. Essa variação na condição de ressonância resulta numa variação do ângulo da luz incidente, isto é, ocorre um deslocamento no ângulo SPR. Utiliza-se assim o ângulo da luz incidente como um parâmetro do controle do fenômeno da onda de plasmons de superfície, mediante um monitoramento do fator refletância x ângulo de incidência da luz. De uma maneira simplificada, pode-se dizer que a técnica SPR monitora a medida da mudança do índice de refração provocado pela ligação de uma camada molecular à superfície do metal. De forma similar ao que ocorre com a microbalança de quartzo, ela fornece informações a partir de alterações numa dada superfície.

A figura 3.30, extraída da referência [14], apresenta um esquema do aparato experimental de Kretschmann para excitação do plasma de superfície. Para informações mais detalhadas pode-se consultar as referências [14], [227] e referências internas.

A técnica SPR é relativamente recente e é normalmente utilizada em investigações de sensoriamento biológico. Uma das suas aplicações mais valiosas é a possibilidade de determinar-se parâmetros cinéticos através de gráficos de interação [14, 227-230].

As interações de biomoléculas podem ser avaliadas tanto pelas constantes cinéticas quanto pelas constantes de equilíbrio e os gráficos de interação medido por SPR possuem três etapas: fase de associação, fase de dissociação e fase de regeneração. As fases de associação e dissociação podem ser utilizadas na medida das constantes de 


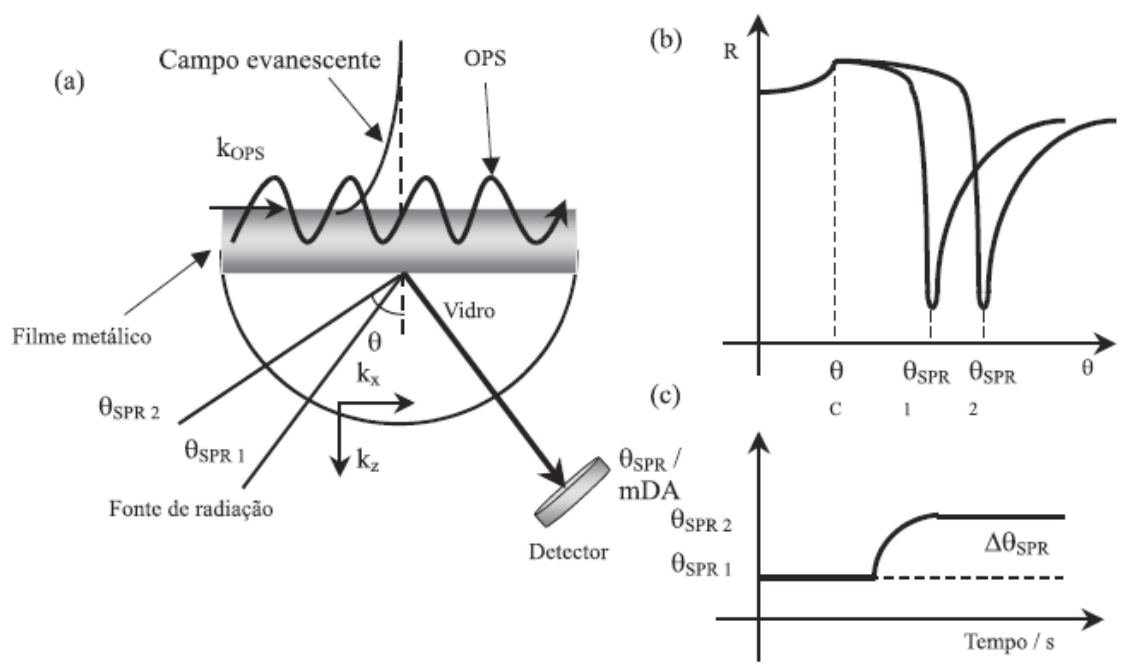

Figura 3.30: (a) Representação esquemática da configuração de Kretchmann para SPR. O dielétrico em contato com o metal possibilita a transferência ressonante de energia da onda incidente para a OPS; (b) Curvas de refletância na ausência $\left(\Theta_{S P R 1}\right)$ e presença $\left(\Theta_{S P R 2}\right)$ de espécies na superfície do filme metálico; (c) Sensorgrama esquemático representativo da relação entre o angulo SPR $\left(\Theta_{S P R}\right)$ e tempo durante a interação de espécies com a superfície do filme metálico [14].

velocidade e de equilíbrio. Essas etapas são ilustradas na figura 3.31 [231].

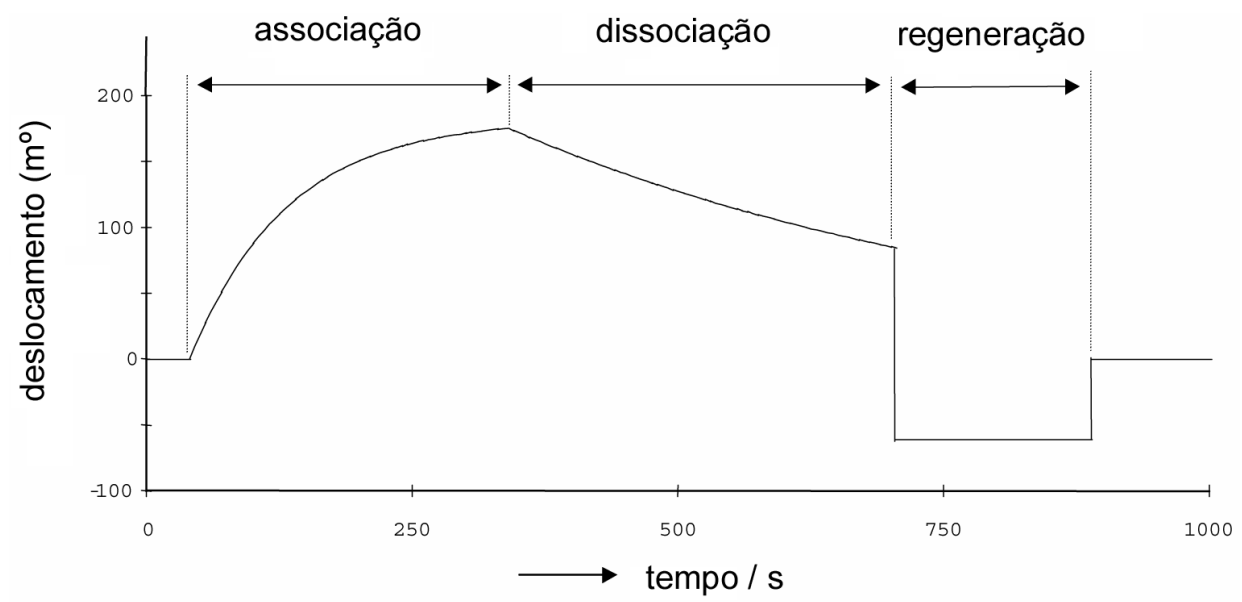

Figura 3.31: Exemplo de um gráfico de interação SPR.

Nesta figura a fase de associação evidencia a interação de um analito A em uma ligante B previamente imobilizada sobre a superfície de ouro. O complexo AB que se forma é medido através do deslocamento do ângulo de ressonância plasmônica da superfície em miligraus $\left(\mathrm{m}^{\circ}\right)$ em função do tempo. Na fase de dissociação o gráfico mostra a decomposição do complexo $\mathrm{AB}$ em A e B. A fase de regeneração mostra a 
dissociação completa do produto formado. Apenas para manter-se essa informação em mente durante a discussão do método a seguir, vale salientar que em nosso caso o ligante B corresponde a molécula de DNA duplamente entrelaçado e o analito de interesse são as supermoléculas 4-TPtTPyP e 3-TPtTPyP.

Na plotagem de interação (figura 3.31), a resposta máxima de interação do analito $\left(\mathrm{R}_{\max }\right)$ é expressa pela razão entre a massa molar do analito A e do ligante $\mathrm{B}$ multiplicadas pela valência, conforme equação 3.1:

$$
R_{\text {max }}=\frac{m m_{A}}{m m_{B}} \cdot \text { valncia }
$$

As equações que representam a interação entre as moléculas A e B pode são escritas como abaixo:

$$
\begin{aligned}
& A+B \stackrel{k_{a}}{\rightleftharpoons} A B \\
& A B \stackrel{k_{d}}{\rightleftharpoons} A+B
\end{aligned}
$$

onde:

$$
K_{A}=\frac{k_{a}}{k_{d}}=\frac{[A B]}{[A][B]}
$$

e

$$
K_{D}=\frac{k_{d}}{k_{a}}=\frac{[A][B]}{[A B]}
$$

em que $\mathrm{k}_{a}$ e $\mathrm{k}_{d}$ são constantes de velocidade. $\mathrm{k}_{a}$ é a constante de velocidade de associação, expressa $\mathrm{em} \mathrm{mol}^{-1} \cdot \mathrm{dm}^{3} \cdot \mathrm{s}^{-1}$ e $\mathrm{k}_{d}$ é a constante de velocidade de dissociação em s $\mathrm{s}^{-1} \cdot \mathrm{K}_{A}$ e $\mathrm{K}_{D}$ representam a constante de equilíbrio, onde $\mathrm{K}_{A}$ corresponde a constante de associação $\mathrm{em} \mathrm{mol}^{-1} \cdot \mathrm{dm}^{3} \mathrm{e} \mathrm{K}_{D}$ é a constante de dissociação $\mathrm{em} \mathrm{mol} \cdot \mathrm{dm}^{-3}$.

A velocidade de formação do complexo AB é representado por: 


$$
\frac{d[A B]}{d t}=k_{a}[A][B]
$$

e a velocida de dissociação é dada por:

$$
\frac{d[A B]}{d t}=-k_{d}[A B]
$$

Na fase de associação do gráfico de interação (figura 3.31), a constante de velocidade de formação corresponde a soma de ambas velocidades de reação, de acordo com:

$$
\frac{d[A B]}{d t}=k_{a}[A][B]-k_{d}[A B]
$$

A concentração do ligante B $\left(\left[\mathrm{B}_{t}\right]\right)$ é descrita em função do tempo pela relação:

$$
[B]_{t}=[B]_{t=0}-[A B]_{t}
$$

Substituindo a equação 3.9 na equação 3.8 tem-se:

$$
\frac{d[A B]}{d t}=k_{a}[A]\left([B]_{t=0}-[A B]_{t}\right)-k_{d}[A B]
$$

A formação do produto AB é medido em tempo real e o sinal é chamado de R. Como o reagente A sofre uma diminuição desprezível de concentração durante o processo de interação, essa concentração é assumida como constante. Com isso, a formação do produto AB é considerado como cinética de pseudo primeira ordem [228,229,232] e a equação 3.10 pode ser reescrita como:

$$
\frac{d[R]}{d t}=k_{a} C\left(R_{\max }-R_{t}\right)-k_{d} R_{t}
$$

rearranjando obtém-se:

$$
\frac{d[R]}{d t}=k_{a} C R_{\max }-\left(k_{a} C+k_{d}\right) R_{t}
$$



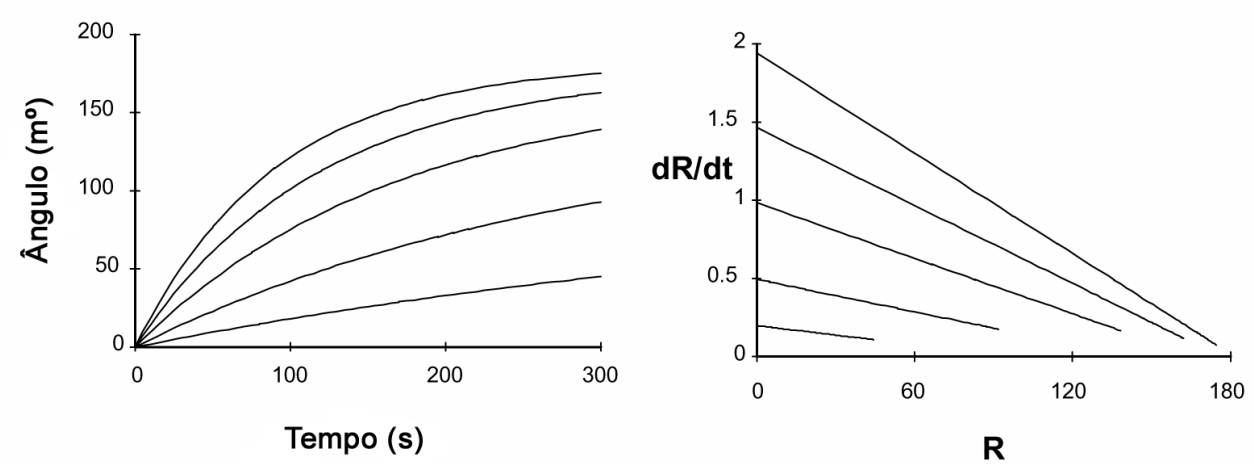

Figura 3.32: Determinação dos valores de $\mathrm{k}_{s}$ pelo método de linearização. Curvas simuladas da fase de associação de uma interação bimolecular em cinco concentrações diferentes do analito.

A equação 3.12 é tomada como uma reta $\mathrm{dR} / \mathrm{dt}=-\mathrm{K}_{s} \mathrm{R}_{t}+\mathrm{b}$ com $\mathrm{k}_{s}=\left(\mathrm{k}_{a} \mathrm{C}+\mathrm{k}_{d}\right.$ e $\mathrm{b}=\mathrm{k}_{a} \mathrm{CR}_{\max }$ ). Os parâmetros $\mathrm{k}_{s}$ e b são determinados pela regressão linear do gráfico $\mathrm{dR} / \mathrm{dt}$ versus valores $\mathrm{de}_{t}$. Por isso, este método é conhecido como método da linearização [230] e os respectivos valores são obtidos a partir dos gráficos gerados conforme a figura 3.32 .

Um arranjo superficial adequado para realização das medidas de interação das supermoléculas com DNA por SPR foi obtido através da auto-montagem de um sistema supramolecular hierárquico com níveis de organização pré-determinados.

Nessa estratégia, num primeiro momento a cisteamina adsorve sobre a superfície de Au através dos grupos tióis, uma vez que o enxofre é uma base mole e tem grande afinidade por esse metal. No segundo nível de organização, a porção catiônica da cisteamina que permanece livre permite o ancoramento do DNA através de ligações entre os resíduos amínicos positivamente carregados e os grupos fosfatos aniônicos do DNA. No terceiro nível de organização espera-se que ocorra a interação entre as supermoléculas e o DNA, e isto é o que se pretende demonstrar pelos estudos de SPR. Um modelo proposto para o arranjo dessa auto-organização hierárquica é apresentado ao final deste capítulo.

A figura 3.33 traz os resultados para o processo de associação do DNA com a cisteamina e das supermoléculas 3-TPtTPyP e 4-TPtTPyP com DNA. Entre 400 e 
500 s é observado o processo de associação entre o DNA e a cisteamina. Na região de 1500 e 1800 s é observado o processo de interação entre as supermoléculas e o DNA.

Nota-se neste caso uma variação no ângulo do feixe incidente devido a interações de ressonância plasmônica entre as supermoléculas e o DNA imobilizado sobre cisteamina. Isso demonstra um processo de interação entre os complexos supermoleculares e DNA, a qual é mais intenso para o isômero 3. Os resultados indicam também a interação do DNA com a cisteamina é bastante intensa.

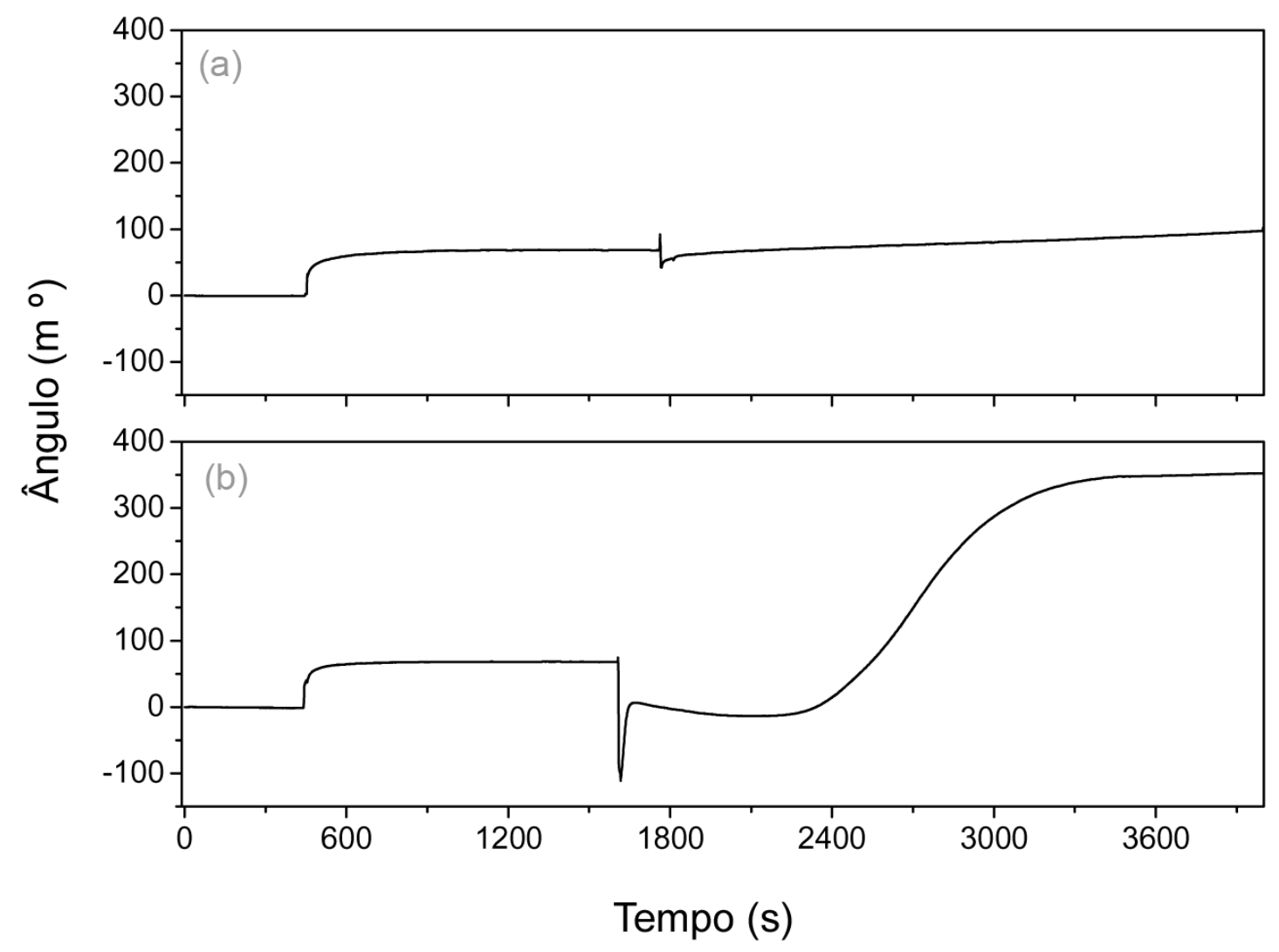

Figura 3.33: Gráfico da interação SPR de a) Cisteamina-DNA-4-TPtTPyP. b) Cisteamina-DNA-3-TPtTPyP.

Pelo uso do método de linearização descrito anteriormente foram calculados os valores das contantes de associação nas plotagens de interação SPR de DNA com cisteamina e das supermoléculas com DNA.

O valor das constantes de velocidade de associação e de equilíbrio para a interação de DNA com cisteamina foram calculadas em duplicata. Pretendeu-se assim avaliar a 


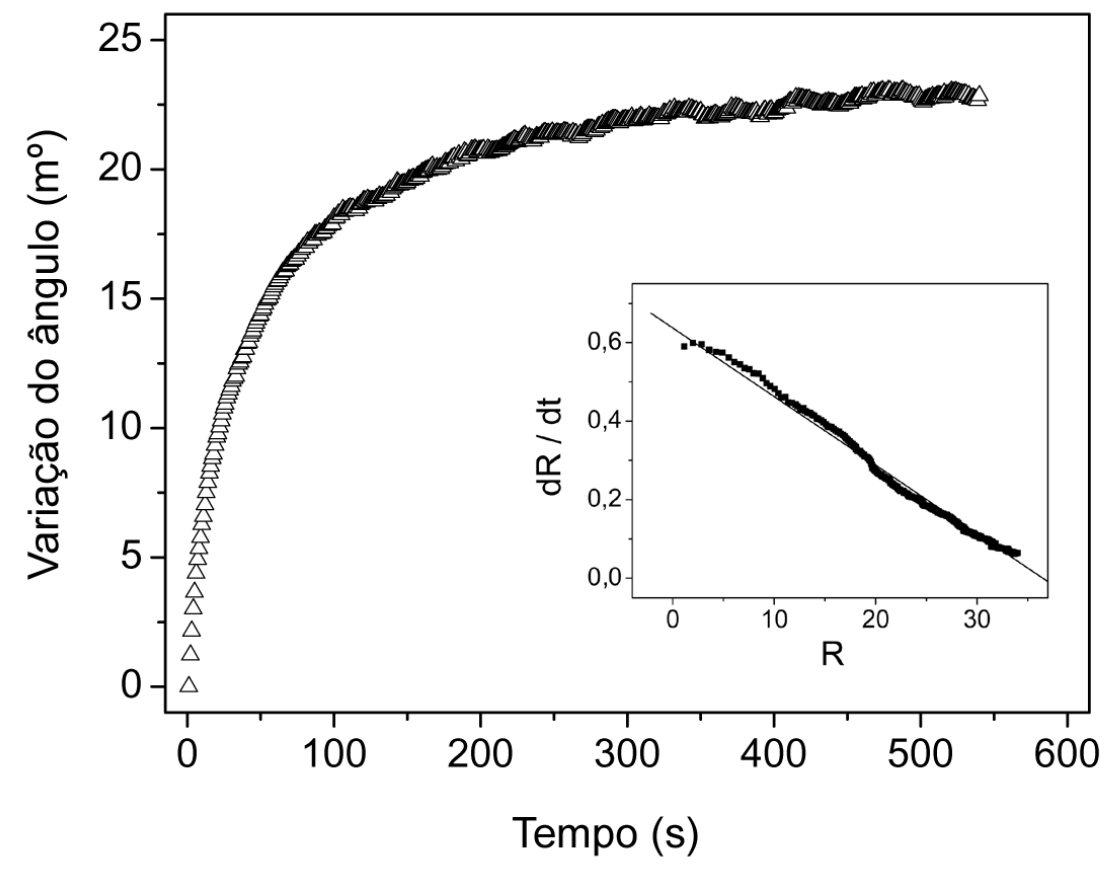

Figura 3.34: Variação do ângulo contra o tempo na interação de DNA com cisteamina, obtido a partir da figura 3.33(a).

reprodutibilidade deste processo.

Esses valores, obtidos a partir do gráfico das figuras 3.33(a) e 3.34 na interação de DNA com a cisteamina, são: $\mathrm{k}_{a}=330 \mathrm{~mol}^{-1} \cdot \mathrm{dm}^{3} \cdot \mathrm{s}^{-1}, \mathrm{k}_{d}=5,98 \times 10^{-2} \cdot \mathrm{s}^{-1}$ e $\mathrm{K}_{A}$ $5,53 \times 10^{3} \mathrm{~mol}^{-1} \mathrm{dm}^{3}$, respectivamente.

Quando estas constantes são calculadas a partir do gráfico 3.33(b) e 3.35, obtemse os valores de $\mathrm{k}_{a}=225 \mathrm{~mol}^{-1} \cdot \mathrm{dm}^{3} \cdot \mathrm{s}^{-1}, \mathrm{k}_{d}=3,80 \mathrm{x} 10^{-2} \mathrm{~s}^{-1}$ e $\mathrm{K}_{A} 5,58 \times 10^{3} \mathrm{~mol}^{-1} \mathrm{dm}^{3}$ para a velocidade de associação e constante de equilíbrio na interação de DNA com a cisteamina $^{1}$

Após imobilização do DNA na superfície da cisteamina foram realizados os estudos de interação das supermoléculas 3-TPtTPyP e 4-TPtTPyP com DNA. No caso da 4-TPtTPyP a variação de ressonância plasmônica foi pouco expressiva, conforme ilustrado na figura 3.33(a), impossibilitando a obtenção de resultados confiáveis para

\footnotetext{
${ }^{1} \mathrm{~A}$ escala de tempo nos gráficos das figuras 3.34, 3.35 e 3.36 corresponde ao intervalo decorrido para cada evento de associação dentro da escala de tempo integral do experimento mostrado na figura 3.33 .
} 


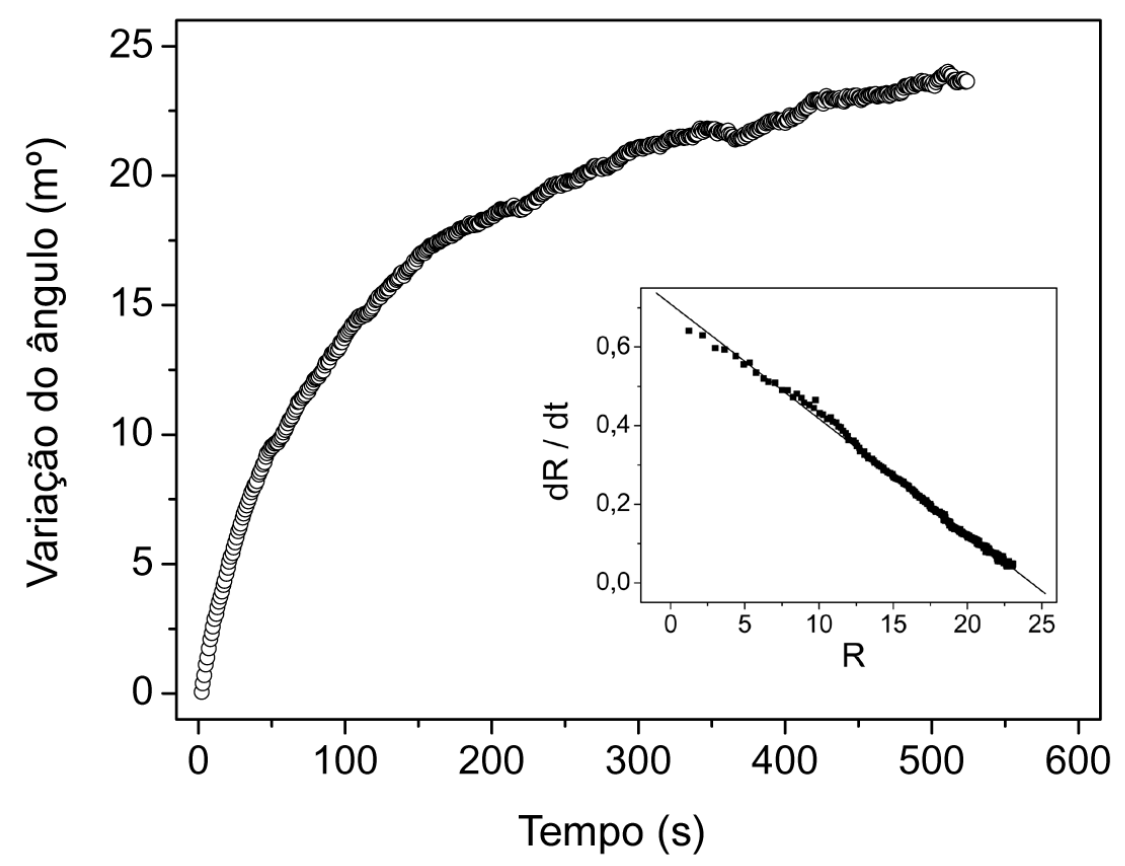

Figura 3.35: Variação do ângulo contra o tempo na interação de DNA com cisteamina, obtido a partir da figura 3.33(b).

o cálculo das constantes de velocidade de associação e de equilíbrio.

Por outro lado, para a 3-TPtTPyP as medidas revelaram uma intensa interação da supermolécula com o DNA, tal como observado nas titulações espectrofotométricas. Com o auxílio dos gráficos apresentados nas figuras 3.33(b) e 3.36 e utilizando o método da linearização, pôde-se calcular os valores de constante de velocidade de associação e equilíbrio. Os valores obtidos são: $\mathrm{k}_{a}=313 \mathrm{~mol} .^{-1} \cdot \mathrm{dm} 3 . \mathrm{s}^{-1}, \mathrm{k}_{d}=7,2 \times 10^{-3} \mathrm{~s}^{-1}$ e $\mathrm{K}_{A}$ é $4,4 \times 10^{4} \mathrm{~mol}^{-1} \mathrm{dm}^{3}$.

Esse valores denotam um forte acoplamento do DNA com a 3-TPtTPyP, sugerindo a ocorrência de interações eletrostáticas e intercalativas, conforme proposto na figura 3.37 .

Quanto aos resultados de SPR obtidos para a 4-TPtTPyP, a falta de sucesso neste caso pode ser devida a formação de agregados que precipitam na superfície do DNA de forma irregular ao invés de formar um filme superficial adsorvido. Pelo menos esta é a interpretação que se pode propor no momento tendo por base os dados da titulação 


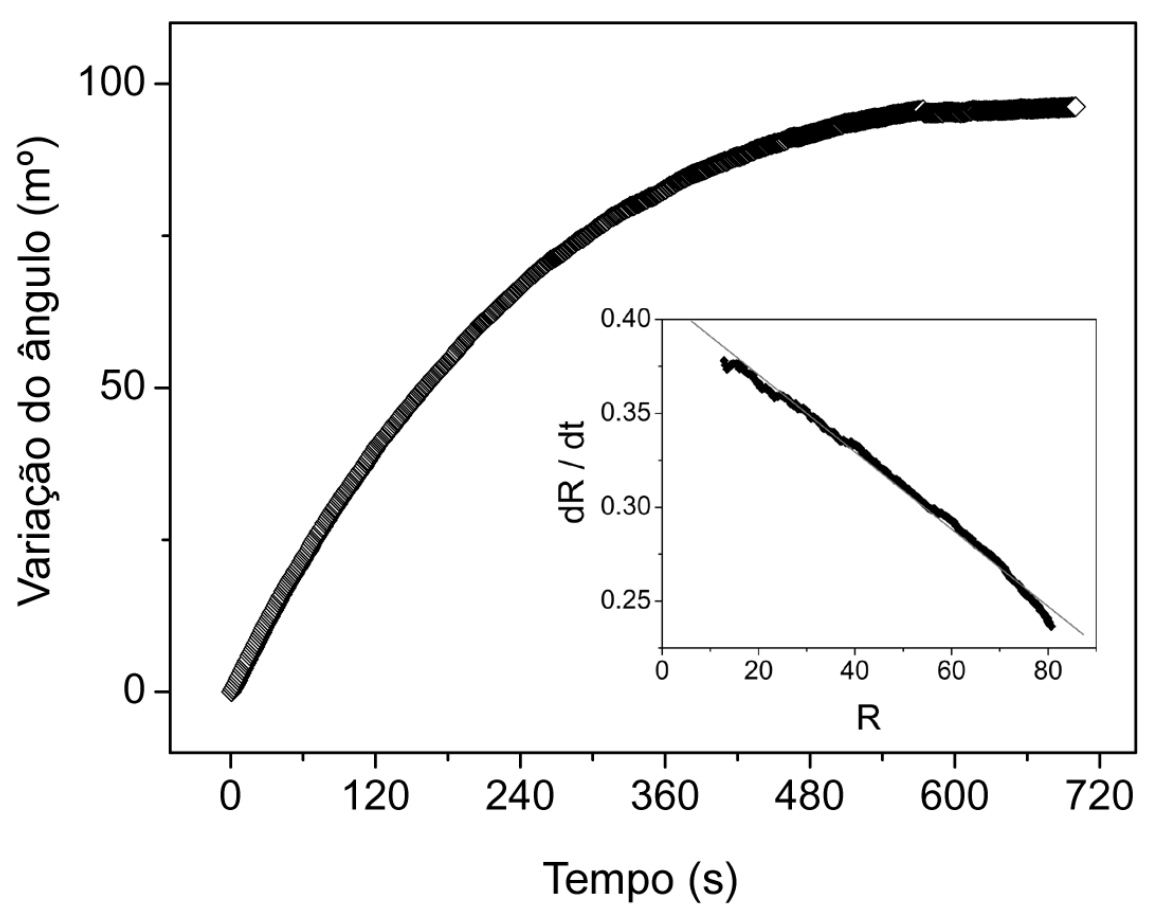

Figura 3.36: Variação do ângulo contra o tempo na interação de 3-TPtTPyP com DNA, obtido a partir da figura 3.33(b).

espectrofotométrica. A figura 3.38 ilustra $\mathrm{O}$ modelo de interação sugerido para este isômero com o DNA, sendo que este arranjo seria governado por forças de associação de caráter eletrostático.

A tabela 3.3 resume as constantes calculadas para as interações SPR.

Tabela 3.3: Constantes de velocidade de associação e de equilíbrio na interação SPR de cisteamina-DNA-3TPtTPyP.

\begin{tabular}{l|c|c|r}
\hline Interação & $\mathrm{k}_{a}\left(\mathrm{~mol}^{-1} \cdot \mathrm{dm}^{3} \cdot \mathrm{s}^{-1}\right)$ & $\mathrm{k}_{d}\left(\mathrm{~s}^{-1}\right)$ & $\mathrm{K}_{A}\left(\mathrm{~mol}^{-1} \mathrm{dm}^{3}\right)$ \\
\hline \hline cisteamina-DNA(a) & 330 & $5,98 \times 10^{-2}$ & $5,53 \times 10^{3}$ \\
cisteamina-DNA(b) & 225 & $3,80 \times 10^{-2}$ & $5,58 \times 10^{3}$ \\
cisteamina-DNA-3TPtTPyP & 313 & $7,2 \times 10^{-3}$ & $4,4 \times 10^{4}$ \\
\hline
\end{tabular}




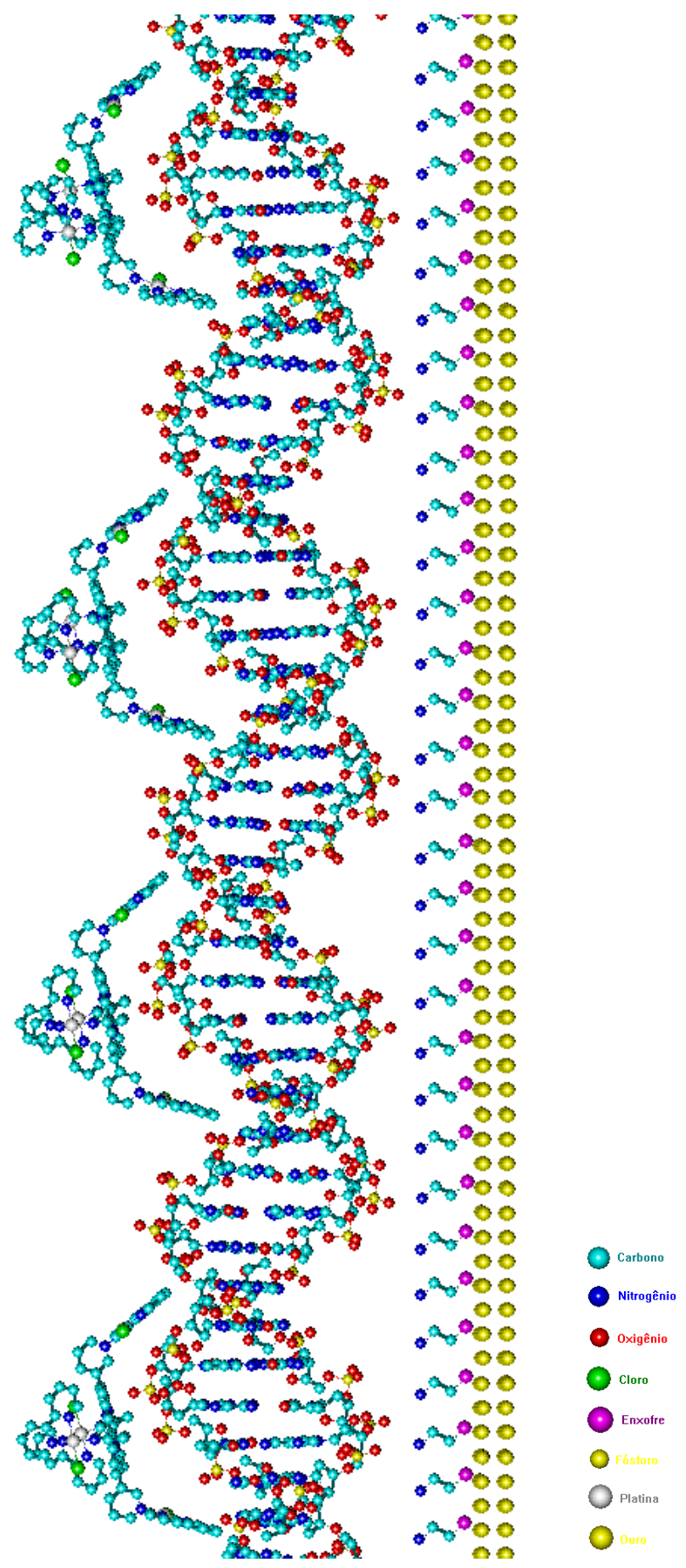

Figura 3.37: Modelo proposto para o arranjo supramolecular hierárquico do sistema Au-cisteamina-DNA-3TPtTPyP 


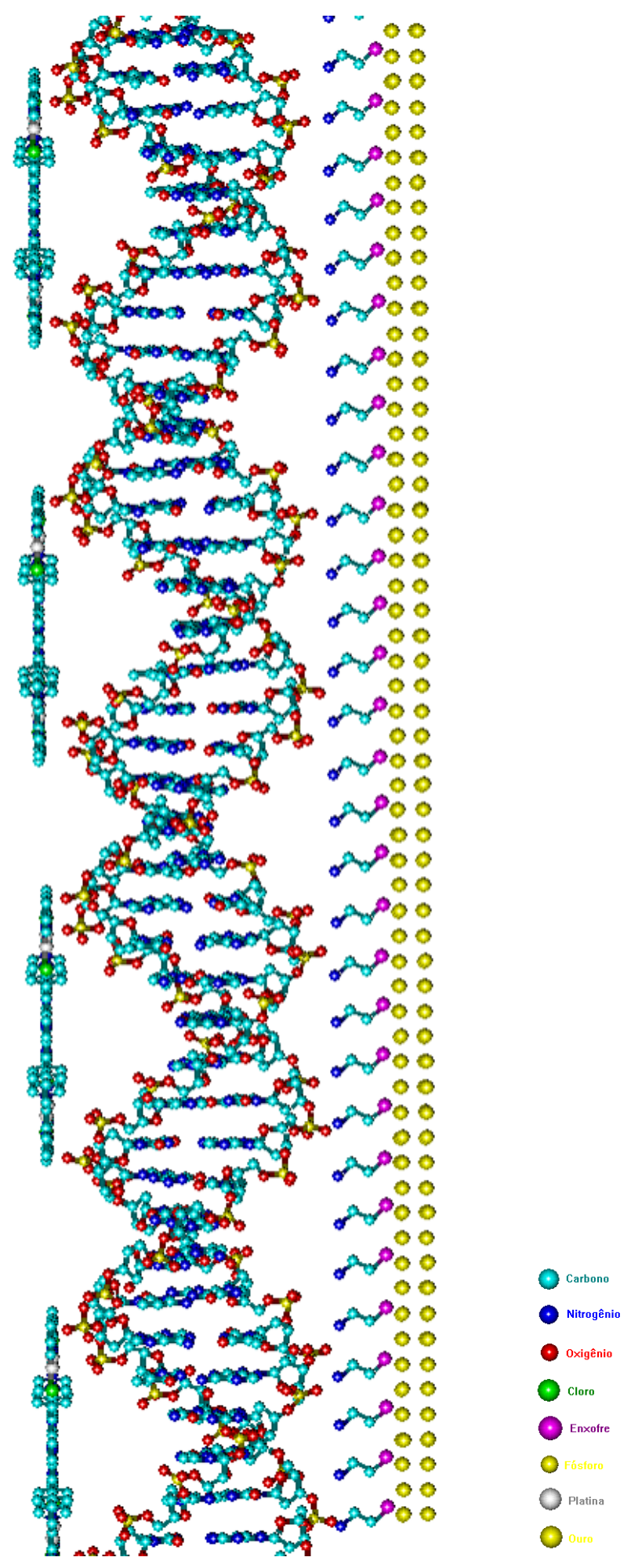

Figura 3.38: Modelo proposto para o arranjo supramolecular hierárquico do sistema Au-cisteamina-DNA-4TPtTPyP 


\subsection{Complexos Associados por Pareamento Iônico}

Conforme exposto na introdução deste trabalho, a investigação da formação de espécies supramoleculares por pareamento iônico tem valor não só no sentido de avaliar-se a formação de arranjos auto-montados, mas também na preparação de dispositivos moleculares, especialmente eletrodos quimicamente modificados. Tal como mencionado, esses arranjos eletrostáticos tem contribuído na estabilização dos filmes supramoleculares sobre a superfície dos eletrodos. Claro que uma vez que se tenha caracterizado o arranjo formado, outras aplicações podem ser testadas.

A auto-montagem das espécies associadas eletrostaticamente foi obtida pela titulação das soluções das supermoléculas com CuPcTS e também pela titulação reversa. Em ambos os casos empregou-se sempre soluções com duas ordens de grandeza de diferença nas concentrações relativas para minimizar o efeito da diluição. Apenas para maior clareza, a figura 3.39 traz a representação estrutural da CuPcTS.

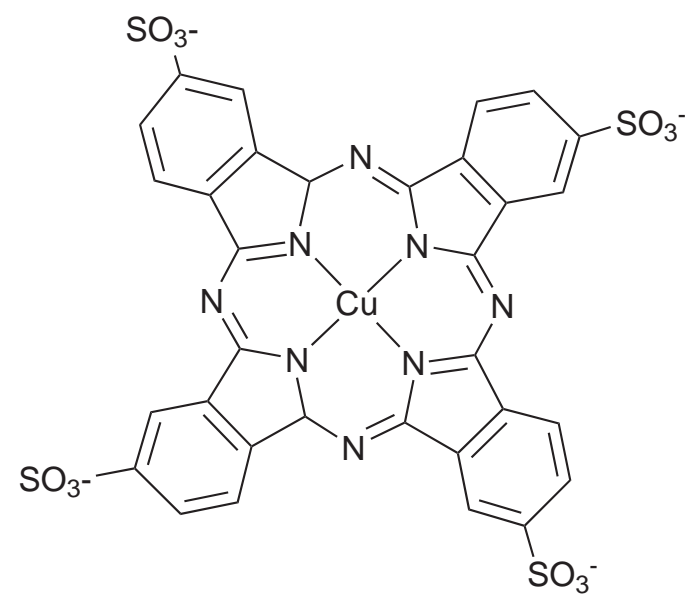

Figura 3.39: Representação estrutural da CuPcTS.

As titulações da ftalocianina tetra-aniônica com as supermoléculas apresentaram o mesmo comportamento para os dois isômeros. Durante as titulações observou-se deslocamento batocrômico e um forte decréscimo na absortividade molar da banda $\mathrm{Q}$ da ftalocianina. O mesmo efeito foi verificado para a banda Soret das porfirinas na titulação inversa. No ponto de equivalência, a absortividade molar da banda Soret da 
4-TPtTPyP sofre um decréscimo para 30\% do valor inicial e a banda Q da ftalocianina sofre um decréscimo para 15\%. Como pode ser visto nas figuras 3.40 e 3.41, o espectro resultante difere marcadamente da soma dos reagentes, confirmando a formação de novas espécies. As soluções apresentam coloração vermelha para as supermoléculas, azul para a ftalocianina e verde para o par iônico.

Essas variações espectrais também sugerem uma extensa sobreposição de orbitais entre o sistema aromático dos anéis e estudos prévios da literatura tem demonstrado que a energia de associação não é apenas conseqüência da carga, mas a interação $\pi$ entre os anéis tem também papel fundamental na formação do par iônico [233, 234].

A estequiometria do par iônico foi determinada pelo método de Job [117, 202, 203]. Esse método estabelece que o espectro UV/VIS resultante da mistura de dois compostos em solução corresponde a soma da absorvância dos compostos individuais. Qualquer desvio dessa soma evidencia a formação de uma nova espécie no meio.

Os diagramas de Job mostrados nas figuras 3.42 e 3.43 foram obtidos a partir da equação 3.13. Nessa equação, x corresponde a fração molar da espécie em questão, $\mathrm{A}_{\text {exp }}$. equivale a absorvância medida após a adição de cada alíquota do titulante em um dado comprimento de onda, $C_{P c}$ e $C_{P}$ correspondem a concentração total da ftalociona e das respectivas supermoléculas, $\epsilon_{P c}$ e $\epsilon_{P}$ são a absortividade molar da ftalocianina e da respectiva supermolécula no comprimento de onda considerado para $\mathrm{A}_{\text {exp. }}$, geralmente tomado na banda de máxima absorvância do composto.

$$
F_{x}=\frac{A_{\exp .}-\left(C_{P c} \cdot \epsilon_{P c}+C_{P} \cdot \epsilon_{P}\right)}{\left(C_{P c}+C_{P}\right)}
$$

Apesar dos diagramas de Job apresentarem um leve desvio dos valores ideais de 0,33 para a fração molar de CuPcTS e 0,67 para a fração molar do complexo catiônico, esses resultados são consistentes com uma estequiometria de 2 porfirinas catiônicas por ftalocianina. Ou seja, o sistema se auto-organiza como heterotrímeros, onde a ftalocianina é sanduichada por dois complexos tetraplatinados, numa geometria facea-face. Um modelo desta organização é apresentado na figura 3.44. 

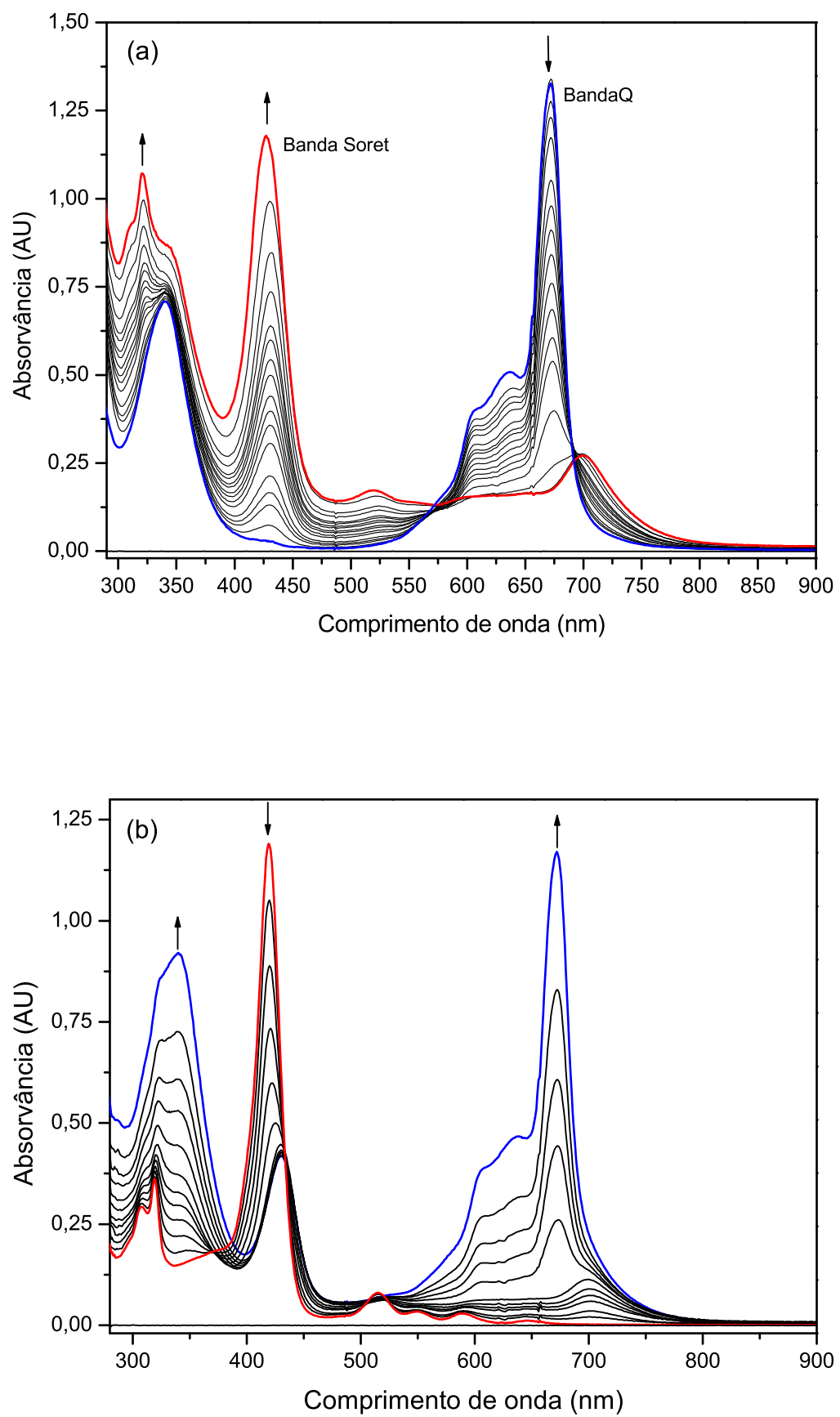

Figura 3.40: Gráfico das titulações envolvendo as espécies 4-TPtTPyP e CuPcTS: a) Titulação da CuPcTS com 4-TPtTPyP. b) Titulação inversa. 

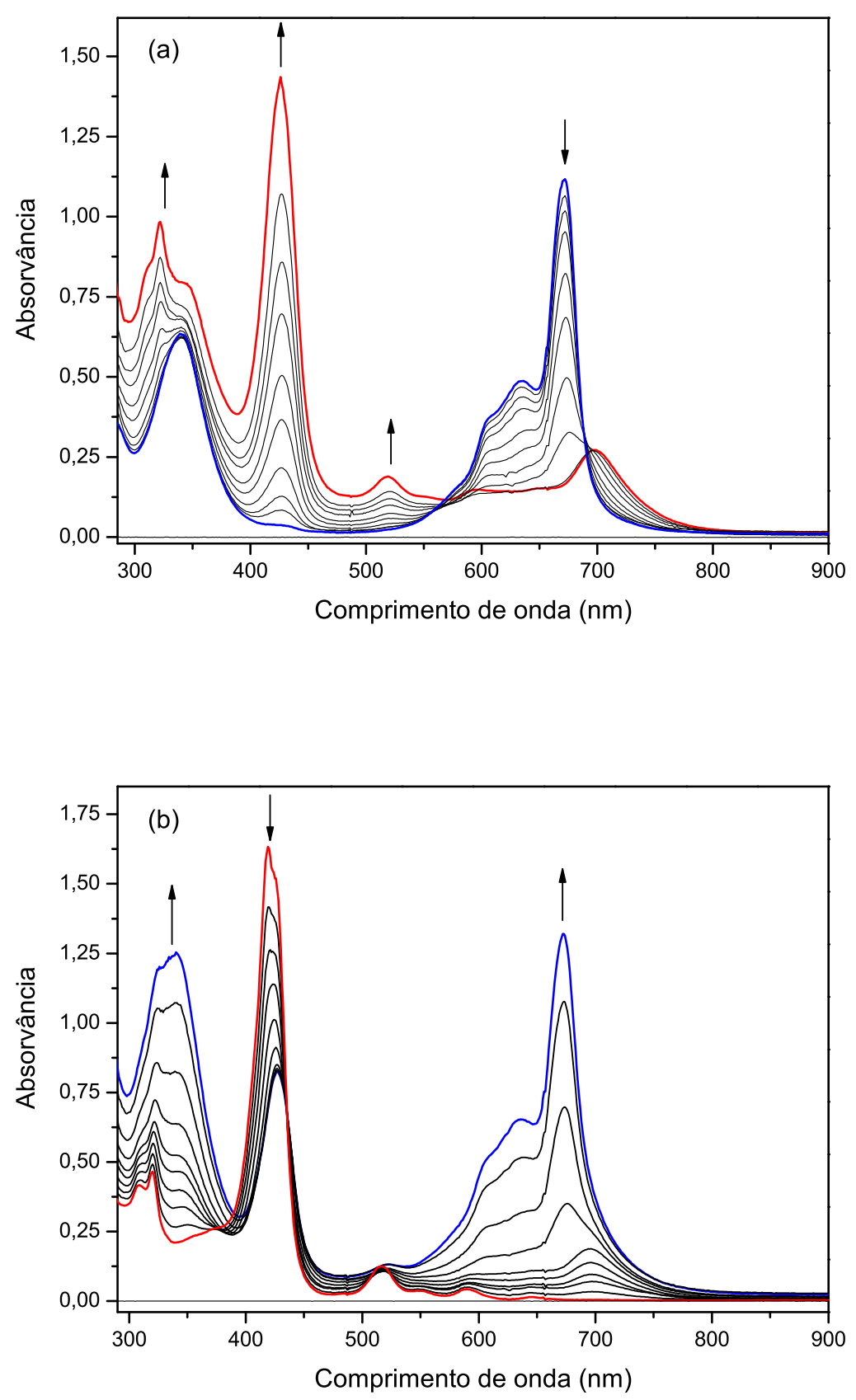

Figura 3.41: Gráfico das titulações envolvendo as espécies 3-TPtTPyP e CuPcTS: a) Titulação da CuPcTS com 3-TPtTPyP. b) Titulação inversa. 


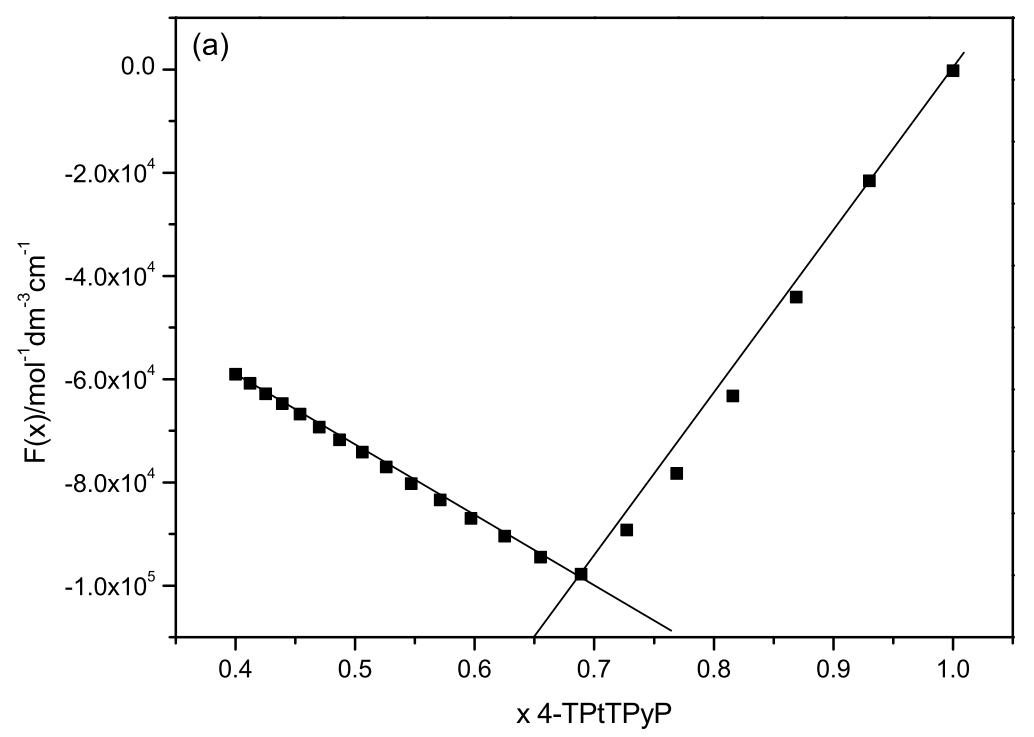

Figura 3.42: Diagrama de Job para o sistema a) 4-TPtTPyP ${ }^{4+} / \mathrm{CuPcTS}^{4-}, \lambda=420$ $\mathrm{nm}$.

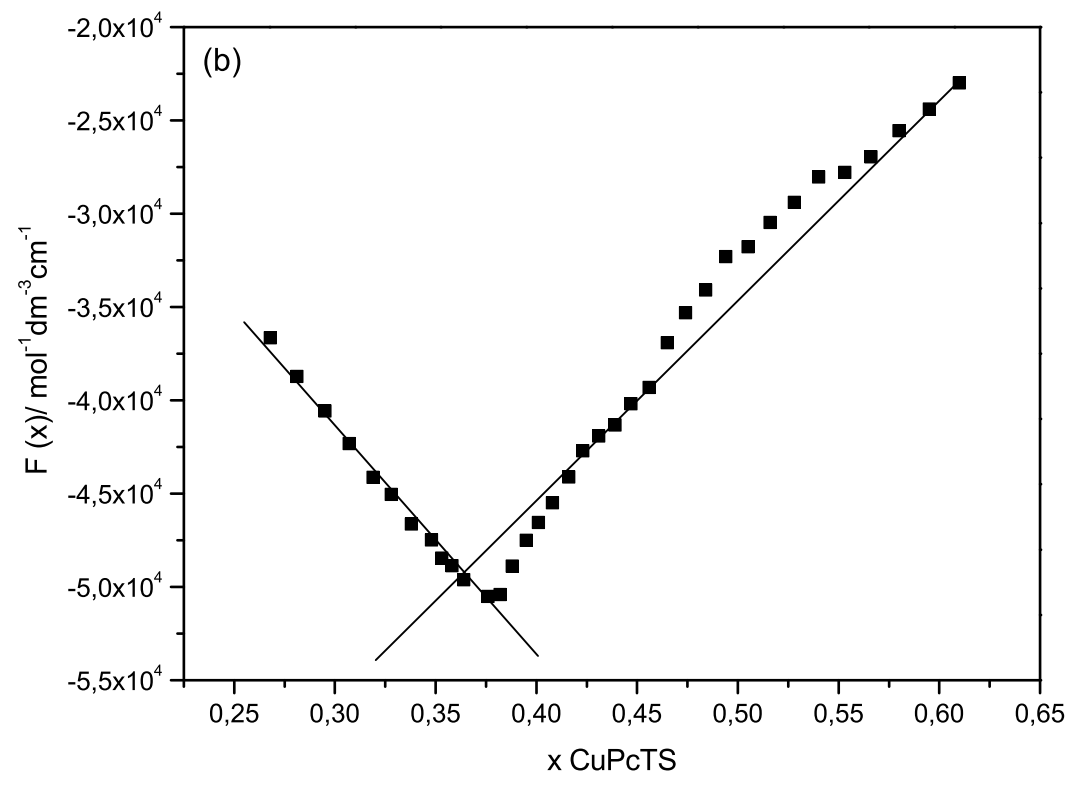

Figura 3.43: Diagrama de Job para o sistema 3-TPtTPyP ${ }^{4+} / \mathrm{CuPcTS}^{4-}, \lambda=672$ nm. 

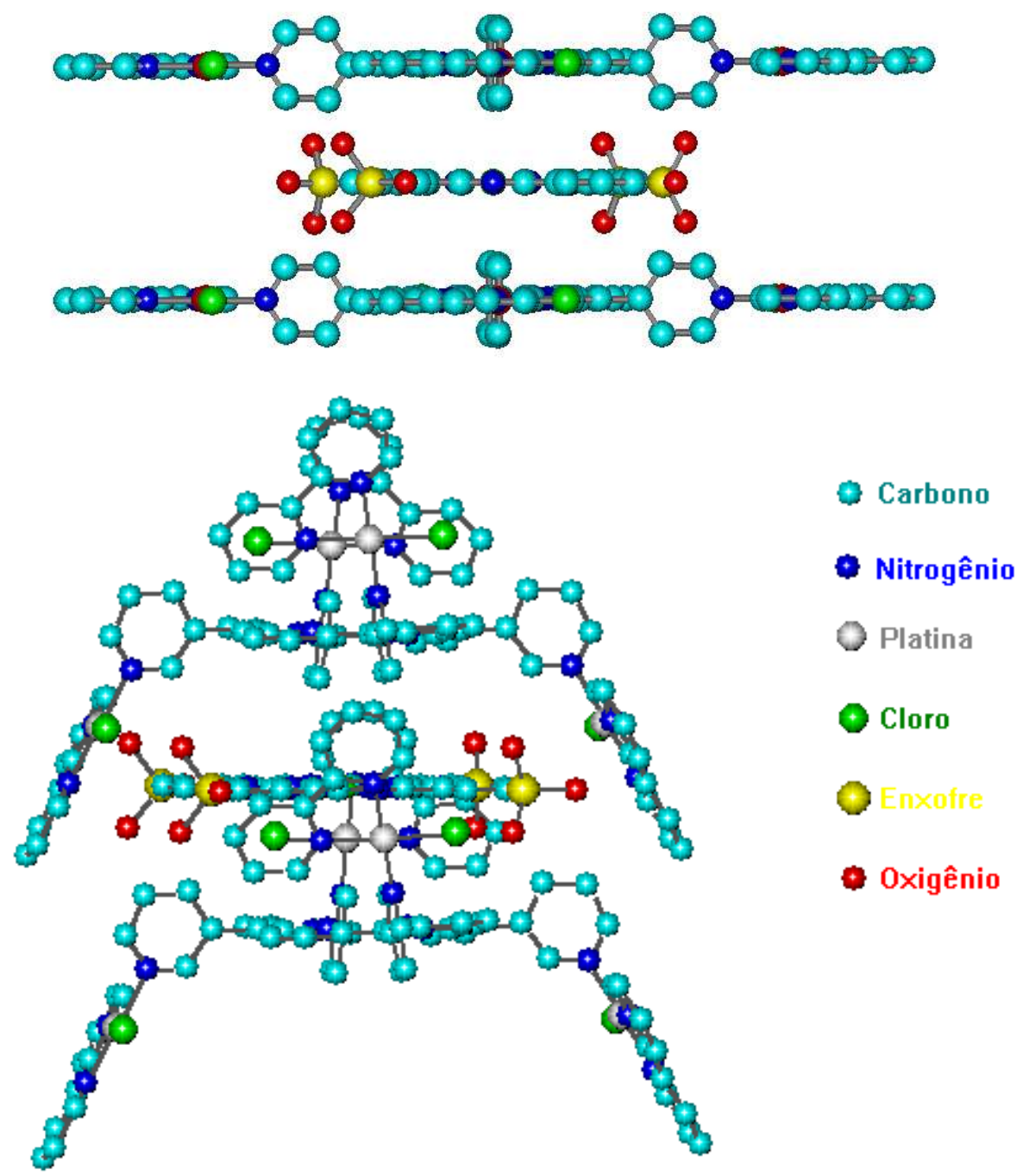

Figura 3.44: Modelo dos heterotrímeros formado pelas espécies 4$\mathrm{TPtTPyP}^{4+} / \mathrm{CuPcTS}^{4-}$ e 3-TPtTPyP ${ }^{4+} / \mathrm{CuPcTS}^{4-}$. 


\subsection{Microscopia de Varredura por Sonda}

As imagens de microscopia de varredura por sonda podem ser obtidas por três modos de operação diferentes: a) SPM de contato; b) SPM de não-contato e c) SPM de contato intermitente.

Esses modos de operação, por sua vez, são normalmente aplicados empregando-se força constante entre a ponta e a superfície da amostra. Neste caso, a força é monitorada através da deflexão do laser no sistema cantilever-ponta durante a varredura, e medida através de um fotodetector, conforme ilustrado na figura 3.45 [235].

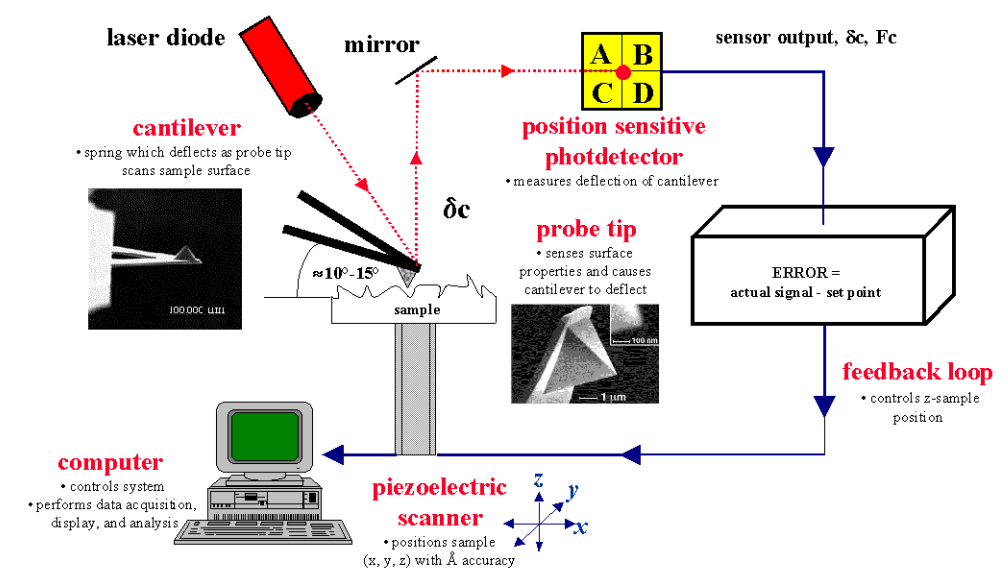

Figura 3.45: Esquema geral dos componentes e de suas funções num microscópio de força atômica.

As forças que atuam entre a superfície da amostra e a ponta do cantilever no modo SPM são forças de van der Waals. No modo SPM de contato, a ponta permanece em contato permanente com a amostra durante a varredura, estando sujeita a forças repulsivas da ordem de $10^{-6} \mathrm{~N}$. Assim, quando ela cruza um degrau de amostra, experimenta uma força de repulsão maior, provocando uma contração do cantilever no sentido -Z. Quando a ponta atravessa um buraco da amostra, ela experimenta um relaxamento da força repulsiva, e o sistema de realimentação que mantém a força constante promove uma deflexão no sentido + Z. As variações sofridas pelo cantilever no eixo Z durante a varredura, medidas ponto-a-ponto na amostra (plano X-Y) formam a imagem da superfície [236]. 


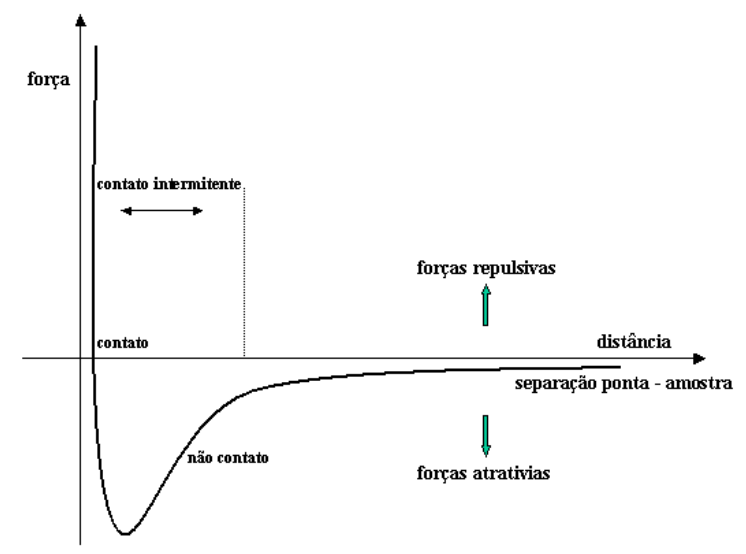

Figura 3.46: Curva de potencial das forças de van der Waals e os modos de operação na microscopia de varredura por sonda.

Em nosso caso a aquisição das imagens SPM foi realizada no modo contato intermitente (MAC Mode) com força constante. Nesse modo, o cantilever oscila em sua freqüência de ressonância, e na máxima amplitude de oscilação ela toca a superfície. Na técnica MAC Mode a amplitude de oscilação é de 5 a 10 nm e a ponta do cantilever experimenta forças da ordem de $1 \mathrm{nN}$ a $1 \mathrm{pN}$. A operação pode se dar ainda tanto no regime repulsivo como atrativo, conforme ilustrado na figura 3.46. Para que o cantilever atinja sua freqüência de ressonância, ele é recoberto com um filme magnético e excitado através de um campo magnético oscilante que atua sobre ele.

O modo contato intermitente também opera com força constante. De maneira similar ao SPM de contato, o sistema de realimentação do cantilever mantém a amplitude de oscilação constante e a variação da força aplicada em função do ângulo de deflexão do laser dá origem a imagem da superfície da amostra.

Como mostrado nas figuras 3.47 e 3.48 os filmes finos das espécies 4-TPtTPyP e 3-TPtTPyPexibem pequenos agregados cobrindo a maior parte da superfície da mica e as estruturas mais proeminentes consistem de padrões colunares, refletindo a tendência das porfirinas supramoleculares em formarem agregados auto-montados por empilhamento $\pi$. 

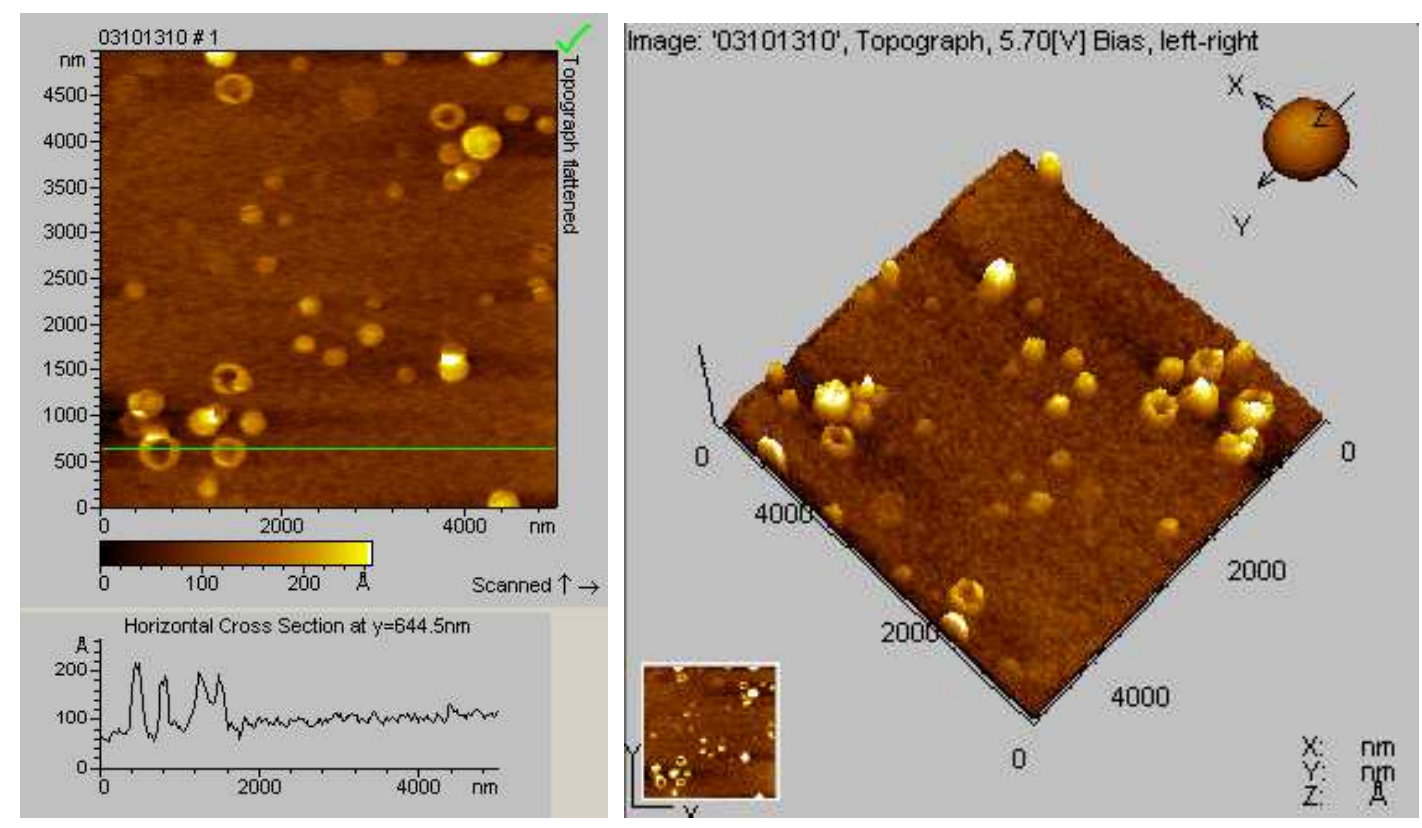

Figura 3.47: Imagem SPM $(5 \times 5 \mu \mathrm{m})$ no modo contato intermitente (MAC Mode) do filme de 4-TPtTPyP depositado sobre mica.

As imagens topográficas revelam que os domínios colunares para a 4-TPtTPyP são maiores que os observados para a 3-TPtTPyP. No primeiro caso, a estrutura das colunas lembram toróides ou tubos planos, enquanto que no segundo caso vemos um cone sólido. A altura dessas nanoestruturas variam de $10 \mathrm{~nm}$ para a 3-TPtTPyP a 20 nm em média para a 4-TPtTPyP.

De acordo com os modelos moleculares calculados (figuras 3.11 e 3.12, página 71), a geometria da 4-TPtTPyP induz um impedimento estérico mínimo entre os complexos de platina periféricos. Desse modo, acredita-se que essas moléculas planares formem um padrão de agregação onde são empacotadas como discos sobrepostos (figura 3.50), interagindo entre si lateral e verticalmente por meio de interações $\pi$ e metal-metal, de forma similar ao observado para complexos de platina monoméricos e supramoleculares reportados na literatura $[12,166,168,169]$. Desse modo, essas interações envolvem tanto os complexos de platina periféricos como o centro porfirínico.

Por outro lado, a 3-TPtTPyP exibe cada par oposto dos complexos de platina(II)bipiridina numa conformação fora do plano, em conseqüência do pronunciado impedimento estérico conferido pela geometria da 3-TPyP. Por causa dessa geometria tipo 

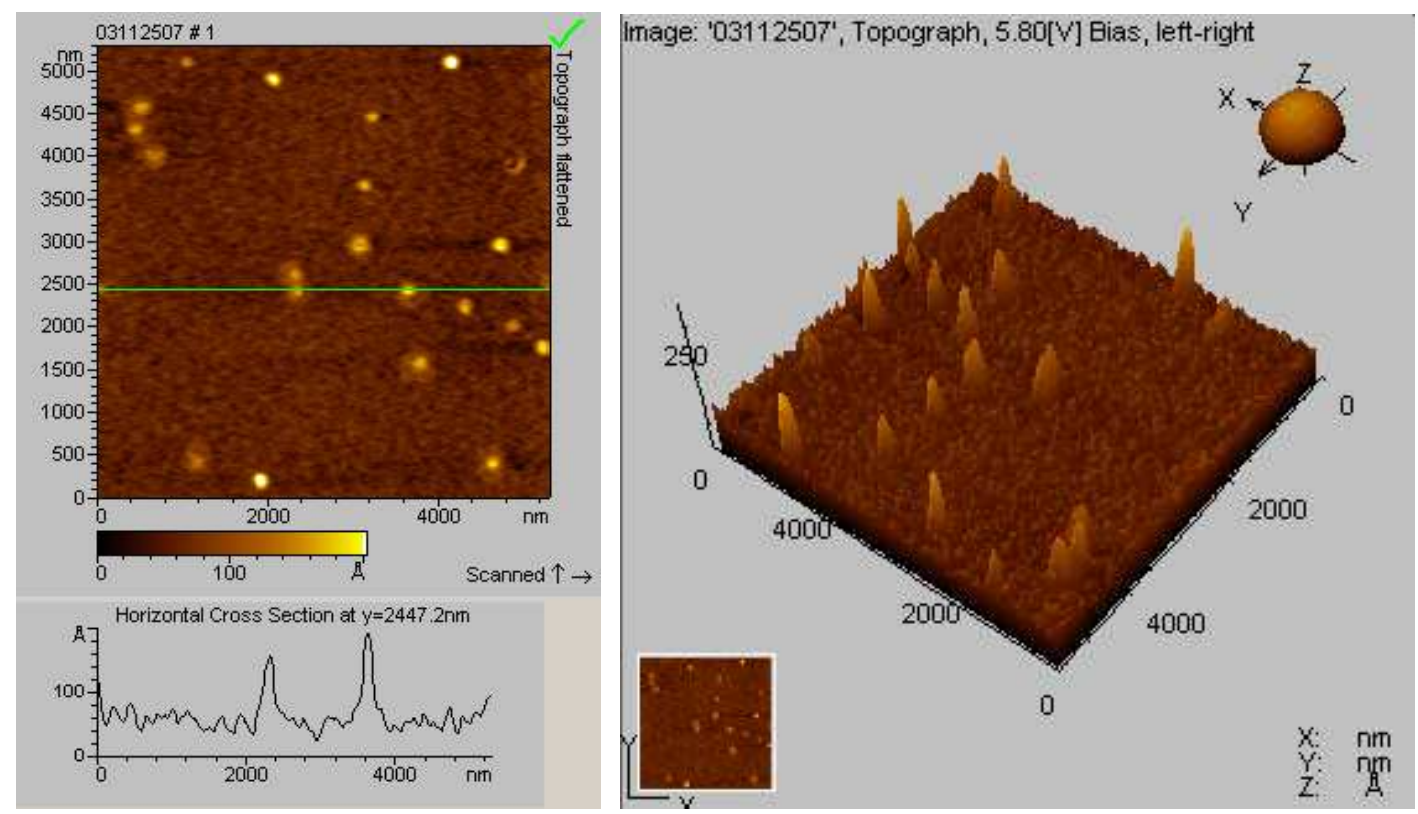

Figura 3.48: Imagem SPM $(5 \times 5 \mu \mathrm{m})$ no modo contato intermitente do filme de 3TPtTPyP depositado sobre mica.

cela, acredita-se que o empilhamento $\pi-\pi$ deve favorecer uma interação vertical entre as moléculas de 3-TPtTPyP (figura 3.49), gerando as respectivas estruturas tipo cone observados na microscopia (figura 3.48).

Levando em conta esses aspectos, são apresentados nas figuras 3.49 e 3.50 modelos sugestivos para a origem das nanoestruturas observadas nos filmes. A figura 3.50 ilustra uma distribuição tipo disco, onde cada supermolécula seria o topo de uma coluna molecular. A circunferência interna do disco corresponderia assim às cavidades observadas nos resultados de SPM para a espécie 4-TPtTPyP.

Nos filmes dos pares iônicos um padrão similar de nanoestruturas cônicas com altura média de $20 \mathrm{~nm}$ é verificado (figuras 3.51 e 3.52), refletindo, em ambos os casos, a predominância de empilhamentos $\pi-\pi$ enlargados por forças eletrostáticas e forças laterais mais fracas. Essas respectivas interações devem ser, novamente, mais fortes no sistema 4-TPtTPyP ${ }^{4+} / \mathrm{CuTSPc}^{4-}$ devido a geometria planar. Isto é refletido pela maior densidade de estruturas cônicas presentes no filme desta espécie, em comparação ao filme da espécie com maior impedimento estérico 3-TPtTPyP ${ }^{4+} / \mathrm{CuTSPc}^{4-}$ (figura 3.52). Em ambos os casos as espécies devem se auto-organizar como discos 

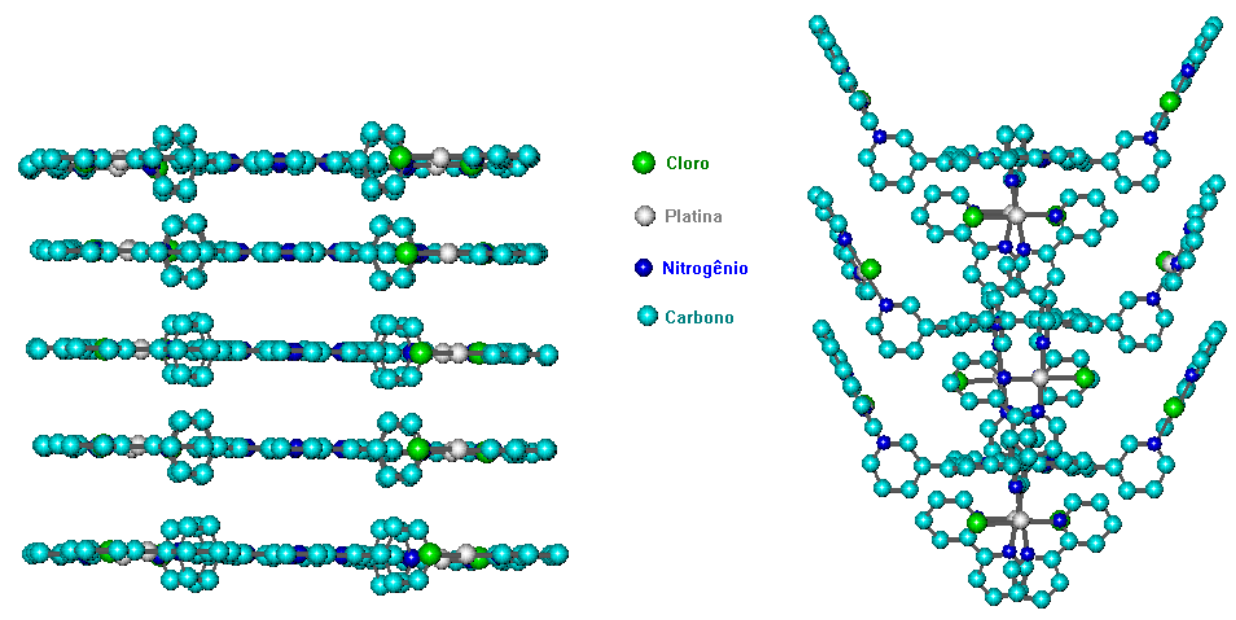

Figura 3.49: Modelo de organização proposta para a origem das estruturas colunares observadas nas imagens SPM da 4-TPtTPyP e 3-TPtTPyP.

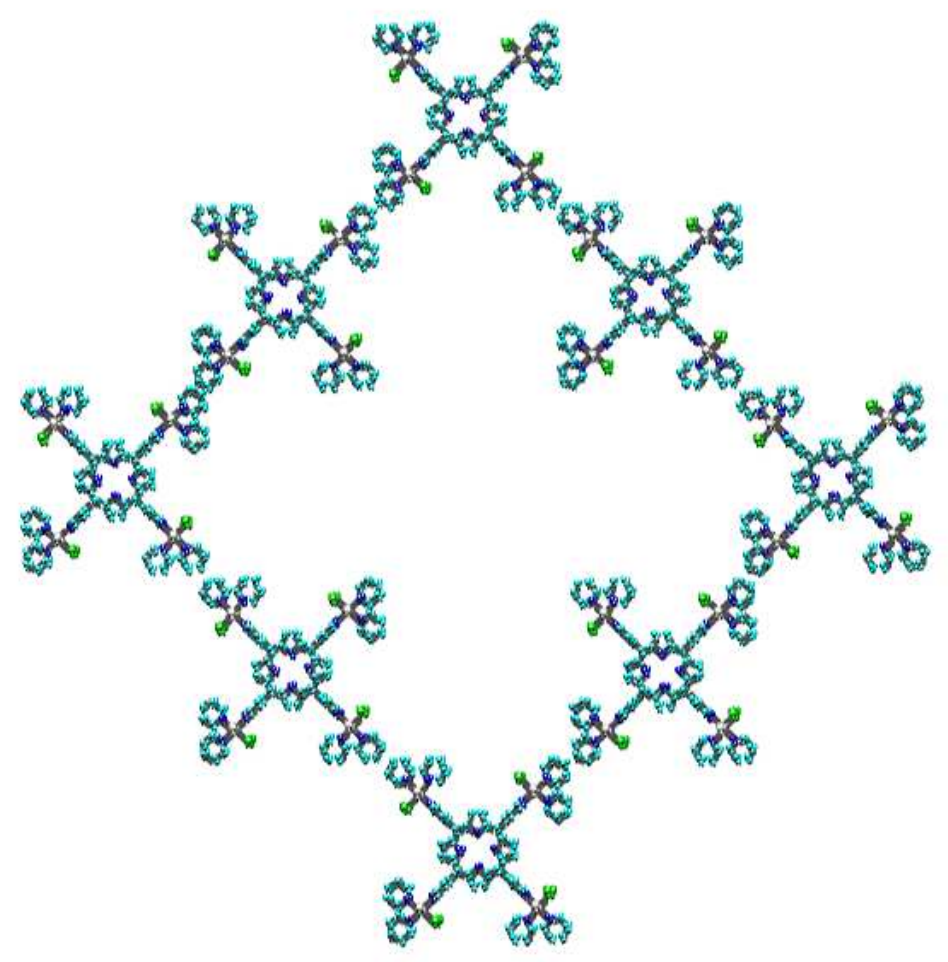

Figura 3.50: Modelo de organização proposta para a origem das estruturas colunares tipo tubo observado nas imagens SPM da 4-TPtTPyP. 

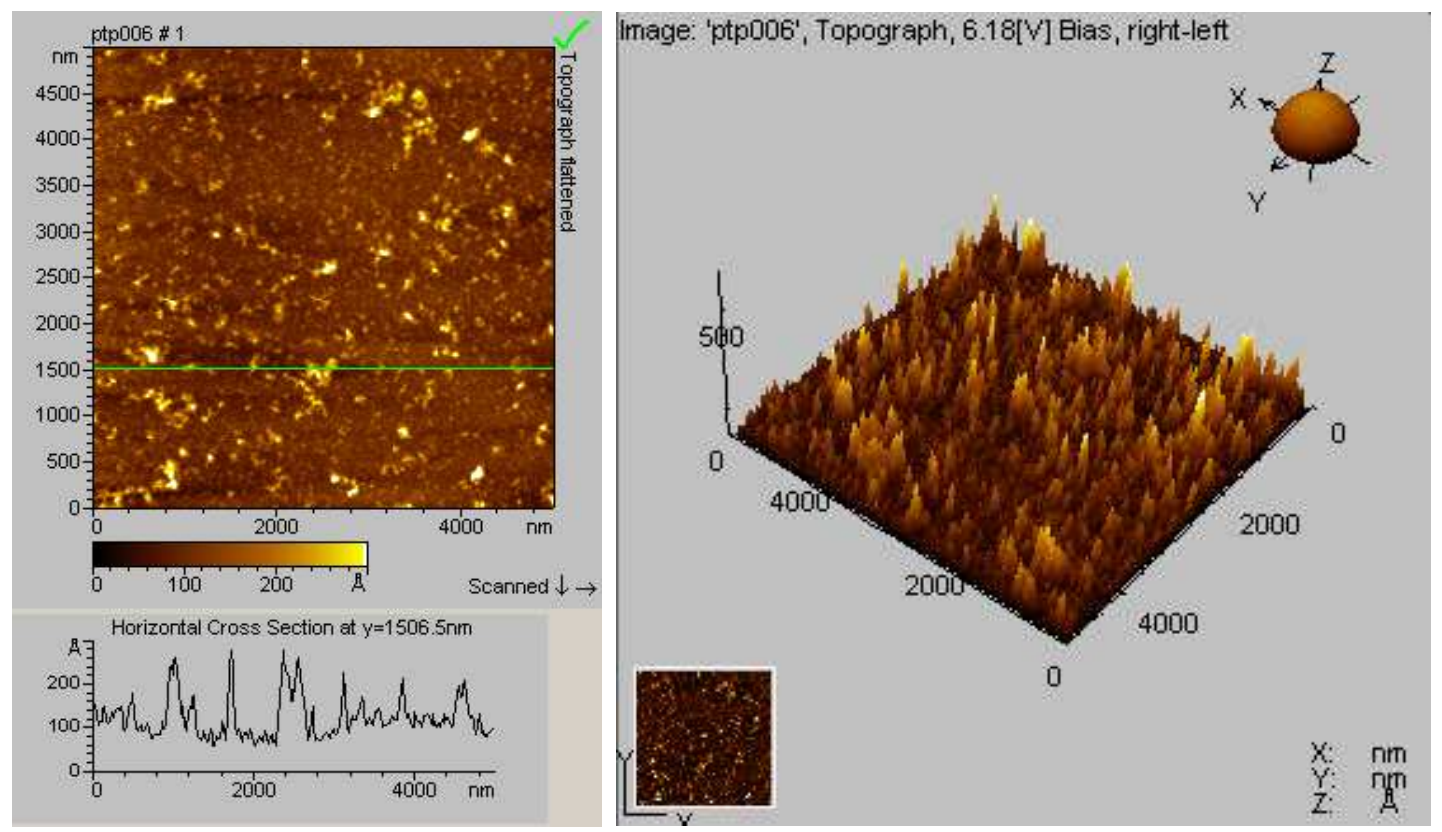

Figura 3.51: Imagem SPM $(5 \times 5 \mu \mathrm{m})$ no modo contato intermitente do filme de 4TPtTPyP/CuPcTS depositado sobre mica.

empilhados de heterotrímeros, seguindo a mesma relação estequiométrica determinada nas titulações UV-VIS.

Por fim, tanto para os filmes dos pares iônicos como para as supermoléculas livres foi verificado que as espécies tendem a formar filmes altamente homogêneos que recobrem a maior área da superfície da mica. 

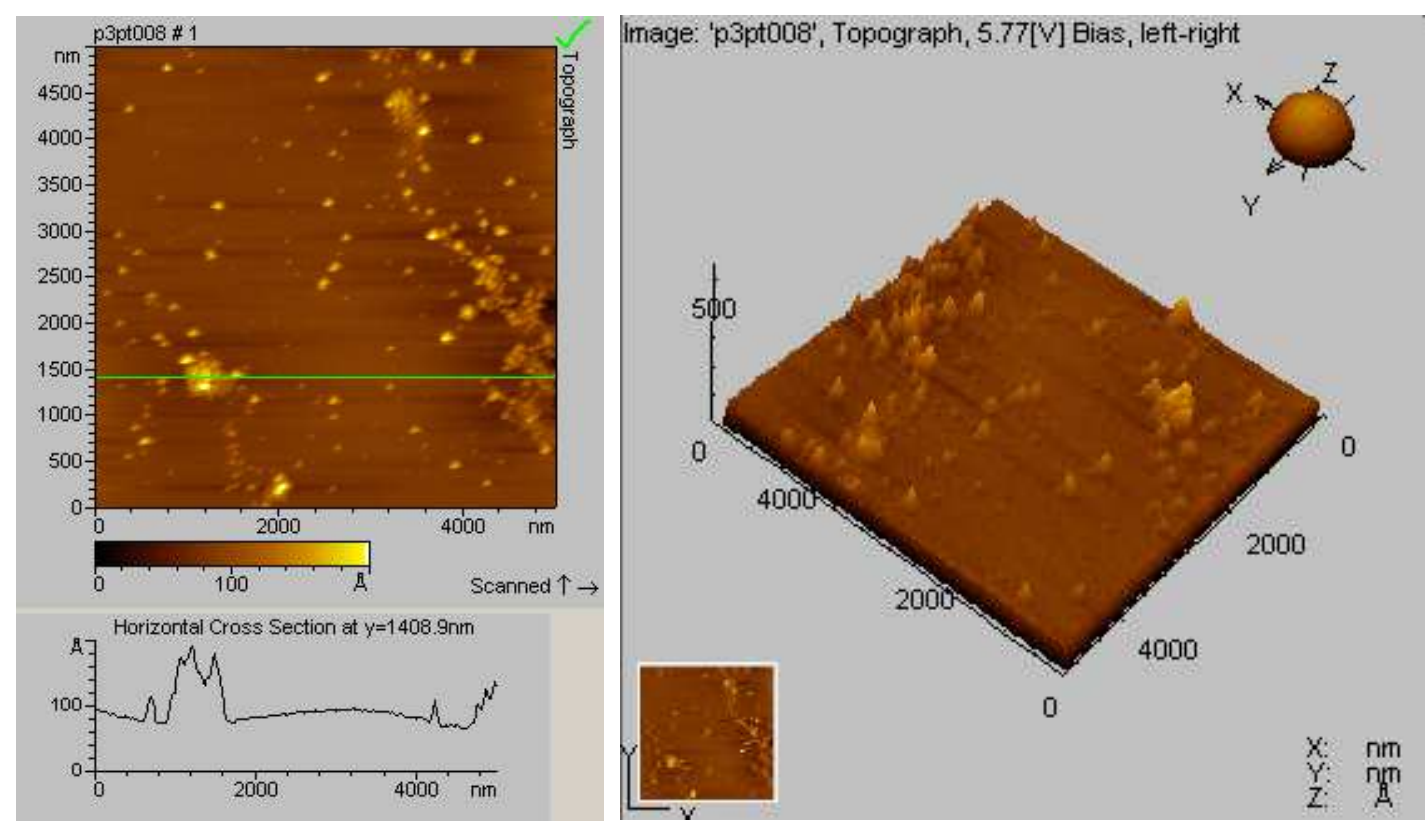

Figura 3.52: Imagem SPM $(5 \times 5 \mu \mathrm{m})$ no modo contato intermitente do filme de 3TPtTPyP/CuPcTS depositado sobre mica. 


\section{Capítulo 4}

\section{Considerações finais}

As novas porfirinas polinucleares de platina(II) obtidas neste trabalho se mostraram bastante interessantes do ponto de vista supramolecular.

Frente aos objetivos propostos no início deste trabalho, entende-se que eles foram atendidos, uma vez que as duas novas supermoléculas de platina(II) associadas a tetrapiridilporfirinas foram sintetizadas, plenamente caracterizadas e estudadas em termos de suas propriedades eletroquímicas, espectroscópicas e na preparação de arranjos supramoleculares onde elas se comportam como unidades precursoras.

A variação na geometria das supermoléculas revelou-se um aspecto em nada trivial, o que ficou claramente demonstrado no estudo dos filmes por SPM e na interação destas espécies com biomoléculas, mais especificamente DNA. Nos resultados de espectroscopia eletrônica o isômero para mostrou sempre um caráter maior de acoplamento eletrônico entre as unidades cromóforas platina-porfirina. O processo de transferência de elétrons na redução eletroquímica do anel porfirínico também ficou sujeito a variações em função da geometria da supermolécula.

Os dados dos cálculos teóricos, especialmente a geometria prevista por mecânica molecular, se mostraram extremamente úteis na interpretação dos resultados experimentais, e obteve-se dados coerentes entre essas duas abordagens. Todos os resultados experimentais se mostraram consistentes com as estruturas propostas. 
Os arranjos espaciais adotados permitem a exploração de diferentes aplicações para estas supermoléculas, onde o isômero para se mostra viável na preparação de filmes altamente homogêneos e ricos em nanoestruturas. A configuração tipo cela adotada pelo isômero meta o torna um virtual candidato para atuar como um "clipe molecular" em dispositivos funcionais. Pode-se explorar nesse sentido a associação deste isômero com espécies como nanotubos de carbono e moléculas de fulereno.

Em relação ao estudo de propriedades, permanece em aberto a investigação das propriedades fotofísicas e fotoquímicas das supermolécuas, principalmente em estado sólido e em soluções vítreas a baixa temperatura. Nesse aspecto, o complexo com $[\mathrm{Pt}(\text { terpy }) \mathrm{Cl}]^{+}$se mostra mais promissor para exibir perfis de emissão intenso em estado sólido, tendo em vista o que já foi reportado na literatura.

Sobre uma potencial aplicação destas espécies em terapia fotodinâmica, os estudos fotofísicos atuam como um pré-requisito. Trabalhos previamente publicados levantam a hipótese de se ter um sistema que conjugue a atividade citostática do complexo de platina(II) com a atividade fotodinâmica da porfirina. Porém, o provável efeito supressor que o complexo de platina(II) deve ter sobre a emissão da porfirina em solução pode funcionar como um fator limitante desta atividade. Por outro lado, é bem estabelecido que a atividade de compostos em PDT é firmemente relacionada com a habilidade dos mesmos em interagir com membranas celulares e biomoléculas como a cadeia de DNA. Neste aspecto, os resultados obtidos neste trabalho se mostram favoráveis para essa aplicação.

Os dois isômeros revelaram padrões de interação diferentes com DNA, e os filmes obtidos por auto-montagem hierárquica são fortes candidatos para atuarem como sensores híbridos na modificação química de eletrodos.

A interpretação dada para os resultados de microscopia de varredura por sonda está em consonância com o que se tem visto até o momento em termos de arranjos supramoleculares obtidos por auto-montagem e auto-montagem hierárquica. Esses perfis de nanoestruturas coincidem também com os padrões observados para sistemas 
porfirínicos polinucleares de rutênio. Contudo, provas indubitáveis para os modelos organizacionais propostos ainda não puderam ser obtidas. Este é, inclusive, um dos maiores desafios na interpretação dos resultados de microscopia de força atômica.

Novas supermoléculas de tetrapiridilporfirinas coordenadas a outros complexos diimínicos de platina(II) estão ainda em estudo, mas a rota sintética e a caracterização parcial já foram estabelecidas, conforme apresentado nos apêndices. 


\section{Referências Bibliográficas}

[1] Toma, H. E. J. Braz. Chem. Soc. 2003, 14, 845-869.

[2] http://www.er.doe.gov/production/bes. fev-2006.

[3] Soi, A.; Hirsch, A. Adv. Mater. 1999, pages 1337-1339.

[4] Lehn, J.-M. Science 2002, 295, 2400-2403.

[5] Fenniri, H.; Mathivanan, P.; Vidale, K. L.; Sherman, D. M.; Hallenga, K.; Wood, K. V.; Stowell, J. G. J. Am. Chem. Soc. 2002, 124, 11064.

[6] Elemans, J. A. A. W.; Rowan, A. E.; Nolte, R. J. M. J. Mater. Chem. 2003, 13, 2661-2670.

[7] Alstrum-Acevedo, J. H.; Brennaman, M. K.; Meyer, T. J. Inorg. Chem. 2005, $44,6802-6827$.

[8] Zouni, A.; Witt, H.-T.; Kern, J.; Fromme, P.; Krau, N.; Saenger, W.; Orth, P. Nature 2001, 409, 739-743.

[9] Steinberg-Yfrach, G.; Rigaud, J. L.; Durantini, E. N.; Moore, A. L.; Gust, D.; Moore, T. A. Nature 1998, 392, 479.

[10] Nogueira, A. F.; Furtado, L. F. O.; Formiga, A. L. B.; Nakamura, M.; Araki, K.; Toma, H. E. Inorg. Chem 2004, 43, 396-398.

[11] Textor, M.; Oswald, H. R. Z. Anorg. Allg. Chem. 1974, 407, 244-256. 
[12] Connick, W. B.; Henling, R. E. M. L. M.; Marsh, R. E.; Gray, H. B. Inorg. Chem. 1996, 35, 6261-6265.

[13] Lehn, J.-M.; Drain, C. M. J. Chem. Soc., Chem. Commun. 1994, pages 23132315.

[14] Damos, F. S.; Mendes, R. K.; Kubota, L. T. Quim. Nova 2004, 27, 970-979.

[15] Werner, A. Zeits. Anorg. Chem. 1893, 3, 267.

[16] http://nobelprize.org/chemistry/laureates/1987/index.html. abr-2006.

[17] Lehn, J.-M. Angew. Chem. Int. Ed. 1988, $27,89$.

[18] Lehn, J.-M. Supramolecular Chemistry, Concepts and Perspectives; Wiley-VCH: Weinheim, New York, 1995.

[19] Vögtler, F. Supramolecular Chemistry; Jonh Wiley: Chicheste, 1995.

[20] Atwood, J. L.; Davies, J. E. D.; MacNicol, D. D.; Vögtle, F.; Lehn, J.-M.; Eds.. Comprehensive Supramolecular Chemistry; Pergamon: Oxford, 1996.

[21] Lehn, J.-M. Proc. Natl. Acad. Sci. 2002, 99, 4763-4768.

[22] Toma, H. E. An. Acad. Bras. Ci 2000, 72, 1.

[23] Pease, A. R.; Jeppensen, J. O.; Stoddart, J. F.; Luo, Y.; Collier, C. P.; Heath, J. R. Acc. Chem. Res. 2001, 34, 433-444.

[24] Balzani, V.; Venturi, M.; Credi, A. Molecular Devices and Machines: A Journey into the Nanoworld; Wiley-VCH: Weinheim, 2004.

[25] Balzani, V.; Credi, A.; Venturi, M. Coord. Chem. Rev. 1998, 171, 3-16.

[26] Lehn, J.-M. Science 2002, 295, 2400-2403.

[27] Whitesides, G. M.; Grzybowski, B. Science 2002, 295, 2418-2421. 
[28] Bonifácio, L. S.; Anaissi, F. J.; Toma, H. E. Quim. Nova 2005, 28, 897-900.

[29] http://www.intel.com/technology/silicon/mooreslaw/. fev-2006.

[30] Carter, F. L.; Siatkowsky, R. E.; (Eds), H. W. Molecular Electronic Devices; North Holland: Amsterdam: The Netherlands, 1988.

[31] Lindsey, J. S. New J. Chem 1991, 15, 153-180.

[32] Drexler, K. E. Nanosystems: Molecular Machinery, Manufacturing and Computation; Wiley: New York, 1992.

[33] Bard, J. A. Integrated Chemical Systems: A Chemical Approach to Nanotechnology; Wiley: New York, 1994.

[34] Alivisatos, A. P.; Barbara, P. F.; Castleman, A. W.; Chang, J.; Dixon, D. A.; Klein, M. L.; McLendon, G.; Miller, J. S.; Ratner, M. A.; Rossky, P. J.; Stupp, S. I.; Thompson, M. E. Adv. Mater. 1998, 10, 1297-1336.

[35] Balzani, V.; Credi, A.; Raymo, F. M.; Stoddart, J. F. Angew. Chem. Int. Ed. 2000, 39, 3348-3391.

[36] Service, R. F. Science 2002, 295, 2398-2399.

[37] Reinhoudt, D. N.; Crego-Calama, M. Science 2002, 295, 2403-2407.

[38] Toma, H. E. O Mundo Nanométrico: a dimensão do novo mundo; Oficina de Textos: São Paulo, 2004.

[39] Service, R. F. Science 2005, 309, 95.

[40] Balzani, V.; Juris, A.; Venturi, M.; Campagna, S.; Serroni, S. Chem. Rev. 1996, 96, 759-833.

[41] Toma, H. E.; Araki, K. Quim. Nova 2002, 25, 962-975. 
[42] Balzani, V.; Moggi, L.; Scandola, F. Towards a supramolecular photochemistry: assembly of molecular components to obtain photochemical molecular devices. in: V. Balzani (Ed.). Supramolecular Photochemistry. p. 1.; 1987.

[43] da Silva, J. J. R. F.; Willians, R. J. P. The Biological Chemistry of the Elements - The Inorganic Chemistry of Life; Oxford: Oxford, 1991.

[44] Kaim, W.; Schwederski, B. Bioinorganic Chemistry: Inorganig Chemistry in the Chemistry of Life. An Introduction and Guide; John Wiley e Sons: New York, 1994.

[45] Marcus, R. A. Rev. Mod. Phys. 1993, 65, 599-610.

[46] Krueger, J. S.; Mayer, J. E.; Mallouk, T. E. J. Am. Chem. Soc. 1988, 110, 8232.

[47] Meyer, T. J. Acc. Chem. Res. 1989, 22, 163-170.

[48] Gust, D.; Moore, T. A.; Moore, A. L.; Lee, S. J.; Bittersmann, E.; Luttrull, D. K.; Rehms, A. A.; DeGraziano, J. M.; Ma, X. C.; Gao, F.; Belford, R. E.; Trier, T. T. Science 1990, 248, 199.

[49] Baxter, S. M.; Jones, J.; Danielson, E.; Worl, L.; Strouse, G.; Younathan, J.; Meyer, T. J. Coord. Chem. Rev. 1991, 47, 111.

[50] Jones, J.; Baxter, S. M.; Strouse, G. F.; Meyer, T. J. J. Am. Chem. Soc. 1993, $115,7363$.

[51] Yonemoto, E. H.; Saupe, G. B.; Schmehl, R. H.; Hubig, S. M.; Riley, R. L.; Iverson, B. L.; Mallouk, T. E. J. Am. Chem. Soc. 1994, 116, 4786.

[52] Bard, A. J.; Fox, M. A. Acc. Chem. Res. 1995, 28, 141.

[53] Yagi, M.; Kaneko, M. Chem. Rev 2001, 101, 21-35.

[54] Sun, L.; Hammarström, L.; Akermarka, B.; Styringc, S. Chem. Soc. Rev. 2001, 30, 36-49. 
[55] Imahori, H.; Mori, Y.; Matano, Y. J. Photochem. Photobiol. C Photochem. Rev. 2003, 4, 5183.

[56] Chakraborty, S.; Wadas, T. J.; Hester, H.; Schmehl, R.; Eisenberg, R. Inorg. Chem. 2005, 44, 6865-6878.

[57] Williams, A. F.; Floriani, C.; Merbach, A. E.; Eds.. Perspectives in Coordination Chemistry; VCH: Basel: Switzerland, 1992.

[58] Toma, H. E.; Araki, K. Coord. Chem. Rev. 2000, 196, 307.

[59] Bignozzi, C. A.; Argazzi, R.; Chiorboli, C.; Scandola, F.; .; Dyer, R. B.; Schoonover, J. R.; Meyer, T. J. Inorg. Chem 1994, 33, 1652.

[60] Dovidauskas, S.; Toma, H. E.; Araki, K.; Sacco, H.; Iamamoto, Y. Inorg. Chim. Acta 2000, 305, 206.

[61] Denti, G.; Campagna, S.; Serroni, S.; Ciano, M.; Balzani, V. J. Am. Chem. Soc. 1992, 114, 2944.

[62] Silva, E. O.; Araki, K.; Toma, H. E. Monatshefte Fur Chemie 1998, 129, 975-984.

[63] Balzani, V.; Scandola, F. Ellis Horwood: Chichester 1991.

[64] Balzani, V. Tetrahedron 1992, 48, 10443.

[65] Robin, M. B.; Day, P. Adv. Inorg. Chem. Radiochem. 1967, 10, 247.

[66] Hush, N. S. Prog. Inorg. Chem. 1967, 8, 391.

[67] (Ed.), D. D. The Porphyrins; Academic: New York, 1978.

[68] Toma, H. E.; Araki, K. J. Chem. Research 1990, pages 82-83.

[69] Toma, H. E. Quim. Nova 1991, 14, 189-195.

[70] Toma, H. E.; Araki, K. J. Electroanal. Chem. 1991, 297, 301-307. 
[71] Toma, H. E.; Araki, K. J. Coord. Chem. 1993, 30, 9-17.

[72] Toma, H. E.; Araki, K. J. Chem. Res.-S 1994, 7, 290.

[73] Toma, H. E.; Araki, K. J. Photochem. Photobiol. A-Chem. 1994, 83, 245-250.

[74] Araki, K.; Santos, P. S.; de Oliveira, L. F. C.; Toma, H. E. Spectr. Letters 1995, 28, 119-126.

[75] Araki, K.; Angnes, L.; Azevedo, C. M. N.; Toma, H. E. J. Electroanal. Chem. 1995, 397, 205-210.

[76] Araki, K.; Wagner, M. J.; Wrigton, M. S. Langmuir 1996, 12, 5393-5398.

[77] Onuki, J.; Medeiros, M. H. G.; Araki, K.; Toma, H. E.; Catalani, L. H.; di Macio, P. Photochem. Photobiol. 1996, 63, 272-277.

[78] Angnes, L.; Azevedo, C. M. N.; Araki, K.; Toma, H. E. Anal. Chim. Acta 1996, 329, 91-96.

[79] Azevedo, C. M. N.; Araki, K.; Angnes, L.; Toma, H. E. Electroanalysis 1998, 10, $467-471$.

[80] Araki, K.; Araújo, A. L.; Toyama, M. M.; Franco, M.; Azevedo, C. M. N.; Angnes, L.; Toma, H. E. J. Porph. Phthal. 1998, 2, 467-472.

[81] Toyama, M. M.; Franco, M.; Catalani, L. H.; Araki, K.; Toma, H. E. J. Photochem. Photobiol. 1998, 118, 11-17.

[82] Ravanat, J.-L.; Cadet, J.; Araki, K.; Toma, H. E.; Medeiros, M. H. G.; Mascio, P. D. Photochem. Photobiol. 1998, 68, 698-702.

[83] Azevedo, C. M. N.; Araki, K.; Toma, H. E.; Angnes, L. Anal. Chim. Acta 1999, $387,175-180$. 
[84] Araki, K.; Silva, C. A.; Toma, H. E.; Catalani, L. H.; Medeiros, M. H. G.; Mascio, P. J. D. J. Inorg. Biochem. 2000, 78, 269.

[85] Dovidauskas, S.; Araki, K.; Toma, H. E. J. Porph. Phthal. 2000, 4, 727.

[86] Toyama, M. M.; Demets, G. J. F.; Araki, K.; Toma, H. E. Electrochem. Commun. 2000, 2, 749 .

[87] Araki, K.; Lima, S. S.; Winnischofer, H. An. Acad. Bras. Ciências 2000, 72, 1-6.

[88] Toma, H. E.; Araki, K. J. Phothochem. Photobiol. A: Chem. 2001, 142, 25-30.

[89] Araki, K.; Dovidauskas, S.; Winnischofer, H.; Alexiou, A. D. P.; Toma, H. E. J. Electroanal. Chem. 2001, 498, 152.

[90] da Rocha, J. R. C.; Demets, G. J. F.; Bertotti, M.; Araki, K.; Toma, H. E. J. Electroanal. Chem. 2002, 526, 69-76.

[91] Engelmann, F. M.; Losco, P.; Winnischofer, H.; Araki, K.; Toma, H. E. J. Porph. Phthal. 2002, 6, 33.

[92] Winnischofer, H.; Dovidauskas, S.; Nakamura, M.; Toma, H. E.; Araki, K. Electrochim. Acta 2004, 49, 3711-3718.

[93] da Rocha, J. R. C.; Bertotti, M.; Angnes, L.; Araki, K.; Toma, H. E. Anal. Chim. Acta 2002, 452, 23-28.

[94] Nogueira, A. F.; Formiga, A. L. B.; Winnischofer, H.; Nakamura, M.; Engelmann, F. M.; Araki, K.; E.Toma, H. Photochem. Photobio. Sci 2004, 3, 56.

[95] Araki, K.; Winnischofer, H.; Viana, H. E. B.; Toyama, M. M.; Engelmann, F. M.; Mayer, I.; Formiga, A. L. B.; Toma, H. E. J. Electroanal. Chem. 2004, 562, 145.

[96] Winnischofer, H.; Otake, V. Y.; Dovidauskas, S.; Nakamura, M.; Toma, H. E.; Araki, K. Electrochim. Acta 2004, 49, 3711-3718. 
[97] Nunes, G. S.; Mayer, I.; Toma, H. E.; Araki, K. J. Catalysis 2005, 236, 5561.

[98] Mayer, I.; Formiga, A. L. B.; Engelmann, F. M.; Winnischofer, H.; Oliveira, P. V.; Tomazela, D. M.; Eberlin, M. N.; Toma, H. E.; Araki, K. Inorg. Chim. Acta 2005, 358, 2629.

[99] Mayer, I.; Eberlin, M.; Tomazela, D. M.; Toma, H. E.; Araki, K. J. Braz. Chem. Soc. 2005, 16, 418-425.

[100] Kolesar, E. S.; Wiseman, J. M. J. Anal. Chem. 1989, 61, 2355.

[101] Malinski, T.; Taha, Z. Nature 1992, 358, 676.

[102] Lefevre, D.; Porteu, F.; Balog, P.; Roulliay, M.; Zalczer, G.; Palacin, S. Langmuir 1993, 9, 150.

[103] Shi, C.; Anson, F. C. Inorg. Chim. Acta 1994, 215, 225.

[104] Araki, K.; Angnes, L.; Toma, H. E. Adv. Mater. 1995, 7, 554-558.

[105] Wasielewski, M. R. Chem. Rev. 1992, 92, 435-461.

[106] Collman, J. P.; Denisevich, P.; Konai, Y.; Marrocco, M.; Koval, C.; Anson, F. C. J. Am. Chem. Soc. 1980, 102, 6027.

[107] Araki, K.; Toma, H. E. Inorg. Chim. Acta 1991, 179, 293-296.

[108] Steiger, B.; Shi, C.; Anson, F. C. Inorg. Chem. 1993, 32, 2107.

[109] Bedioui, F.; Devynck, J.; Bied-Charreton, C. J. Mol. Catal. A: Chem. 1996, 113, $3-11$.

[110] Shi, C.; Anson, F. C. Inorg. Chem. 1996, 35, 7928-7931.

[111] Steiger, B.; Anson, F. C. Inorg. Chem. 1994, 33, 5767.

[112] Gunter, M. J.; Turner, P. Coord. Chem. Rev. 1991, 108, 115. 
[113] Meunier, B. Chem. Rev. 1992, 92, 1411.

[114] Winnischofer, H.; Formiga, A. L. B.; Nakamura, M.; Toma, H. E.; Araki, K.; Nogueira, A. F. Photochem. Photobiol. Sci. 2005, 4, 359-366.

[115] Milic, T. N.; Chi, N.; Yablon, D.; Flynn, G. W.; Batteas, J. D.; Drain, C. M. Angew. Chem. Int. Ed. 2002, 41, 2117.

[116] Ojadi, E.; Selzer, R.; Linschitz, H. J. Am. Chem. Soc. 1985, 107, 7783-7784.

[117] Ribeiro, M. G.; Azzellini, G. C. J. Braz. Chem. Soc. 2003, 14, 914-921.

[118] Honeybourne, C. L. J. J. Phys. Chem. Solids 1987, 48, 109.

[119] Yanagi, H.; Kouzeki, T.; Ashida, M. J. Appl. Phys. 1993, 73, 3812.

[120] Yanagi, H.; Kanbayashi, Y.; Sclettwein, D.; Wohrle, D.; Armstrong, N. R. J. Appl. Phys. 1994, 98, 4760.

[121] Bonnett, R.; Ioannou, S.; James, A. G.; Pitt, C. W.; Soe, M. M. Z. J. Mater. Chem. 1992, 2, 823.

[122] Liu, J.; Chen, T.; Xu, L.; Shen, S.; Zhou, Q.; Liu, K.; Jiang, L.; Xu, H. J. Photochem. Photobiol. A 1993, 76, 91.

[123] Bonosi, F.; Ricciardi, G.; Lelj, F. Thin Solid Films 1994, 243, 310.

[124] Kampas, F. J.; Yamashita, K.; Fajer, J. Nature 1980, 284, 40.

[125] Bedioui, F.; Devynck, J.; Bied-Charreton, C. Acc. Chem. Res. 1995, 28, 30.

[126] Curran, D.; Crimshaw, J.; Perera, S. D. Chem. Soc. Rev. 1991, 20, 391.

[127] Quintino, M. D. S. M.; Winnischofer, H.; Nakamura, M.; Araki, K.; Toma, H. E.; Angnes, L. Anal. Chim. Acta 2005, 539, 215-222.

[128] Lipskier, J. F.; Thi, T.-H. T. Inorg. Chem. 1993, 32, 722-731. 
[129] Thi, T.-H. T. Coord. Chem. Rev. 1997, 160, 53-91.

[130] Schneider, H.-J.; Wang, M. J. Org. Chem. 1994, 59, 7464-7472.

[131] Savenije, T. J.; Koehorst, R. B. M.; Schaafsma, T. J. Chem. Phys. Let. 1995, $244,363-370$.

[132] Schaafsmaa, T. J.; Savenijea, T. J.; Koehorst, R. B. M.; Vergeldt, F. J.; Wienke, J. J. Lumin. 1997, 72-74, 81-82.

[133] Mayer, I. Obtenção e Propriedades de meso-Tetra(piridil)porfirinas Supramoleculares e dos Nanomaterias Obtidos por Montagem Eletrostática Camada por Camada PhD thesis, Instituto de Química, Universidade de São Paulo, 2005.

[134] Rosenberg, B.; Vancamp, L.; Trosko, J. E.; Mansour, V. H. Nature 1969, 222, 385.

[135] Pratt, W. B.; Ruddon, R. W.; Ensminger, W. D.; Maybaum, J. The Anticancer Drugs; Oxford University Press: New York, second ed., 1994.

[136] Hofmann, A.; Jaganyi, D.; Munro, O. Q.; Liehr, G.; van Eldik, R. Inorg. Chem. 2003, 42, 1688-1700.

[137] Shermann, S. E.; Lippard, S. J. Chem. Rev. 1987, 87, 1153-1181.

[138] Sundquist, W. I.; Lippard, S. J. Coord. Chem. Rev. 1990, 100, 293-322.

[139] Weiss, R. B.; Christian, M. C. Drugs 1993, 46, 360-377.

[140] Wong, E.; Giandomenico, C. M. Chem. Rev. 1999, 99, 2451-2466.

[141] Lu, W.; Vicic, D. A.; Barton, J. K. Inorg. Chem. 2005, 44, 7970-7980.

[142] S. van Zutphen, J. R. Coord. Chem. Rev. 2005, 249, 2845.

[143] Goodisman, J.; Hagrman, D.; Tacka, K. A.; Souid, A.-K. Cancer Chemother. Pharmacol. 2006, 57, 257. 
[144] Brunner, H.; Schellerer, K.-M. Inorg. Chim. Acta 2003, 350, 39-48.

[145] Brunner, H.; Arndt, M. R.; Treittinger, B. Inorg. Chim. Acta 2004, 357, 1649.

[146] W.Jennette, K.; Lippard, S. J.; Vassiliades, G. A.; Bauer, W. R. Proc. Natl. Acad. Sci. 1974, 71, 3839.

[147] Constable, E. C. Adv. Inorg. Chem. Radiochem. 1986, 30, 69.

[148] Takahara, P. M.; Frederick, C. A.; Lippard, S. J. J. Am. Chem. Soc. 1996, 118, $12309-12321$.

[149] Sherman, S. E.; Gibson, D.; Wang, A. H.-J.; Lippard, S. J. Science 1985, 230, 412.

[150] Cusumano, M.; Pietro, M. L. D.; Giannetto, A. Inorg. Chem. 2006, 45, 230-235.

[151] Barton, J. K.; Lippard, S. J. Met. Ions Biol. 1980, 1, 31.

[152] Erkkila, K. E.; Odom, D. T.; Barton, J. K. Chem. Rev. 1999, 99, 2777-2795.

[153] Cortes, M.; Carney, J. T.; Oppenheimer, J. D.; Downey, K. E.; Cummings, S. D. Inorg. Chim. Acta 2002, 333, 148-151.

[154] Peyratout, C. S.; Aldridge, T. K.; Crites, D. K.; McMillin, D. R. Inorg. Chem. $1995,34,4484$.

[155] Bailey, J. A.; Miskowski, V. M.; Gray, H. B. Inorg. Chem. 1993, 32, 369-370.

[156] McMillin, D. R.; Moore, J. J. Coord. Chem. Rev. 2002, 229, 113-121.

[157] Hobert, S. E.; Carney, J. T.; Cummings, S. D. Inorg. Chim. Acta 2001, 318, $89-96$.

[158] Connick, W. B.; Geiger, D.; Eisenberg, R. Inorg. Chem. 1999, 38, 3264.

[159] Krüger, H.; van Eldik, R. J. Chem. Soc., Chem. Commun. 1990, page 330. 
[160] Yang, Q.-Z.; Whu, L.-W.; Wu, Z.-X.; Zhang, L.-P.; Tung, C.-H. Inorg. Chem. 2002, 41, 5653-5655.

[161] Aldridge, T. K.; Stacy, E. M.; McMillin, D. R. Inorg. Chem. 1994, 33, 722-727.

[162] Yip, H.-K.; Cheng, L.-K.; Cheung, K.-K.; Che, C.-M. J. Chem. Soc. Dalton Trans. 1993, pages 2933-2938.

[163] Hissler, M.; McGarrah, J. E.; Connick, W. B.; Geiger, D. K.; Cummings, S. D.; Eisenberg, R. Coord. Chem. Rev. 2000, 208, 115-137.

[164] Miskowski, V. M.; Houlding, V. H. Inorg. Chem. 1989, 28, 1529-1533.

[165] Houlding, V. H.; Miskowski, V. M. Coord. Chem. Rev. 1991, 111, 145-152.

[166] Bailey, J. A.; Hill, M. G.; Marsh, R. E.; Miskowski, V. M.; Schaefe, W. P.; Gray, H. B. Inorg.Chem. 1995, 34, 4591-4599.

[167] Stang, P. J.; Olenyuk, B. Acc. Chem. Res. 1997, 30, 502-518.

[168] Fujita, M.; Sasaki, O.; Mitsuhashi, T.; Fujita, T.; Yazaki, J.; Yamaguchi, K.; Ogura, K. J. Chem. Soc., Chem. Commun. 1996, page 1535.

[169] Stang, P. J.; Olenyuk, B.; Fan, J.; Arif, A. M. Organometallics 1996, 15, 904.

[170] Stang, P. J.; Persky, N. E.; Manna, J. J. Am. chem. Soc. 1997, 119, 4777.

[171] Islam, A.; Sugihara, H.; Hara, K.; Singh, L. P.; Katoh, R.; Yanagida, M.; Takahashi, Y.; Murata, S.; Arakawa, H. New J. Chem. 2000, 24, 343-345.

[172] Islam, A.; Sugihara, H.; Hara, K.; Singh, L. P.; Katoh, R.; Yanagida, M.; Takahashi, Y.; Murata, S.; Arakawa, H.; Fujiihashi, G. Inorg. Chem. 2001, 40, $5371-5380$.

[173] Yang, Q.-Z.; Whu, L.-W.; Wu, Z.-X.; Zhang, H.; Chen, B.; Zhang, L.-P.; Tung, C.-H. Inorg. Chem. 2004, 43, 5195-5197. 
[174] Samba, H.; Armond, M. K. D. Coord. Chem. Rev. 1991, 111, 73-81.

[175] Drain, C. M.; Vasenko, A.; Batteas, J. D. Angew. Chem. Int. Ed. 1998, 37, $2344-2347$.

[176] Drain, C. M. Proc. Natl. Acad. Sci. 2002, 99, 5178-5182.

[177] Drain, C. M.; Batteas, J. D.; Flynn, G. W.; Milic, T.; Chi, N.; Yablon, D. G.; Sommers, H. Proc. Natl. Acad. Sci. 2002, 99, 6498-6502.

[178] Stang, P. J.; Fan, J.; Olenyuk, B. Chem. Commun. 1997, pages 1453-1454.

[179] Fan, J.; Whiteford, J. A.; Olenyuk, B.; Levin, M. D.; Stang, P. J.; Fleischer, E. B. J. Amer. Chem. Soc. 1999, 121, 2741-2752.

[180] Yuan, H.; Thomas, L.; Woo, L. K. Inorg. Chem. 1996, 35, 2808-2817.

[181] Pasternack, R. F.; Garrity, P.; Ehrlich, B.; Davis, C. B.; Gibbs, E. J.; Orloff, G.; Giartosio, A.; Turano, C. Nucleic Acids Res. 1986, 14, 5919.

[182] Munson, B. R.; Fiel, R. J. Nucleic Acids Res. 1980, 8, 2835-2842.

[183] Munson, B. R.; Fiel, R. J. Nucleic Acids Res. 1992, 20, 1315-1319.

[184] Pasternack, R. F.; Gibbs, E. J.; Villafranca, J. J. Biochemistry 1983, 22, 24062414.

[185] Sternberg, E.; Dolphin, D.; Bruckner, C. Tetrahedron 1998, 54, 4151-4202.

[186] Henderson, B. W.; Dougherty, T. J. Photochem. Photobiol. 1992, 55, 145-157.

[187] Dougherty, T. J.; Gomer, C. J.; Henderson, B. W. J. Natl. Cancer Inst. 1998, 90, 889-905.

[188] Song, R.; Kim, Y.-S.; Leed, C. O.; Sohn, Y. S. Tetrahedron Letters 2003, 44, 15371540. 
[189] Song, R.; Kimb, Y.-S.; Sohna, Y. S. J. Inorg. Biochem. 2002, 83, 8388.

[190] Munakata, H.; Kanzaki, T.; Nakagawa, S.; Imai, H.; Uemori, Y. Chem. Pharm. Bull. 2001, 49, 1573.

[191] Munakata, H.; Imai, H.; Nakagawa, S.; Osada, A.; Uemori, Y. Chem. Pharm. Bull. 2003, 51, 614 .

[192] Chan, W. S.; Marshall, J. F.; Lam, G. Y. F.; Hart, I. R. Cancer Res. 1988, 48, 3040.

[193] Tronconi, M.; Colombo, A.; Cesare, M. D.; Marchesini, R.; Woodburn, K. W.; Reiss, J. A.; Phillips, D. R.; Zunino, F. Cancer Lett. 1995, 88, 41.

[194] Allison, B. A.; Waterfield, E.; Richter, A. M.; Levy, J. G. Photochem. Photobiol. 1991, 54, 709-715.

[195] Lottnera, C.; Knuechelc, R.; Bernhardtd, G.; Brunner, H. Cancer Letters 2004, 215, 167177.

[196] Brunner, H.; Gruber, N. Inorg. Chim. Acta 2004, 357, 4423.

[197] Bernhardt, G.; Brunner, H.; Gruber, N.; Lottner, C.; Pushpan, S. K.; Tsuno, T.; Zabel, M. Inorg. Chim. Acta 2004, 357, 44524466.

[198] Grätzel, M.; Kalianasundaran, K. Coord. Chem. Rev. 1998, 177, 347-414.

[199] Morgan, G.; Burstall, F. H. J. Chem. Soc. 1934, page 965.

[200] Adler, A. D.; Longo, F. R.; Finarell, J.; Goldmach, J.; Assour, J.; Korsakof, L. J. of Org. Chem. 1967, 32, 476.

[201] Fleischer, E. B.; Shachter, A. M. Inorg. Chem. 1991, 30, 3763-3769.

[202] Job, P. Ann. Chim. 1928, 9, 113-199.

[203] Hill, Z. D.; MacCarthy, P. J. Chem. Educ. 1986, 63, 162-167. 
[204] Allinger, N. L. J. Am. Chem. Soc. 1977, 99, 8127.

[205] Formiga, A. L. B. Estudo Teórico e Experimental de Estruturas Supramoleculares Obtidas com Clusters Trinucleares de Rutênio e Porfirinas PhD thesis, Instituto de Química, Universidade de São Paulo, 2005.

[206] Hypercube inc. Gainesville.; FL.; USA. 2002.

[207] Schmidt, M. W.; Baldridge, K. K.; Boatz, J. A.; Elbert, S. T.; Gordon, M. S.; Jensen, J. H.; Koseki, S.; Matsunaga, N.; Nguyen, K. A.; Su, S.; Windus, T. L.; Dupuis, M.; Jr, J. A. M. J. Comp. Chem. 1993, 14, 1347-1363.

[208] Tomazela, D. M.; Gozzo, F. C.; Mayer, I.; Engelmann, F. M.; Araki, K.; Toma, H. E.; Eberlin, M. N. J. Mass Spectrometry 2004, 39, 1161.

[209] Eberlin, M. N. J. Mass Spectrom. 2006, 41, 141.

[210] Hoffmann, E. J. Mass Spectrom. 1996, 31, 129-137.

[211] Pregosin(ed.), P. S. Transition Metal Nuclear Magnetic Resonance; 1991.

[212] von Zelewsky, A. Helv. Chim. Acta 1968, 51, 802.

[213] Pidcock, A.; Richards, R. E.; Venanzi, L. M. J. Chem. Soc. A 1968, page 1970.

[214] Nakamoto, K. Infrared and Raman Spectra of Inorganic and Coordination Compounds; John Wiley \& Sons: New York, 4 ed., 1986.

[215] Silverstein.; Bassler.; Morril. Identificação Espectrométrica de compostos orgânicos; Guanabara-Koogan: Rio de Janeiro, 5 ed., 1994.

[216] Ould-Moussa, L.; Castella-Ventura, M.; Kassab, E.; Poizat, O.; Strommen, D. P.; Kincaid, J. R. J. Raman Spectrosc. 2000, 31, 377-390.

[217] http://journals.iucr.org/. mai-2006.

[218] Gouterman, M. J. Mol. Spectrosc. 1961, 6, 138-163. 
[219] Spellane, P. J.; Gouterman, M.; Antipas, A.; Kim, S.; Liu, Y. C. Inorg. Chem. 1980, 19, 386 .

[220] Yang, L.; Wimmer, F. L.; Wimmer, S.; Zhao, J.; Braterman, P. S. J. Organomet. Chem. 1996, 525, 1-8.

[221] Collison, D.; Mabbs, F. E.; McInnes, E. J. L.; Taylor, K. J.; Welch, A. L.; Yellowlees, L. J. J. Chem. Soc. Dalton Trans. 1996, pages 329-334.

[222] Braterman, P. S.; Song, J.-I.; Wimmer, F. M.; Wimmer, S.; Kaim, W.; Klein, A.; Peacock, R. D. Inorg. Chem. 1992, 31, 5084-5088.

[223] Araki, K. PiridilPorfirinas Supermoleculares Como Interfaces Eletroquímica e Fotoquímica, Tese de Livre Docência $\mathrm{PhD}$ thesis, Instituto de Química, Universidade de São Paulo, 2000.

[224] Brown, A. R.; Guo, Z.; Mosselmans, F. W. J.; Parsons, S.; Schroder, M.; Yellowlees, L. J. J. Am. Chem. Soc. 1999, 120, 8805-8811.

[225] Winnischofer, H. Interfaces e Dispositivos Baseados em Porfirinas Supramoleculares PhD thesis, Instituto de Química, Universidade de São Paulo, 2005.

[226] Dovidauskas, S. Química Supramolecular de Porfirino-Clusters PhD thesis, Instituto de Química, Universidade de São Paulo, 2001.

[227] de Carvalho, R. M.; R., S.; Kubota, L. T. Quim. Nova 2003, 26, 97-104.

[228] Malmborg, A.-C.; Michaelsson, A.; Ohlin, M.; Jansson, B.; Borreback, C. A. K. J. Immunol. 1992, 35, 643-650.

[229] Fagerstam, L. G.; Frostell-Karlsson, A.; Karlsson, R.; Persson, B.; Ronnberg, I. J. Chromatogr. 1992, 597, 397-410.

[230] Morton, T. A.; Myska, D. G.; Chaiken, I. Anal. Biochem. 1995, 227, 176-185.

[231] Manual do equipamento autolab springle. 
[232] Karlsson, R.; Michaelsson, A.; Matsson, L. J. Immunol. Methods 1991, 145, $229-240$.

[233] Schneider, H. J.; Wang, M. J. Org. Chem. 1994, 59, 7464-7472.

[234] Lipskier, J. F.; Tranthi, T. H. Inorg. Chem. 1993, 32, 722-731.

[235] http://web.mit.edu/cortiz/www/afm.gif. jan-2006.

[236] Wiesendanger, R. Scanning Probe Microscopy and Spectroscopy; Cambridge University Press: New York, 1994.

[237] H.-Grant, M.; Lippard, S. J. Inorg. Synth. 1980, 20, 101.

[238] Anibale, G.; Brandolisio, M.; Pitteri, B. Polyhedron 1995, 14, 451-453.

[239] McDermott, J. X.; White, J. F.; Whitesides, G. M. J. Am. Chem. Soc. 1976, 98, 6521-6528. 


\section{Apêndice A}

\section{Supermoléculas com $\operatorname{Pt}(\text { tpy })^{2+}$ e $\operatorname{Pt}($ dcbpy $) \mathrm{Cl}^{+}$}

\section{A.1 Síntese do complexo $[\mathrm{Pt}(\mathrm{tpy}) \mathrm{Cl}] \mathrm{Cl}$}

O método convencional de síntese deste complexo envolve reação direta entre terpy e $\mathrm{K}_{2}\left[\mathrm{PtCl}_{4}\right]$ em água, com agitação e refluxo por pelo menos 24 horas [199,237]. Porém esse procedimento é moroso e o rendimento geralmente é baixo, devido a decomposição de parte do sal de platina empregado. A metodologia descrita abaixo, proposta por Annibale e col. [238], otimiza essa rota sintética substituindo os cloretos por um grupo abandonador melhor, o qual proporciona uma cinética de substituição mais rápida na reação do platinato complexo precursor com terpy. A síntese de $\left[\mathrm{Pt}(\mathrm{COD}) \mathrm{Cl}_{2}\right]$ foi realizada segundo a referência [239].

\section{A.1.1 Primeira etapa}

$200 \mathrm{mg}$ de $\mathrm{K}_{2} \mathrm{PtCl}_{4}(0,48 \mathrm{mmol})$ são dissolvidos em $8 \mathrm{~mL}$ de solução contendo $5 \mathrm{~mL}$ de ácido acético e $3 \mathrm{~mL}$ de água. Sobre esta solução adiciona-se $0,2 \mathrm{~mL}$ de 1,5-ciclooctadieno (COD) (1,6 mmol) e aquece-se a mistura sob agitação a $90^{\circ} \mathrm{C}$ por 30 minutos. Obtém-se ao final um precipitado branco-amarelado, o qual é lavado 
sucessivamente com porções de $4 \mathrm{~mL}$ de água, etanol, éter e após é seco sob vácuo. Rendimento: $89 \%$.

\section{A.1.2 Segunda etapa}

Sobre uma suspensão de $200 \mathrm{mg}\left[\mathrm{Pt}(\mathrm{COD}) \mathrm{Cl}_{2}\right](0,20 \mathrm{mmol})$ misturada em $12 \mathrm{~mL}$ de água, adiciona-se $124 \mathrm{mg}$ de terpy $(0,53 \mathrm{mmol})$. A mistura é aquecida a $40-50^{\circ} \mathrm{C} \mathrm{e}$ mantida sob agitação por 30-40 minutos. Obtém-se ao final uma solução vermelha e o produto é isolado pela rota-evaporação a baixa pressão. O produto final assim obtido é lavado com éter dietílico e seco sob vácuo. Rendimento: 86\%. Análise elementar: $\mathrm{PtC}_{15} \mathrm{H}_{11} \mathrm{~N}_{3} \mathrm{Cl}_{2} .2 \mathrm{H}_{2} \mathrm{O}$ (Exp.) Calc.: $\% \mathrm{C}=(33,6) 33,6 ; \% \mathrm{H}(2,6) 2,8 ; \% \mathrm{~N}(7,7) 7,9$. $\mathrm{RMN}^{1} \mathrm{H}: \mathrm{H} 3=7.84 \mathrm{ppm}(\mathrm{d}), \mathrm{H}^{\prime}=7.87 \mathrm{ppm}(\mathrm{d}), \mathrm{H} 4=8.05 \mathrm{ppm}(\mathrm{t}), \mathrm{H}^{\prime}=8.12 \mathrm{ppm}$ (t), $\mathrm{H} 5=7.37 \mathrm{ppm}(\mathrm{t}), \mathrm{H} 6=7.81 \mathrm{ppm}(\mathrm{t})$.<smiles></smiles>

Figura A.1: Estrutura do complexo $[\mathrm{Pt}(\mathrm{tpy}) \mathrm{Cl}] \mathrm{Cl}$ com indicação das atribuições de ${ }^{1} \mathrm{H}$ RMN.

\section{A.2 Síntese do complexo $\left[\mathrm{Pt}(\mathrm{dcbpy}) \mathrm{Cl}_{2}\right]$}

A síntese do complexo $\left[\mathrm{Pt}(\mathrm{dcbpy}) \mathrm{Cl}_{2}\right]$ foi realizada segundo a referência [172] e está descrita abaixo.

$200 \mathrm{mg}$ de dcbipy $(0,82 \mathrm{mmol})$ são dissolvidos lentamente em $35 \mathrm{~mL}$ de água pela adição gradual de $\mathrm{KOH} 0,1 \mathrm{~mol} \cdot \mathrm{dm}^{-3}$, cuidando-se para manter o $\mathrm{pH} \leq 8,0$. A essa mistura adiciona-se $323 \mathrm{mg}$ de $\mathrm{K}_{2} \mathrm{PtCl}_{4}(0,78 \mathrm{mmol})$ mais $200 \mathrm{mg}$ de $\mathrm{KCl}$. O meio reacional é mantido sob refluxo e agitação por 4 horas e depois refrigerado a t.a. O produto é 
isolado do meio por precipitação com $\mathrm{HCl} 0,1 \mathrm{~mol} \cdot \mathrm{dm}^{-3}$. Esse precipitado é filtrado e lavado com água. Segundo a referência literária, o complexo $\left[\mathrm{Pt}(\mathrm{dcbpy}) \mathrm{Cl}_{2}\right]$ tem cor amarela e é purificado em coluna com sephadex LH20. Porém, esse método de purificação não se mostrou efetivo em nosso caso e testamos a síntese da supermolécula empregando o produto tal como obtido após secagem sob vácuo.

\section{A.3 Síntese da supermolécula $\left\{4-\mathrm{TPyP}[\mathrm{Pt}(\mathrm{tpy}) \mathrm{Cl}]_{4}\right\}^{8+}$}

Sobre uma solução contendo $20 \mathrm{mg}$ de 4-TPyP (0,032 mmol) dissolvida em $6 \mathrm{~mL}$ de TFE adiciona-se $72 \mathrm{mg}$ de $[\mathrm{Pt}($ terpy $) \mathrm{Cl}] \mathrm{Cl}(0,134 \mathrm{mmol})$. A seguir deixa-se agitar por 32 horas, alternando entre t.a. e aquecimento a $40-50^{\circ} \mathrm{C}$. Remove-se o solvente por rotaevaporação a baixa pressão, adiciona-se $10 \mathrm{~mL}$ de TFE e sobre esta solução verte-se $4 \mathrm{~mL}$ de $\mathrm{MeOH}$ contendo $100 \mathrm{mg}$ de $\mathrm{NH}_{4} \mathrm{PF}_{6}$ (0,61 mmol). Agita-se por 10 a 20 minutos. Procede-se em seguida nova rotaevaporação do solvente e lava-se o precipitado com água para remover o excesso de [Pt(terpy) $\mathrm{Cl}] \mathrm{Cl}$. O produto final, de coloração marrom-avermelhada é seco sob vácuo. Rendimento: 80\%. Análise elementar: $\left[\left(\mathrm{C}_{40} \mathrm{H}_{26} \mathrm{~N}_{8}\right)\left(\mathrm{PtC}_{15} \mathrm{H}_{11} \mathrm{~N}_{3}\right)_{4}\right]\left(\mathrm{PF}_{6}\right)_{8} \cdot 6 \mathrm{H}_{2} \mathrm{O}$ (Exp.) Calc.: $\% \mathrm{C}=(32,0) 33,4 ; \% \mathrm{H}$ $(2,2) 2,3 ; \% \mathrm{~N}(7,8) 7,8$ (figura A.2).

\section{A.4 Síntese da supermolécula $\left\{3-\mathrm{TPyP}[\mathrm{Pt}(\mathrm{tpy}) \mathrm{Cl}]_{4}\right\}^{8+}$}

A supermolécula 3-TPt(terpy)TPyP é obtida pela mesma metodologia empregada para o caso anterior. O produto final é de coloração vermelho-marrom. Rendimento: 50\%. Análise elementar: $\left[\left(\mathrm{C}_{40} \mathrm{H}_{26} \mathrm{~N}_{8}\right)\left(\mathrm{PtC}_{15} \mathrm{H}_{11} \mathrm{~N}_{3}\right)_{4}\right]\left(\mathrm{PF}_{6}\right)_{8} \cdot 6 \mathrm{H}_{2} \mathrm{O}$ (Exp.) Calc.: \% $=(36,7) 33,4 ; \% \mathrm{H}(2,4) 2,3 ; \% \mathrm{~N}(8,3) 7,8$ (figura A.3).

Diferente do que se esperava, essas supermoléculas são pouco solúveis em água. Acredita-se que elas agreguem fortemente em meio aquoso, prejudicando a solvatação. Em relação à síntese, quando não foi empregadp $\left(\mathrm{PF}_{6}\right)^{-}$como contra-íon, tentan-se manter os ânions $\mathrm{Cl}^{-}$no produto final, não obteve-se êxito na síntese. Quando o 


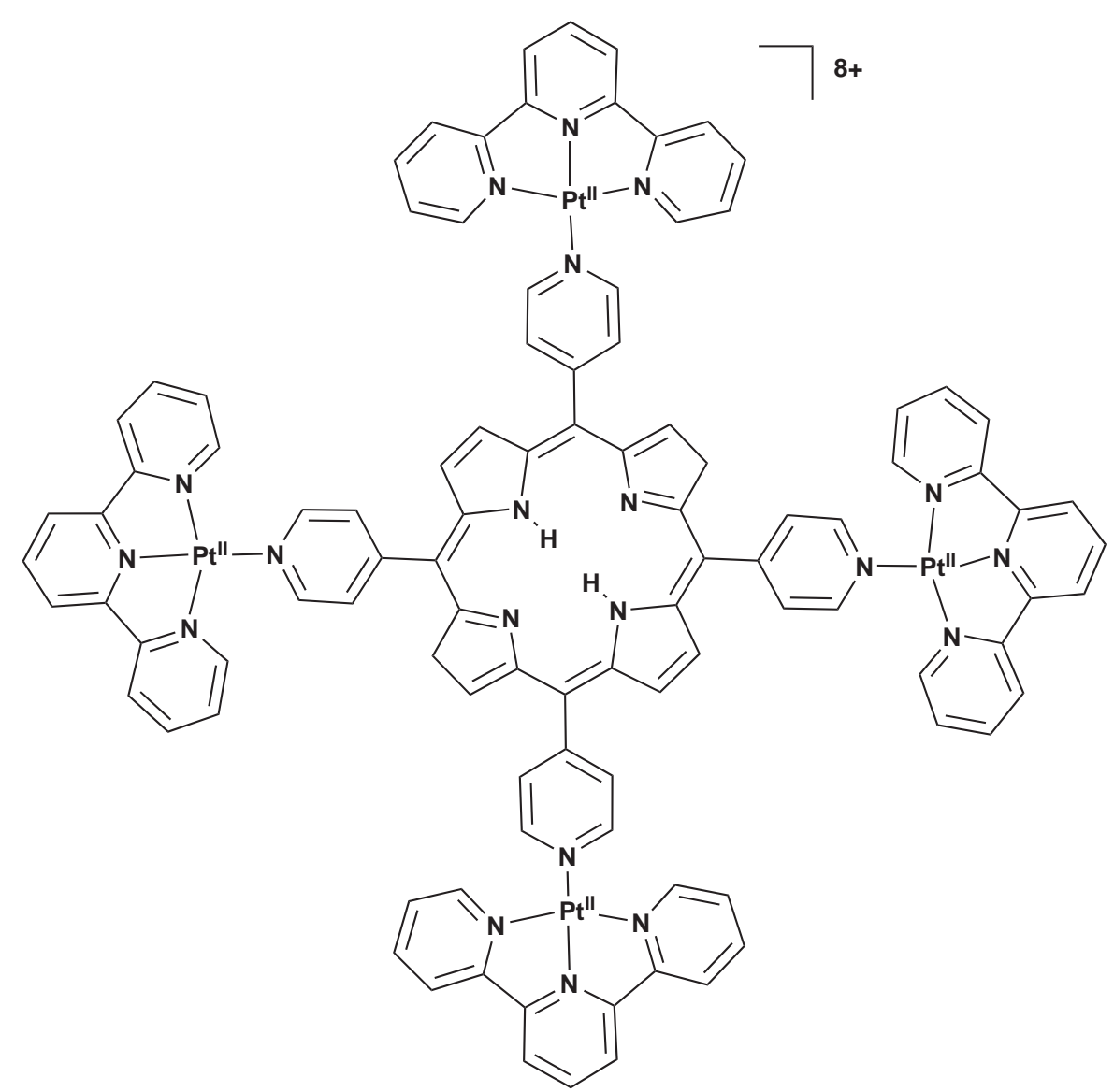

Figura A.2: Representação estrutural da supermolécula 4-TPt(terpy)TPyP. 


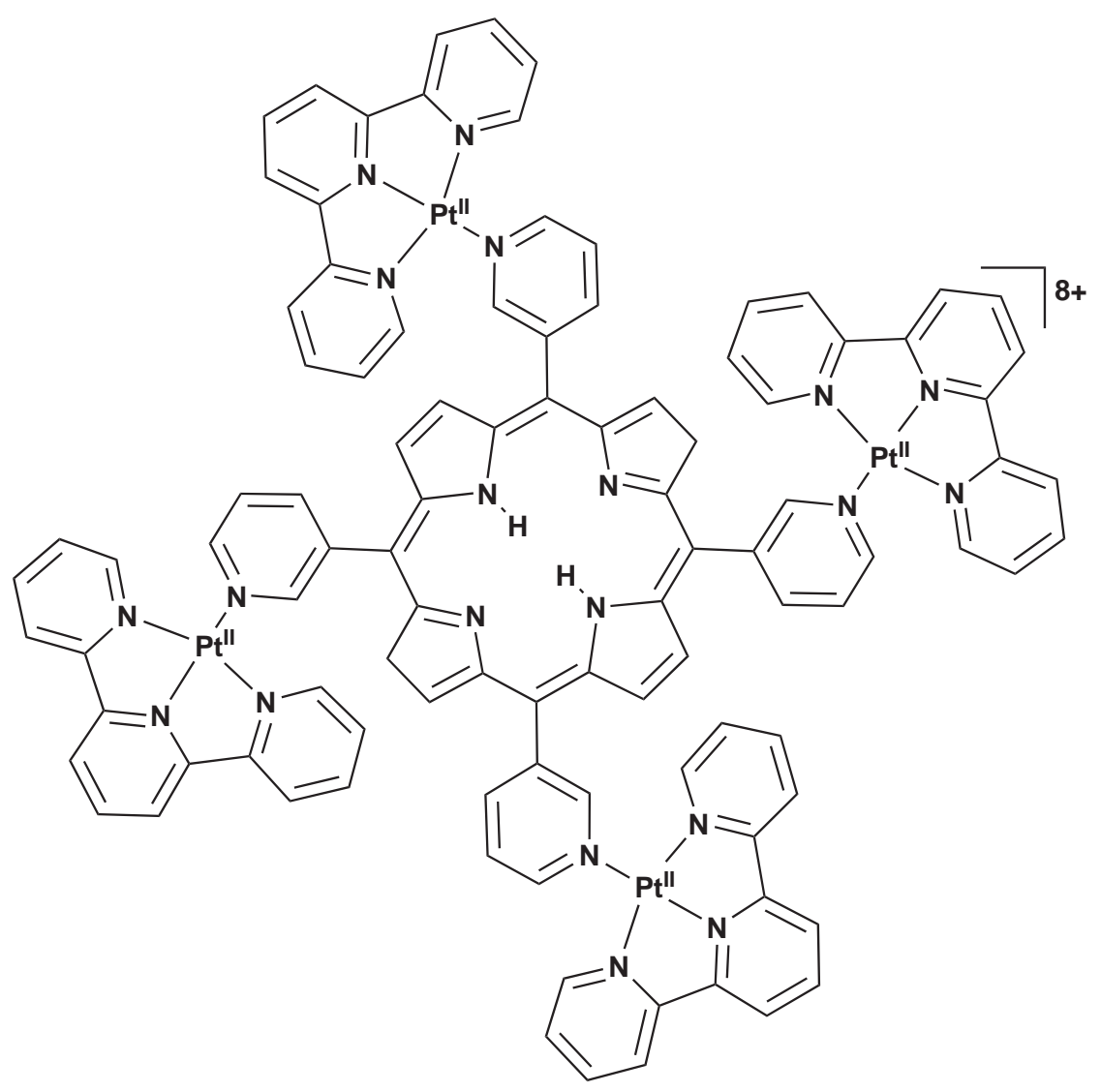

Figura A.3: Representação estrutural da supermolécula 3-TPt(terpy)TPyP. 
precipitado era lavado com água o complexo terpiridínico de platina era transferido completamente para a fase aquosa, restando apenas a porfirina no filtrado. Ou seja, a estabilização das cargas pelo uso de contra-íons de tamanho apropriado é o fator determinante na preparação dessas supermoléculas.

Outro problema vinculado às cargas dos complexos foi a impossibilidade de realizar a caracterização por ESI-MS. Nesse caso, o excesso de cargas torna o íon molecular $8+$ extremamente instável, de forma que ele entra em colapso tão logo seja transferido para a fase gasosa.

As figuras A.5 e A.4 trazem os espectros eletrônicos medidos em MeOH para a 3-TPtTPyP e TFE para a 4-TPtTPyP.

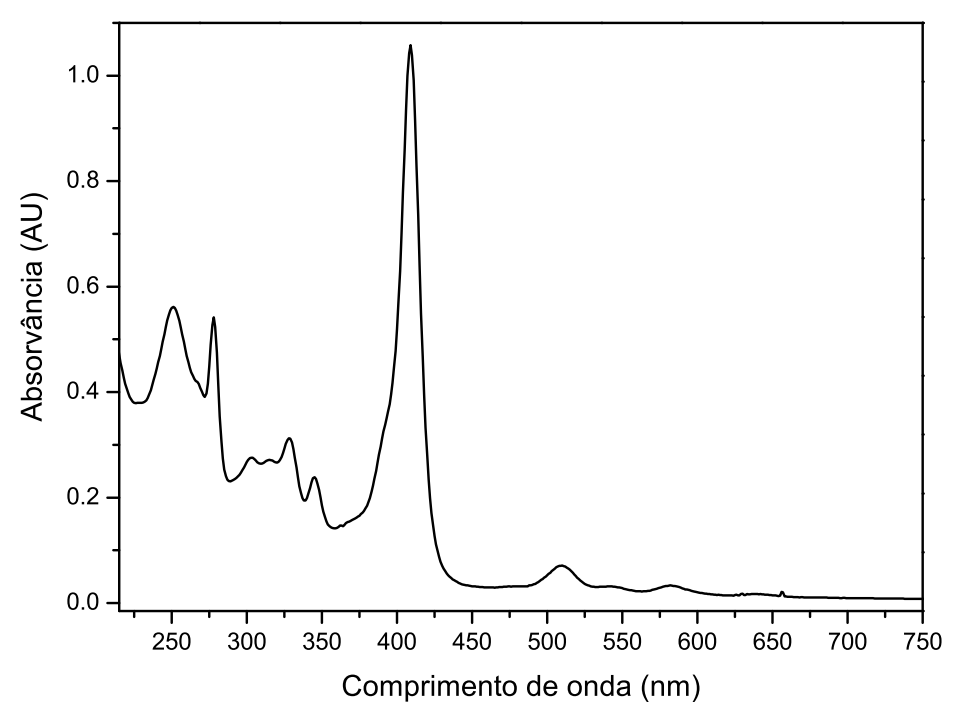

Figura A.4: Espectro eletrônico da 4-TPt(terpy)TPyP $4 \times 10^{-6} \mathrm{~mol} \cdot \mathrm{dm}^{-3}$ em TFE.

\section{A.5 Síntese da supermolécula $\left\{4-\mathrm{TPyP}[\mathrm{Pt}(\mathrm{dcbpy}) \mathrm{Cl}]_{4}\right\}^{4+}$}

Sobre uma mistura contendo $34 \mathrm{mg}$ de $\left[\mathrm{Pt}(\mathrm{dcbpy}) \mathrm{Cl}_{2}\right](0,067 \mathrm{mmol})$ em $15 \mathrm{~mL}$ de TFE é adicionado $20 \mathrm{mg}$ de KOH. Agita-se o sistema até a completa solubilização do complexo de partida e logo após acrescenta-se $10 \mathrm{mg}$ de 4-TPyP (0,016 mmol). O 


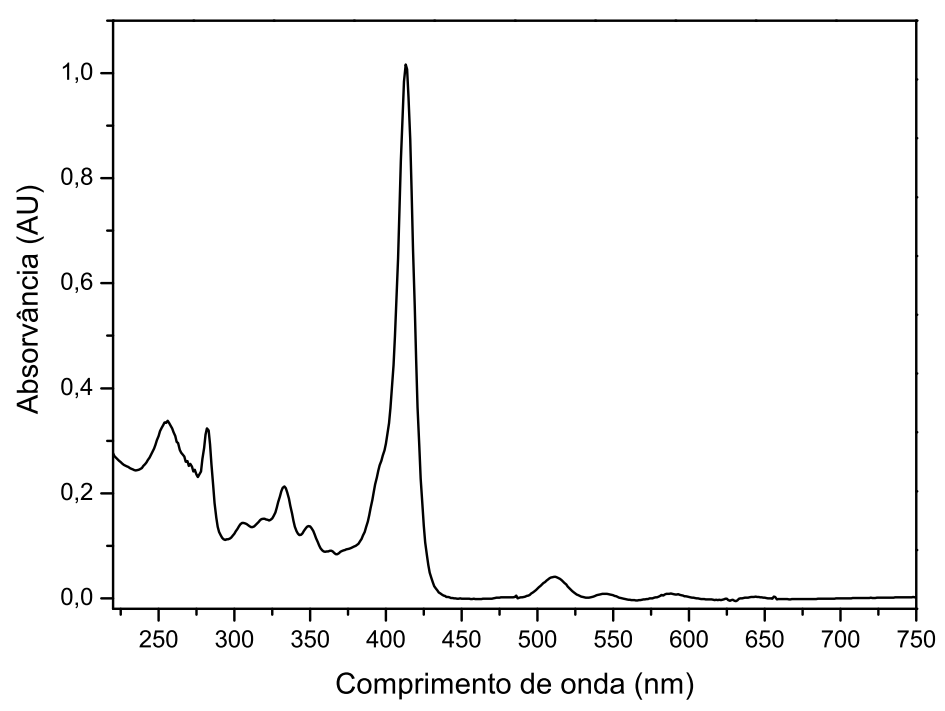

Figura A.5: Espectro eletrônico da 3-TPt(terpy)TPyP 4x10 $0^{-6} \mathrm{~mol} \cdot \mathrm{dm}^{-3} \mathrm{em} \mathrm{MeOH}$. meio reacional é mantido sob agitação por 48 horas, alternando-se entre t.a. e aquecimento a $40-50^{\circ} \mathrm{C}$. Decorrido esse período o solvente é removido por rota-evaporação sob baixa pressão. O precipitado é transferido para um tubo de vidro e onde é adicionado água/etanol 1:1. A suspensão formada é centrifugada por 15 minutos e depois o solvente é removido. Esse procedimento é repetido mais uma vez e logo após seca-se o produto sob vácuo por pelo menos 24 horas. Rendimento: $60 \%$. Análise elementar: $\left[\left(\mathrm{C}_{40} \mathrm{H}_{26} \mathrm{~N}_{8}\right)\left(\mathrm{PtC}_{12} \mathrm{H}_{8} \mathrm{~N}_{2} \mathrm{O}_{4} \mathrm{Cl}\right)_{4}\right] \mathrm{Cl}_{4} \cdot 10 \mathrm{H}_{2} \mathrm{O}$ (Exp.) Calc.: \%C $=(33,6) 37,2 ; \% \mathrm{H}(3,0)$ 2,$8 ; \% \mathrm{~N}(7,0) 7,9$ (figura A.6).

A figura A.7 apresenta o espectro UV/VIS desta espécie medido em meio aquoso básico. 


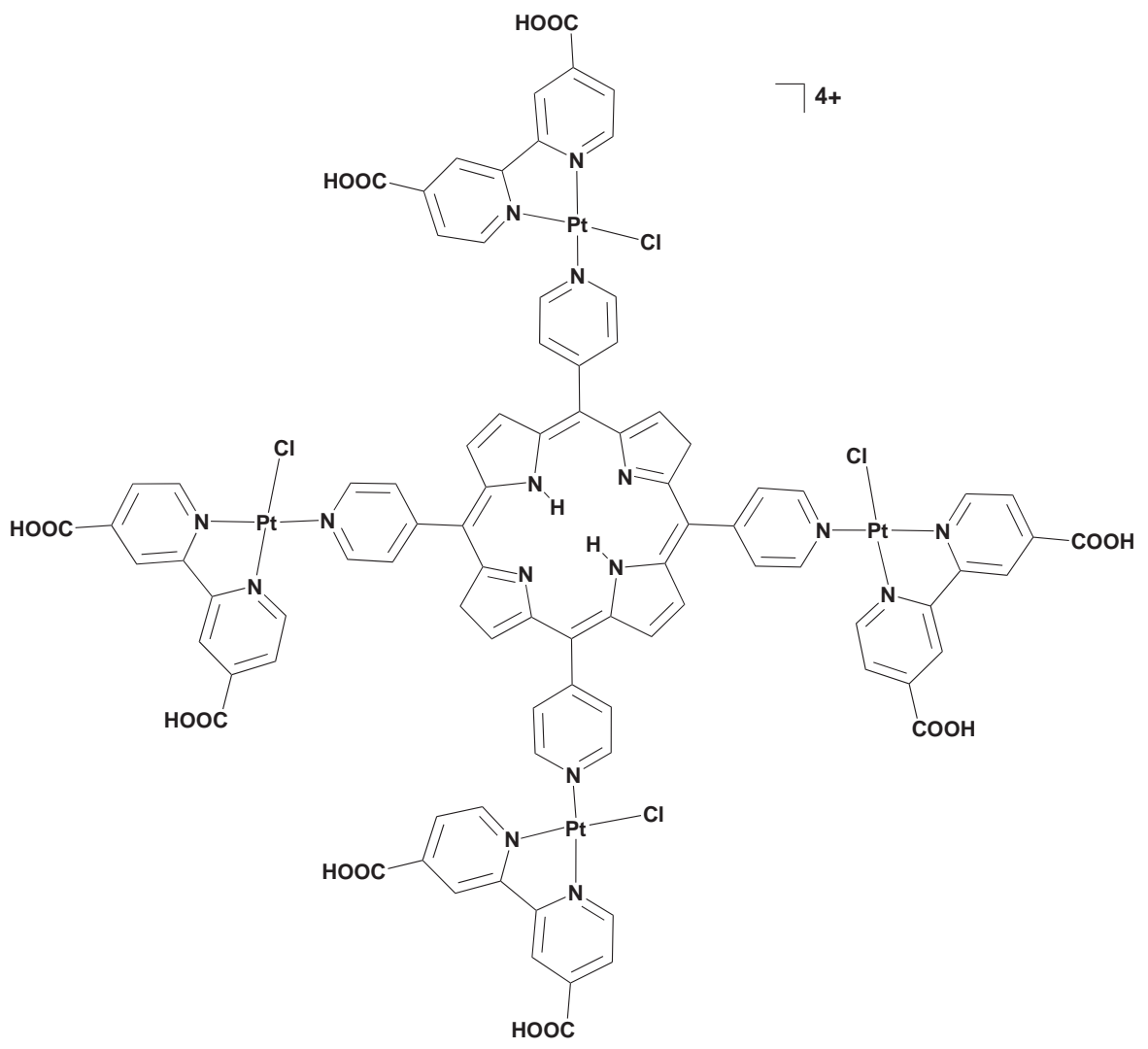

Figura A.6: Representação estrutural da supermolécula 4-TPt(dcbipy)TPyP

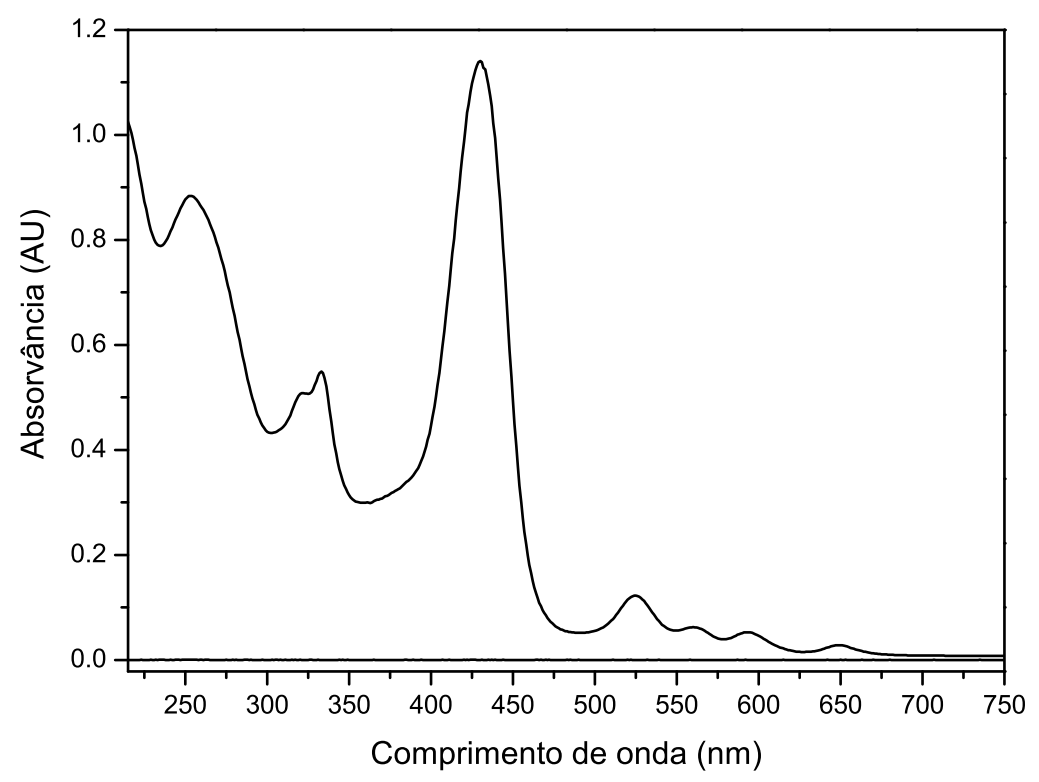

Figura A.7: Espectro eletrônico da 3-TPt(dcbpy)TPyP $6 \times 10^{-6} \mathrm{~mol} \cdot \mathrm{dm}^{-3}$ em solução aquosa de $\mathrm{NaOH} 5 \mathrm{mM}$. 


\section{Apêndice B}

\section{Curriculum Vitae do Autor}

DAdos Pessoais

Jeferson André Naue, casado, 29 anos.

Nascido em São Miguel d'Oeste - SC em 09/09/1976.

FORMAÇÃO ACADÊMICA

Doutorado em Química, Instituto de Química, Universidade de São Paulo, 2006.

Mestrado em Química, Universidade Federal de Santa Maria, 2001.

Graduação em Química Industrial, 1999 e Química - Licenciatura Plena, 2001, Universidade Federal de Santa Maria.

AtuaÇÃo Profissional

Coordenador de Pesquisa e Desenvolvimento, Novelprint Sistemas de Etiquetagem Ltda, São Paulo, SP, 08/2006 até o presente.

Químico de Aplicações em Espectroscopia Vibracional, Charis Technologies, São Paulo, SP, 02/2005 a 07/2006.

Professor Substituto, Universidade Federal de Santa Maria, Santa Maria, RS, 08/2000 a 01/2001. 


\section{PUBLICAÇÕES}

\section{Comunicações em Congressos}

22 comunicações, das quais são destacadas as cinco mais recentes:

1) Naue, J. A., Formiga, A. L. B., Nakamura, M., Toma, H. E., SFM Investigation of Supramolecular Tetrapyridilporphyrins Associated with four Peripheral Platinum(II) Complexes In: III Latin American Symposium on Scanning Probe Microscopy, Ouro Preto - MG. Third Latin American Symposium on Scanning Probe Microscopy - III LASPM - CD com resumos, 2005. p.87.

2) Naue, J. A., Formiga, A. L. B., Uemi, M., Toma, H. E., Modelagem Molecular e RMN ${ }^{195} \mathrm{Pt}$ de Tetrapiridilporfirinas Tetracoordenadas com Platina(II)-bipiridina In: $28^{\text {a }}$ Reunião Anual da Sociedade Brasileira de Química, Poços de Caldas, MG. Livro de Resumos, 2005. QI75.

3) Naue, J. A., Formiga, A. L. B., Nakamura, M., Toma, H. E., Ion Pair Associated Complexes Formed From Cationic Polymetallated Tetrapyridilporphyrins and Anionic Phthalocyanine In: XII Brazilian Meeting on Inorganic Chemistry - II Joint Brazilian/Italian Meeting on Inorganic Chemistry, São Carlos - SP. Program and Abstracts. , 2004. p.207

4) Naue, J. A., Formiga, A. L. B., Nakamura, M., Toma, H. E., Estudo Espectroscópico e Microscopia de Força Atômica de Dois Novos Complexos de Tetrapiridilporfirina-Platina(II) In: XXVI Congresso Latinoamericano de Química / 27 Reunião Anual da Sociedade Brasileira de Química, 2004, Salvador. Livro de Resumos. Sociedade Brasileira de Química, 2004. QI17

5) Naue, J. A., Formiga, A.L.B., Toma, H.E., Espectroscopia, Eletroquímica e Correlações Teóricas de uma Tetrapirazilporfirazina In: XII Encontro de Química da Região Sul, Guarapuava- PR. Livro de Resumos. 2004. QI08 


\section{Artigos}

1) Naue, J. A., Formiga, A. L .B., Nakamura, M., Tomazela, D., Eberlin, M. N., Toma, H. E. Synthesis, Spectroscopic, Electrochemical, Spectroelectrochemical, ESIMS and SPM Investigations of New Supramolecular Tetrapyridilporphyrins Modified with four Platinum(II) Complexes. Supramolecular Chemistry, 2006, submitted.

2) Naue, J. A., Bonacin, J. A., Toma, S. H., Toma, H. E, Enhanced DNA Binding Properties of a Tetraplatinated Tetrapyridilporphyrin Complex. Journal of Inorganic Biochemistry, 2006, submitted.

3) Hörner, M., de Oliveira, G.M., Naue, J. A., Beck, J., Polymeric assembling through reciprocal metal- $\eta^{2}$-arene $\pi$-interactions: Synthesis and X-ray characterization of $\left[\mathrm{Hg}(\mathrm{II})\left(\mathrm{RPhNNNPhR}^{\prime}\right)_{2} \mathrm{Py}\right]_{2}\left(\mathrm{R}=\mathrm{NO}_{2}, \mathrm{R}^{\prime}=\mathrm{F}\right)$, an asymmetric bis diarylsubstituted triazenidepyridinyl complex of $\mathrm{Hg}(\mathrm{II})$, Journal of Organometallic Chemistry, 691, 1051-1054, 2006.

4) Bonacorso, H. G., Wastowski, A. D., Zanatta, N., Martins, M. A. P., Naue, J. A., Haloacetylated enol ethers 10. Condensation of B-alkoxyvinyl trifluoromethyl ketones with thiosemicarbazide. Synthesis of new trifluoromethyl 4,5-dihydro-1H-1pyrazolethiocarboxyamides. Journal Of Fluorine Chemistry, 92, 23-26, 1998. 